\title{
CONTABILIDADE RURAL: UM ENFOQUE GERENCIAL
}

\author{
MARIA RAQUEL SIMOES MONTEIRO DOS SANTOS
}

Engenheiro Agrônomo

Orientadora: Profa. Dra. Zilda Paes de Barros Mattos

Dissertação apresentada à Escola Superior de Agricultura "Luiz de Queiroz", da Universidade de São Paulo, para obtenção do título de Mestre em Agronomia, Area de Concentração: Economia Agrária.

\author{
PIRACICABA \\ Estado de São Paulo \\ Janeiro - 1991
}




\section{CONTABILIDADE RURAL: UM ENFOQUE GERENCIAL}

MARIA RAQUEL SIMOES MONTEIRO DOS SANTOS

Aprovada em: 10.junho.1991

Comissão Julgadora:

Profa. Dra. Zilda Paes de Barros Mattos ESALQ/USP

Prof. Dr. José Ferreira de Noronha ESALQ/USP

Dr. Flávio Condé de Carvalho IEA/SAA

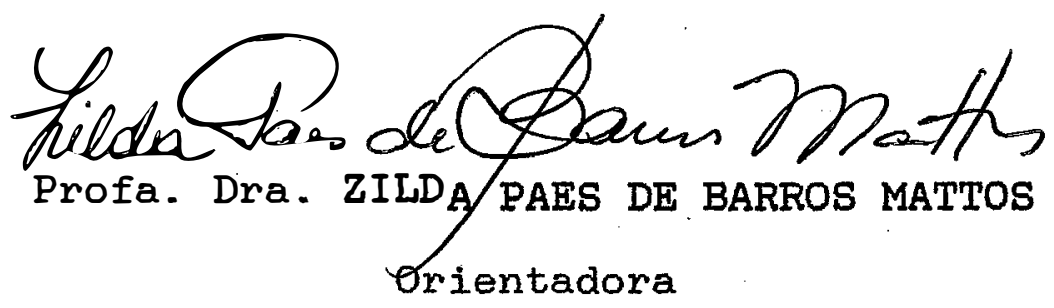


Ao meu pai.

A minha mãe, invisivel presença silenciosa. 
AGRADECIMENTOS

A Professora Zilda Paes de Barros Mattos, que em dedicada tarefa de orientar, foi confiante, compreensiva e amiga, em. todos os momentos.

Ao Professor José Ferreira de Noronha, que com sugestões sempre bem-vindas, incentivou o desenvolvimento deste trabalho.

Aos Professores Fernando Curi Peres e Flávio Condé de Carvalho, pelas valiosas criticas apresentadas.

Ao Professor Sydney C. James do Departamento de Economia da Brigham Young University, de Utah, E.U.A., pela paciente leitura e criteriosas observações.

A Renato Guerrini Neto, pelo bem elaborado trabalho de programąão de computadores.

Ao Sr. Marcus Vinicius Fittipaldi, pela oportuna colaboração.

Aos Professores e Funcionários do Departamento de Economia e Sociologia Rural e da Seção de Pós-Graduação da ESALQ, cuja postura solidária foi sempre favorável à conclusão desta pesquisa.

Ao CNPQ, CAPES e Fundação W.K.KELLOGG, pelo suporte financeiro. 
LISTA DE FIGURAS......................... v

LISTA DE TABELAS........................... vi

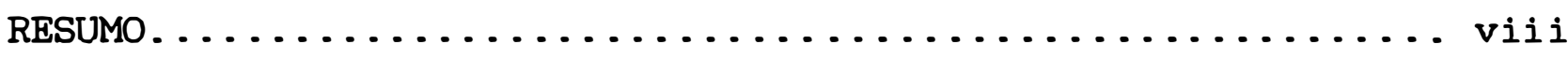

SUMMARY $\ldots \ldots \ldots \ldots \ldots \ldots \ldots \ldots \ldots \ldots \ldots \ldots \ldots \ldots \ldots \ldots \ldots \ldots \ldots$

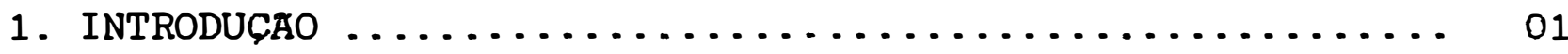

1.1. A Contabilidade Rural .................... 01

1.2. O Problema .......................... 08

1.3. Objetivos .......................... 21

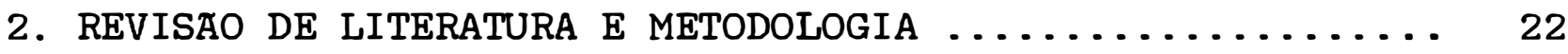

2.1. Informaç̃̃es Geradas pelo Sistema Contábil ........ 22

2.2. Elementos Básicos de um Sistema Contábil ........ 46

3. RESULTADOS E DISCUSSAO........................ 65

3.1. Informaç̃es Geradas pelo Sistema Contábil ........ 65

3.2. Elementos Básicos do Sistema Contábil .......... 135

3.3. O Teste do Modelo Proposto ................. 181

4. CONCLUSOES E RECOMENDACOES................... 268

REFERENCIAS BIBLIOGRAFICAS $\ldots \ldots \ldots \ldots \ldots \ldots \ldots \ldots \ldots \ldots \ldots \ldots \ldots \ldots \ldots$ 


\section{LISTA DE FIGURAS}

Título

Página

1. Utilização da Contabilidade no processo de gerência ...... 02

2. O sistema de informacão e o sistema empresa ............ 04

3. o periodo contábil ......................... 49

4. Coordenação dos demonstrativos: Balanco Patrimonial, Demonstração do Resultado do Exercicio e Fluxo de Caixa... 116

5. Modelo Proposto de Razonete ...................... 169

6. Transcricões nos Razonetes ......................... . 232

7. Ajustes ................................ 241

8. Encerramento de Contas e Distribuição dos Resultados .... 245 


\section{LISTA DE TABELAS}

Titulo

Página

1. Proposta de taxąão da renda agricola, $1988 \ldots \ldots \ldots \ldots \ldots .16$

2. Imposto de Renda da Atividade Rural, 1991 ............ 18

3. Formas de Apurą̧̃o do Resultado da Atividade Rural,1991.. 18

4. Modelo Proposto de Balanco Patrimonial .............. 66

5. Modelo Proposto de Demonstracão do Resultado do Exercicio da Empresa e das Atividades Agropecuárias ........... 85

6. Modelo Proposto de Fluxo de Caixa .................. 111

7. Modelo Proposto de Ficha de Estoque ................ 125

8. Relatório Emitido pelo Programa "DEPRECIA" - Relação de Dados .................................. 133

9. Relatório Emitido pelo Programa "DEPRECIA" - Depreciacão

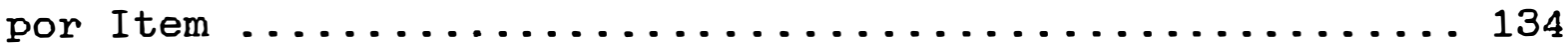

10. Elenco de Contas Simplificado .................. 143

11. Sub-Elenco de Contas das Atividades Produtivas ......... 154

12. Mecanismo de Débito e Crédito do Método das Partidas Dobradas ................................ 163

13. Modelo Proposto de Livro Diário .................. 166

14. Modelo Proposto de Livro Razão ................... 168

15. Modelo Proposto de Balancete de Verificąão .......... 172

16. Inventário Periódico ....................... 184

17. Ficha de Estoque $\ldots \ldots \ldots \ldots \ldots \ldots \ldots \ldots \ldots \ldots \ldots \ldots$

18. Ficha de Estoque $\ldots \ldots \ldots \ldots \ldots \ldots \ldots \ldots \ldots \ldots \ldots \ldots \ldots \ldots$

19. Ficha de Estoque ........................ 187 (continua) 
LISTA DE TABELAS (continuacão)

Título

Página

20. Controle de Ativo Imobilizado - Relação de Dados ........ 189

21: Controle de Ativo Imobilizado - Reląão de Dados ........ 190

22. Controle de Ativo Imobilizado - Relação de Dados ........ 191

23. Controle de Ativo Imobilizado - Depreciacão por Item .... 192

24. Controle de Ativo Imobilizado - Depreciacão por Item .... 193

25. Controle de Ativo Imobilizado - Depreciacão por Item .... 194

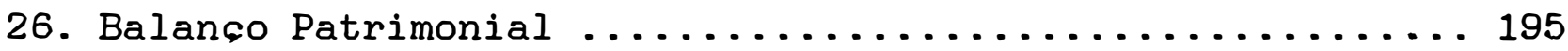

27. Sub-Elenco de Contas das Atividades Produtivas ........ 198

28. Elenco de Contas Completo ....................... 199

29. Livro Diário .......................... 223

30. Livro Caixa ........................... 230

31. Inventário Periódico ..................... 239

32. Balanco Patrimonial ...................... 257

33. Demonstracão do Resultado do Exercicio da Empresa e das Atividades Produtivas ...................... 260

34. Fluxo de Caixa .......................... 264 
CONTABILIDADE RURAL: UM ENFOQUE GERENCIAL

Autora: MARIA RAQUEL SIMOES MONTEIRO DOS SANTOS Orientadora: PROFa. DRa. ZILDA PAES DE BARROS MATTOS

RESUMO

Este trabalho tem como objetivo primordial o desenvolvimento de uma tecnologia voltada às necessidades gerenciais da empresa agropecuária brasileira: um Modelo de Contabilidade Rural.

O roteiro seguido tem como etapa inicial uma revisão critica dos principais modelos de Contabilidade Rural, existentes no Brasil e no exterior, avaliando a funcionalidade desses sistemas, sob a ótica gerencial. Com essa abordagem são analisadas as principais informações geradas, os procedimentos metodológicos adotados e conferido o uso de principios e convencões contábeis, na tentativa de se produzir um material didático, que esclareça algumas questões pendentes sobre o assunto.

Nesse processo foi possivel constatar que, até o presente momento, a empresa rural brasileira não conta com o apoio de um sistema contábil eficiente, enquanto gerador de 
informacões úteis às tomadas de decisões. Dentre os diferentes modelos revisados, com destaque para o trabalho pioneiro de MARION (1985a, 1985b, 1986), surgiu uma lacuna significativa, à medida que a atual crise econômica vem exigindo soluções para maior competitividade do setor agricola.

O resultado constituiu-se na proposicão de um Modelo que, conservando a estrutura já consagrada pela "Contabilidade Tradicional", incorporou conceitos fundamentais à análise econômica das atividades agropecuárias e elementos necessários à produção de informacões-gerenciais confiáveis, dentro de um contexto inflacionário.

Um teste manual simplificado, com dados de uma pequena empresa rural, tentou demonstrar que o sistema proposto atende aos objetivos especificos deste trabalho e é suficientemente flexivel, para ser implementado em diferentes situações.

Reconhece-se, no entanto, que o Modelo apresenta, ainda, um certo grau de complexidade para seus usuários finais, particularmente o médio empresário rural. Entretanto, com a elaboracão do "software", na segunda etapa deste projeto, acredita-se que essa nova metodologia possa ser difundida, de modo mais rápido e prático, entre os profissionais atuantes na área. Espera-se, também, que venha despertar o interesse da classe produtora e servir como referencia para futuras pesquisas em Administração Rural. 
AGRICULTURAL ACCOUNTING: A MANAGERIAL APPROACH

Author: MARIA RAQUEL SIMOES MONTEIRO DOS SANTOS

Advisor: Prof. Dr. ZILDA PAES DE BARROS MATTOS

\section{SUMMARY}

The main objective of this study was to develop a technology oriented towards managerial needs of the Brazilian agricultural firm: an Agricultural Accounting Model.

The procedure used to achieve that objective was a critical review of the main existing Agricultural Accounting models, Brazilian and foreigners, evaluated from the managerial point of view. The most important information generated, the methodological criteria adopted and the use of general accounting principles and conventions, were revised for each model, in an attempt to create an educational material which can hopefully shed some light on some of the most confusing points about the subject.

The results of the literature review showed that the Brazilian agricultural firm still does not have an efficient accounting system which can generate useful information for decision making. Among the models studied, including MARION's 
pioneer work (1985a, 1985b, 1986), a gap could be observed, which becomes more serious to the extent that the economic crisis is demanding greater efficiency from the agricultural sector.

The main result of the study was the development of an Agricultural Accounting Model which, while keeping the well known structure of the traditional Financial Accounting models, it added basic concepts to the economic analyses of the individual enterprises and necessary elements to the production of more precise managerial information, under inflationary condition.

A manual test of the proposed model, at the farm level, showed that the proposed system is consistent with the specific objectives of this study and that it is flexible enough to be used in diferent situations.

However, it is recognized that the model, as it is, still presents a certain degree of complexity for the user, specially the medium farmer. Neverthless, one believes that with the software, to be developed in a second phase of this project, this methodology can be disseminated among agricultural firms, in a faster and more practical way. It is also hoped that this study will stimulate farmers interest and be used as reference to future research in this area of Farm Management. 


\section{INTRODUÇAO}

\subsection{A Contabilidade Rural}

o processo de expansão e modernização da agricultura brasileira tem exigido da empresa rural uma maior abertura às tecnologias gerenciais, no sentido de se alcançar niveis mais altos de eficiência e eficácia.

A empresa rural, como um sistema aberto, está sujeita permanentemente às pressões do ambiente externo traduzidas na forma de continuas alterações da conjuntura sócio-politicoeconômica. Sua capacidade de resposta às exigências ambientais é uma função direta dos processos decisórios. Estes, por sua vez, dependem de um sistema que produza informações confiáveis, internas e externas, em tempo hábil (BIO, 1985).

Assim, o êxito da empresa rural em responder satisfatoriamente à modernização da agricultura está condicionado a seu nível de eficiência na condução dos métodos produtivos com o emprego de instrumental administrativo adequado.

Nesse contexto se insere o Sistema de Informacão como um subsistema da empresa responsável pelo tratamento de dados básicos, gerando informações que apoiam as decisões administrativas no ciclo planejamento - direção - execucão controle.

Tal sistema é constituído por um conjunto de elementos integrados (subsistemas) abrangendo as diferentes etapas do processo de gerência e em continua interação com o meio ambiente, 
conforme esquematizado na Figurg 1. As tomadas de decisões influenciam e são influenciadas pela qualidade do Sistema de Informacão, afetando a sobrevivência e o crescimento da empresa.

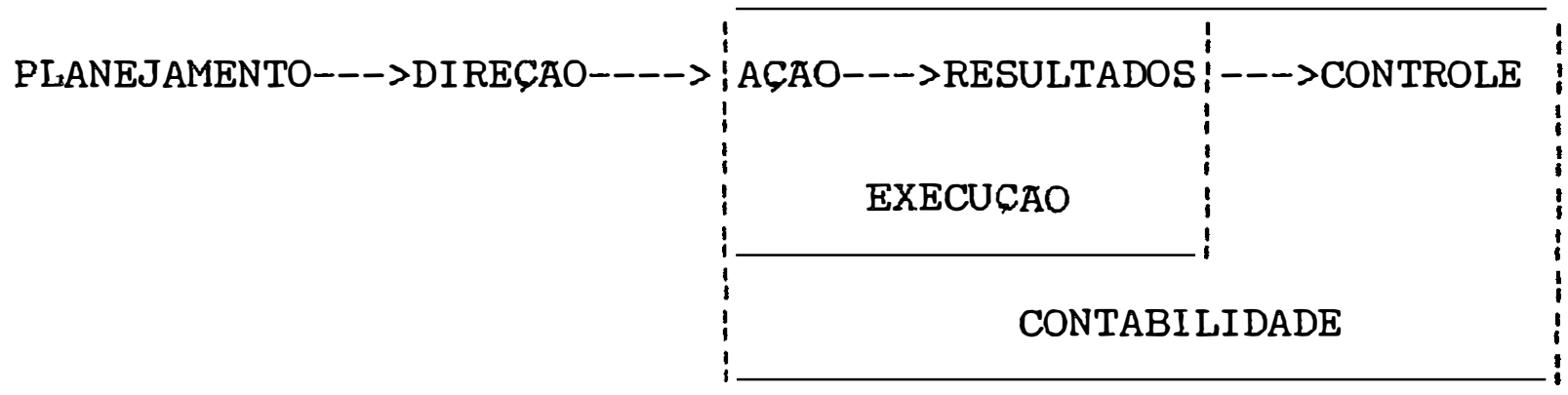

Figura 1. Utilização da Contabilidade no processo de gerência. Fonte: BIO (1985).

A Contabilidade ou Sistema Contábil representa um dos componentes do subsistema de informacões internas que atua como instrumento de operacão e controle da empresa.

Por outro lado, a Contabilidade pode ser definida como uma ciência que combina fundamentos econômicos, matemáticos e até sociais com a finalidade de captar, registrar, acumular, resumir e interpretar os fenômenos que afetam as situações patrimoniais, financeiras e econômicas da entidade (IUDICIBUS et alii, 1983).

A unidade de producão agropecuária ou "empresa rural", como qualquer outra unidade produtiva sujeita a estimulos de mercado, necessita da administracão como uma forma de racionalizar tanto a alocacão dos recursos, como a gestão dos recursos já alocados, para maximização dos lucros continuamente 
através dos anos.

O produtor ou empresário rural, assim como empresários de outros setores da atividade econômica, enfrenta também problemas administrativos, carecendo de um instrumental que oriente suas tomadas de decisões ao longo do processo de gerência.

No entanto, a empresa rural exibe caracteristicas bem especificas que a diferenciam das empresas de outros setores. A estacionalidade da producão agropecuária, as peculiaridades de seus processos produtivos, a complexidade de sua estrutura organizacional, a multiplicidade de seus objetivos, os altos graus de riscos diretos e indiretos são apenas algumas das particularidades que devem ser levadas em conta na geracão de tecnologias gerenciais próprias para o setor agropecuário (ALBUQUERQUE, 1985; NORONHA, 1987 ).

A Contabilidade Rural se impõe como um dos ramos da Contabilidade Geral capaz de informar, controlar e analisar a empresa rural quaisquer que sejam suas atividades e peculiaridades. Ela não esgota todas as informações necessárias às tomadas de decisões, mas é uma fonte decisiva de dados quantitativos e qualitativos, reduzindo o risco e a incerteza inerentes ao processo decisório.

Como parte integrante do Sistema de Informação da empresa, a Contabilidade Rural é desenvolvida em um ciclo de coleta e processamento de dados que culmina com a producão e distribuicão de informações de saida, na forma de relatórios 
contábeis. Os relatórios garantem à gerência um fluxo continuo de informacões sobre os mais variados aspectos econômicos e financeiros da empresa, permitindo a avaliação de sua situacão atual e comparações com o que foi planejado. Esse confronto fornece subsidios à identificacão e controle dos desvios e suas causas, bem como auxilia o aperfeicoamento de futuros planejamentos (Figura 2).

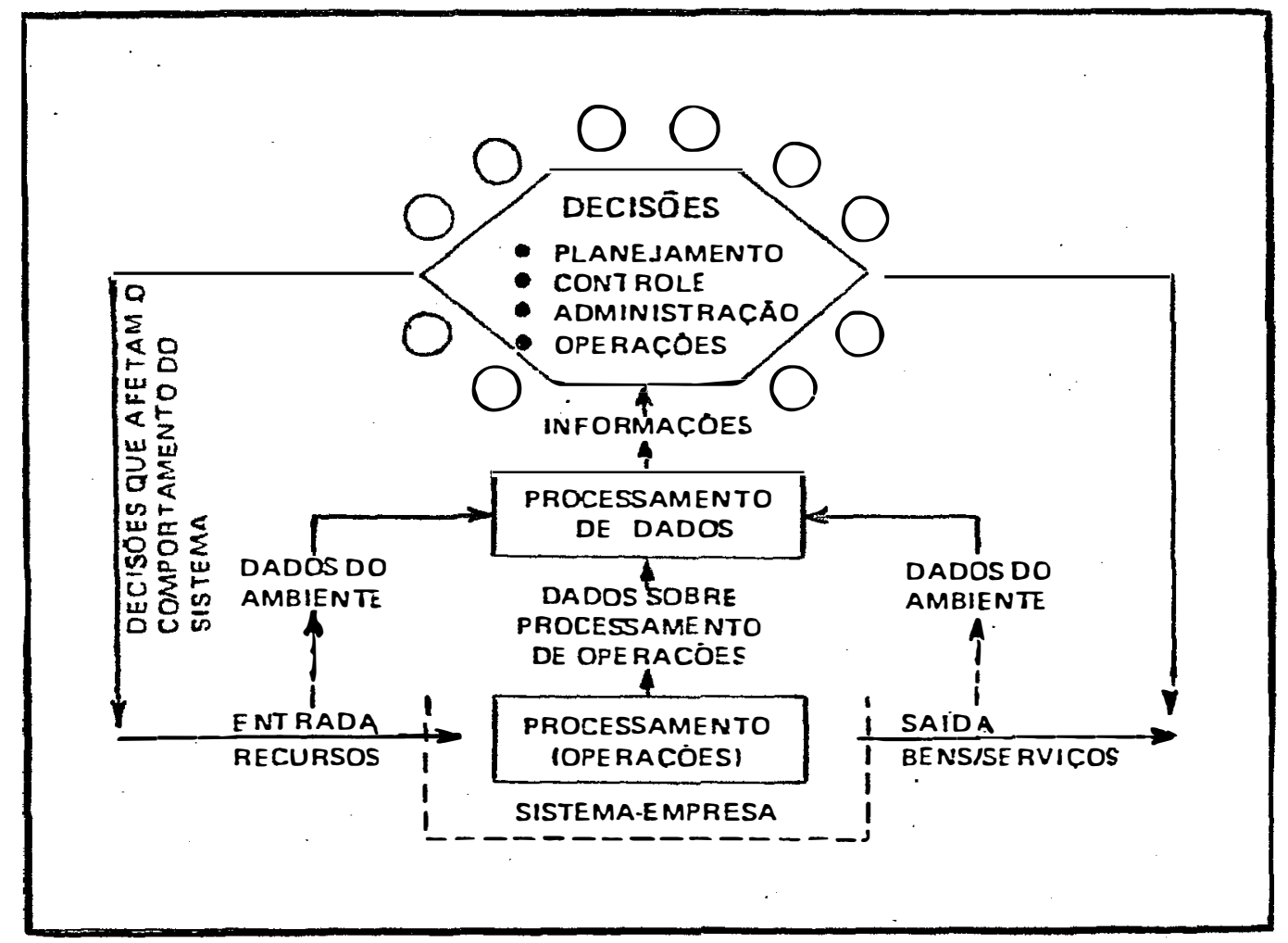

Figura 2. O sistema de informação e o sistema empresa. Fonte: BIO (1985).

Um sistema contábil eficiente, aliado ao bom senso do administrador em usar as informações, permite um diagnóstico realista com a localização dos pontos fracos e fortes de cada atividade produtiva e da empresa como um todo. Na posse de tais informacões poderão ser derivadas inúmeras conclusões e interpretações para as seguintes finalidades (HOFFMANN et alii, 
1981; JAMES \& STONEBERG, 1980; NORONHA, 1987):

1 - orientar as operações de rotina;

2 - medir o desempenho econômico-financeiro da empresa e de cada atividade produtiva individualmente;

3 - controlar as transacões financeiras da empresa;

4 - fornecer subsidios para as tomadas de decisões no planejamento da producão, dos investimentos, das vendas, etc.;

5 - fornecer subsidios para as projecões de fluxos de caixa e necessidades de crédito;

6 - permitir a comparacão da performance da empresa no tempo e desta com outras empresas;

7 - conduzir as despesas pessoais do empresário (proprietário) e de sua familia;

8 - justificar a liquidez e capacidade de pagamento da empresa junto aos agentes financeiros e outros credores;

9 - servir de base para seguros, arrendamentos e outros contratos;

10 - gerar informações para a declaração do Imposto de Renda.

Ainda que o sistema contábil sirva de base para a apuração do Imposto de Renda, é como instrumento gerencial que ele proporciona ao empresário o lastro das informações necessárias à uma administração mais segura.

Cabe ressaltar que, como uma ciência basicamente 
quantitativa, a Contabilidade apresenta limitacões que devem ser consideradas para que seus resultados se conformem com 0 esperado. Em primeiro lugar, a Contabilidade não é um fim em si mesma, só tendo utilidade na medida em que serve de fonte de informações para uma gestão mais eficiente.

A eficiência com que o administrador pode usar e analisar as informacões contábeis é uma função direta de sua capacidade em compreender os principios, convencões e procedimentos que regem o funciönamento do sistema contábil e atribuem a ele diversas limitações, entre as quais podem-se destacar (FROGOLI, 1977; IUDICIBUS et alii, 1983):

a) os dados do sistema contábil são expressos, basicamente, $\therefore$ em termos monetários, refletindo apenas os fatos mensuráveis em moeda. Outros elementos que não podem ser convertidos em dinheiro não serão exibidos pelo sistema, por exemplo: o "know how" da empresa, a capacidade de sua administração, o grau de treinamento e especialização de seus recursos humanos, dados de origem externa como problemas econômicos, politicos e sociais, condiç̃es de competicão, modificações de leis e regulamentos, etc.;

b) os relatórios contábeis demonstram situações e ocorrências empresariais restritas a periodos limitados de tempo;

c) é impossivel determinar o grau de precisão dos relatórios contábeis porque são resultantes de processos selecionados entre várias alternativas, implementadas sob diferentes premissas e aplicados mediante julgamentos subjetivos; 
d) a aplicação de determinados "Principios e Convencões Contábeis Geralmente Aceitos" (item 2.2.8.) pode restringir a capacidade informativa dos relatórios contábeis pelo não reconhecimento das flutuações dos preços devidas à inflação (Principios do "Custo Histórico como Base de Valor", do "Denominador Comum Monetário", Convenção do "Conservadorismo");

e) os relatórios contábeis elaborados segundo delimitações de ordem fiscal e outras disposições de origem governamental, refletem uma realidade distorcida e suas informações não se prestam às finalidades gerenciais.

Antes mesmo das limitações, um fato a ser considerado é que qualquer sistema contábil, por menores que sejam suas restrições, somente será vantajoso na medida em que atender às necessidades da empresa a um custo compensador.

Essas limitações, entretanto, não invalidam o sistema contábil pois parte-se do pressuposto de que seu usuário adotará uma postura bem informada, prudente e critica tanto na sua adoção, quanto durante seu funcionamento e interpretação dos resultados. Além do mais "a utilidade e a eficácia de qualquer instrumento de análise são, via de regra, aumentadas à medida que o usuário se familiariza com ele..." (IUDICIBUS, 1982 p.21). 


\subsection{O Problema}

Embora seja evidente a importância da Contabilidade como instrumento gerencial, a sua adoção pelo meio rural brasileiro tem se mostrado insignificante, ainda que ultimamente comecem a surgir sinais de uma maior demanda.

A grosso modo, as empresas rurais brasileiras com todas as suas discrepâncias, têm algo em comum: a escassa ou nula utilização de técnicas administrativas modernas. Aliás, a Administração Rural tem sido até hoje um dos ramos das Ciências Sociais mais negligenciados tanto em termos de sua aplicacão, como em pesquisa e ensino, no Brasil.

Via de regra, a administração da empresa rural brasileira se desenvolve dentro de um padrão de desempenho inaceitável ou seguindo critérios bastante tradicionais. Essa característica não é atributo apenas dos minifúndios com economia de subsistência, prevalecendo também entre propriedades maiores, com economia de mercado e nivel de renda mais alto (ALBUQUERQUE, 1979; DELGADO, 1979).

Nesse contexto, a Contabilidade Rural se destaca como uma das técnicas administrativas que maior porcentagem de produtores deixa de realizar (SANTOS, 1982). Normalmente é encarada como uma técnica complexa que dispende muito tempo na sua realizacão, com baixo retorno na prática. Por outro lado, os poucos produtores rurais sujeitos à tributacão do Imposto de Renda relegam todo o servico contábil a escritórios de contabilidade, sem mostrar maiores interesses por uma aplicação 
gerencial (OLIVEIRA, 1979).

O uso dos recursos cientificos da Administracão, e mais especificamente da Contabilidade, no meio rural brasileiro não tem apresentado um desenvolvimento definido. 0 mesmo tem sido marcado pela falta de harmonia entre os interesses e necessidades da producão, extensão, pesquisa e ensino (FRANCO, 1984).

São inúmeros e complexos os fatores que têm contribuido para essa tendência desde o inicio do século, quando surgiram os primeiros esforcos em ensinar a Contabilidade Rural nos meios universitários.

Diversos autores levantaram hipóteses quanto às possiveis causas do insucesso da Contabilidade Rural no pais, como instrumento gerencial. Dentre elas, podem-se destacar e discutir:

a) falta de capacitacão instrumental e conceitual das universidades no ensino das disciplinas ligadas à Administracão Rural.

O estudo da Administração Rural no Brasil surgiu com a "Contabilidade Agrícola" como disciplina obrigatória nos cursos de Agronomia e Veterinária, durante a década de 20 (DELGADO 1979; FRANCO, 1984). Entretanto, desde essa época, tem se prendido mais aos aspectos didáticos, desprovido de quaisquer atividades de pesquisa, a não ser em alguns casos isolados.

Além disso, a falta de material didático adequado, o despreparo e desinteresse dos docentes em reląão ao tema têm 
marcado, em geral, a atuação da Universidade no ensino e pesquisa da Contabilidade Rural.

Como consequência, pode-se observar que engenheiros agrônomos e outros profissionais ligados à área têm ingressado no mercado de trabalho com uma visão parcial ou nenhuma nocão sobre o assunto.

b) atuacão precária das instituicões de pesquisa nesta área.

A maioria dos estabelecimentos de experimentacão e pesquisa agropecuários praticamente não possui, em seu quadro, profissionais trabalhando em Administracão Rural. Em 1976, apenas $0,7 \%$ dos pesquisadores de 46 estabelecimentos se dedicavam a esse assunto (DELGADO, 1979). E válido concluir que essa situação não tenha se alterado muito, até hoje, devido ao número reduzido de trabalhos publicados, especialmente sobre Contabilidade Rural.

c) carência de recursos humanos capacitados na transmissão de tecnologias administrativas ao meio rural.

E bem conhecido o grande número de frustrações que a Extensão Rural tem sofrido em seus esforcos para introducão da Contabilidade e outras técnicas administrativas, entre os produtores. Dentre as possiveis explicaços para este insucesso, têm sido apontadas na literatura, a falta de preparo dos extensionistas em Administracão Rural, decorrente tanto das falhas na formacão universitária, já mencionadas, como da falta de treinamento adequado. 
As tentativas de capacitação dos técnicos nessa área têm se dado mediante cursos intensivos de treinamento, com rápidas nocões teóricas evoluindo para observações empiricas (NETTO, 1979). Essa metodologia não permite uma idéia real do que seja a Contabilidade, nem de sua importância como fonte de informacões gerenciais para a empresa rural.

Consequentemente, o trabalho dos extensionistas junto aos produtores rurais é, de modo geral, incompleto limitando-se mais a aspectos puramente técnicos da producão, com poucas indicações de sua eficiência econômica e administrativa (ALBUQUERQUE, 1979).

d) falta de capacidade gerencial do produtor rural.

Como foi dito anteriormente, a maior parte das empresas rurais do Brasil vem sendo administrada de forma bastante tradicional. O empresário rural apresenta, normalmente, uma conduta improvisada em suas tomadas de decisões, desprovidos de qualquer conhecimento técnico do assunto. A Contabilidade Rural é, praticamente, desconhecida ou relegada a um plano secundário, como algo complexo com pouca utilidade prática.

As causas desse perfil apresentam-se como um complexo conjunto de fatores aliando falhas na politica agricola governamental, insucesso dos programas de treinamento e até variáveis de ordem social (ALBUQUERQUE, 1985).

e) ut111zacão de sistemas contábeis sem a capacidade analitica necessária. 
A partir da década de 50, iniciou-se um grande esforco das empresas de Extensão Rural (Coordenadoria de Assistência Técnica Integral-CATI; Associacão de Crédito e Assistência Técnica Rural do Paraná- ACARPA; Empresa de Assistência Técnica e Extensão Rural - EMATER), instituiç̃es de pesquisa (Instituto de Economia Agrícola - IEA) e da Universidade Federal de Vigosa (UFV), em levar a Contabilidade ao meio rural, sem contudo se alcancar os objetivos almejados (FRANCO, 1984). Dentre as causas deste insucesso, pode-se mencionar a inadequacão dos sistemas contábeis desenvolvidos para tal fim. Embora houvesse um certo detalhamento nos dados coletados, não se alcançava normalmente a fase de elaboração e análise das informaç̃es não havendo, portanto, o retorno esperado pelos produtores. Tal situacão persiste até hoje, com poucas excecões.

f) adoção de sistemas contábeis pressupondo a disponibilidade do empresário rural para o aprendizado e sua habilitação para o serviço contábil.

Um aspecto fundamental que deve ser reconhecido é que a implementąão dos sistemas das referidas instituicões pressupunha que o produtor aprendesse a realizar, por si mesmo, cada etapa do processo contábil. Isto é, a atuacão dessas entidades se dava no sentido de orientar o agricultor a "fazer" manualmente, sua própria Contabilidade, registrando fatos e transações, elaborando e analisando os relatórios e tomando decisões em tempo hábil.

Vale lembrar, que em outros setores mais modernos da economia brasileira (Indústria e Comércio), o empresário 
normalmente não se envolve com a escrituracão contábil de seus negocios. Mesmo os poucos que já adotam a Contabilidade Gerencial, relegam esse servico a profissionais especializados (Contadores, "Controllers", Firmas de Consultoria Contábil, etc.) que, inclusive, analisam os resultados obtidos, fornecendo parâmetros para as tomadas de decisões. E, note-se, que esses empresários detêm, geralmente, um nivel de instrução mais elevado que o dos produtores rurais.

Conclusão: não seria muito pretencioso esperar que o produtor rural desenvolvesse sua Contabilidade? Ou que o sistema de Extensão Rural realizasse o servico por ele?

g) adaptação de sistemas estrangeiros dissociados da realidade do setor rural brasileiro.

O desconhecimento das particularidades do setor rural brasileiro, aliado à falta de um bom embasamento técnicocientifico, tem levado à adaptacão de sistemas de Contabilidade Rural estrangeiros, tanto pelos meios universitários como pelos de pesquisa. Como era de se esperar, os resultados não têm sido satisfatórios, pois não são incorporadas muitas caracteristicas inerentes ao setor, como o problema inflacionário que torna altamente distorcidos os relatórios contábeis e indicadores. financeiros, restringindo sua capacidade informativa (FRANCO, 1984; NORONHA, 1987).

h) adaptação de sistemas importados de outros setores empresarials não-rurais. 
Uma outra tentativa ligada à Contabilidade Rural tem se dado em aєões isoladas nos centros de pesquisa e ensino de Administracão de Empresas e Ciências Contábeis, com a publicacão de livros e manuais (ALOE E VALLE, 1967; MARION, 1985a; MARION, 1985b; VALLE, 1983).

Este movimento, de forma geral, não tem influenciado a pesquisa, a extensão rural e o produtor agropecuário. Pelos mesmos motivos mencionados no item anterior, tem-se tentado a adaptacão de sistemas de Contabilidade Comercial e Industrial, pouco adequados para retratar as caracteristicas fundamentais da atividade agropecuária. Talvez essa seja a causa da grande preocupação que os autores demonstram em explicar detalhes técnicos das atividades produtivas, ao invés de centralizarem seus esforços na geração de uma tecnologia gerencial apropriada ao setor agropecuário (ALBUQUERQUE, 1985).

Além disso, não há evidências da geração de material mais didático ou elucidativo que desperte maiores interesses da clientela não-especializada.

A caracteristica mais relevante é que esses sistemas são voltados para finalidades fiscais, obedecendo aos dispositivos legais (legislação do Imposto de Renda, Lei das Sociedades Anônimas, etc.), o que praticamente invalida sua utilização para fins gerenciais.

i) não inclusão da Contabilidade Rural como instrumento de politicas governamentais, tanto agricolas como fiscais. 
Procurou-se modernizar as atividades agropecuárias, no passado, através da introducão de novas tecnologias via crédito rural. Embora houvesse disponibilidade de verbas para esse programa, ele foi falho na medida em que tornou obrigatório o uso de técnicas de producão modernas sem, contudo, dotar o empresário da capacidade gerencial necessária.

o problema está no fato de que tentou-se "utilizar um veículo (o crédito) para transferir algo que não havia sido definido (a administracão)" (ALBUQUERQUE, 1979 p.4).

Pela via fiscal, a difusão da Contabilidade Rural nunca foi devidamente incentivada, devido à quase inexistência de taxação da renda agrícola. Até 1990, a grande maioria dos produtores rurais era isenta de tributação e, portanto, não obrigada a se familiarizar com a escrituração contábil. Os poucos estabelecimentos que recolhiam o Imposto de Renda Rural eram taxados por uma aliquota irrisória de 6\%, com a possibilidade de deduzir, em até seis vezes o valor dos investimentos do periodo, da base de cálculo do imposto.

Segundo a antiga proposta do Ministério da Fazenda, que não chegou a vigorar em 1989 (Tabela 1), somente os produtores rurais com receita bruta anual acima de $100 \mathrm{mil}$ OTNs (Obrigações do Tesouro Nacional), pagariam Imposto de Renda e seriam assim, obrigados a apresentar um sistema contábil dentro das normas e principios contábeis introduzidos pela Lei no. 6404/76, das Sociedades Anônimas.

Entretanto, devido à distribuição da posse da terra no 
Tabela 1. Proposta de taxação da renda agricola, 1988

\begin{tabular}{|c|c|c|}
\hline ITEM & $\begin{array}{l}\text { PESSOA } \\
\text { FISICA }\end{array}$ & $\begin{array}{l}\text { PESSOA } \\
\text { JURIDICA }\end{array}$ \\
\hline $\begin{array}{l}\text { 1. Receita bruta anual até } 100 \mathrm{mil} \\
\text { OTNs }\end{array}$ & Isento & Isento \\
\hline $\begin{array}{l}\text { 2. Receita bruta anual acima de } 100 \\
\text { mil OTNs: } 3 \text { alternativas para } \\
\text { apuraça do IR: }\end{array}$ & & \\
\hline $\begin{array}{l}\text { a. Tributacão sobre o valor que } \\
\text { ultrapassar as } 100 \text { mil OTNs a }\end{array}$ & $\begin{array}{l}\text { Aliquota de } \\
10 \% \text { ou } 17 \%\end{array}$ & $\begin{array}{l}\text { Aliquota única } \\
\text { de } 17 \%\end{array}$ \\
\hline $\begin{array}{l}\text { b. Tributação s/ } 20 \% \text { da receita } \\
\text { bruta }\end{array}$ & $\begin{array}{l}\text { Aliquota de } \\
10 \% \text { ou } 17 \%\end{array}$ & $\begin{array}{l}\text { Aliquota única } \\
\text { de } 17 \%\end{array}$ \\
\hline $\begin{array}{l}\text { c. Apuração do lucro real } \\
\text { (receitas menos despesas) }\end{array}$ & $\begin{array}{l}\text { Aliquota de } \\
10 \% \text { ou } 17 \%\end{array}$ & $\begin{array}{l}\text { Aliquota única } \\
\text { de } 17 \%\end{array}$ \\
\hline
\end{tabular}

a/ De 720 - 2400 OTN, indice de 10\%; acima de 2400 OTN, indice de $17 \%$.

OBS: 0 saldo médio dos depósitos em Caderneta de Poupança Verde (fundo agrícola) seria abatido da renda tributável antes da aplicacão da alíquota para pessoas físicas e juridicas.

FONTE: ALVES, R. Proposta isenta rendimentos rurais de até 100 mil OTNs. Folha de São Paulo, São Paulo, 14 set. 1988. Caderno de Economia, P.B-9.

Brasil, o número de estabelecimentos com producão comercial é relativamente pequeno (HOFFMANN, 1982). Isso significa que, mesmo com a aplicação dessa proposta, apenas $10 \%$ dos 4,8 milhões de agricultores brasileiros (pessoas fisicas e empresas rurais) teriam seus rendimentos taxados pela Receita Federal.

Entretanto, há indícios de que essa situação deve mudar, a partir de 1991, em decorrência da nova legisląão do imposto de renda da atividade rural (Lei no.8023, de 12.04.90).

Além de eliminar todos os incentivos fiscais à agricultura, a nova Lei altera as fórmulas de cálculo do imposto, 
adotando a correção monetária (BTN) e introduzindo um aumento significativo nas alíquotas de tributacão da renda agricola (Tabela 2)(AITH, 1991; BONETTI, 1990; GARCIA, 1990).

A importância dessas medidas para a introducão da Contabilidade no meio rural reside no fato de que um maior número de agricultores deverá observar regras contábeis para viabilizar a declaração do Imposto de Renda. Isto é, a obrigatoriedade da escrituracão para as finalidades fiscais tornou-se mais abrangente, estendendo-se por um universo de pequenos e médios produtores que, até então, não realizava nenhuma forma de registro contábil (Tabela 3 ).

j) utilização de sistemas contábeis com processo de escrituração manual.

Um dos pontos-chave para a eficiência de um sistema contábil é justamente a rapidez na sua operacionalizacão. Os sistemas desenvolvidos por nossas empresas de Extensão Rural, instituições de pesquisa e universidades, têm recaído sobre o tradicional e moroso processo de escrituracão manual. Devido ao volume e complexidade naturais dos registros contábeis, a consequência é uma grande demora no retorno das informaçóes ao empresário, prejudicando as tomadas de decisões no momento adequado.

Em sintese pode-se concluir que, na verdade, a empresa rural brasileira não conta, ainda, com o apoio de um sistema contábil apropriado à atividade agropecuária e que produza informacões gerenciais relevantes, em tempo hábil. 
Tabela 2. Imposto de Renda da Atividade Rural, 1991

\begin{tabular}{|c|c|c|c|}
\hline PESSOA & $\begin{array}{c}\text { BASE DE CALCULO } \\
(\mathrm{BTN})\end{array}$ & $\begin{array}{c}\text { PARCELA A DEDUZIR } \\
\text { (BTN) }\end{array}$ & $\begin{array}{l}\text { ALIQUOTAS } \\
(\%)\end{array}$ \\
\hline \multirow{3}{*}{ FISICA } & \multicolumn{3}{|c|}{ Resultado da Atividade $a$} \\
\hline & - Até 22.800 & 6.840 & 10 \\
\hline & - Acima de 22.800 & 16.416 & 25 \\
\hline JURIDICA & Lucro da Exploração b/ & 0 & 25 \\
\hline
\end{tabular}

a/ Receita Bruta Recebida - Despesas Pagas + Ajustes

b/ Lucro Real

FONTE: IR agrícola terá BTN como base de cálculo. Folha de São Paulo, São Paulo, 07 jan. 1991. Caderno de Economia, p. B-4.

Tabela 3. Formas de Apuração do Resultado da Atividade Rural, 1991

\begin{tabular}{|c|c|c|c|}
\hline \multirow[t]{2}{*}{ PESSOA } & $\begin{array}{l}\text { RECEITA BRUTA } \\
\text { ANUAL-RBA (BTN) }\end{array}$ & FORMA & DESCRI CAO \\
\hline & $\mathrm{RBA}<70 \mathrm{mil}$ & SIMPLIFICADA & $\begin{array}{l}\text { - exige prova documental } \\
\text {-dispensa escrituracão al }\end{array}$ \\
\hline \multirow[t]{2}{*}{ FISICA } & $\begin{array}{l}70<\mathrm{RBA}<\begin{array}{l}700 \\
\text { mil }\end{array} \text { mil }\end{array}$ & ESCRITURAL & $\begin{array}{l}\text { - escrituracão rudimentar } \\
\text { por partidas simples }\end{array}$ \\
\hline & $\mathrm{RBA}>700 \mathrm{mil}$ & CONTABIL & $\begin{array}{l}\text { escrituracão contábil por } \\
\text { partidas dobradas em } \\
\text { livros registrados }\end{array}$ \\
\hline JURIDICA & qualquer RBA & CONTABIL & $\begin{array}{l}\text { escrituracão contábil } \\
\text { segundo "principios de } \\
\text { contabilidade geralmente } \\
\text { aceitos" (LEI DAS S.A.) }\end{array}$ \\
\hline
\end{tabular}

a/ Para fins de compensacão de prejuizos a pessoa física deverá manter escrituração de suas operacões, ainda que apure resultado pela forma simplificada.

FONTE: SAO PAULO. Instrução Normativa No. 138, de 28 de Dezembro de 1990. Diário Oficial da República Federativa do Brasil, Brasilia-DF, 31 de dez. 1990. Secão I, p.25782. Dispõe sobre a tributação dos resultados da atividade rural (Lei no. 8.023/90). 
Esse fato torna-se ainda mais restritivo, na medida em que fatores como a retirada de subsidios ao setor não mostram sinais de mudancas no futuro. Isto, aliado às altas taxas de inflação e aos riscos e incertezas inerentes às atividades agropecuárias, vem exigindo do produtor um maior preparo administrativo como condiç̃o "sine qua non" para a própria sobrevivência.

Deve-se levar em conta, também, que o grau de complexidade da empresa agropecuária é, hoje, muito maior principalmente nas regiões Sul e Sudeste onde a modernização das técnicas produtivas vem ocorrendo com maior intensidade.

A associação desses fatores tem provocado uma mudanca significativa na postura de muitos empresários rurais, que vêm sentindo a necessidade de tomar decisões baseadas não só em intuição, mas também em medidas e critérios quantitativos.

Essa conscientização tem favorecido um interesse crescente de profissionais pelo desenvolvimento de tecnologias gerenciais que permitam ao produtor uma administração mais eficiente. "O agricultor precisa receber um pacote técnicoeconômico integrado do qual necessariamente devem fazer parte importantes componentes de técnicas gerenciais e administrativas" (ALBUQUERQUE, 1979 p.56). Dentre elas, destaca-se o sistema de Contabilidade Rural como uma das primeiras áreas de conhecimento a compor o "Perfil Ideal do Administrador Rural" (ALBUQUERQUE, 1985 ).

Contribuindo para acentuar essa tendência, a partir do 
inicio da década de 80 , a micro-informática vem agindo no setor agropecuário, estimulando não só a incorporacão da Contabilidade Rural, mas também de outras técnicas administrativas (RODRIGUES DA CRUZ ${ }^{1 /}$, citado por FRANCO, 1984). Isso é possivel na medida em que o computador permite:

- armazenamento de grande volume de dados;

- processamento em grande velocidade;

- alto grau de confiabilidade;

- possibilidades de retencão e recuperacão de informações;

- grande flexibilidade;

- reducão dos custos, etc..

Acredita-se que o aparecimento de firmas de prestacão de servicos ("software houses"), assim como a eminente disseminaçao do uso de microcomputadores pelos escritórios da Extensão Rural estatal, contribuirão para facilitar o acesso de produtores a este instrumental, diminuindo sobremaneira o custo da automatização da Contabilidade para as empresas rurais.

Essa conjuntura certamente estimulará uma maior demanda por profissionais qualificados em Administração Rural. Dessa maneira, o desenvolvimento de material especifico nessa área seria de grande utilidade para engenheiros agrônomos e outros profissionais que trabalham diretamente com empresas rurais.

Nesse contexto encontram-se, portanto, subsidios e 1) RODRIGUES DA CRUZ, E., 1983. Informática a servico do produtor rural. Trabalho apresentado no 40. Congresso Paulista de Agronomia, realizado em Campinas - SP. 
justificativas para que o desenvolvimento de um modelo de Contabilidade Rural para microcomputador seja considerado de grande importancia. Esse é o objetivo do Projeto "Uso do Microcomputador na Contabilidade Rural", do qual esta dissertação faz parte.

\subsection{Objetivos}

\subsubsection{Objetivo Geral}

Desenvolver um Modelo de Contabilidade Rural que adotando padrões conceituais e metodológicos já consagrados, venha de encontro às necessidades gerenciais da empresa rural brasileira, servindo também como instrumento para uso de instituiç̃es prestadoras de serviço públicas e privadas.

\subsubsection{Objetivos Especificos}

a) Desenvolver um Modelo de Contabilidade Rural para as finalidades gerenciais da empresa agropecuária.

b) Esclarecer e adotar princípios contábeis e padrões metodológicos que confiram ao sistema maior capacidade informativa, confiabilidade e eficiência nos resultados.

c) Desenvolver procedimentos que permitam tornar o sistema mais didático e acessivel à clientela não-especializada.

E importante lembrar que procurar-se-á conferir ao Modelo o enfoque gerencial esperado sem, contudo, colocar em risco o caráter contábil do sistema. 


\section{REVISAO DE LITERATURA E METODOLOGIA}

Como foi mencionado anteriormente, este trabalho faz parte de um projeto, cujo objetivo principal é desenvolver um Modelo de Contabilidade Rural para microcomputador e que será executado em duas etapas. A primeira, objeto desta pesquisa, tem como meta a elaboração do Modelo propriamente dito, a partir do estudo dos sistemas existentes na literatura. A segunda etapa visa o desenvolvimento do "software" para o modelo proposto.

Neste capitulo pretende-se fazer a revisão dos principais modelos de Contabilidade Rural existentes no Brasil e no exterior, na medida em que são descritos seus componentes básicos. Assim, na primeira parte, são discutidas as informaç̃es mais comumente geradas a partir dos dados coletados pelos diferentes sistemas.

Em seguida, são discutidos os elementos básicos utilizados em cada um deles: processos de escrituração, periodo e regime contábeis, formas de lançamento, livros para registros e plano de contas. Finalmente, discute-se o efeito da inflação no sistema de Contabilidade e os princípios e convencões contábeis geralmente aceitos.

\subsection{Informąres Geradas pelo Sistema Contábil}

No processo de estruturacão de um modelo de Contabilidade para fins de análise dos negócios da empresa rural, é necessário inicialmente definir quais as informacões mais relevantes que se pretende gerar. 
Como providência inicial para se colocar em funcionamento a "máquina contábil da empresa" impõe-se a planificacão geral de seu setor contábil, partindo do estudo da natureza da entidade, no caso a empresa rural e abrangendo: 0 conhecimento de sua estrutura orgânica, o fluxo das informaçóes dentro dessa estrutura, as caracteristicas do processo de tomada de decisão, etc.. Juntamente com o conhecimento dos objetivos gerais da empresa será possivel, então, determinar o conjunto de informacões que o empresário necessita ter em mãos e a forma na qual ele the deve ser apresentado.

Embora existam particularidades quanto às informacões que cada empresa deseja gerar, algumas podem ser consideradas de caráter mais geral. Assim, na literatura brasileira, existem dois tipos já consagrados de relatórios e seus respectivos indicadores financeiros e econômicos. São eles:

1 - Balanco Patrimonial ou Demonstracão do Patrimônio Iiquido e

2 - Demonstracão do Resultado do Exercicio ou Demonstracão de Lucros e Perdas.

Outro demonstrativo bastante utilizado pelas empresas rurais norte-americanas, mas praticamente ausente na literatura brasileira de Contabilidade Financeira é:

3 - Demonstracão do Fluxo de Caixa ou Demonstracão de Fontes e Usos de Recursos.

Além desses Demonstrativos Financeiros, são geralmente 
do interesse da empresa:

4 - Demonstracão do Resultado por Atividade de Producão Individual e

5 - Informativos Auxiliares (Controles e Relatórios Extracontábeis).

Por intermédio desses relatórios contábeis é possivel fornecer ao empresário um fluxo continuo de informações que permitem a análise da empresa sob diversos ângulos. A seguir descreve-se cada um deles.

2.1.1. Balanco Patrimonial (BP) ou Demonstracão do Patrimônio
Liquido

O BP é um tipo de demonstrativo financeiro que oferece uma visão estática da estrutura de capital da entidade em uma determinada data, refletindo os efeitos dos atos e fatos administrativos sobre os elementos patrimoniais.

Ou seja, o BP tem como finalidade mostrar a situação patrimonial e financeira da empresa, em determinado ponto no tempo possibilitando a identificação das alterações ocorridas entre dois ou mais pontos.

A análise desse demonstrativo é fundamental para que o empresário avalie as consequências de sua gestão sobre os recursos que está administrando e sobre as participacões 2) Esse item está baseado, principalmente, na seguinte literatura: ANGELICO (1982); IUDICIBUS et alii (1983); FRUGOLI (1977); MARION (1986); SCOTT JR. (1977). 
(proprietários) e reinvindicações (credores) contra esses recursos. Serve, então, como um "painel geral de controle" para que a administracão possa conhecer a atual situacão e assim tracar novos rumos para a empresa.

A razão entre os vários itens do Balanco permite o cálculo de diversos indicadores financeiros úteis na determinaça da situacão de liquidez e solvência da empresa e na avaliacão do grau de risco associado aos empréstimos e investimentos.

Finalmente, o Balanço Patrimonial é a demonstração que encerra a sequência dos procedimentos contábeis, sintetizando todas as anotações realizadas nos livros contábeis essenciais e auxiliares na forma dos três componentes gerais do patrimônio: Ativo, Obrigações e Patrimônio Líquido. O termo "Balanço" reflete justamente o equilibrio entre esses elementos pela identidade:

ou

$$
\text { Ativo = Passivo }
$$

Ativo = Obrigações + Patrimônio Liquido

Como foi dito, o Balanco Patrimonial tem um conceito estático no tempo, indicando a natureza e o valor do Ativo, Obrigações e Patrimônio Liquido na data de seu levantamento. Embora essa análise forneca, normalmente, uma boa idéia da situacão geral é preciso esclarecer que não é muito reveladora pois, entre um Balanço e outro, ocorrem alterações na situacão patrimonial - financeira da empresa. Na verdade, o percentual de aumento do Patrimônio Líquido entre dois Balancos mede a taxa de crescimento da empresa rural. 
Portanto, há necessidade da análise de dois ou mais Balancos consecutivos para que se possa identificar as mutacões e conhecer a tendência financeira dos negócios da empresa ao longo do periodo.

A partir de uma série histórica de Balancos é possivel estabelecer comparacões entre o desempenho da empresa e de outras do mesmo ramo e ainda confrontar o que foi obtido com as metas tracadas, aperfeicoando os futuros planejamentos.

No Brasil, o Ministério da Fazenda através da Lei das Sociedades Anônimas (No. 6404/76) baixou principios e normas de Contabilidade às Sociedades Anônimas de Capital Aberto, inclusive no que tange à forma e ao controle dos demonstrativos financeiros. Pelo Decreto-lei No. $1598 / 77$ isso foi estendido às demais pessoas juridicas que se submetem à tributacão do Imposto sobre a Renda com base no Lucro Real e são obrigadas a elaborar demonstrativos financeiros (IUDICIBUS et alii, 1983).

Embora seja crescente o número de empresas urbanas que já possuem dois tipos de sistemas contábeis (para fins fiscais e para fins gerenciais) ${ }^{3 /}$, acredita-se que a maioria das empresas brasileiras que elabora o Balanço Patrimonial segue as determinações da Lei. Também se enquadram neste grupo as empresas rurais que, pelo seu grande volume de negócios, são obrigadas a apresentar anualmente o seu BP.

Assim, este demonstrativo é utilizado muito mais como um instrumental de administrąão do Imposto de Renda, do que como 3/ Vide MARTINS, 1987 P.21. 
uma fonte de informacões gerenciais para a empresa. Os próprios dispositivos legais (Principio do Custo Histórico como Base de Valor, Convencão do Conservadorismo, etc.) impedem que as informacões do Balanco sirvam igualmente aos dois propósitos.

A classificação dos elementos patrimoniais padronizada pela Lei também mostra-se pouco adequada à empresa rural. No Ativo Imobilizado, por exemplo, são incluidos, sem separacão, todos os bens que se destinam à manutencão das atividades da empresa (ANGELICO, 1982; IUDICIBUS et alii, 1983; MARION, 1986). Entretanto, a terra para a empresa rural tem uma conotacão bastante diferente das firmas comerciais e industriais. Ela representa o item do Ativo de maior valor e sua venda acarreta, via de regra, o encerramento das atividades desta empresa. Portanto, não seria recomendável classificar a terra da fazenda no mesmo nível de facilidade de venda de veiculos, maquinaria, equipamentos, implementos, etc., que são vendidos facilmente em um prazo médio.

A maioria das nossas instituições de pesquisa, universidades e empresas de Extensão Rural sequer propõe a elaboracão deste demonstrativo, o que denota um aparente desconhecimento sobre sua importância como fonte de informacões para o processo de gerência. As poucas que o fazem, elaboram balanços incompletos, sem grupos de contas e não consideram o Patrimônio Liquido como um componente do Passivo, além de adotarem uma terminologia confusa (CATI, 1980; TEIXEIRA et alii, 1981). 
A Empresa de Assistência Técnica e Extensão Fural do Estado do Rio Grande do Sul (EMATER, 1987) é a única que elabora este demonstrativo utilizando critérios mais adequados à análise gerencial. Entretanto, a elaborąão do Balanço Patrimonial acaba tendo como finalidade principal o fornecimento de dados para demonstrativos de resultados individuais das atividades de produ६ão da empresa rural.

Observa-se também, no geral, a ausência do uso de indicadores financeiros e econômicos. Esse fato pode ser causado tanto pelo desconhecimento do assunto, como pela total inexistência de indicadores-padrão que forneçam uma base de comparação confiável. Nos Estados Unidos, por exemplo, existem publicaç̃es que fornecem indices médios para grupos de empresas da mesma atividade ou porte semelhante, permitindo a autoavaliạ̃ão ou comparação do desempenho com outras empresas do mesmo ramo (LEE et alii, 1980).

Portanto, a proposição de um modelo de Balanço Patrimonial pode tomar como base a estrutura geral padronizada pela Lei, com algumas alteracões no sentido de se tornarem as informacões mais apropriadas às necessidades analiticas da empresa rural. 
2.1.2. Demonstração do Resultado do Exercicio (DRE) ou Demonstracão de Lucros e Perdas

Como foi exposto anteriormente, no periodo de tempo situado entre o levantamento de dois Balancos Patrimoniais consecutivos, ocorrem atos e fatos administrativos que alteram a composição do patrimônio da empresa. Tais eventos referem-se à transacões envolvendo fontes e usos de recursos que causam variacões no Patrimônio Liquido.

A Demonstração do Resultado do Exercicio tem como finalidade revelar o desempenho econômico da empresa (lucro ou prejuizo), justificando as decisões administrativas tomadas e esclarecendo a maioria das causas das alteraçós sofridas pelos componentes patrimoniais, durante o periodo ou exercicio contábil considerado.

Assim sendo, é um tipo de demonstrativo financeiro com um conceito dinâmico no tempo, o que complementa a análise estática oferecida pelos Balanços Patrimoniais.

Mais especificamente, a DRE tem como funcão designar as causas das variacões patrimoniais a periodos de tempo determinados, permitindo que haja uma confrontacão real entre fontes e usos de recursos, para uma determinacão precisa do resultado obtido.

4) Este item está baseado principalmente em ANGELICO (1982); BOEHLJE \& EIDMAN (1984); FREY \& KLINEFELTER (1978); FROGOLI (1977); IUDICIBUS et alii (1983); JAMES \& STONEBERG ( 1986 ); LEE et al11 (1980); MARION (1985b); MARION (1986); MARTINS (1987). 
Portanto, é um demonstrativo essencial para que a gerência possa dimensionar e controlar as causas das alteracões que visualizou no BP.

Por outro lado, a DRE é um resumo das receitas e ganhos, despesas e perdas, cuja diferenca fornece o resultado econômico que altera o Patrimônio Liquido da empresa durante o período considerado. Seus resultados possibilitam a apuracão de medidas de retorno aos fatores de producão que não recebem pagamento direto na empresa: capital empatado, mão-de-obra familiar e administracão. Tais medidas servem como indicativos da eficiência no uso desses recursos, direcionando os negócios.

Com base nos dados fornecidos pelos Balangos Patrimoniais e pela Demonstracão do Resultado do Exercício, podem ser calculados vários tipos de indicadores econômicos, como por exemplo aqueles que relacionam o retorno liquido do período com outros elementos dos Demonstrativos Financeiros. São quocientes de retorno ao capital que permitem a avaliacão do potencial de crescimento da empresa no periodo e comparacões com outras empresas do ramo. Todas essas informacões são igualmente úteis às decisões de credores e investidores em geral.

Segundo a Lei No. 6404/76, a DRE obedece um modelo de uso obrigatório denominado Demonstracão do Resultado do Exercicio (ANGELICO, 1982; IUDICIBUS et alii, 1983; MARION, 1986). Notam-se diferencas bem acentuadas entre o modelo de DRE da Lei e os demonstrativos adotados pelas instituicões públicas estudadas que se basearam nos sistemas norte-americanos de Contabilidade Rural. 
Estes últimos, podem ser representados pelos modelos de BOEHLJE \& EIDMAN (1984), FREY \& KLINEFELTER (1978), JAMES \& STONEBERG (1986), LEE et alii (1980).

O modelo de DRE da Lei pode ser dividido em dois grandes grupos: Receitas e Despesas Operacionais e Receitas e Despesas Não-Operacionais. O termo operacional refere-se às atividades as quais a empresa se dedica, o que corresponde ao seu objeto social. Assim, a Receita Operacional é composta das vendas dos bens e servicos produzidos que se relacionam diretamente com os negócios da empresa.

O grande grupo denominado "Despesas Operacionais" é, na realidade, formado por dois componentes: Custo do Produto ou Servico Vendido e Despesas Operacionais propriamente ditas. 0 primeiro corresponde ao valor dos recursos, variáveis e fixos, utilizados na producão da parcela vendida. Despesas Operacionais propriamente ditas, por sua vez, representam gastos necessários para vender os produtos e servisos, administrar a empresa e financiar suas operações.

Todas as receitas e despesas referentes ao periodo contábil e que não se relacionam com o objeto social da empresa, isto é, com suas atividades produtivas, são classificadas como Receitas e Despesas Não-Operacionais.

A denominação da DRE utilizada pelas instituições públicas estudadas é bem variável: "Apuração dos Resultados" (CATI,1980; TEIXEIRA et al11, 1981), "Resultado EconômicoFinanceiro da Fazenda" (BEMELMANS, 1978), "Demonstrativo de 
Resultados" (EMATER, 1978).

Já nos modelos norte-americanos, a terminologia consagrada, para esse demonstrativo, é "Demonstrą̧ão de Renda Liquida", cujas receitas e despesas são classificadas como agrícolas e não-agricolas (farm e off-farm), o que corresponde, aproximadamente, à divisão operacional e não-operacional usada pela Lei das S.A.. Nos modelos brasileiros, a classificação desses itens varia muito conforme a instituicão.

o mesmo ocorre com a terminologia adotada: Receitas e Despesas (CATI, 1980; BEMELMANS, 1978), Recebimentos e Despesas (TEIXEIRA et alii, 1981), Rendimento Bruto, Custos Variáveis e Fixos (EMATER, 1978), Produto Bruto, Encargos Variáveis e Encargos Fixos (ACARESC, 1986).

Todos esses modelos, entretanto, reconhecem o consumo interno, os pagamentos em espécie, o uso interno da producão agropecuária e a alteracão no valor dos estoques, como componentes da Renda da empresa. A importancia de cada um desses itens é, sem dúvida, variável. Espera-se, no entanto, que a porcentagem da produça agropecuária consumida pela família seja maior nas pequenas propriedades, enquanto que o seu uso interno na geração de outros bens seja um componente importante da Renda, independentemente do tamanho da empresa.

Fica evidente, portanto, que nos modelos das instituicões públicas estudadas, confronta-se o Valor Bruto da Prodųão Anual da empresa com o custo necessário para gerá-lo. 
Isso não ocorre no modelo da Lei onde a receita é reconhecida apenas no instante em que ocorre o seu fato gerador, isto é, no momento da transferência do bem ou servico a terceiros, independentemente de ter havido ou não o recebimento (Princípio da Realização da Receita). Em seguida, essa receita é atribuida ao periodo contábil a que pertence (Principio da Competência) e então confrontada com as despesas incorridas na sua geracão (Princípio da Confrontacão da Despesa).

Portanto, nesse caso, a receita é realizada somente no moménto da venda e consequentemente as despesas, a ela associadas, correspondem ao "Custo do Produto Vendido". Ou seja, enquanto não houver venda, os custos de producão permanecem "ativados" no estoque do produto em formaç̃o ou acabado (MARION, 1986).

Assim sendo, os dispositivos legais não permitem a apropriação da receita antes da transferência do produto e, dessa forma, não é reconhecida a renda não-caixa gerada pela producão, nem tampouco o ganho econômico (ou perda) devido às alteracões de precos dos estoques (lucro ou prejuizo não-realizado financeiramente).

Além disso, com a avaliação dos estoques pelo custo original de producão ou aquisicão (Principio do Custo Histórico como Base de Valor) acaba havendo o confronto da "Receita Bruta", em moeda atual, com o "Custo do Produto Vendido" que acumula valores de poder aquisitivo diferentes. Consequentemente, a DRE vê reduzida a sua capacidade de fornecer informaçóes úteis ao 
processo de gerência.

Nota-se também que, na DRE desse modelo, não há um tratamento uniforme para as variações do Patrimônio Liquido sem a realizacão financeira de receitas e despesas. Ou seja, o critério para a classificação de ganhos (superveniências ativas e insubsistências passivas) e perdas (insubsistências ativas e superveniências passivas) é bastante variável.

Em alguns modelos, as referidas variaçoes são consideradas como "Receitas" e "Despesas" Não-Operacionais (ANGELICO, 1982; VALLE, 1983). Outros autores preferem inclui-los como parte da Receita Operacional Bruta (MARION, 1985a e 1985b; FROGOLI , 1979).

Embora a estrutura dos modelos norte-americanos seja mais ou menos uniforme não há, como nos Demonstrativos da Lei, um padrão estabelecido quanto à terminologia para designar seus componentes, nem mesmo para definição de cada um deles. Este fato se torna ainda mais grave nos modelos brasileiros.

As falhas mais evidentes, entretanto, referem-se a determinados conceitos utilizados nos modelos de instituições públicas brasileiras. E o caso, por exemplo, de se contabilizar as compras e vendas de bens de capital como despesas e receitas, juntamente com as depreciacões dos mesmos (BEMELMANS, 1978 p.8).

Além disso há, em alguns casos, falta de clareza quanto aos ajustes necessários para se calcular o valor dos insumos usados na producão anual da empresa. Nos modelos da CATI (CATI, 
1980) e da EMATER/RS (EMATER, 1987), por exemplo, as desfesas em dinheiro são registradas como custos o que, certamente, não é correto já que a quantidade de insumo usada na produção não corresponde, necessariamente, ao que foi comprado durante o ano.

As medidas de resultado bruto ou líquido seguem cálculos, os mais variados (Renda Bruta Total, Renda Liquida em Dinheiro, Renda Liquida Total, Renda Total do Estabelecimento, etc.). Além disso, esses modelos imputam taxas bastante arbitrárias aos fatores não remunerados, como por exemplo: 9\% para antmais de trabalho e producão e $12 \%$ para estoques (CATI, 1980 P. 35).

Fica claro, portanto, que ao contrário do Balanço Patrimonial, o modelo da Demonstração do Resultado do Exercicio da Lei precisa ser cuidadosamente reformulado para melhor atender às necessidades gerenciais da empresa rural. Ao mesmo tempo, dentro dos objetivos deste trabalho, é desejável que o modelo a ser proposto esteja o mais próximo possivel da estrutura já consagrada na literatura contábil brasileira.

2.1.3. Demonstração do Resultado por Atividade de Producão
Individual

Como foi discutido, um dos objetivos da Contabilidade é proporcionar as informações necessárias a uma correta avaliação das alternativas de produção da empresa.

5/ Esse item está baseado, principalmente, na seguinte literatura: ARMBRUSTER (1983); BRANNEN (1977); IUBICIBUS et alii (1983); JAMES \& STONEBERG (1980) e (1986); LEITE (1988); MARTINS (1987). 
diversifica@ão da producão, um meio para reduzir seus riscos e à medida que a empresa evolui, mais complexas se tornam as decisões relativas a cada produto, seja ele agricola ou animal.

Uma série de questões, envolvendo cada atividade individualmente, poderá surgir e suas soluções dependem, basicamente, das informações fornecidas pela Contabilidade (IUDICIBUS et alii, 1983). Dentre elas podem-se destacar as mais importantes para o setor rural:

- Quanto contribui cada produto para o Lucro Bruto da Produção da empresa?

- Quais os Custos Variáveis envolvidos na obtenção de um dado produto?

- Qual o volume minimo de produção necessário para se cobrir o Custo Variável Total da atividade?

- Quais os custos mais relevantes e que devem ser rigorosamente controlados?

A "Contabilidade por Atividade", tambem denominada Contabilidade de Custos, tem como objetivo responder à essas questões através da compilação, determinação e análise dos dados necessários à decisões seguras e fundamentadas, tendo como alvo a rentabilidade de cada atividade e os fatores que a afetam. Se a empresa dispuser de uma série histórica desses registros e relatórios, poderá avaliar o seu desempenho em manter ou melhorar suas medidas de lucratividade ou eficiência produtiva, bem como 
compará-las com outras empresas do mesmo ramo.

Este tipo de análise, por atividade de produção da empresa, é bastante recente na Contabilidade. Seu desenvolvimento teve inicio com o crescimento das empresas, especialmente as indústrias, com a finalidade de avaliar estoques e não de servir como instrumento auxiliar de tomada de decisão. Entretanto, este ramo da Contabilidade passou, nos últimos tempos, a desempenhar um importante papel que consiste na geração de informações mais relevantes para o controle da produtividade e para orientacão dos administradores no sentido de se obter uma maior reducão dos custos e consequente ampliação da rentabilidade da empresa (LEITE, 1988; MARTINS, 1987).

Basicamente, a Contabilidade de Custos é uma metodologia que permite atribuir os custos aos devidos produtos ou fases produtivas. A mecânica contábil é idêntica à utilizada na apuracão do "Custo do Produto Vendido" na DRE da Lei. A Demonstracão do Resultado por Atividade de Producão é, em geral, composta de duas partes : uma que se refere à Receita do Produto Vendido ou Servico Prestado e outra que diz respeito aos Custos de Producão, desse produto ou servico, subdivididos em variáveis e fixos. A diferença é denominada Lucro Bruto da Producão da Atividade.

Verifica-se que, na literatura contábil brasileira, a Contabilidade de Custos se desenvolve separadamente da Contabilidade Financeira, porque enquanto esta visa a geracão de relatórios para usuários externos, a primeira tem como finalidade 
principal o uso interno gerencial, dentro do planejanento e controle (LEITE, 1988).

Já na literatura norte-americana observa-se que esses dois ramos se desenvolvem conjuntamente, com um enfoque gerencial. Em outras palavras, a "Análise Econômico-Financeira por Atividade de Producão" deriva dos registros contábeis da empresa como um todo, atraves de um sistema de "Centros de Responsabilidade", que aloca as receitas e despesas do periodo entre as diferentes atividades produtivas. Dessa forma, é possivel optar entre ter informacões sobre a rentabilidade total da empresa ou de cada atividade individualmente ou ambas, o que torna a análise mais completa e eficiente (ARMBRUSTER, 1983; JAMES \& STONEBERG, 1980 e 1986).

Assim, a "Contabilidade por Atividade" (Enterprise Accounting) tem como ponto de partida os mesmos dados básicos coletados para a empresa total. As informações relativas a cada atividade compreendem :

1) Demonstracão de Rentabilidade da Atividade (Producão Agricola ou Producão Animal) - DRA - com a mesma estrutura geral da DRE da empresa.

2) Medides de Producăo, Eficiencia Produtiva e Lucratividade obtidas a partir de registros e controles extracontábeis e da DRA de cada atividade.

E importante ressaltar que essa análise se concentra nas atividades de produção mais relevantes para a empresa. Em 
suma, é um sistema de controle que proporciona "sinais de alerta" se ocorrem desvios, orientando as tomadas de decisões.

Os dados mais significativos para essa análise referem-se aos custos variáveis, que se constituem na "chave" para o planejamento da produção.

Isso se deve ao fato da empresa rural defrontar-se com um mercado de estrutura competitiva na venda de seus produtos, sendo portanto "tomadora de precos". Por isso, a curto-prazo, os custos variáveis são os que importam na decisão de cultivar ou criar. Os custos fixos, por sua vez, só interessam quando a classe produtora exerce uma certa influência sobre o preco do produto, como ocorre com a cana-de-açúcar.

Embora para a maioria dos casos somente os custos variáveis sejam relevantes, é importante que os relatórios das atividades de produção individuais incluam as duas categorias de custo, de forma a tornar flexível o seu uso.

A maioria dos sistemas de Contabilidade das instituições públicas estudadas desenvolvem algum tipo de análise por atividade de produção. Normalmente, tenta-se levantar as receitas e os custos por exploracão, chegando à estimativas da Renda Bruta ou Liquida.

Em alguns casos (ACARESC, 1986; BEMELMANS, 1978 E 1979; EMATER, 1987), a análise é complementada com medidas de eficiência produtiva calculadas a partir de dados coletados extracontabilmente. 
Alguns desses sistemas (CATI, 1980; TEIXEIRA et alii, 1981), embora coletem dados de receita e custo por atividade, não chegam a calcular medidas de retorno bruto ou liquido dentro de padrões que permitam uma avaliação correta da lucratividade de cada atividade e dos fatores que a afetam.

Finalmente, pode-se concluir que o modelo da Demonstração do Resultado por Atividade de Producão (Contabilidade de Custos) mostra-se inadequado já que incorre nas mesmas falhas apontadas na Demonstracão do Resultado do Exercicio. Assim, para atender melhor às necessidades analiticas da empresa rural, é recomendável que o modelo proposto incorpore as alteracões sugeridas pela "Contabilidade por Atividade" norteamericana.

2.1.4. Demonstração do Fluxo de Caixa (FC) ou Demonstração das Fontes e Usos de Recursos

A Demonstracão do Fluxo de Caixa tem como finalidade mostrar as entradas e saidas de dinheiro que movimentam as atividades da empresa ao longo dos periodos, normalmente mês a mês, tornando possivel identificar as épocas mais criticas da empresa quanto à disponibilidade de capital, ou épocas de maior superávit de caixa, o que permite um melhor planejamento do uso dos recursos.

A Demonstracão do Fluxo de Caixa também é usada como um

6) Esse item está baseado, principalmente, na seguinte literatura: JAMES \& STONEBERG (1980); LEE et alii (1980); MARION (1986); MATTOS et alii (1988); NORONHA (1987). 
"veiculo de comunicaçao" entre o empresário rural e seus financiadores, facilitando a obtencão de empréstimos e mantendo uma linha de crédito segura.

Esse instrumento torna-se particularmente útil às empresas rurais, devido à estacionalidade de suas receitas e despesas, o que é acentuado ainda mais pelas altas taxas de inflação e dificuldades na obtenção de crédito.

A estrutura geral do Fluxo de Caixa parte da identidade:

TOTAL DE FONTES $=$ TOTAL DE USOS
DE RECURSOS

onde as Fontes de Recursos são representadas pelas Disponibilidades iniciais do periodo, as entradas de dinheiro e novas dividas contraidas pela empresa, ao longo desse periodo.

Já os Usos de Recursos referem-se às saidas de dinheiro (incluindo retiradas do proprietário), pagamento de dividas e as Disponibilidades finais da empresa no periodo.

Portanto, o Fluxo de Caixa nada mais é do que o registro dos movimentos das contas Caixa e Bancos (Disponibilidades), agrupados de maneira a facilitar a análise dos mesmos.

A Demonstração do Fluxo de Caixa não é mencionada entre os demonstrativos financeiros de uso obrigatório pela Lei No. 6404/76 (IUDICIBUS et alii, 1983). 
Entre os modelos das instituições públicas estudadas, não há propostas de elaboracão de Fluxos de Caixa, o que torna a análise da empresa incompleta, visto que o $B P$ e a DRE são instrumentos importantes de análise patrimonial-financeira, mas inapropriados para detectar problemas de disponibilidade de dinheiro ao longo do ano e apontar suas causas.

Assim sendo, neste trabalho procurar-se-á adaptar, às necessidades gerenciais da empresa rural, o demonstrativo de Fluxo de Caixa comumente adotado pela literatura contábil brasileira.

2.1.5. Informativos Auxiliares

Embora os demonstrativos financeiros da empresa fornecam, normalmente, uma boa idéia de sua situacão geral, é preciso esclarecer que podem existir vários aspectos não evidenciados por esta análise.

Um perfeito diagnóstico econômico e financeiro da empresa deverá incluir outras análises além daquelas proporcionadas pelos demonstrativos já discutidos.

Essas informações adicionais podem ser obtidas fora do sistema contábil propriamente dito, na forma de Controles ou Relatórios Extracontábeis que fornecem ao empresário rural maiores detalhes sobre seus bens, direitos e obrigacões, bem como dados para a elaborąão dos demonstrativos financeiros.

7. Este item está baseado principalmente na seguinte literatura: ANGELICO (1982); JAMES \& STONEBERG (1980) e (1986); VALLE (1983). 
Os informativos auxiliares mais importantes são:

Controle de Estoques- diz respeito ao sistema de inventário utilizado para controlar os bens em estoque (produtos em elaboração, produtos acabados, insumos e materiais de consumo). Fornece dados sobre a composição física e valor dos estoques, discrimina o regime de controle adotado (Periódico ou Permanente) e estabelece o critério para avaliação dos bens (Custo Especifico, PEPS-"O Primeiro que Entra é o Primeiro que Sai", UEPS-"O Oltimo que Entra é o Primeiro que Sai", Custo Médio, Valor de Mercado, "Custo ou Mercado,, o Menor", etc.)(MARION, 1986; MARTINS, 1987).

Controle de Ativo Permanente Imobilizado- refere-se ao controle dos bens de capital, destinados à manutenção das atividades da empresa. Discrimina para cada item, a data e o valor de aquisição e venda, a vida útil estimada, o percentual de uso por atividade de produção, a depreciação mensal ou de qualquer fração do periodo contábil, a depreciação acumulada, o ganho ou perda real na venda, etc..

Controle de Contas a Pagar - diz respeito ao controle dos créditos comerciais ou pessoais (compras à prazo) ou empréstimos de terceiros. Discrimina, para cada credor descrito, - valor da divida inicial, as amortizaçóes já realizadas, o saldo a pagar e os valores dos pagamentos a serem efetuados periodicamente.

Controle de Contas a Receber - refere-se ao controle dos créditos concedidos à terceiros (vendas à prazo) ou 
empréstimos. Discrimina, para cada devedor descrito, o valor de sua divida inicial, as amortizacões já recebidas, o saldo a receber e os valores dos pagamentos a serem recebidos periodicamente.

Controle de Financiamentos Bancários - refere-se ao controle de financiamentos para custeio ou investimento obtidos. Discrimina, para cada Banco descrito, o valor inicial do financiamento, as amortizaçoes já realizadas, o saldo a pagar e os valores dos pagamentos a serem efetuados periodicamente.

Controle de Pagamento de Empregados - refere-se ao controle de mão-de-obra permanente e avulsa (temporária). Discrimina, para cada empregado descrito, sua remumeração, isto é, ordenado, horas extras, gratificações, abonos, etc. e os descontos com previdência social, imposto de renda na fonte, faltas, adiantamentos, contribuicão sindical, etc. fornecendo, finalmente, a importância liquida a ser paga a cada empregado.

Todos os modelos das instituicões públicas estudadas incluem formas rudimentares de controle ou relatório extracontábil, como: Controle de Contas a Pagar (CATI, 1980); Controle de Contas a Pagar e Contas a Receber (TEIXEIRA et alii, 1981); Controle de Conta Corrente e Registros da Producăo (BEMELMANS, 1978); Medidas de Eficiência Produtiva (EMATER, 1978; ACARESC, 1986).

Além do que foi exposto, outros informativos mais ligados a cada atividade individualmente, podem ser elaborados possibilitando o seu controle técnico, através da apuracão de 
rendimentos operacionais e de medidas de eficiencia das exploracões animais, culturas, mão-de-obra, veiculos, maguinaria e capital.

Nesse contexto, pode-se citar:

Culturas: os chamados registros de producão ("production records") como: qualidade das sementes ou mudas, variedades, espacamentos, adubacões realizadas, área plantada, área colhida, produçóes obtidas, produtividades, etc..

Criações: controles da producão de animais e produtos animais, controles do crescimento animal, controles da reproducão, controles sanitários, controles de mortes e nascimentos, conversão alimentar, etc..

A partir desses dados podem ser calculadas inúmeras medidas de eficiência produtiva, que juntamente com os custos de producão fornecidos pelas Demonstrações de Resultados, særvem de suporte a uma análise mais detalhada das atividades da empresa (JAMES \& STONEBERG, 1980 e 1986).

Entretanto, tais informacões não serão fornecidas pelo sistema contábil proposto neste trabalho. Embora de grande importância, a geração das mesmas requer um estudo especial, que foge ao escopo desta pesquisa. 


\subsection{Elementos Básicos de um Sistema Contábil}

Definidas as informacões mais relevantes a serem geradas pelo sistema contábil é necessário, então, caracterizar os elementos básicos que irão reger o seu funcionamento. Assim sendo, este item pretende revisar, criticamente, as opcões adotadas pelos modelos de Contabilidade das instituicões públicas brasileiras e por aqueles que seguem os dispositivos da Lei.

Tais elementos referem-se, basicamente, às formas de interpretacão e classificacão dos atos e fatos administrativos, resultando em um processo de acumulação de registros e dados que posteriormente farão parte dos relatórios contábeis, os quais, finalmente, serão interpretados proporcionando informações que auxiliem as tomadas de decisões.

Basicamente, podem-se destacar os seguintes elementos:

- o processo de escrituracão contábil;

- o período contábil;

- o regime contábil;

- a forma de lanqamento dos fatos e transacões contábeis;

- olano de contas;

- os livros contábeis;

- o tratamento da inflacão pelo sistema contábil;

- Od prinoípios e convencões contábeis. 
2.2.1. O Processo de Escriturąãa Contábil

A Escrituração é a parte da Contabilidade responsável pelo registro ou représentacão gráfica de todos os atos e fatos ocorridos na gestão de uma empresa. Como será visto adiante, as anotações podem ser feitas em livros contábeis ou mesmo extracontábeis.

O processo de escrituração diz respeito à maneira de arquivar ou executar os registros das transações da empresa por meio de livros, fichas, acumuladores de máquinas de calcular, discos e fitas magnéticas. Sua escolha depende das caracteristicas da entidade e do volume e complexidade de seus registros, podendo recair sobre processos tradicionais, como o manual e o maquinizado, ou então optar pelo processo mecanizado ou o eletrônico (computadorizado), dentro da tendência atual de informatização das empresas.

O processo de escrituração adotado determina tanto a qualidade e confiabilidade das informações, quanto a rapidez em que são obtidas.

Todos os modelos das instituiç̃es públicas brasileiras adotam o processo manual de escrituração. Acredita-se que essa opqão seja um dos fatores responsáveis pelo insucesso dos vários programas de Contabilidade implantados no passado por essas instituições, pelas razões já apontadas.

8/ Este item está baseado, principalmente, na seguinte literatura: ANGELICO (1982); ARMBRUSTER (1983); BIO (1985); IUDICIBUS et alii (1983); SILVA (1971). 
A titulo de ilustracão, o autor deste trabalho presenciou a apresentacão, por um extensionista rural, dos resultados comparativos da Contabilidade de um conjunto de propriedades, sete meses após o término do ano agricola. Pôde-se observar, na ocasião, relativo desinteresse por parte dos produtores.

Isso não significa que o processo de escrituracão manual esteja fadado ao insucesso. Entretanto, quando se trabalha com grupos de empresas, como é o caso dos Servicos de Extensão estatais, e o sistema contábil deixa seu caráter fiscal para se tornar um instrumento de auxilio à tomada de decisão da empresa, certamente o processo de escriturąão manual deve ceder lugar ao computadorizado.

Os modelos que seguem os dispositivos da Lei adotam os mais diversos processos de escrituracão: manual, maquinizado, mecanizado, computadorizado e misto. MARION (1985b), por exemplo, recomenda o processo computadorizado para seu modelo.

2.2.2. 0 Periodo Contábil

As informações geradas pelo sistema contábil devem ser fornecidas a intervalos regulares de tempo, normalmente com a duração de um ano, podendo coincidir ou não com o ano-calendário. Entretanto; dependendo das caracteristicas e interesses da empresa, é possivel utilizar-se un periodo de diferente duracão.

9ste item está baseado, principalmente, na seguinte
literatura: IUDICIBUS et alii (1983); JAMES \& STONEBERG
(1980); MARION (1985b). 
Para fins de administração econômico-financeira, o periodo contábil deve ser o intervalo de tempo mais significativo para a análise das atividades de produção da empresa, ou seja, deve situar-se entre o inicio e o fim de un ciclo, abrangendo todo o fluxo de entradas e saidas de recursos dos empreendimentos (ciclo operacional).

O esquema abaixo ilustra o conceito do periodo contábil (JAMES \& STONEBERG, 1980).

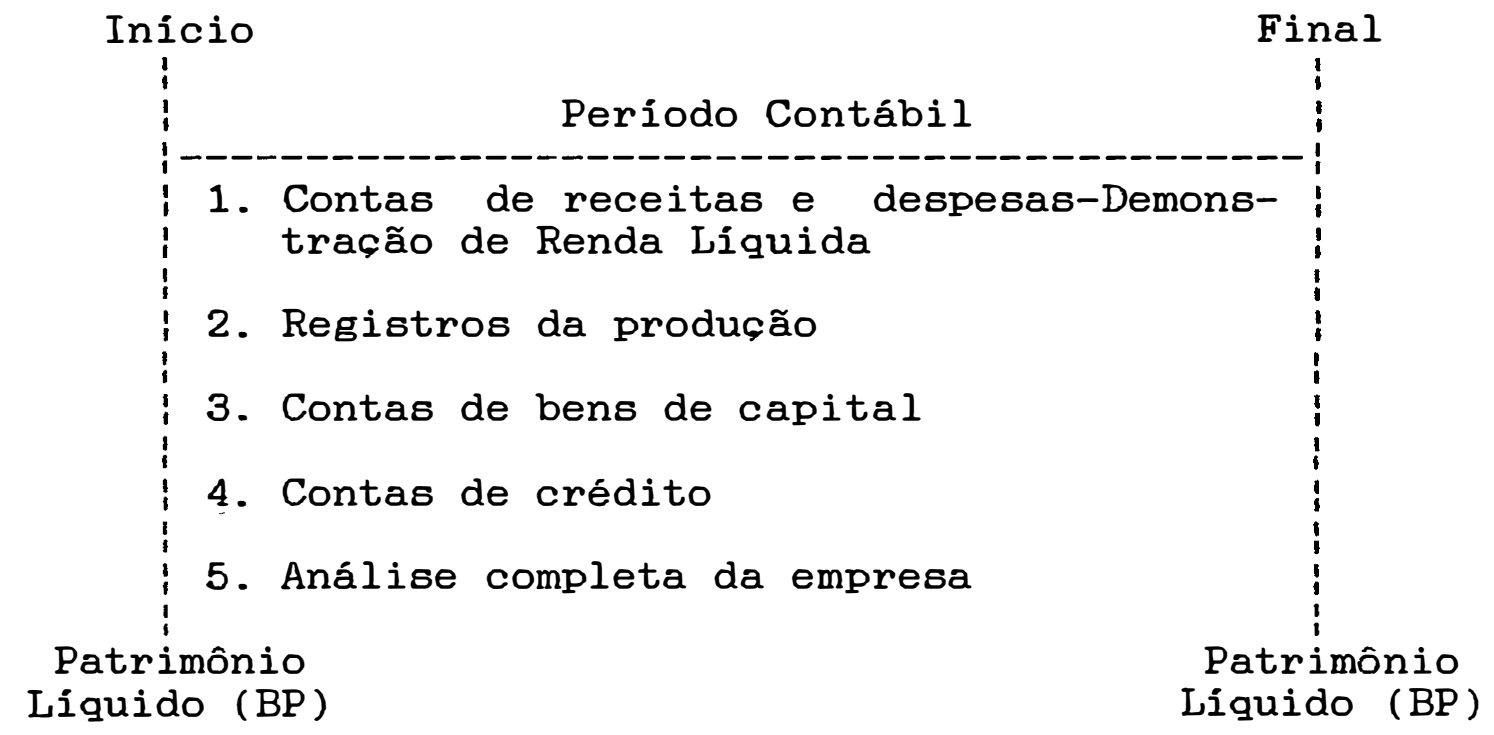

Figura 3. O período contábil

Observa-se que esse periodo é marcado por fatos e transações que alteram o Patrimônio Liquido da empresa, como: receitas e despesas, variações na produção, variações nos preços dos bens, compras e vendas de bens de capital, pagamentos de obrigações, contração de novas dividas, etc..

Uma vez selecionado o período contábil mais adequado à empresa em questão, deve-se procurar mantê-lo de tal modo que se 
tornem válidas as análises comparativas entre periodos.

A maioria dos modelos estudados utilizam ou recomendam - ano agrícola como periodo contábil. Para as regiões Sul e Sudeste, ele tem inicio normalmente em Setembro de um determinado ano, terminando em Agosto do ano seguinte.

2.2 .3 O Regime Contábil 10/

A escrituracão da empresa pode adotar, basicamente, dois tipos de regimes contábeis: o Regime de Caixa e o Regime de Competência.

\section{Regime de Caixa}

Recebe essa denominąão porque registra apenas transações que envolvem entradas ou saidas de dinheiro do Caixa, ou seja, só considera como receitas ou despesas aquelas efetivamente recebidas ou pagas dentro do periodo. Portanto, nesse regime não são registradas: as compras e vendas à prazo, a produção que entra em estoque e muitas outras receitas e despesas não-caixa.

Nesse caso, é o fluxo de dinheiro que determina o registro contábil. A receita é reconhecida quando há uma entrada no Caixa e a despesa, quando há desembolso de Caixa.

\footnotetext{
10/ Esse item está baseado, principalmente, na seguinte literatura: ANGELICO (1982); ARMBRUSTER (1983); FROGOLI (1977); IUDICIBUS et alii (1983); JAMES \& STONEBERG (1980); MARION (1986); SCOTT JR. (1977).
} 


\section{Regime de Competência}

Esse regime considera como receitas e despesas de um periodo aquelas que the competirem, não importando se tenham sido recebidas ou pagas nesse periodo, ou seja, que tenham implicado em transações em dinheiro. Portanto, o registro das operações leva em conta o momento de ocorrência do fato gerador da receita ou despesa e não a movimentacão do Caixa. Assim sendo, são registradas tanto as transações em dinheiro à vista (caixa), quanto à prazo e outras transacões implicitas que não envolvem variacões do Caixa (não-caixa).

\section{Regime Hibrido}

Ambos os regimes, de Caixa e de Competência, apresentam suas vantagens e desvantagens. O Regima de Caixa é mais fácil de operar porque requer menos lancamentos no Livro Diário. Em contrapartida, o Regime de Competência requer lancamentos adicionais para ajustes, mas proporciona maior exatidão nos resultados, que não é obtida no Regime de Caixa. Assim sendo, o Regime Hibrido procura associar a facilidade de operacão e maior economia fiscal do Regime de Caixa com a exatidão do Regime de Competência (ARMBRUSTER, 1983).

E importante lembrar que não se deve confundir os métodos de lancamentos por Partidas Simples e Partidas Dobradas com os regimes contábeis de Caixa, de Competência e Híbrido.

O Método de Partidas Dobradas pode adotar qualquer um dos três regimes. ARMBRUSTER (1983), por exemplo, propõe 
lançamentos por Partidas Dobradas e com Regime Híbrido, isto é, as receitas e despesas não-caixa somente aparecem no $B P$, não sendo computadas no cálculo da Renda Líquida do Período, que reconhece apenas as receitas e despesas em dinheiro.

Já o Método de Partidas Simples, normalmente adota o Regime de Caixa, mas podem ser encontradas variaçoes como ocorre, por exemplo, com os modelos de Contabilidade Rural norteamericanos. Estes adotam o Regime de Caixa, realizando ajustes no final do periodo contábil, de forma a apropriar as receitas e despesas não-caixa que competem ao período em questão, como por exemplo, alterações nos valores de Contas a Pagar e Contas a Receber (FREY \& KLINEFELTER, 1978).

Os modelos de algumas das instituiøões públicas (CATI, EMATER - RGS, IEA, VICOSA), embora baseados nos sistemas americanos, não usam exatamente o mesmo procedimento, ou seja, o de adotar o Regime de Caixa, durante o ano agrícola, com ajustes posteriores.

Por exemplo, o modelo da CATI (CATI, 1980) recomenda que todas as despesas à prazo sejam registradas como se fossem à vista, obedecendo ao Regime de Competencia. Essa alternativa, entretanto, pode levar a erros de duplicação dos registros porque não existe controle da Conta Caixa, como no Método das Partidas Dobradas. Uma vez que houve Compra à Prazo e registro de Despesa à Vista e Contas a Pagar pode ser que, nas futuras liquidacões desse débito, volte-se a registrar essa Despesa, distorcendo os resultados. 
Como foi citado anteriormente, o ajuste referente à variacão dos estoques de insumos para se obter o valor do insumo usado durante o período, não está indicado com clareza nos "Cadernos" de alguns modelos brasileiros.

2.2.4. A Forma de Lancamento

A escrituracão dos fatos e transações que movimentam a empresa é feita de uma forma convencional denominada lancamento. Essa forma é ditada praticamente por dois métodos: Método de Partidas Simples e Método de Partidas Dobradas.

Método de Partidas Simples (MPS)

O MPS dita uma forma de lancamento em que cada transação é registrada apenas uma vez, figurando, de modo geral, a receita ou a despesa. Organiza uma espécie de histórico das transacões financeiras que envolvem pagamentos e recebimentos à vista ou à prazo. São utilizadas apenas algumas contas como Caixa, Receitas e Despesas à Vista e à Prazo, Valores a Receber e Valores a Pagar, Devedores e Credores, etc. (FROGOLI, 1979). Dados auxiliares são obtidos através de inventários e controles das culturas, criacões, almoxarifado, etc..

Este método é, com algumas adaptações, o único utilizado nos sistemas de Contabilidade Rural de nossas instituicões públicas. Nos Estados Unidos é muito usado pela

11 Esse item está baseado principalmente na seguinte literatura: ANGELICO (1982); ARMBRUSTER (1983); FRJGOLI (1977); IUDICIBUS et alii (1983); MARION (1986); SILVA (1971). 
Extensão Rural das universidades.

Método de Partidas Dobradas (MPD)

O MPD é fundamentado no principio de que "não há devedor sem credor" e vice-versa. A base desse método é a conta. Assim, o registro de qualquer operąão implica que a cada débito em uma ou mais contas deve corresponder um crédito equivalente em uma ou mais contas. Consequentemente, a soma dos débitos deverá ser igual à soma dos créditos, em perfeito equilibrio.

Portanto, diferentemente do MPS, o MPD dita um modo de lançamento em que cada transação é registrada, no minimo, duas vezes, na forma de débitos e créditos simultâneos e com valores iguais, mostrando a qualquer momento todas as ocorrências que se verificaram no patrimônio da empresa.

Todos os modelos desenvolvidos por profissionais de Contabilidade utilizam o MPD, como por exemplo o de VALLE (1983) e o de MARION (1985a e 1985b).

2.2.5. O Plano de Contas

As operações ocorridas na administração de uma empresa podem ser representadas através de titulos contábeis denominados contas.

As contas atuam como o veiculo básico dos dados sobre a

12/ Este item está baseado, principalmente, na seguinte literatura: ANGELICO (1982); IUDICIBUS et alii (1983); JAMES \& STONEBERG (1980); MARION (1985b) e (1986). 
situação patrimonial da entidade, ou seja, seus bens, direitos e obrigaç̃es; as alteracões sofridas nesse patrimônio em determinado periodo e as causas destas alteracões (receitas e despesas). Além disso, devem também representar os resultados obtidos durante o periodo analisado. Em suma, as contas são empregadas para registrar as causas e efeitos de todos os atos e fatos administrativos que movimentam a empresa.

Por outro lado, a função geral das contas é servir de instrumento para débito e crédito das transações, segundo o Método das Partidas Dobradas.

Há contas que representam uma única espécie de componente patrimonial (contas simples) e outras que identificam componentes diversos da mesma natureza (contas coletivas). Para facilitar sua identificação, cada conta deve receber um nome e um código numérico. Além disso, uma conta de caráter mais geral pode ser desdobrada em outras mais especificas, conforme a análise pretendida. Cada desdobramento denomina-se grau.

Plano de Contas é a estruturacão ordenada e sistematizada das contas usadas em uma entidade. F uma peca contábil de grande valor porque estabelece previamente a conduta a ser adotada na escriturąão dos fatos ocorridos na empresa.

Basicamente, o Plano de Contas é composto por uma relação de contas Patrimoniais ou Integrais e de Resultados ou Diferenciais, agrupadas segundo suas funcões. Também poderá ser complementado por instrucões que expliquem a sua composição e seu funcionamento, tais como (ANGELICO, 1982): 
a) descricão da funcão de cada conta, isto é, o que ela representa;

b) descrição do funcionamento das contas, ou seja, mecanismos de débito e crédito, relacionamentos entre contas, etc.;

c) fluxogramas gerais, mostrando as operações básicas e as contas utilizadas;

d) fluxogramas especiais, mostrando as operacões mais complexas, indicando os procedimentos e lancamentos;

e) instruções gerais e particulares sobre encerramento de contas e outras providências.

E importante esclarecer que uma empresa adota contas adequadas ao seu ramo de atividade e em função do seu modo de operar. Portanto, cada empresa deve elaborar seu próprio Plano de Contas de acordo com a natureza de suas atividades, sua forma de organização e constituicão juridica e sua dimensão patrimonial. Assim, dificilmente um Plano de Contas de uma empresa se ajustará perfeitamente à outra.

Entre os modelos estudados, apenas aqueles desenvolvidos dentro do Metodo das Partidas Dobradas sugerem um Plano de Contas (MARION, 1985a e 1985b; VALLE, 1983).

Mais recentemente, com o advento dos microcomputadores facilitando o emprego do MPD, os modelos norte-americanos de Contabilidade Rural passaram a apresentar também um Plano de 
Contas (JAMES \& STONEBERG, 1986).

2.2.6. Os Livros Contábeis ${ }^{13 /}$

A escrituração da empresa, isto é, o registro de suas operaços, é feito na forma de lançamentos em livros apropriados denominados Livros Contábeis.

No Método das Partidas Dobradas, a conta surge como o veículo básico para os lancamentos nos livros contábeis, que são organizados e classificados, de acordo com sua finalidade na escrituracão. Esses livros são: Livro Diário, Livro Razão, Livros Auxiliares do Razão e Balancete de Verificacão, que serão descritos e analisados no item Resultados.

Como foi visto, os registros pelo Método de Partidas Simples não são feitos, exatamente, em livros contábeis. São utilizados os chamados "Cadernos de Escrituração", cuja estrutura não é padronizada, variando conforme a instituição. De modo geral tais "cadernos" são organizados de forma a conter algumas "contas" genéricas (Caixa, Contas a Pagar e Contas a Receber, Receitas e Despesas, etc.), para elaboração dos demonstrativos no final do período.

13/ Esse item está baseado, principalmente, na seguinte literatura: ANGELICO (1982); ARMBRUSTER (1983); IUDICIBUS et alii (1983); MARION (1986); SILVA (1971). 
2.2.7. Contabilidade e Inflação

Certamente um dos fatores que mais prejudicam a eficácia de um sistema contábil, em qualquer empresa, é a presença da inflação. As flutuações do nivel geral de preços, com a consequente desvalorização da moeda, constituem um fenômeno crônico na economia brasileira e de muitos outros paises em desenvolvimento, fato esse que não pode ser desprezado pela Contabilidade.

Entretanto, dois dos "Principios Contábeis Geralmente Aceitos" negligenciam totalmente essa realidade ao considerar o custo histórico como base de valor ("Principio do Custo como Base de Valor") e admitir que o poder aquisitivo da moeda é constante ("Principio do Denominador Comum Monetário"). E evidente que a aplicação desses principios em condições de inflação acentuada, restringe completamente as possibilidades informativas da Contabilidade.

O nosso processo inflacionário é muito antigo e, até há algum tempo atrás, poucas medidas práticas haviam sido tomadas para tentar reduzir os efeitos distorcivos da inflação sobre a análise dos relatórios contábeis. Em 1964, a correção monetária tornou-se compulsória no Brasil. Todavia, mesmo com o advento da Lei das Sociedades Anônimas em 1976, estendendo a correção a todo - Ativo Permanente e Patrimônio Liquido, os seus resultados ainda apresentam problemas, devido à "mistura" de valores históricos e

14/ Este item está baseado, principalmente, na seguinte literatura: ANGELICO (1982); IUDICIBUS (1982); IUDICIBUS et alii (1983); MARION (1985b) e (1986); NORONHA (1987). 
corrigidos, dificultando as análises dos demonstrativos.

Esse fato ocorre porque o Artigo 185 da Lei No. 6404/76 não prevê a correcão dos Estoques e outros itens não-monetários do Ativo e Passivo Circulantes, como Contas a Receber, Contas a Pagar, Despesas Antecipadas e Resultados de Exercicios Futuros ( ANGELICO, 1982).

LIMA $^{15 /}$ (citado por IUDICIBUS, 1982) observa que o texto legal não esclarece qual a data a ser considerada para a correcão do custo histórico dos bens, nem a forma de correcão das alteracões no Patrimônio Liquido durante o período. Além disso, a obtencão do Lucro Liquido, com base no custo histórico, não reproduz o verdadeiro desempenho da empresa, devido ao acúmulo de valores de poder aquisitivo diferentes ao longo do periodo.

Outro elemento que não aparece no demonstrativo histórico refere-se às perdas não-realizadas nos itens monetários (Caixa, Bancos, Valores a Receber) que representam perdas de poder aquisitivo da moeda que permaneceu sem aplicacão durante o periodo inflacionário, além dos possiveis ganhos não-realizados com as Obrigações.

Assim sendo, a aplicação dos dispositivos legais leva à uma forma de correção monetária incompleta, gerando relatórios contábeis de dificil interpretação e pouca ou nenhuma utilidade para as tomadas de decisões gerenciais, bem como para os usuários

15 LIMA, I.S. As flutuacões de precos e seus efeitos nas demonstracões financeiras das empresas admitidas ao mercado de capitais. s.1. 1976. Tese de Mestrado. 
externos da Contabilidade (Bancos, Governo, etc.).

E importante lembrar que a Lei das Sociedades Anônimas e a legislação do Imposto de Renda permitem o uso de outros critérios para avaliacão de itens do Ativo, desde que melhorem a qualidade dos relatórios contábeis e sejam devidamente destacados em "Notas Explicativas" (Artigo 185, 40. Parágrafo- "Os estoques de mercadorias fungiveis destinadas à venda poderão ser avaliados pelo valor de mercado quando esse for o costume mercantil aceito pela técnica contábil"; ANGELICO, 1982).

Em consequência, surgiram na literatura brasileira diferentes propostas de avaliação patrimonial das empresas rurais, como a de MARION (1985b), que sugere a avaliąão dos estoques no Ativo Circulante a valores correntes de mercado, para que sejam devidamente reconhecidos os ganhos ou perdas economicamente ocorridos (isto é, sem realizacão financeira), e também sejam apropriadas as flutuações dos precos.

Porém, observa-se nessas propostas a falta de uma abordagem mais objetiva à respeito do problema inflacionário e seus reflexos sobre os demonstrativos e indicadores financeiros. Além disso, os critérios adotados para avaliação dos bens são pouco consistentes e provavelmente seriam alterados em função das circustancias. MARION (1985b p.136) por exemplo, propõe a "avaliacão do Ativo Permanente considerando o Custo Histórico Corrigido com a possibilidade de Reavaliacão; e para os demais itens do Ativo Circulante e Realizável a Longo Prazo, como são valores de menor significância em relação ao Ativo, e não há 
necessidade de um estudo mais acurado, aplica-se a avaliação pelo Custo Histórico como base de valor".

Nota-se, também, nessas propostas uma grande preocupação em adotar medidas que proporcionem o máximo de economia fiscal aos resultados gerados pelo sistema contábil. Assim, adotar-se-ia o método do Custo Histórico como base para avaliação dos estoques e desse modo evitar-se-ia uma possivel antecipacão de receitas, com o consequente aumento do lucro tributável (MARION, 1985b). Entretanto, esse é um objetivo conflitante com a finalidade da Contabilidade de prover os usuários com informacões úteis às tomadas de decisões. FRUGOLI (1977 P.16) analisando os principais objetivos da Contabilidade, faz uma ressalva de que "os relatórios contábeis que são pautados em um sistema contábil de informações regido por delimitaçoes de ordem fiscal, e não por critérios de realidade, trazem em si, viéses de difícil mensuração e correcão".

Portanto, para que a análise dos relatórios contábeis seja realmente objetiva e eficiente é necessário que todos os itens do Balanço Patrimonial e da Demonstração do Resultado do Exercicio estejam expressos em poder aquisitivo de uma mesma data.

Com o objetivo de conferir maior consistencia aos demonstrativos financeiros, expurgando-os da variável inflacionária, IUDICIBUS et alii (1983) relaciona uma série de questões que devem ser resolvidas:

a) que tipo de valor se pretende obter; 
b) qual o grau de detalhamento para o ajustamento dos registros originais;

c) como proceder (qual deflator utilizar, quais a técnicas para ajustar certos itens do Balanço, etc.);

d) como interpretar os valores e demonstrativos resultantes.

Alguns dos modelos estudados trabalham com valores reais, usando como deflatores indices de precos (ACARESC, 1986) ou transformando os valores nominais em número de OTN e mais recentemente BTN (EMATER, 1987).

E oportuno ressaltar que a literatura sobre esse assunto é bastante escassa, principalmente para o setor rural. 0 mesmo ocorre com a literatura estrangeira, considerando que a Contabilidade Rural é mais desenvolvida justamente naqueles países sem problemas inflacionários.

\subsection{Principios e Convenõos Contébejo $16 /$}

Constituem um conjunto de normas, regras e postulados, que foram desenvolvidos e compilados ao longo dos anos, por entidades profissionais, a partir da anslise e observação dos fenômenos contábeis, levando em conta as condições econômicas, sociais e institucionais de cada época.

16/ Esse item está baseado, principalmente, na seguinte literatura: FRUGOLI (1977); IUDICIBUS (1982); IUDICIBUS et alii (1983); JAMES \& STONEBERG (1980). 
Tais entidades profissionais referem-se a entidades de classe, agências governamentais, comissões especiais de conferências e convencões internacionais que observam as caracteristicas do sistema contábil chegando à conclusões sobre seu funcionamento. Se geralmente aceitas pela classe contábil, essas conclusões tornam-se principios e convenç̃es que são codificados e divulgados, para que orientem a producão dos relatórios e toda a prática contábil, inclusive os processos de auditoria (IUDICIBUS et alii, 1983).

Esses principios e convengões evoluem e devem se adaptar às novas condições econômicas, institucionais e sociais. Entretanto alguns deles, já sem validade atual, continuam sendo aceitos "mais por tradição e conservadorismo" da classe contábil (por exemplo : Principios do Custo Histórico como Base de Valor, do Denominador Comum Monetário, da Realização da Receita, Convenção do Conservadorismo).

Não existem principios criados aqui, no Brasil, e sim normas da legislacão fiscal que não constituem princípios geralmente aceitos.

FRUGOLI ( 1977 ) destaca que algumas entidades contábeis brasileiras publicam literaturas especializadas com base em principios e convenções contábeis geralmente aceitos em. outros paises e traduzidos para o português, sendo adotados nos pareceres de auditores brasileiros, em relatórios financeiros publicados pela nossa imprensa.

Para se tornar "geralmente aceito", o principio ou 
convencão precisa ser reconhecido pelo consenso profissional como:
a) útil (relevante);
b) objetivo e
c) praticável.

Entretanto, os contabilistas têm dado maior importância à praticabilidade e objetividade do que à utilidade (ou relevância). Assim, qualquer processo associado a um maior grau de dificuldade em sua execucão, é considerado impraticável e menos objetivo. Esse fato tem restringido o progresso da teoria contábil na busca de maior precisão em seus resultados. Ocorre, por exemplo, com os processos de ajustamento dos relatórios contábeis históricos na presença de inflacão e com a avaliacão dos elementos patrimoniais pelo preso de mercado, ao invés do custo histórico.

Se a questão da praticabilidade for analisada mais pelo enfoque da relação custo-beneficio do que pelo lado da dificuldade de aplicacão, será possivel viabilizar uma série de processos coerentes com a realidade atual (isto é, relevantes) e assim desenvolver um sistema contábil mais voltado às reais necessidades do empresário do que à uma politica contábil retrógrada 17

17/ Para maiores detalhes consultar Quadro Sinótico dos Principios e Convencões Contábeis Geralmente Aceitos (p.263) de autoria de IUDICIBUS et alii (1983). 


\section{RESULTADOS E DISCUSSAO}

Este capitulo tem como objetivo apresentar um Modelo de Contabilidade Rural tomando como base a análise critica dos modelos estudados e as sugestões mencionadas no capitulo anterior. Assim, em primeiro lugar é proposto um conjunto de informações relevantes atendendo aos padrões desejados para a análise econômica do desempenho da empresa agropecuária, como um todo, e de suas principais atividades produtivas. Em seguida descrevem-se as alternativas adotadas para orientar 0 funcionamento de seu sistema contábil.

\subsection{Informações Geradas pelo Sistema Contábil}

Como foi explicado anteriormente, esta pesquisa irá propor uma profunda reestruturação das formas já consagradas de relatórios contábeis e seus respectivos indicadores financeiros e econômicos, com o objetivo de adequá-las às necessidades gerenciais da empresa rural, conforme descrito a seguir.

\subsubsection{Balanco Patrimonial (BP) ou Demonstrąão do Patrimônio Liquido}

O modelo de Balanço Patrimonial proposto tem como base a estrutura geral padronizada pela Lei das Sociedades Anônimas (No. 6404/76) (ANGELICO, 1982; IUDICIBUS et alii, 1983; MARION, 1986). E exposto na forma de "seç̃es sobrepostas" com o Ativo na parte superior e o Passivo na inferior, como pode ser visto na Tabela 4. As alterąões nessa estrutura referem-se, primeiramente, à denominação e subdivisão dos agrupamentos de 
Tabola 4. Modelo Proposto de Balanco Patrimonial

EMPRESA RURAL :

DATA:

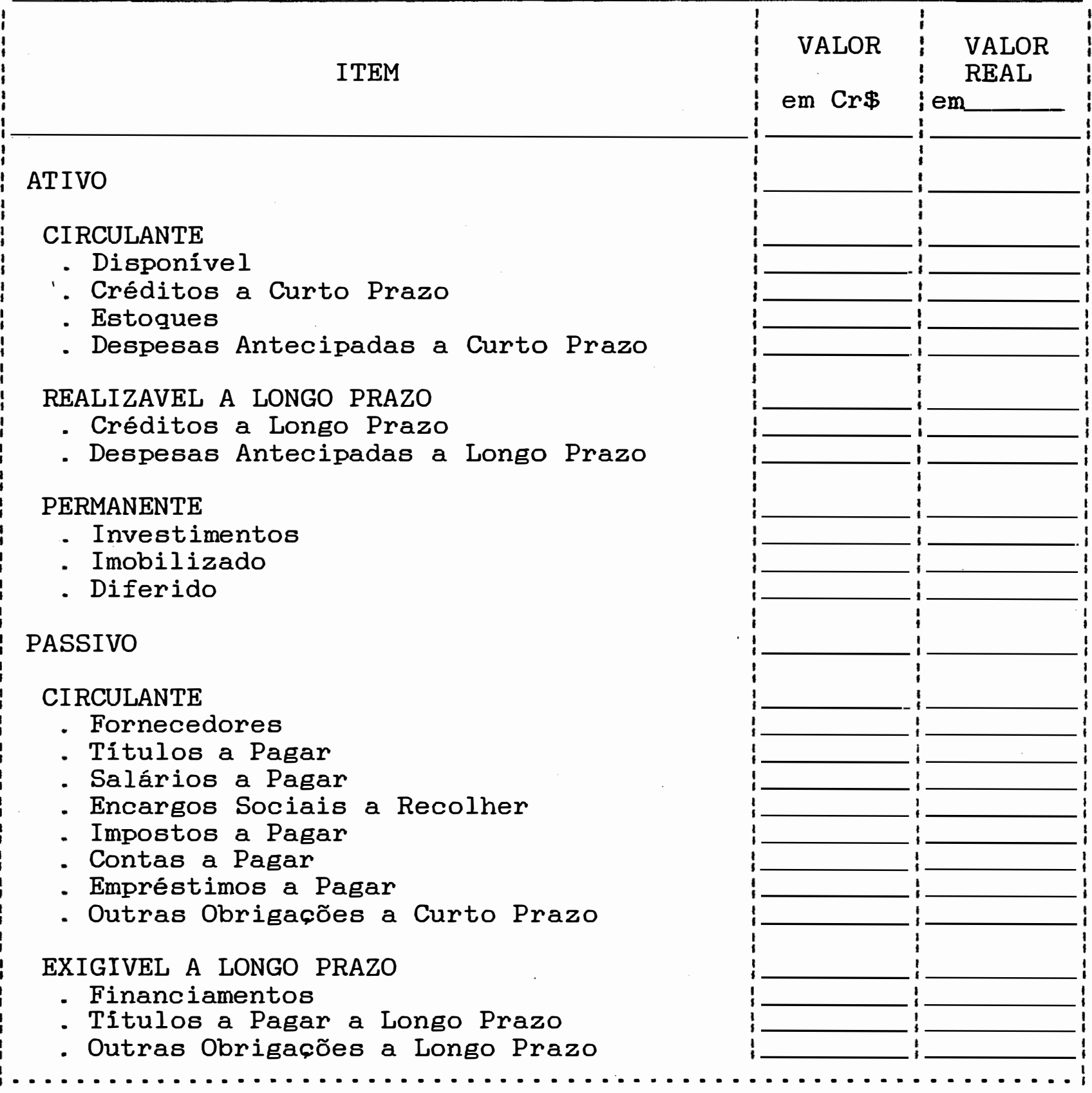

(continua) 
Tabela 4. Modelo Proposto de Balanço Patrimonial (continuação) EMPRESA RURAL :

DATA :

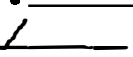

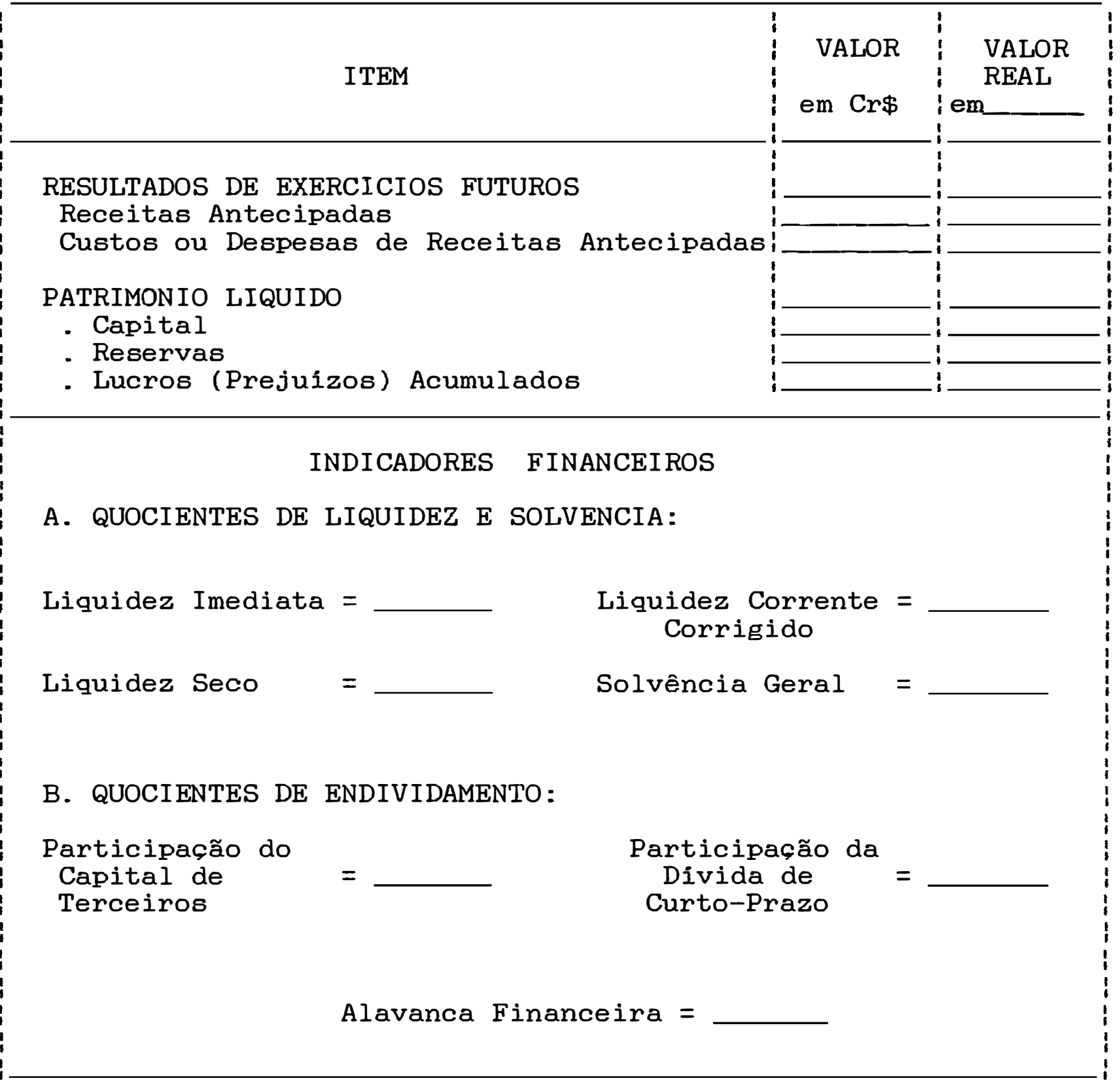

contas de quarto e quinto graus apresentados no Elenco de Contas Completo. Além disso, o BP apresenta duas colunas, sendo que a primeira mostra valores em $\mathrm{Cr} \$$ da data do levantamento do Balanqo - a segunda registra valores reais conforme o tipo de deflator 
escolhido pelo usuário.

Em seguida são descritos os principais componentes do Balanco Patrimonial proposto.

\section{Ativo}

o Ativo é o componente positivo do patrimônio da empresa e compreeende todos os seus bens tangiveis e intangiveis. Tangiveis são todos os bens imóveis (terras, construgões, plantacões, etc.) e bens móveis (veiculos, maquinaria, animais, etc.). Intangiveis são todos os direitos, ou seja, os bens sob os quais a empresa exerce dominio mas que estão sob a posse de terceiros (Contas a Receber, Titulos a Receber, etc.). Tais bens serão entregues à empresa em datas estipuladas previamente.

Os itens do Ativo são classificados segundo grau crescente de dificuldade para serem convertidos em dinheiro, ou seja, em ordem decrescente de liquidez. Assim, o nome de cada grupo de contas indica o tempo necessário à empresa para transformar seus ativos em dinheiro, de acordo com suas intenções.

Os grupos de contas do Ativo såo:

\section{Ativo Circulante}

Inclui itens com liquidez imediata em dinheiro mais os bens e direitos que podem ser vendidos, consumidos ou realizados aos precos em vigor no mercado, no curto prazo, isto é, no período máximo de um ano. Compreende os seguintes sub-grupos : 
Disponivel - registra o dinheiro imediatamente disponivel em Caixa, conta corrente nos Bancos e na forma de aplicacões no Mercado Financeiro (Open Market, Overnight, etc.).

Créditos a Curto Prazo - são os créditos realizáveis no prazo de um ano e representados por Titulos a Receber, Contas a Receber, Adiantamentos e Empréstimos e Aplicąões Financeiras de Curto Prazo (CDB, Fundo de Renda Fixa, etc.).

Estoques - abrange os estoques da produção na forma de culturas anuais em crescimento, culturas perenes em manutencão, produtos agricolas acabados, animais em crescimento, produtos animais e os estoques de insumos e materiais de consumo. Devido à sua elevada liquidez, os animais reprodutores também devem ser incluídos nesse grupo. Além disso, esse procedimento facilita o levantamento do estoque de animais dos rebanhos pelos usuários do Modelo proposto. O mesmo ocorre com os animais de trabalho comprados para servirem determinadas atividades de producão animal, como será explicado adiante.

Despesas Antecipadas a Curto Prazo - registra os pagamentos antecipados de despesas (seguros, juros, aluguéis, etc.) apropriáveis apenas no periodo seguinte.

Ativo Realizável a Longo Prazo

Compreende ativos que serão convertidos em dinheiro mais lentamente, em prazo superior a um ano. Seus sub-grupos são os seguintes: 
Créditos a Longo Prazo - são os créditos realizáveis no decorrer de exercicios subsequentes ao exercicio seguinte e representados por Titulos a Receber, Contas a Receber, Adiantamentos e Empréstimos e Aplicacões Financeiras de Longo Prazo.

Despesas Antecipadas a Longo Prazo - registra os pagamentos antecipados de despesas apropriáveis somente nos períodos subsequentes ao periodo seguinte.

\section{Ativo Permanente}

Inclui itens de menor grau de liquidez, com maior dificuldade para serem convertidos em dinheiro porque são adquiridos ou produzidos sem a intencão de comercializacão, pelo menos durante um periodo superior a um ano. A venda desses ativos acarreta, via de regra, o encerramento das atividades da empresa.

Compreende os seguintes sub-grupos:

Investimentos - são recursos aplicados com a finalidade de gerar renda em caráter permanente, mas sem o objetivo de manter as atividades operacionais da empresa. Inclui as Participacões em Outras Empresas e em Fundos de Investimento, os Imóveis para Renda ou Futura Utilização, etc..

Imobilizado - abrange os ativos de natureza permanente com vida útil relativamente longa, destinados à manutencão das atividades operacionais da empresa. No BP proposto esse sub-grupo aparece dividido em Intermediário, Fixo, Em Andamento e Depreciacão Acumulada, para que a classificacão desses bens seja mais coerente 
com o nivel de facilidade para a venda e o seu valor relativo para a empresa rural.

Assim, no Imobilizado Intermediário são incluidos aqueles bens que podem ser vendidos com certa facilidade em um prazo médio: Veiculos, Maquinaria, Equipamentos e Implementos, Móveis e Utensilios. Os animais reprodutores e de trabalho, pelas suas caracteristicas de bens de capital, são integrantes do Ativo Imobilizado, entretanto, devido à sua alta liquidez, esses ativos foram classificados como Estoques.

Já no Imobilizado Fixo são classificados itens com pouca liquidez: Terras, Construcões, Instalacões, Melhoramentos e Culturas Perenes Formadas.

A conta Depreciação Acumulada registra as depreciações desses itens ao longo de sua vida útil. Seu saldo aumenta à medida que o valor contábil real do ativo vai diminuindo devido ao desgaste ou obsoletismo (Controle de Ativo Imobilizado - item 3.1.6.).

O Imobilizado em Andamento apropria gradativamente, ao longo dos periodos contábeis, os gastos para construcão ou formacão de determinados bens de capital produzidos pela empresa. Tais gastos são ativados nas contas: Construcões em Andamento, Instalações em Andamento, Melhoramentos em Andamento e Culturas Perenes em Formação.

Diferido - registra as "aplicacões de recursos em despesas que contribuirão para a formacão do resultado de mais de um exercicio 
social" (Gouveia, 1982 p.88). Inclui os Gastos de Implantacão e Pré-Operacionais, Estudos e Projetos, Melhorias, etc..

A conta Amortizacão Acumulada apropria gradativamente as amortizações dos gastos ativados no Imobilizado Diferido. Seu saldo vai aumentando ao passo que o valor desse ativo diminui durante o periodo estimado em que ele traz beneficios à empresa.

Passivo

O Passivo é constituido pela soma das Obrigacões (Passivo Exigivel) com o Patrimônio Liquido. As Obrigaçõs representam o componente negativo do patrimônio e compreendem todos os compromissos assumidos pela empresa em suas transacões com terceiros e que devem ser quitados em datas previamente convencionadas. São bens que se encontram sob a posse da empresa, mas cujo domínio é de terceiros (Contas a Pagar, Títulos a Pagar, Empréstimos, Financiamentos, etc.).

O Patrimônio Liquido representa os compromissos da empresa para com o(s) empresário(s) ou proprietário(s).

Assim sendo, o Passivo mostra as fontes de capital da empresa, isto e, capital próprio (Patrimônio Liquido) e capitais alheios (Obrigações), enquanto o Ativo apresenta as aplicações desses capitais em determinado momento.

Os itens do Passivo Exigivel são classificados segundo uma escala decrescente de urgência em que as Obrigações assumidas pela empresa deverão ser cumpridas. Dessa forma, a denominacão de 
cada grupo de contas indica o tempo exigido para a empresa liquidar seus compromissos.

Os grupos de contas do Passivo Exigivel são:

Passivo Circulante

Inclui as contas de obrigacões que deverão ser pagas rapidamente no curto prazo, isto é, no decorrer do periodo máximo de um ano a partir da data do Balanco. Compreende os seguintes sub-grupos:

Fornecedores - registra as compras à prazo de produtos agricolas, animais, produtos animais, insumos e materiais de consumo.

Titulos a Pagar - são as dividas de curto prazo representadas por documentos como duplicatas, promissórias, etc..

Salários a Pagar - inclui os salários e ordenados ainda não pagos ao pessoal administrativo, mão-de-obra permanente e temforária e terceiros.

Encargos Sociais a Recolher - são as despesas decorrentes da folha de pagamento, que ainda não foram pagas (INPS, FGTS, 130. Salário, etc.).

Impostos a Pagar - registra os impostos sobre as vendas, serviços, renda, propriedade e outros que ainda não foram pagos ( ICM, ISS, IR, ITR, etc.).

Contas a Pagar - são as dívidas de curto prazo não representadas por qualquer documento oficial de débito como contas de energia 
elétrica, água, " telefone, etc., não incluidas nos sub-grupos anteriores.

Empréstimos a Pagar - inclui os empréstimos realizados junto às instituicões financeiras a serem pagos dentro de um ano. Referemse, normalmente, ao crédito para custeio das atividades operacionais da empresa rural e as parcelas dos financiamentos de longo-prazo venciveis no periodo em questão.

Outras Obrigacões de Curto Prazo - registra outros tipos de dividas, menos significativas, não incluidas nos sub-grupos anteriores.

Passivo Exigivel a Longo Prazo

Compreende as obrigações que deverão ser pagas em um prazo mais longo, superior a um ano. Isto é, são as dividas venciveis nos periodos subsequentes ao periodo seguinte. Seus sub-grupos são:

Financiamentos - registra os empréstimos realizados junto às instituicões financeiras, com mais de um ano de prazo para serem pagos. Referem-se, normalmente, ao crédito para investimentos no Ativo Permanente da empresa rural.

Titulos a Pagar a Longo Prazo - inclui as dividas de longo prazo representadas por documentos como duplicatas, promissórias, etc..

Resultados de Exercicios Futuros

Inclui as receitas recebidas antecipadamente, sem 
riscos de devolução e que contribuirão para a formacão de resultados de periodos futuros. Compreende os seguintes subgrupos:

Receitas Antecipadas - representam os recebimentos antecipados, antes da data previamente estipulada. Por exemplo: aluguéis antecipados.

Custos ou Despesas das Receitas Antecipadas - são todos os custos e despesas diretamente relacionados com as receitas antecipadas e que devem ser, delas, subtraidos.

Patrimônio Liquido

"O Patrimônio Liquido representa o registro do valor que o(s) proprietário(s) de uma empresa tem aplicado no negócio" (GOUVEIA, 1982 p.10). Esse montante é proveniente de investimentos efetuados pelo(s) proprietário(s) no capital da empresa, dos lucros ou prejuizos resultantes de suas atividades operacionais e de outros ganhos que eventualmente possam ocorrer.

Propõe-se que os sub-grupos de contas componentes do Patrimônio Liquido sejam simplificados da seguinte forma:

Capital - representa o investimento realizado na empresa pelo(s) seu(s) proprietário(s) na forma de recursos financeiros ou materiais.

Reservas - equivalem à separacão de parcelas provenientes de ganhos, com o objetivo de preservar o Patrimônio Liquido de uma empresa, para que ela possa continuar operando e se expandindo 
(GOUVEIA, 1982 ).

Neste Modelo, será utilizada apenas a Reserva de Reavaliacão que é uma contrapartida para a atribuicão de valores atualizados a itens do Ativo Permanente. Essa reserva representa um ganho contábil (não-realizado financeiramente) que aumenta o Patrimônio Liquido da empresa.

Lucros ou Prejuizos Acumulados - representam os lucros retidos remanescentes, isto é, não distribuidos aos proprietários nem canalizados para aumento do capital ou formacão de reservas (MARION, 1986). E uma conta que interliga o BP à DRE porque incorpora o Lucro Liquido do periodo.

Avaliação dos Elementos Patrimoniais

Para atender às finalidades gerenciais deste Modelo, a avaliacão dos elementos patrimoniais não se restringirá aos dispositivos da Lei que determinam a tão criticada prática do eusto histórico nominal, segundo os "Principios e Convenç̃es Contábeis Geralmente Aceitos". Neste trabalho, procurou-se contornar tal problema através do uso de valores reais na avaliação desses componentes patrimoniais, como será explicado no item 3.3.10. (O Tratamento da Inflação pelo Sistema Contábil).

De forma sucinta, os critérios para avaliacão dos elementos do Ativo são os seguintes:

\section{Circulante}

Disponivel - pelo valor corrente da moeda e dos documentos na 
data do balanço e também pelo número de BTN, US\$, ou outra unidade monetária, em funcão do deflator escolhido. Tratando-se de moeda estrangeira, pelo custo de aquisicão em moeda nacional atualizado pela taxa de câmbio na data do Balanço.

Créditos - pelo valor dos direitos atualizados segundo as cláusulas contratuais de correcão monetária e juros, deduzidas as possíveis perdas (Provisão para Devedores Duvidosos).

Estoques - pelo preco de mercado (custo de reposicão) e pelo custo real de aquisicão, producão, formacão ou manutencão. Neste Modelo, recomenda-se que os animais reprodutores sejam avaliados pelo preco de mercado. Esse procedimento é justificado pelo fato de que seria pouco prático identificar, nas diferentes criacões, quais são os animais reprodutores comprados, passiveis de depreciação, e quais são aqueles produzidos pela empresa. Maiores detalhes serão evidenciados no item Controle de Estoques $(3.1 .6$.$) .$

Despesas Antecipadas a Curto Prazo - pelo valor real pago antecipadamente deduzida a apropriacão até a data do Balanco.

\section{Realizável a Longo-Prazo}

Créditos - pelo valor dos direitos atualizados segundo as cláusulas contratuais de correcão monetária e juros, deduzidas as possiveis perdas (Provisão para Devedores Duvidosos).

Despesas Antecipadas a Longo Prazo - pelo valor real pago antecipadamente deduzida a apropriacão até a data do Balanco. 
Permanente

Investimentos - pelo custo histórico de aquisição deflacionado, ou seja, corrigido para a data de levantamento do balanco, deduzidas as perdas prováveis na realização do seu valor (Provisão para Perdas em Investimentos).

Imobilizado - pelo custo histórico de aquisicão ou producão deflacionado deduzido o valor da Depreciaça Acumulada até a data do Balanço.

Quando houver defasagem significativa entre o custo histórico deflacionado e o valor de mercado do ativo, poderá ser efetuada uma Reavaliação atribuindo-se um novo preço de mercado ao item em questão. Isso ocorre particularmente com imóveis, quando apresentam uma valorização superior à taxa inflacionária.

Diferido - pelo custo histórico de produção deflacionado, deduzido o valor da Amortização Acumulada até a data do Balanço.

Os critérios para avaliação dos elementos do Passivo são os seguintes:

Passivo Circulante e Exigivel a Longo-Prazo - pelo valor das obrigações, corrigido monetariamente e apropriando o valor dos juros, segundo suas cláusulas contratuais. Tratando-se de obrigações em moeda estrangeira, utiliza-se a taxa de câmbio da data do Balanço para expressá-las em moeda nacional.

Receitas Antecipadas - pelo valor real das receitas na data do Balanço, deduzidos os custos e despesas a elas correspondentes. 
Patrimônio Liquido - pelo valor real de seus comfonentes: Capital, Reservas, Lucros (ou Prejuizos) Acumulados.

\section{Indicadores Financeiros}

São quocientes calculados a partir dos dados de cada Balanço Patrimonial e indicam a posição financeira da empresa sob vários angulos alternativos. Fornecem informações adicionais àquelas obtidas diretamente do Balanço e de forma mais objetiva. Neste Modelo serão usados os seguintes indicadores:

\section{Quocientes de Liquidez}

A liquidez de uma empresa mede a sua capacidade de gerar recursos convertendo itens do seu Ativo em dinheiro ou obtendo novos empréstimos, com a finalidade de saldar suas Obrigaç̃es mais urgentes a atender situações imprevistas ou oportunidades de novos investimentos.

Liquidez Imediata: indica a quantia de dinheiro
disponivel em Caixa e conta corrente nos Bancos
(Disponibilidades) para saldar cada cruzeiro das dividas de curto prazo, isto é, as Obrigações para com terceiros que devem ser liquidadas dentro do período contábil subsequente à data do Balanço.

Liquidez Imediata $=\frac{\text { Caixa }+ \text { Bancos }}{-} \frac{-1 .-1}{\text { Passivo Circulante }}$

Esse indicador não acrescenta muito à análise dos negócios agropecuários, uma vez que não considera justamente os 
itens de pequena magnitude no Ativo Circulante (Valores a Receber, Despesas Antecipadas) ou que não representam grandes riscos de mercado (Estoques) (BAKER, 1979).

Liquidez Seco: uma vez que, para empresas não-rurais, a conversibilidade em Caixa dos Estoques está associada a um certo grau de risco, criou-se o quociente de liquidez seco, que subtrai os Estoques do Ativo Circulante.

Liquidez Seco $=\frac{\text { Ativo Circulante }- \text { Estoques }}{\text { Passivo Circulante }}$

Esse indicador também não é tão relevante para empresas rurais, já que os estoques de animais e outros produtos agropecuários apresentam períodos de venda razoavelmente previsiveis e mercados bem estabelecidos (BAKER, 1979).

Liquidez Corrente: indica a quantia de dinheiro disponivel em Caixa e Bancos mais o que pode ser convertido em dinheiro no curto prazo (Valores a Receber e Estoques), para saldar cada cruzeiro das Obrigacões de Curto Prazo.

Liquidez Corrente $=\frac{\text { Ativo Circulante }}{\text { Passivo Circulante }}$

Pelas razóes expostas acima, esse é considerado o quociente de liquidez mais importante para a análise da empresa agropecuária.

Liquidez Corrente Corrigido: considerando-se que a venda dos animais reprodutores da empresa pode acarretar o 
encerramento de determinadas atividades pecuárias, sugere-se a apuração do quociente de liquidez corrente corrigido, que subtrai do Ativo Circulante apenas os Estoques de Animais Reprodutores. Esses bens mostram elevada representatividade no Circulante e são responsáveis pela continuidade produtiva da empresa.

Ativo Circulante $-\begin{gathered}\text { Estoque de } \\ \text { Reprodutores }\end{gathered}$
Passivo Circulante

Entretanto, como foi dito anteriormente, não há na literatura nenhuma fonte que informe padrões de indicadores para a empresa rural brasileira.

Nos Estados Unidos, a razão $2: 1$ é frequentemente adotada como padrão mínimo aceitável para o quociente de Liquidez Corrente, embora possa ser um valor muito alto para propriedades de grande porte. Por outro lado, uma razão abaixo de 1:1 só poderia ser aceita em circunstâncias muito especiais.

A tendência desse indicador no tempo é, provavelmente, mais importante do que o valor assumido, por ele, em um determinado ano. Uma tendência de queda nesse quociente ao longo de um período deve ser objeto de análise aprofundada (LEE et alii, 1980 P.148).

Quociente de Solvência

A solvência de uma empresa mede sua capacidade de saldar todas as suas Obrigąões através da "venda" de todo o seu Ativo, em um prazo suficientemente grande. Esse conceito, 
portanto, refere-se ao longo prazo, ou seja, é uma medida de solvência financeira se a empresa for vendida.

Solvência Geral $=\begin{gathered}\text { Ativo Total } \\ \text { Passivo Circulante }+ \text { Exigivel L-P }\end{gathered}$

Quocientes de Endividamento

Fornecem uma idéia da estrutura de capital da empresa. Os indicadores usados são:

Participąão do Capital de Terceiros: indica a participação das Obrigacões assumidas com terceiros no capital total da empresa.

Participacão do Passivo Circulante + Exigivel L-P

Capital de Terceiros =

Participacão da Divida de Curto Prazo: dá uma idéia da distribuicão das dividas da empresa no tempo, ou seja, mede a participacão das Obrigacões de Curto Prazo (Passivo Circulante) no total das Obrigacões.

Passivo Circulante
$\begin{gathered}\text { Participação da Divida } \\ \text { de Curto Prazo }\end{gathered}$
- Passivo Circulante + Exigivel L-P

\section{Alavanca Financeira ("Leverage")}

Esse indice refere-se à capacidade de endividamento da empresa, ou seja, sua habilidade em obter recursos de terceiros. A medida que o indice aumenta, torna-se mais dificil contrair 
novas dividas ou empréstimos por aumentar o risco de inadimplência. Teoricamente, a empresa procura a combinacão entre - capital próprio (Patrimônio Liquido) e o de terceiros (Obrigações) que minimize o custo médio do capital (NORONHA, 1987) .

Alavanca Financeira $=\frac{\text { Passivo Circulante }+ \text { Exigivel L-P }}{\text { Patrimônio Liquido }}$

Para a concessão de financiamentos, as instituicões financeiras americanas dão preferência às empresas rurais que possuam uma razão de no máximo 1:1, o que significa a mesma proporcão de capital próprio e de terceiros no Passivo Total da empresa (BARRY et alii, 1983).

3.1.2. Demonstracão do Resultado do Exercicio (DRE) ou Demonstracão de Lucros e Perdas

De acordo com os objetivos deste trabalho, o modelo de Demonstracão do Resultado do Exercicio proposto segue, até certo ponto, a forma já consagrada na literatura contábil brasileira, ou seja, as determinações da Lei das S.A. (ANGELICO, 1982; IUDICIBUS et alii, 1983; MARION, 1986).

Entretanto, a DRE proposta contém alteracões substanciais que procuram adaptar, ao modelo da Lei, os requisitos necessários à análise econômica dos negócios de uma empresa agropecuária. Assim, tais alteracões basearam-se principalmente nos modelos revistos no capitulo anterior e no modelo de Contabilidade Rural desenvolvido por MARION (1985a e 
1985b), o qual segue mais de perto os dispositivos legais.

A seguir são descritos os principais componentes da DRE proposta apresentada na Tabela 5.

Receita Operacional Bruta

Neste demonstrativo, tanto as receitas como as despesas estão classificadas em operacionais e não-operacionais, seguindo a divisão do Modelo da Lei. Seus componentes, entretanto, não são os mesmos, como se verá adiante.

Como se trata de uma empresa rural, seu objeto social não está definido precisamente em contratos ou estatutos, como no caso de empresas não-rurais. Nesse caso, ele pode ser caracterizado pela producão agropecuária (produtos agricolas e pecuários) e pelas prestações de servicos nas propriedades de terceiros.

A Receita Operacional Bruta foi subdividida em quatro grupos: Inventário Permanente, Inventário Periódico, Apropriąão Direta e Prestacões de Servicos.

As duas primeiras subdivisões dizem respeito à receita operacional bruta gerada por produtos agropecuarios com regimes permanente e periódico de controle de estoques. Nos dois casos, a Receita Operacional Bruta engloba tanto as Vendas de Produtos Agropecuários, à vista e à prazo, quanto a renda correspondente aos produtos não vendidos mas que foram consumidos internamente (Consumo Interno) ou utilizados para pagamento de parcerias, servicos, etc. (Pagamentos em Espécie) ou usados nas atividades 
Tabela 5. Modelo Proposto de Eemonstraçăo do kesultado do Exercicio da Eqpresa e das Atividades fipropecuárıas

ESPRESA RURAL:

PERIODO:_I_La - I-

DATA:_'_-

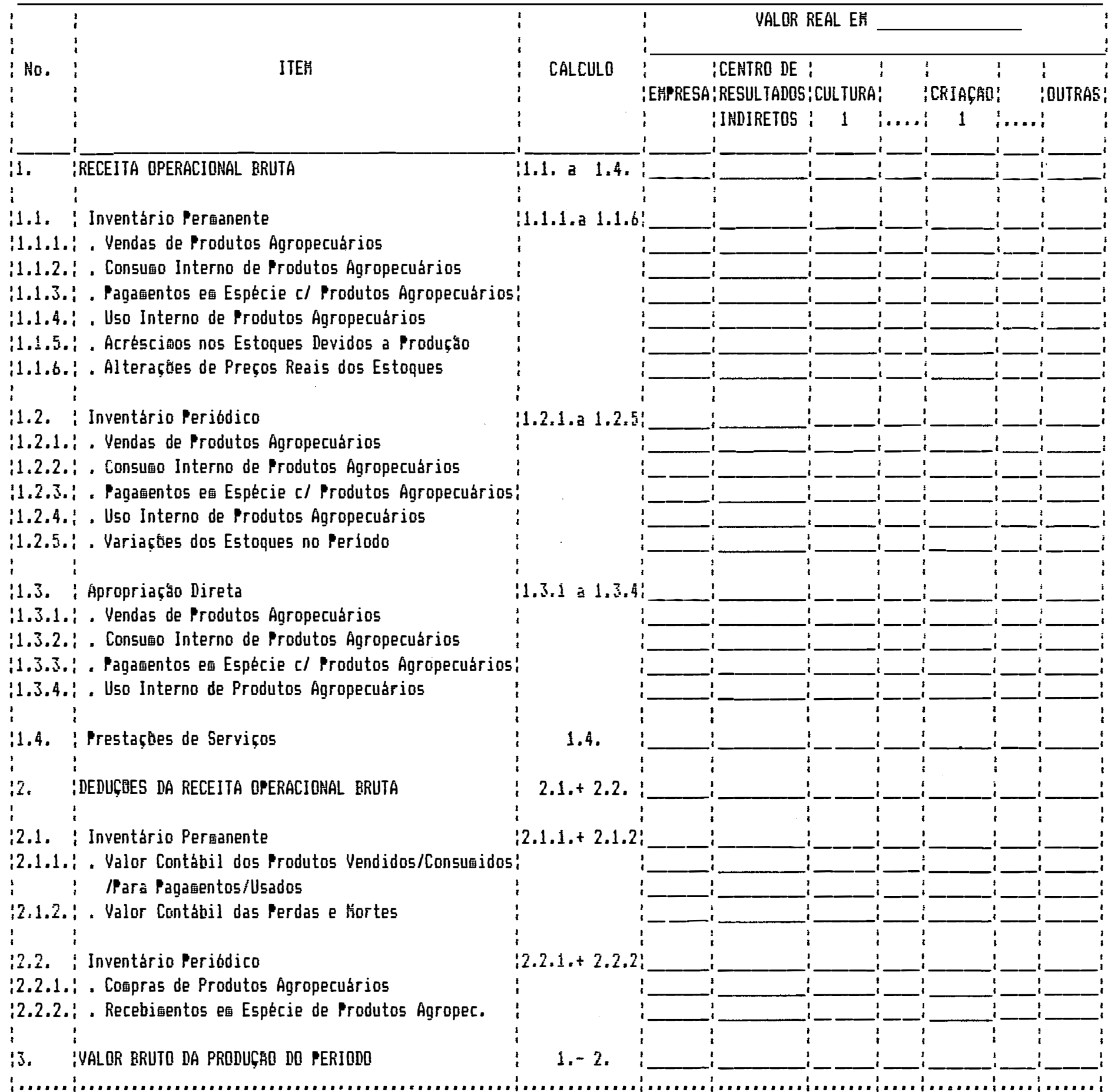

(continua) 
Tabela 5. (continuaçăo)

EHFRESA RUURAL:

PERIODO: _- ' -

DATA:_'_'-

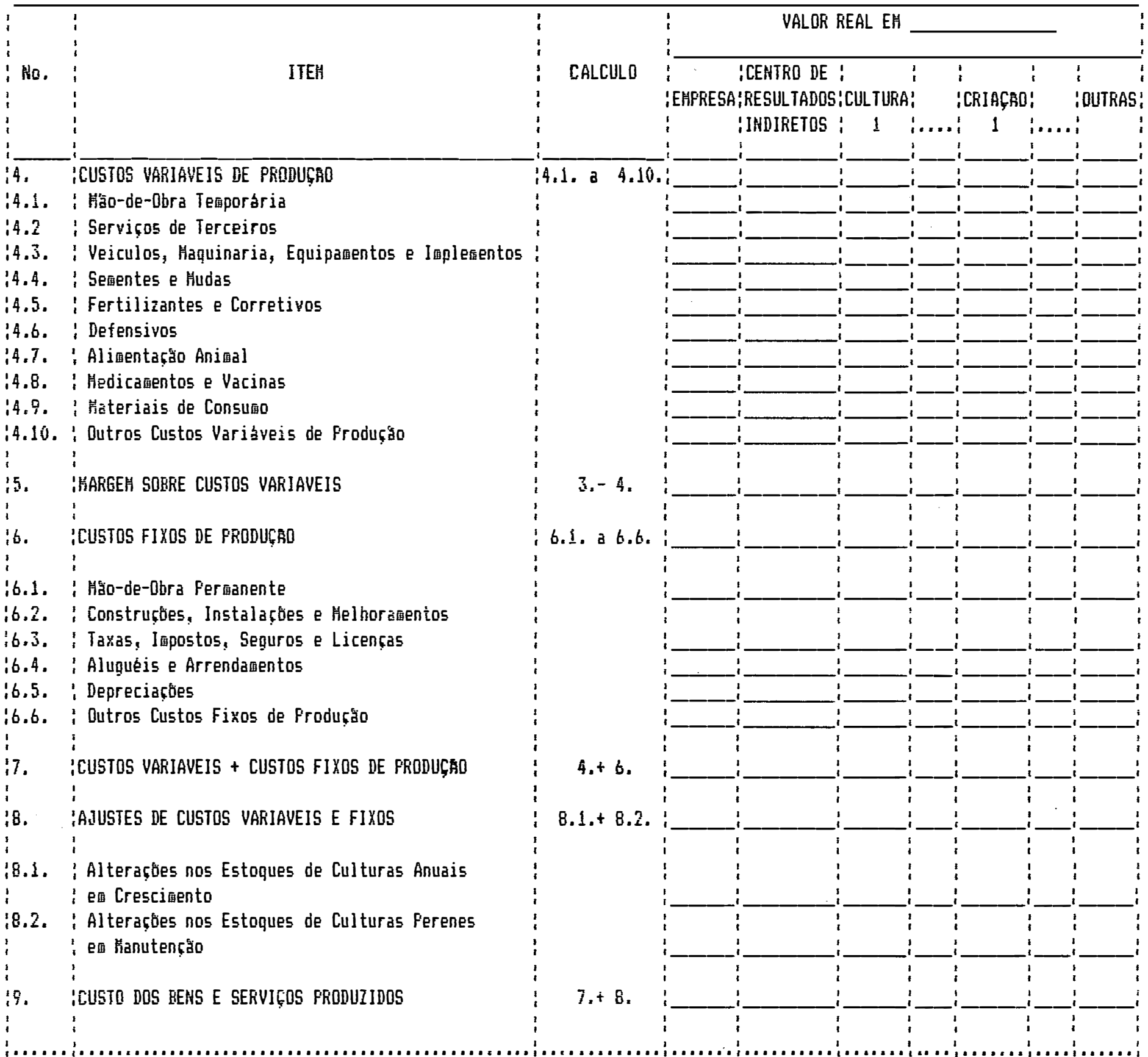

(continua) 
Tabe]a 5. (continuaçăo)

EHPRESA RURAL:

PERIODO: _L'_a L'-'-

DATA:_'I-

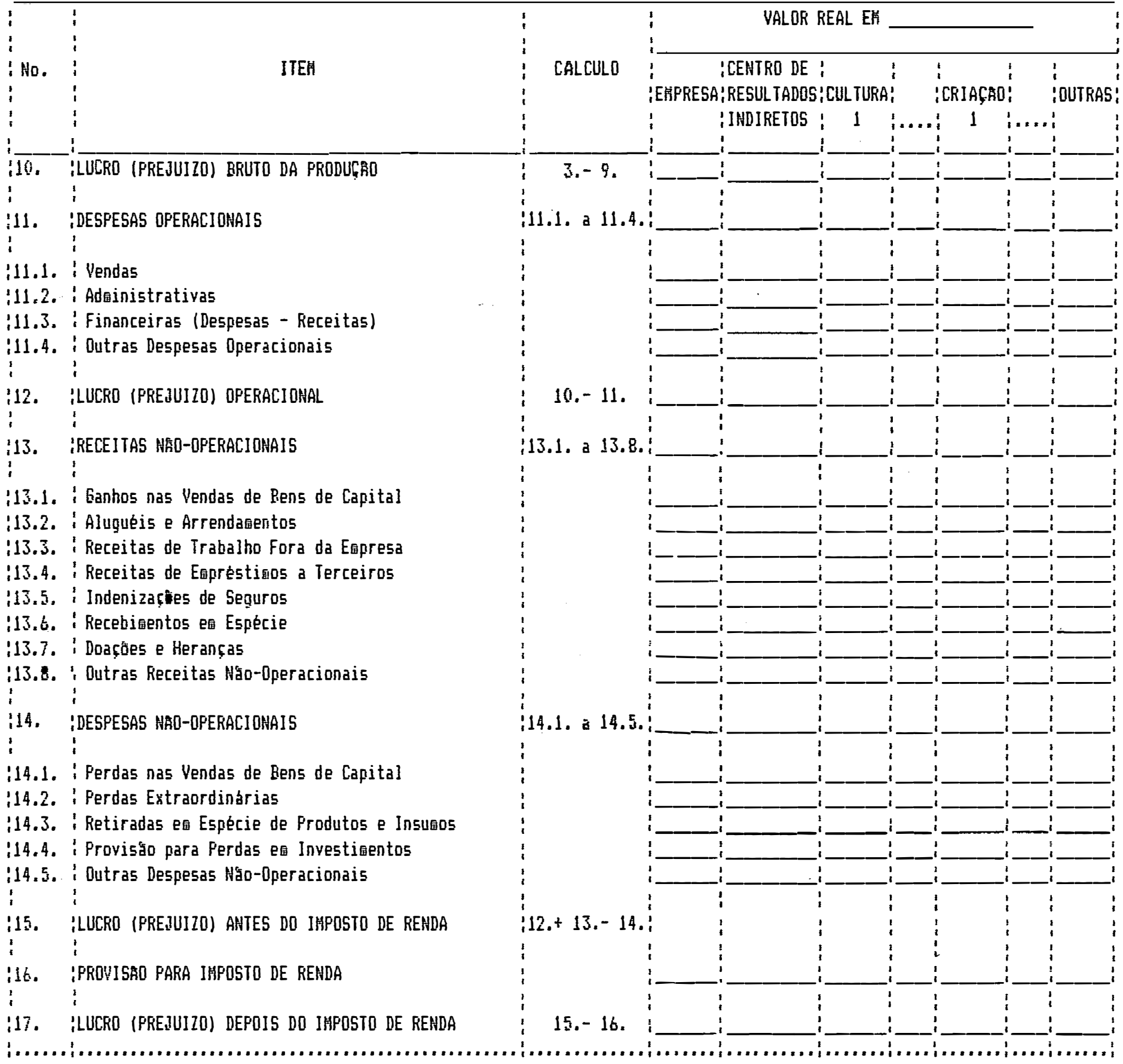

(continua) 
Tabela 5. (continuaçăo)

EFFRESA RURAL:

PERIODO: ' - _ a - - '

DATA: I' -

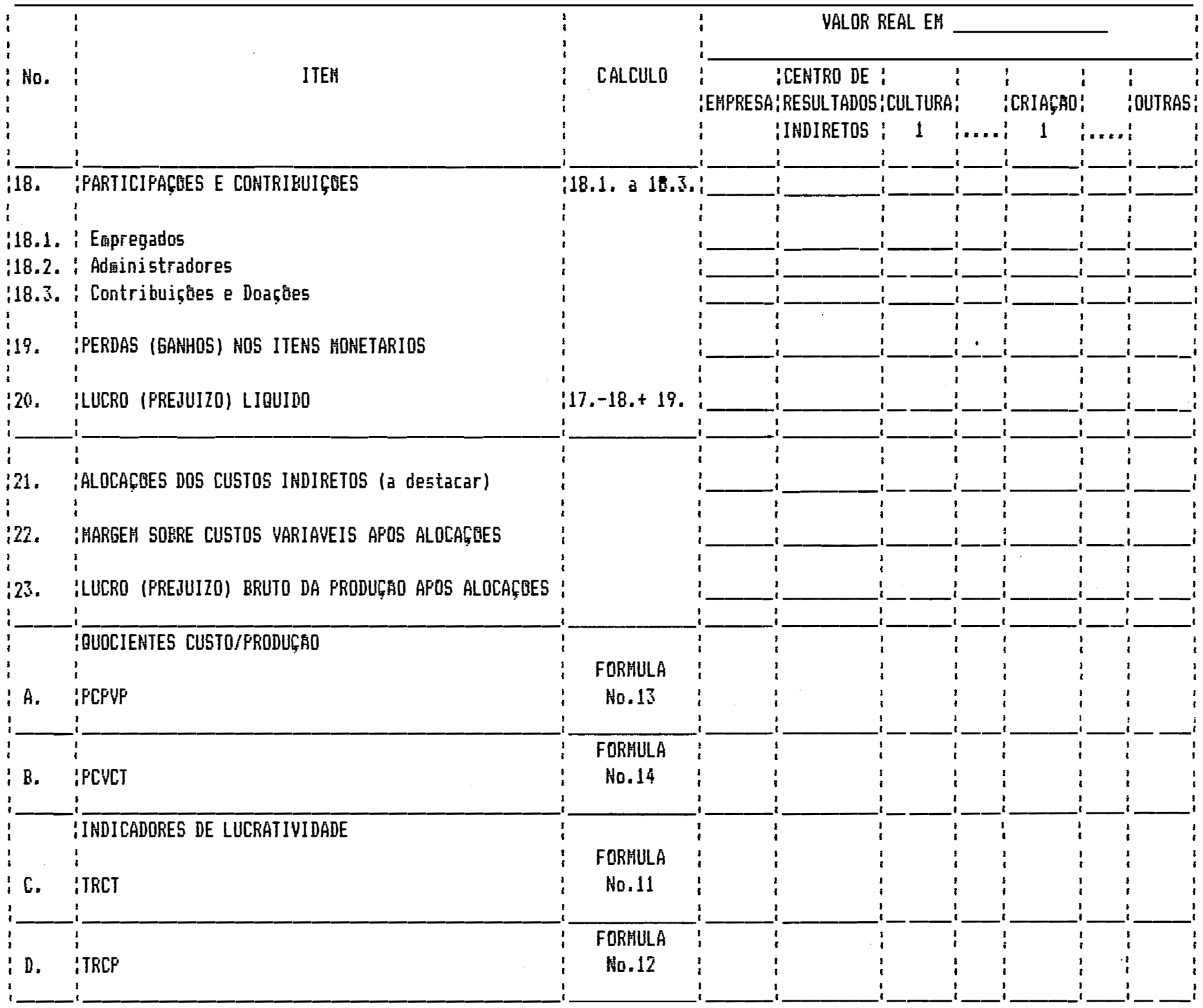


produtivas da própria empresa (Uso Interno).

Toda saida de produto do estoque será tratada como uma "venda", mesmo que não haja entrada de dinheiro no Caixa da empresa. Por exemplo, a retirada de milho do estoque para alimentar suinos é considerada uma venda da "atividade Milho" para a "atividade Suinocultura", ao preco prevalecente no mercado e que reflete o custo de oportunidade do milho no momento em que é utilizado.

Outro componente da Receita Bruta é a renda não-caixa gerada pela producão na forma de colheitas e nascimentos. No caso de Controle Permanente de Estoques, essa renda é lancada diretamente na conta Acréscimos nos Estoques Devidos à Producão. Além disso, com a avaliação dos estoques pelo preço de mercado é possível considerar o "ganho econômico" gerado pelo crescimento natural do gado e pela estocagem de produtos agricolas. Esse fato é ainda mais relevante com o caráter especulativo de certas atividades diante das flutuacões dos precos (por exemplo, a pecuária de corte). Assim, os aumentos e diminuicões dos precos relativos são incorporados como rendas ou despesas não-caixa na conta Alterações de Preços Reais dos Estoques.

Se o Inventário for Periódico, as alteracões nos estoques referentes à producão e flutuacões dos precos reais são apropriadas conjuntamente na conta Variações dos Estoques no Periodo (Valor do Estoque Final - Valor do Estoque Inicial).

Estas últimas transacões, que não envolvem movimento do Caixa, são muito frequentes nas empresas rurais e fazem com que o 
conceito de Receita Operacional Bruta deste Modelo seja substancialmente diferente daquele adotado pelo modelo da Lei que considera, como fonte de receita operacional da empresa, somente as vendas de produtos e servicos.

A terceira subdivisão refere-se à receita operacional gerada por bens que são produzidos e destinados imediatamente a alguma finalidade (Venda, Consumo Interno, Pagamentos em Espécie e Uso Interno) sem estocagem, o que é denominado Apropriação Direta.

Finalmente, para completar a Receita Operacional Bruta, é incluida a renda proveniente das Prestações de Servicos como aluguel de veiculos, maquinaria, equipamentos, implementos e animais de trabalho e servicos de mão-de-obra em outras propriedades. Nesse caso, a exemplo de FREY \& KLINEFELTER (1978, p.39), pressupõe-se que estas transações serão realizadas somente quando houver excedente de homens-dia, horas-máquina, etc., sendo os custos apropriados pela empresa prestadora do servico.

Deduções da Receita Operacional Bruta

Para os produtos com regime de Inventário Permanente, deve ser deduzido o valor que o produto vendido ou removido apresentava no estoque no momento de sua venda, retirada para consumo, pagamento em espécie ou uso interno (Valor Contábil do Produto Vendido / Consumido / Para Pagamento / Usado) e o Valor Contábil das Perdas e Mortes ocorridas durante o periodo. Dessa maneira, a empresa apropriará como receita operacional somente o diferencial entre o preco de mercado e o valor contábil do 
produto no momento da transação (venda, consumo, pagamento em espécie e uso interno), uma vez que a producão já foi registrada como receita em Acréscimos nos Estoques Devidos à Producão.

No caso de Controle Periódico de Estoques, devem ser subtraidas as entradas no estoque provenientes de fora da empresa, na forma de Compras e Recebimentos em Espécie de Produtos Agropecuários.

Valor Bruto da Producão do Período

Corresponde ao valor da renda agropecuária efetivamente produzida pela empresa rural no periodo considerado. Resulta da diferenca entre a Receita Operacional Bruta e as Deduçóes mencionadas anteriormente.

Esta é outra diferença marcante entre o demonstrativo proposto neste estudo e o da Lei. Neste último, toda a renda operacional provém de vendas realizadas no periodo contábil, enquanto neste Modelo, a renda é o valor da produção agropecuária do periodo, à semelhança dos modelos das instituições públicas estudadas.

Acredita-se que para a empresa rural, esta medida de renda seja, no momento, mais adequada por diversas razőes. Primeiro, o valor global da produção pode ser diretamente confrontado com seu custo, o que não ocorre no modelo da Lei onde o confronto é feito entre o que se vendeu no periodo contábil e o custo de produeão da parcela vendida. O Modelo proposto permite também conhecer os diversos componentes da renda agropecuária, 
ou seja, vendas, consumo, uso, etc..

Além disso, nas análises mais detalhadas do desempenho das diversas atividades agropecuárias da empresa, o valor da producão é utilizado no cálculo de indicadores de lucratividade.

Finalmente, acredita-se que sendo este conceito adotado pelas instituições públicas que assistem empresas na área de Administracão Rural, torna-se mais fácil a compreensão do Modelo proposto.

\section{Custos de Producão}

Correspondem ao valor dos recursos que, direta ou indiretamente, contribuiram para a geração do Valor Bruto da Produção do Periodo. Na DRE proposta está representado pelos Custos dos Bens e Servicos Produzidos, independentemente de ter havido ou não venda, consumo, pagamento em espécie ou mesmo uso interno.

Vale lembrar que, no modelo utilizado pelos profissionais de Contabilidade, o custo de producão apresentado na DRE corresponde somente ao custo das parcelas do produto e/ou serviço que foram vendidas no periodo. Isto é, os gastos de producão permanecem ativados no estoque, participando do Demonstrativo de Resultados sob a forma de Custo do Produto Vendido, somente quando houver o reconhecimento da receita trazida pela venda, como explicado anteriormente.

E importante notar que outros gastos incorridos pela empresa mas que não dizem respeito diretamente ao processo 
produtivo, não são levados em conta no cálculo desse item.

Neste Modelo, os custos de producão são apresentados em três grupos: Custos Variáveis, Fixos e Ajustes de Custos Variáveis e Fixos. Os custos variáveis são aqueles que variam com o volume de producão, tais como os itens de 4.1. a 4.10 da Tabela 5. Custos fixos, por outro lado, são gastos nos quais a empresa incorre independentemente de ter produzido ou não, estando representados pelos itens 6.1. a 6.6. da referida Tabela.

E importante salientar que os custos variáveis e fixos com insumos referem-se ao valor da parcela efetivamente usada na producão. Para apropriacão desses custos, o Modelo oferece três alternativas, embora o usuário deva optar por um dos sistemas, conforme o tipo de insumo. Assim, quando o insumo for comprado ou produzido e usado imediatamente, sem passar pelo estoque, caracteriza-se uma apropriacão direta e o custo corresponde ao valor da compra (valor de mercado do insumo).

Por outro lado, quando o insumo for comprado e colocado em estoque sob controle Permanente, seu custo é determinado pelo valor registrado na Ficha de Estoque no momento da retirada (Valor Contábil do Insumo Usado) e não pelo valor corrente de mercado. Esse procedimento contábil parte do pressuposto de que o objeto social da empresa rural não inclui atividades de especulação com insumos que não foram produzidos internamente. Ou seja, este Modelo considera que o produtor rural não visa lucros com estocagem de insumos comprados, reconhecendo apenas o "ganho econômico" gerado pela estocagem de produtos agropecuários, a 
exemplo de JAMES \& STONEBERG (1986).

No caso do insumo ser resultante da producão da empresa, o custo da sua utilizacão corresponde ao seu valor de mercado, refletindo o custo de oportunidade desse insumo, no momento em que é usado na producão.

Caso o inventário seja Periódico, o custo (uso) do insumo comprado, é apurado pelo cálculo: Estoque Inicial + Compras + Recebimentos em Espécie - Vendas - Consumo Interno Pagamentos em Espécie - Perdas - Estoque Final.

Se o insumo for produzido dentro da empresa e controlado periodicamente, é recomendável que o usuário registre permanentemente o seu uso, ficando a produção como incógnita no cálculo do inventário, como será explicado no item 3.1.6. (Controle de Estoques).

Margem sobre Custos Variáveis

Consiste na diferenca entre o Valor Bruto da Producão do Período e os Custos Variáveis de Producão. Logo, essa medida não corresponde à "Margem Bruta" utilizada na Contabilidade Rural norte-americana, nem à "Margem de Contribuição" da Contabilidade de Custos, já que nestas são deduzidas também as Despesas Operacionais Variáveis.

Assim, a Margem sobre Custos Variáveis mostra o que cada atividade efetivamente traz à empresa como resultado do confronto entre o valor da renda por ela gerada e os custos que lhe podem ser imputados sem muita arbitrariedade (MARTINS, 1987 ). 


\section{Ajustes de Custos Variáveis e Fixos}

Neste Modelo, os únicos estoques que não são avaliados a preco de mercado correspondem às Culturas Anuais em Crescimento e Culturas Perenes em Manutenção. Isso porque seria praticamente impossivel atribuir um valor de mercado a bens cuja producão está, ainda, em andamento. Assim, esses estoques são controlados periodicamente pelo valor de custo (Controle de Estoques - item 3.1.6.) e os gastos de producão, manutencão e colheita dessas culturas são registrados nas contas de custos do periodo.

Este Modelo propõe que a alteracão no valor do estoque (Estoque Inicial - Estoque Final) represente um ajuste para os custos, de forma que só sejam reconhecidos os gastos que efetivamente contribuiram para a geracão da producão do período, de acordo com o Regime de Competência (MARION, 1986 p.104).

Assim, enquanto não houver colheita, o ajuste será negativo (EF > EI) e os custos da cultura anual ou perene, no periodo em questão, são anulados.

Caso ocorra colheita, o ajuste poderá ser positivo (EF < EI) ou negativo ( $E F>E I$ ) sendo, então, somado ou subtraido dos custos do periodo.

Dessa forma poderá haver uma confrontacão ideal entre os custos de producão da cultura anual e manutenção da cultura perene, com a renda não-caixa gerada pela colheita do periodo. 
Custos dos Bens e Servicos Produzidos

Para a obtencão dos Custos dos Bens e Servicos Produzidos é preciso somar ao valor dos Custos Variáveis + Custos Fixos de Produção, os Ajustes de Custos Variáveis e Fixos (item 8 da Tabela 5).

Lucro (Prejuizo) Bruto da Producão

E resultante da diferenca entre o Valor Bruto da Producão do Periodo e os Custos dos Bens e Servicos Produzidos.

Vale lembrar que, no modelo da Lei, o Lucro Bruto é obtido pela diferenca entre o valor das Vendas e o Custo dos Produtos Vendidos no periodo.

Despesas Operacionais

Abrangem todas as despesas necessárias para vender os produtos e servicos, administrar a empresa e financiar suas operações. Ou seja, são gastos que contribuem para a manutencão da capacidade de obtenção de receitas e não são associados a este ou aquele produto ou serviço (MARION, 1986; MARTINS, 1987).

Além das retiradas em dinheiro feitas pelo(s) proprietário(s)(Despesas Administrativas), compreendem também depreciações de Ativo Imobilizado e amortizações de Ativo Diferido não incluidas nos Custos de Produção (Outras Despesas Operacionais).

$$
\text { Cabe ressaltar, ainda, que o item "Despesas }
$$

Operacionais Financeiras" corresponde às remuneraçós aos 
capitais de terceiros, incluindo os juros incorridos sobre obrigações (Fornecedores, Títulos a Pagar, Empréstimos a Pagar, Financiamentos, etc.), as despesas bancárias e impostos sobre operações financeiras. Embora não seja propriamente uma despesa, a correcão monetária de dividas deverá ser, também, apropriada nesse item.

Desse total devem ser deduzidas as Receitas Financeiras que abrangem os rendimentos de Aplicações Financeiras (Overnight, Caderneta de Poupança, Fundos de Renda Fixa, etc.) e os juros e correcão monetária sobre créditos operacionais (Títulos a Receber).

Assim, as "Despesas Liquidas Financeiras" poderão ser obtidas através do seguinte cálculo:\{[Valor Real da Correção Monetária sobre Obrigaçoes + Valor Real dos Juros sobre Obrigações - (+) Valor Real do Ganho (Perda) sobre Obrigações] [Valor Real da Correcão Monetária sobre Créditos + Valor Real dos Juros sobre Créditos $+(-)$ Valor Real do Ganho (Perda) sobre Créditos]\}. O resultado equivale à efetiva despesa com juros, incorrida no periodo em questão. A natureza das perdas e ganhos sobre itens monetários será explicada adiante.

Caso seja do interesse da empresa estimar o Lucro Liquido de cada atividade, poderá ser feita a alocação das Despesas Operacionais pelas diferentes explorações.

Lucro (Prejuizo) Operacional

Esta medida é obtida subtraindo-se do Lucro (Prejuizo) 
Bruto da Producão, as Despesas Operacionais conceituadas acima. Corresponde ao lucro resultante da atividade operacional da empresa. Embora não seja equivalente à medida "Net Farm Income" da literatura norte-americana, é a que mais dela se aproxima.

Receitas Não-Operacionais

Referem-se a ganhos não diretamente relacionados com a natureza dos negócios da empresa. Um exemplo típico é o ganho realizado com a venda de um bem de capital cujo "Valor Real de Venda" é superior ao "Valor Contábil Real na Data da Venda". (valor do bem já depreciado).

Neste Modelo, as receitas provenientes do aluguel de imóveis, arrendamento de terras e trabalho fora da empresa são consideradas atividades não-operacionais, já que não se enquadram dentro daquilo que a empresa visa produzir. Também se encaixam nessa classificação os recebimentos em espécie como forma de pagamento por produtos vendidos ou servicos prestados, as receitas (juros e correcão monetária) de empréstimos a terceiros, as doações recebidas pela empresa, etc..

\section{Despesas Não-Operacionais}

São os gastos não relacionados diretamente com a atividade operacional da empresa. Os mais comuns são os prejuizos com a venda de itens do Ativo Permanente cujo "Valor Real de Venda" é inferior ao "Valor Contábil Real na Data da Venda". Incluem também as retiradas em espécie para consumo interno, as perdas extraordinárias (involuntárias) com secas, 
geadas, tempestades, granizo, incêndios, as doações feitas pela empresa, etc..

Lucro (Prejuizo) Antes do Imposto de Renda (LAIR)

Esta medida é obtida somando-se ao Lucro (Prejuizo) Operacional, as Receitas Não-Operacionais e subraindo-se do resultado as Despesas Não-Operacionais.

Provisão para Imposto de Renda

Corresponde ao valor do tributo que a empresa deve pagar sobre o lucro gerado por suas operacões no "ano-base". Vale ressaltar que devido ao Regime de Competência, o Imposto de Renda é deduzido no exercicio em que foi gerado e não no que será pago (exercicio financeiro). Embora esteja diretamente relacionado com o objeto social da empresa, o Imposto de Renda "não pode ser incluido como uma despesa operacional porque é incidente sobre o lucro do exercicio, no qual já estão computadas tanto as despesas operacionais quanto as não-operacionais" (GOUVEIA, 1982 P. 163).

Lucro (Prejuizo) Depois do Imposto de Renda

E obtido subtraindo-se do LAIR, a Provisão para Imposto de Renda. E importante lembrar que o Imposto de Renda não incide diretamente sobre o lucro contábil da empresa (LAIR) e sim sobre este lucro ajustado de acordo com as exigências da legislacão tributária (Lucro Real ou Tributável). Entretanto, a apuracão do Lucro Real não faz parte dos objetivos desta pesquisa e deverá ser efetuada extracontabilmente para as finalidades fiscais. 
Participações e Contribuiç̃es

Referem-se às parcelas do Lucro Depois do Imposto de Renda que são destinadas ao pagamento de elementos favorecidos por decisões dos proprietários ou pelos estatutos da empresa (empregados, administradores e instituicões ou fundos de assistência e previdência).

Perdas (Ganhos) nos Itens Monetários

Itens monetários são aqueles cujos valores nominais normalmente não sofrem alteracão, correspondendo às Disponibilidades (Caixa, Bancos e Aplicações Financeiras), Créditos e Obrigações a Curto e Longo Prazos.

Diante de uma situação inflacionária, a manutencão de ativos monetários, sem aplicacão ou sujeitos à uma correção monetária imperfeita, acarreta perdas não-realizadas financeiramente, diminuindo a rentabilidade real da empresa.

Por outro lado, podem ocorrer ganhos com a queda no valor real das Obrigaç̃̃es, durante o periodo contábil, em consequência da não adocão de um indexador, pelos credores da empresa, ou da utilização de um método inadequado, para essa finalidade.

Tanto as perdas como os ganhos ocasionados pela inflação serão calculados mensalmente, de forma que o valor anual seja igual ao somatório dos valores mensais, como será explicado no item 3.2.10 (O Tratamento da Infląão pelo Sistema Contábil). 
Vale lembrar que este item deve excluir as perdas e ganhos nas obrigações e créditos operacionais, já incluidos em "Despesas Liquidas Financeiras".

Lucro (Prejuizo) Liquido

Esta medida de resultado é obtida subtraindo-se do Lucro (Prejuizo) Depois do Imposto de Renda, as Participacões e Contribuições e as Perdas nos Itens Monetários (somando-se no caso de ganhos). Representa o valor liquido que é adicionado (ou subtraido, no caso de Prejuizo) ao saldo anterior de Lucros Acumulados (Patrimônio Liquido), sendo então destinado pelo empresário a ser retido na empresa e/ou distribuido ao(s) dono(s) do capital (Participacão do(s) Proprietário(s)). O Lucro Liquido corresponde à Renda Liquida ou "Net Income" dos modelos norteamericanos.

E importante destacar que nessa medida estão implicitas as remunerações daqueles fatores de produç̃o que, normalmente, não recebem pagamento direto por sua utilização nas atividades da empresa. São eles: o capital próprio empatado, a mão-de-obra familiar e a administração da empresa, representando os verdadeiros credores do resultado econômico gerado no periodo.

Os retornos a esses fatores correspondem a custos fixos não-caixa e são, tradicionalmente, calculados através de método residual, onde se atribui taxas de remuneracão consideradas "normais" a dois dos fatores, obtendo-se o terceiro por diferenca do Lucro Liquido. Isto é, o saldo restante equivale ao retorno ao fator remanescente (JAMES \& STONEBERG, 1986). 
Esse método, entretanto, não será empregado neste Modelo jä que haveria grande arbitrariedade em imputar taxas de remuneração "normais" aos fatores, sem qualquer contribuicão adicional no sentido de melhorar as análises econômicofinanceiras que fundamentam as tomadas de decisões do empresário. De acordo com NORONHA (1987, p.51) "não há razão para que se gastem tempo e esforso tentando obter estas medidas de resultado".

Contudo, se houver interesse do usuário, essas medidas poderão ser calculadas, correspondendo aos custos de oportunidade daqueles fatores, ou seja, as remuneraçoses obtidas em seus melhores empregos alternativos. Assim:

- retorno ao capital próprio empatado = remuneracão obtida na aplicacão mais rentável do capital próprio, no Mercado Financeiro;

- retorno à mão-de-obra familiar = salários dos membros da familia, nos melhores empregos alternativos da região;

- retorno à administracão = salário do administrador, no melhor emprego alternativo fora da empresa.

3.1.3. Demonstração do Resultado por Atividade de Producão Individual (DRA)

Para atender às finalidades gerenciais do Modelo, a DRA proposta tem como ponto de orientaç̃o a "Contabilidade por Atividade" ("Enterprise Accounting") desenvolvida por JAMES \& 
STONEBERG (1980) e (1986) e ARMBRUSTER (1980).

Assim, cada "atividade" da empresa é tratada como um "Centro de Lucro", permitindo a análise da rentabilidade de cada uma, individualmente.

O Modelo propõe um Demonstrativo de Resultado para cada atividade produtiva, mesmo que seu produto final seja intermediário e utilizado como insumo de outras atividades da empresa. Nesse caso a produção é "vendida" (Receita = Uso Interno) para outra(s) atividade(s) ao preco prevalecente no mercado, como foi explicado anteriormente.

Para as atividades de criacão animal que abrangem mais de uma fase produtiva, como por exemplo a Pecuária de Corte (cria-recria-engorda), ocorre um "relacionamento de compra e venda" entre os diferentes estágios de formação dos animais. Assim sendo, os bezerros desmamados retidos devem ser "vendidos" para a atividade de recria, que por sua vez "vende" novilhas na idade de primeira cobertura para a fase de cria e bois magros para a fase de engorda. Tal procedimento tem a finalidade de permitir a análise econômica de cada fase separadamente.

0 mesmo tratamento deve ser dado às atividades "Pastagens", cujo produto final é o volumoso utilizado na alimentação animal. Assim sendo, as áreas de pastos devem ser "alugadas" às diferentes criações que delas se utilizam.

Os animais de trabalho produzidos dentro da empresa (cavalos de lida, burros, jumentos, etc.) fazem parte de 
atividades especificas de criacão animal $e$, porisso, são "alugados" pelas outras atividades onde são empregados.

E importante lembrar que se os animais de trabalho forem comprados, eles deverão ser incluidos como componentes das. categorias das criacões animais para as quais prestam servicos. Nesse caso, os custos de manutencão desses animais (alimentação, medicamentos, etc.) são incorporados pelos custos do rebanho que os utiliza e sua depreciacão poderá ser obtida, residualmente, pela cálculo: (Valor Real Inicial + Compras - Vendas - Valor Real Final).

A DRA, entretanto, mantém a mesma estrutura da DRE da empresa, com o objetivo de uniformizar tanto a elaboracão quanto a análise desses relatórios. Assim, cada item da coluna "Empresa" (Tabela 5) deverá ser igual ao "somatório" dos valores apresentados na mesma linha horizontal ou, então, poderá ser obtido pelos cálculos indicados na vertical.

Para elaboracão desse demonstrativo, as informacões são alocadas diretamente às atividades produtivas (Cultura 1, Cultura 2, etc., Criacão 1, Criacão 2, etc. e Outras) ou, então, apropriadas por um "Centro de Resultados Indiretos", quando o procedimento de alocacão não for viável.

A coluna "Outras" representa uma DRA que acumula informąõos de atividades menos representativas para a rentabilidade da empresa e que, porisso, não justificam uma análise individualizada. Já o "Centro de Resultados Indiretos" apropria todas as receitas, custos, despesas e outras formas de 
resultado que nåo podem ser diretamente associados à atividades especificas.

Assim, receitas de caráter geral, como as prestacões de serviços, são apresentadas no Centro de Resultados Indiretos pois estão mais comumente associadas à empresa como um todo.

Os custos de produção devem ser alocados às atividades quando for possivel efetuar uma medicão direta e objetiva durante - processo produtivo. São exemplos de Custos Diretos os gastos com sementes e mudas, fertilizantes e corretivos, defensivos, alimentacão animal, etc..

Certos custos não podem ser distribuidos pelas atividades produtivas no momento em que ocorrem e necessitam de bases de rateio ou estimativas para serem alocados. São os Custos Indiretos que abrangem quase todos os Custos Fixos e parte dos Variáveis. Também são tratados como Indiretos certos Custos Diretos de difícil medicão, como ocorre com o uso de veículos, maquinaria, equipamentos e implementos.

Os empreendimentos de criacão animal permitem a apropriação desses custos com maior facilidade porque, normalmente, contam com pessoal e maquinaria para seu uso exclusivo, o que não ocorre com a producão agrícola.

Assim, os custos que não forem diretamente apropriados devem ser apresentados na coluna "Centro de Resultados Indiretos" para posterior alocação (Alocacões dos Custos Indiretos), quando então podem ser calculadas novas medidas de resultado para cada 
atividade (Margem sobre Custos Variáveis Após Alocacões, Lucro Bruto da Producão Após Alocações).

Em determinadas situacões, apenas uma parcela dos custos pode ser distribuida imediatamente às atividades. Nesse caso, o valor a ser apresentado na DRE é igual à soma dos registros das DRAs com o montante contabilizado pelo Centro de Resultados Indiretos.

Apesar de não haver um método seguro para alocacão dos custos indiretos, alguns critérios são sugeridos na literatura (BRANNEN, 1977; JAMES \& STONEBERG, 1980 e 1986; MARTINS, 1987):

1) Apropriacão dos Custos Indiretos conforme contribuicão de cada empreendimento na formacão do Valor Bruto da Produção da empresa.

2) Apropriacão dos Custos Indiretos proporcionalmente ao que cada atividade já recebeu de Custos Diretos.

3) Apropriacão dos Custos Indiretos com base em percentuais estipulados pelo empresário, para cada atividade.

A combinacão desses métodos pode levar a resultados mais exatos năo sendo, porém, fácil de ser aplicada. Portanto, a escolha da alternativa mais viável fica a critério do usuário que levará em consideracão as necessidades da empresa. A consistência na aplicacão e a explicitacão dos critérios escolhidos é fundamental para que haja comparabilidade entre resultados de diferentes periodos, na mesma empresa e entre empresas distintas. 
E importante lembrar que a alocạ̣ão dos Custos Fixos tem pouca utilidade gerencial no curto prazo e pode levar a conclusões distorcidas já que os mesmos independem do volume de producão e podem, eventualmente, ser apropriados em funcão da quantidade produzida. Portanto, as decisões tomadas com base no Lucro Liquido podem não ser muito corretas (MARTINS, 1987).

De forma geral, é preferivel omitir alguns elementos menos significativos para a análise da atividade do que fazer suposicões que podem acarretar resultados distorcidos. Assim sendo, no curto prazo, a "Margem sobre Custos Variáveis" se apresenta como o indicador mais consistente da rentabilidade de cada explorạ̣ão agricola ou animal (MARTINS, 1987).

A partir do item "Despesas Operacionais" ate "Lucro (Prejuizo) Liquido" encontra-se um conjunto de receitas e despesas que não se relaciona diretamente com alguma atividade em particular, mas pertence à empresa total ou um grupo de atividades produtivas.

A alocacão desses itens contribui muito pouco na avaliação da lucratividade de cada exploração. Contudo, eventualmente pode ser interessante utilizar um determinado critério para apropriar algumas dessas receitas e despesas gerais pelas atividades, particularmente quando se considera politica agricola, contratos de arrendamento, etc.. Nesse caso, o "Lucro (Prejuizo) Liquido" é a medida usada para avaliar a rentabilidade da cultura ou criacão. 


\section{Indicadores Econômicos}

Com base nos dados fornecidos pelos Balan£os Patrimoniais e pela Demonstracão do Resultado do Exercicio podem ser calculados vários tipos de indicadores econômicos ou de rentabilidade. São quocientes que se referem a periodos enquanto os indicadores financeiros, mencionados anteriormente, dizem respeito a uma determinada situação numa determinada data (IUDICIBUS, 1982; MARION, 1986). Neste Modelo serão utilizados:

\section{Quocientes de Retorno ao Capital}

Taxa de Retorno ao Capital Total (TRCT): definida como a razão entre o Retorno Liquido ao Capital Total (RLCT) e o valor médio do Ativo Total de dois balancos consecutivos (A1 e A2).

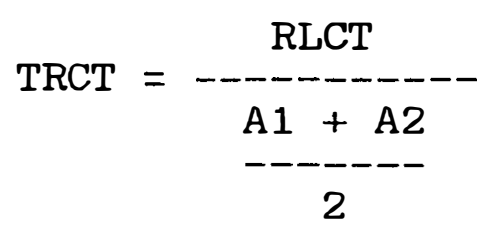

onde: $\quad$ RLCT $=$ Lucro Liquido + Juros Pagos a Terceiros - Retorno à Mão-de-Obra Familiar - Retorno à Administração.

Taxa de Retorno ao Capital Proprio (TRCP): definida como a razão entre o Retorno Liquido ao Capital Próprio (RLCP) e - valor médio do Patrimônio Liquido ou capital próprio de dois balanœos consecutivos (PL1 e PL2).

$$
\text { TRCP }=\frac{\text { RLCP }}{\frac{\text { PL1 } 1+\mathrm{PL} 2}{2}}
$$


onde: RLCP = Lucro Liquido - Retorno à Mão-de-Obra Familiar

- Retorno à Administracão.

\section{Quocientes Custo/Producão}

Participacão do Custo de Produção no Valor Bruto da Producão (PCPVP) - este indicador mede a participacão do custo total de producão no valor bruto da producão do bem ou servico. E importante frisar, mais uma vez, que o custo total de producão exclui gastos gerais da empresa, como por exemplo as despesas administrativas. Tal indicador pode ser assim obtido:

$$
\text { PCPVP = } \begin{gathered}
\text { Custo do Produto (Servico) Produzido } \\
\text { Valor Bruto da Producão }
\end{gathered}
$$

Participacão do Custo Variável sobre o Custo Total (PCVCT) - este indicador dá uma idéia da importância dos Custos Variáveis no Custo Total, que pode ser assim avaliada:

$$
\begin{gathered}
\text { Custos Variáveis }+ \text { Ajustes de } \\
\text { de Produção }
\end{gathered}
$$

3.1.4. Demonstracão do Fluxo de Caixa (FC) ou Demonstracão das Fontes e Usos de Recursos

A proposta de elaboracão do Fluxo de Caixa vem suprir uma lacuna existente na Contabilidade Rural brasileira que é a análise da disponibilidade de dinheiro pela empresa agropecuária. o Lucro Liquido apurado pela DRE é uma boa medida de rentabilidade, porém não está diretamente relacionado com o 
montante de dinheiro em Caixa e nos Bancos, devido ao Regime de Competência.

No Modelo proposto, a elaboração desse demonstrativo segue a estrutura normalmente adotada pela literatura contábil brasileira (MARION, 1986). Tem como ponto de partida as Entradas (Fontes) e Saidas (Usos) de dinheiro da empresa que são obtidas a partir da DRE incluindo, adicionalmente, as vendas e compras de bens de capital como imóveis, veículos, maquinaria, etc., assim como investimentos na forma de construcão de novas benfeitorias, instalações e melhoramentos. Mostra, também, os investimentos "caixa" no Capital da empresa e as participações do(s) proprietário(s) sobre o saldo de Lucros Acumulados. A Tabela 6 apresenta o Demonstrativo do Fluxo de Caixa em valores correntes.

$\mathrm{Na}$ parte inferior da Tabela 6, são apresentados dois resumos: "Transações de Caixa" e "Transacões de Crédito" da empresa, incorporados dos modelos norte-americanos (JAMES \& STONEBERG, 1980; LEE et alii, 1980). Eles especificam as amortizações das dividas $e$ as parcelas das novas dividas contraidas não apresentadas pela DRE que mostra apenas as despesas com os juros e a correção monetária dos empréstimos, financiamentos e outras dividas (Despesas Financeiras).

No resumo "Transaçós de Caixa"18/, o Caixa Final de cada mês (que é igual ao Caixa Inicial do mês seguinte) é assim calculado:

$18 / \mathrm{Na}$ realidade o termo "Caixa" refere-se ao ativo "Disponibilidades", que inclui também Bancos. 
Tabela 6. Hodelo Proposto de Fluxo de Caina

EMFRESA RULRAL:

PEFIODO: $\frac{1}{1} \frac{1}{1}-\frac{1}{1}+1-$
DATA:
VALOR CORRENTE

Ho. ITEH

\begin{tabular}{lllll}
\multicolumn{3}{c}{ HES } & & \\
1 & 2 & 3 & $\ldots$ & 12
\end{tabular}

1. EHTRADAS

1.1. Vendas de Produtos Agropecuários

1.2. Vendas de fiens de Capital

1.3. Frestaçóes de Serviços

1.4́. Receitas Financeiras (Juros e Correçăo Honetaria)

1.5. Aluqueis e Arrendacentos

1.6. Receitas de Trabalho Fora da Empresa

1.7. Receitas de Exprestiros a Terceiros

1.8. Indenizaçbes de Sequros

1.9. Vendas de Insuros e Materiais de Consuro

1.10. Investirentos Caira no Capital da Eqpresa

1.11. Outras Entradas

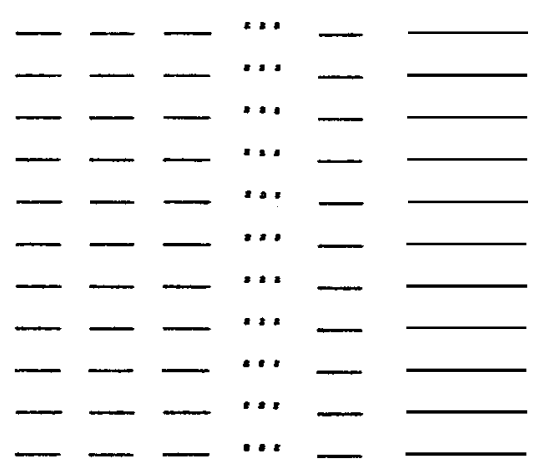

SUE-TOTAL

2. SAIDAS

2.1. Hán-de-Obra Teqporária, Fermanente

2.2. Serviços de Terceiros

2.3. Velculus, Haquinaria, Equip. e Irplementos (combust.,etc.)

2.4. Hateriais de Consugo

2.5. Alimentafóno Animal

2.6. Dutros Custos Cäixa con Criaçóes

2.7. Fertilizantes, Corretivos e Defensivos

2.8. Dutros Custos Caiga com Culturas

2.9. Compras de Produtos Agricolas e frodutos Animais

2.10. Compras de Animais eq Formaça e Feprodutores

2.11. Construçôes, Instal. e Helhoramentos (reformas e wanut.)

2.12. Tahas, Impostos, Sequros e Licenças

2.13. Aluqueis e Arrendacentos

2.14. Eespesas Operacionais Adrinistrativas

2.15. Despesas Operacionais Financeiras (Juros e Correçáo Honet.)

2.16. Construşa de Fenfeitorias, Instalaç̧es, etc.

2.17. Cocpras de Bens de Capital

2.18. Investimentos Fora da Erpresa

2.19. I iposto sobre a Renda

2.20. Dutras Saldas

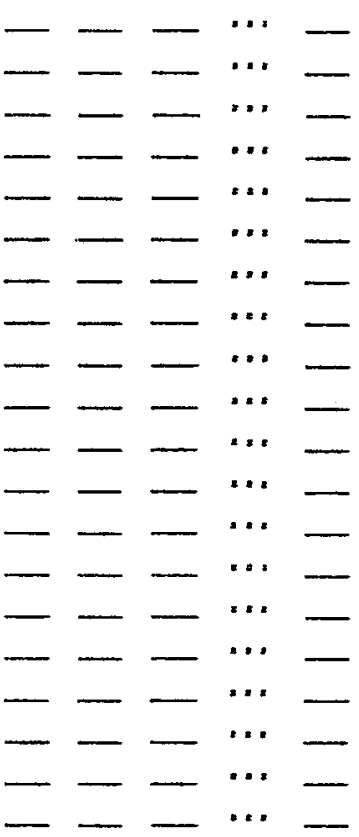

(continua) 
Tabela 6. Hodelo Froposto de Fluxo de Caixa (continuaģa)

EMPRESA FUURAL:

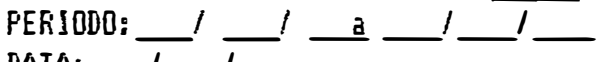

DATA:

VALOR CORRENTE

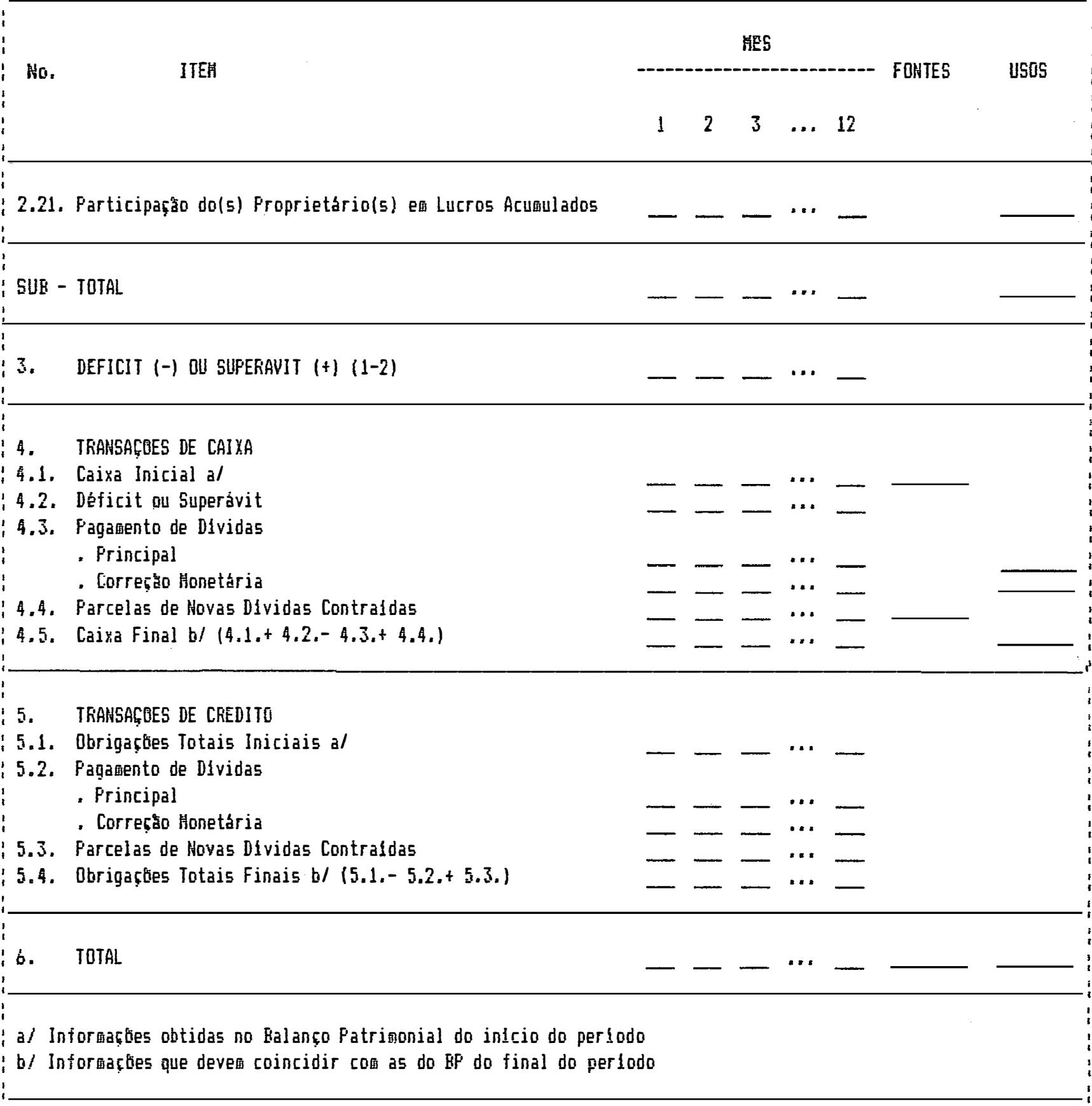




$$
C F(t)=C I(t)+(D / S)(t)-P P(t)-P C M(t)+P N D(t)
$$

onde:

$$
\begin{aligned}
\text { CF }(t) & =\text { Caixa Final do mês } t ; \\
\text { CI }(t) & =\text { Caixa Inicial do mês } t ; \\
(D / S)(t) & =\text { Déficit/Superávit do mês } t ; \\
\text { PP }(t) & =\text { Pagamentos de Principais do mês } t ; \\
\text { PCM }(t) & =\text { Pagamentos de Correcões Monetárias no mês } t ; \\
\text { PND }(t) & =\text { Parcelas de Novas Dividas Contraidas no mês } t .
\end{aligned}
$$

O resumo "Transações de Crédito", por sua vez, calcula - total das obrigacões no final de cada mês (que é igual ao total das obrigacões no inicio do mês seguinte), a partir de:

$$
\operatorname{OTF}(t)=\operatorname{OTI}(t)-\operatorname{PP}(t)-\operatorname{PCM}(t)+\operatorname{PND}(t)
$$

onde:

OTF (t) = Obrigacões Totais Finais do mês $t$;

OTI $(t)=$ Obrigacões Totais Iniciais do mês $t$;

PP (t) = Pagamentos de Principais do mês $t$;

PCM (t) = Pagamentos de Correcões Monetárias no mês t;

PND $(t)=$ Parcelas Novas Dividas Contraidas no mês $t$.

Finalmente, fechando o demonstrativo, apresenta-se a identidade entre os totais das Fontes e dos Usos dos recursos.

Embora o Demonstrativo do Fluxo de Caixa em valores correntes seja de grande importância para a empresa rural, sua versão em valores reais é que estará coordenada ao $B P$ e à DRE, como será explicado mais adiante.

Essa versão poderá ser obtida pela transformacão dos 
valores correntes de cada mês em valores reais, de acordo com o deflator utilizado pela empreza. Entretanto, tal procedimento requer a inclusão de dois itens adicionais referentes às perdas sobre o Ativo Monetário (Caixa, Bancos, Aplicações Financeiras e Créditos a Curto e Longo Prazos) e aos ganhos sobre o Passivo Monetário (Obrigạões), causados pela inflacão. Tais itens também farão parte da DRE da empresa, como foi mencionado anteriormente.

As perdas sobre as Disponibilidades e Créditos a Curto e Longo Prazos são assim calculadas:

$$
\operatorname{prc}(t)=\operatorname{cfr}(t)-[\operatorname{cfn}(t) / \operatorname{def}(t)]
$$

onde:

$$
\begin{aligned}
\operatorname{prc}(t)= & \text { perda no valor real das disponibilidades e } \\
& \text { créditos no mês } t ; \\
\text { cfr }(t)= & \text { valor real do saldo das disponibilidades e } \\
& \text { créditos no final do mês } t \text {, na contabilização } \\
& \text { em BTN ou US\$, etc.; } \\
\text { cfc }(t)= & \text { valor nominal das disponibilidades e créditos } \\
& \text { no final do mês } t \text {, na contabilização em Cr\$; } \\
\operatorname{def}(t)= & \text { valor do deflator no mês } t, \text { em cruzeiros } \\
& \text { correntes. }
\end{aligned}
$$

Por outro lado, os ganhos sobre as Obrigacões são calculados pela fórmula:

$$
\operatorname{gro}(t)=\operatorname{otfr}(t)-[\operatorname{otfn}(t) / \operatorname{def}(t)]
$$

onde:

$$
\begin{aligned}
\text { gro }(t)= & \text { ganho sobre as Obrigacões no mês } t ; \\
\text { otfr }(t)= & \text { valor real das Obrigacões Totais no final do } \\
& \text { mês } t, \text { na contabilizacão em BTN ou US\$, etc.; } \\
\text { otfn }(t)= & \text { valor nominal das Obrigacões Totais no final } \\
& \text { do mês } t, \text { na contabilizacão em Cr\$. }
\end{aligned}
$$


3.1.5. Coordenacão dos Demonstrativos Financeiros

- Balanco Patrimonial, a Demonstracão do Resultado do Exercicio e o Fluxo de Caixa originam-se do mesmo conjunto básico de dados, mas fornecem informacões que abrangem diferentes dimensões da empresa rural. Entretanto, esses relatórios podem ser coordenados com a finalidade de dar ao analista uma idéia mais completa da evolucão financeira da empresa através do tempo (LEE et alii, 1980).

A coordenacão entre os três demonstrativos pode ser compreendida através da Figura 4, cujo objetivo é ilustrar como o valor do Patrimônio Liquido do final do periodo pode ser obtido a partir do Patrimônio Liquido inicial.

Assim, fica claro que parte da alteracão no valor do Patrimônio Liquido deve-se ao valor do Lucro (ou Prejuizo) Líquido gerado no periodo compreendido entre os dois Balancos Patrimoniais. Além disso, são também responsáveis por essa variacão outros fatores que não fazem parte da DRE mas são apresentados nos outros demonstrativos (Balanco Patrimonial e Fluxo de Caixa). São eles: a variacão (aumento ou diminuicão) no valor real de itens do Ativo Permanente (Reavaliacão), o valor da participacão do(s) proprietário(s) sobre o saldo de Lucros Acumulados e seus investimentos no capital da empresa.

E importante notar que a mudanca causada pelo Lucro Liquido pode ainda se desdobrar em variacões na quantidade produzida e nos presos reais, uma vez que, no Modelo proposto, os produtos são avaliados a preços de mercado. 
Balanєo Patrimonial Inicial (BP1)

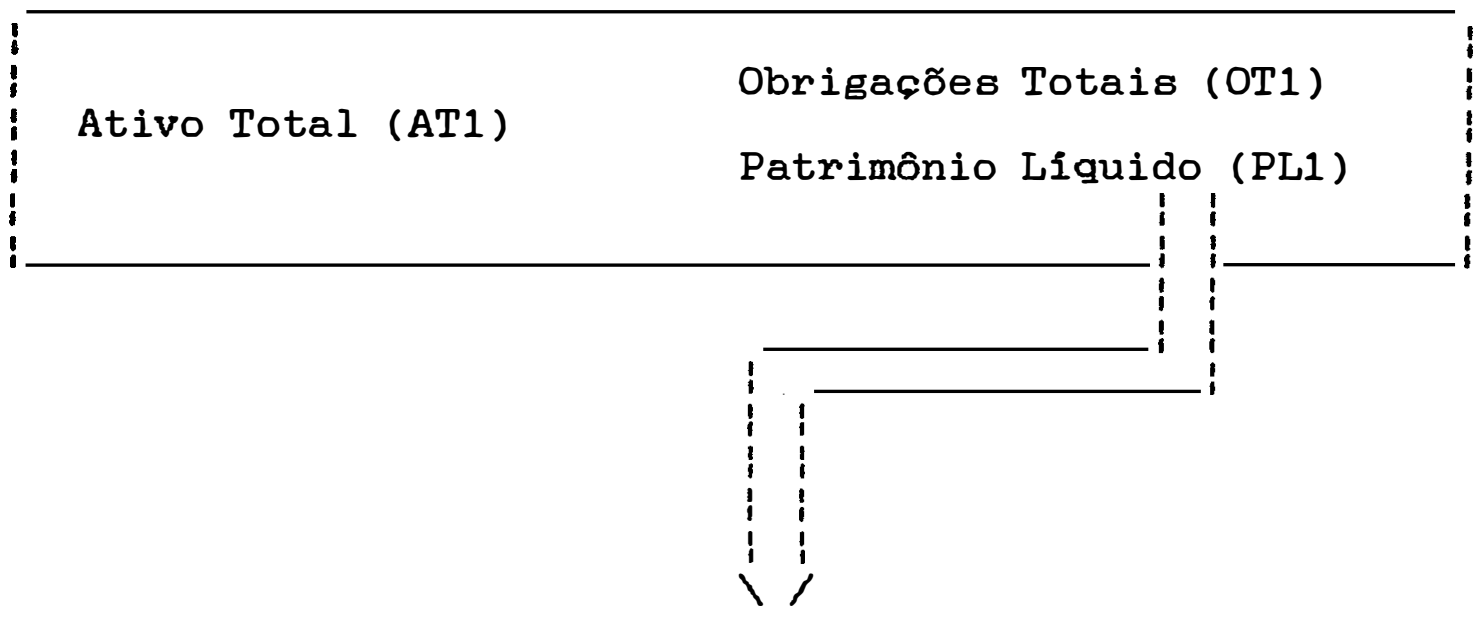

$(+/-)$ Lucro ou Prejuizo Liquido do Periodo (DRE)

$(+/-)$ Variação no Valor Real de Ativo Permanente (BP)

(-) Participąão do(s) Proprietário(s) em Lucros Acumulados(FC)

(+) Investimentos do(s) Proprietário(s) no Capital (FC)

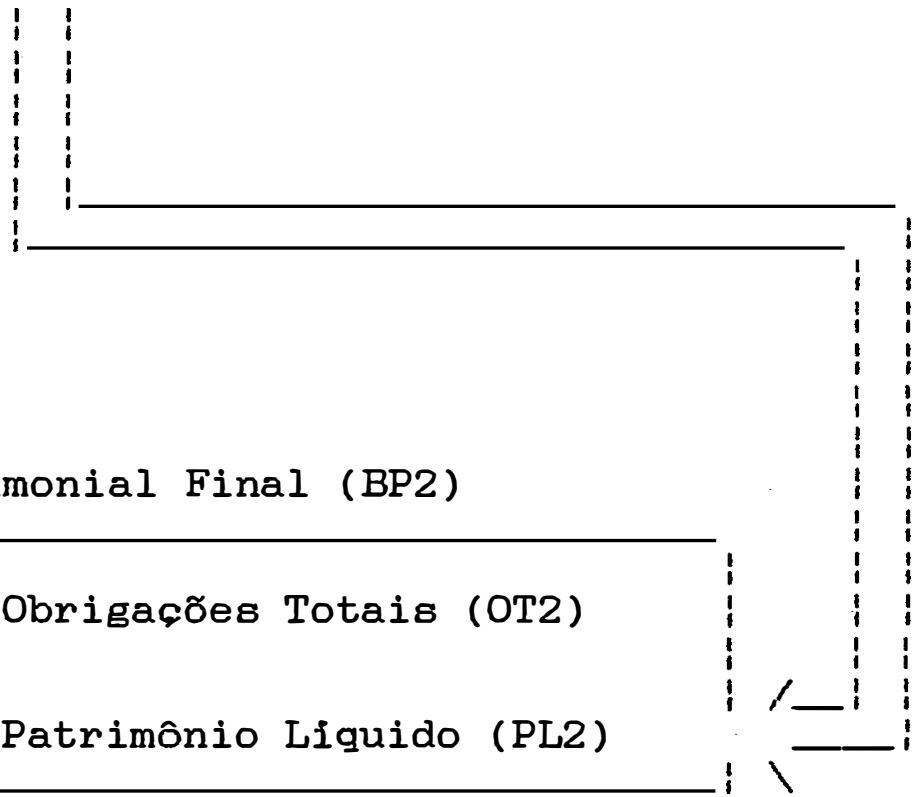

Balanco Patrimonial Final (BP2)

Ativo Total (AT2)

Obrigações Totais (OT2)

Patrimônio Liquido (PL2)

Figura 4. Coordenąão dos demonstrativos: Balanço Patrimonial, Demonstracão do Resultado do Exercicio e Fluxo de Caixa. 
Esse tipo de utilizacão coordenada dos demonstrativos não está presente nos sistemas brasileiros de Contabilidade Rural. Portanto, para ampliar a capacidade informativa deste Modelo, o BP, a DRE e o FC têm as suas informacões integradas permitindo uma maior compreensão sobre as razões do progresso (ou retrocesso) financeiro e auxiliando os futuros planejamentos da empresa.

\subsubsection{Informativos Auxiliares}

Com a finalidade de complementar as informações obtidas nos demonstrativos apresentados, serão elaborados informativos auxiliares na forma de Controles ou Relatórios Extracontábeis.

Este Modelo dará ênfase ao desenvolvimento do Controle de Estoques e do Controle de Ativo Imobilizado. Os demais controles poderão ser obtidos a partir dos Razões Auxiliares, como será visto adiante, no item 3.2.9..

Controle de Estoques

Além do Balanço Patrimonial, que é um inventário geral das existências da empresa ocorrem, em sentido restrito, inventários mais especificos que se referem à identificacão dos bens em estoque. Existem, basicamente, dois sistemas: Inventário ou Controle de Estoques Periódico e Inventário ou Controle de Estoques Permanente (GOUVEIA, 1982; IUDICIBUS et alii, 1983; LEITE, 1988; MARION, 1986).

O Modelo proposto é flexivel quanto ao tipo de controle 
de estoques a ser adotado, ou seja, o usuário poderá optar pelo Inventário Permanente ou pelo Periódico, conforme as caracteristicas do produto ou insumo que é estocado.

E importante lembrar que determinados itens são produzidos (ou adquiridos) e destinados à venda, consumo interno, uso, etc. sem, contudo, passarem pelo estoque. Como foi dito anteriormente, esse procedimento é denominado Apropriação Direta e ocorre, principalmente, com produtos agrícolas não estocáveis (olericolas, frutas e outros produtos pereciveis) e com insumos e materiais de consumo comprados para serem imediatamente utilizados.

Inventário Periódico

E levantado apenas no final de cada periodo contábil e recomendado para aqueles bens estocados, cujo valor é considerado secundário dentro do Estoque Total da empresa dispensando, portanto, um controle mais rigoroso. Tais como:

- Produtos Agrícolas Menos Representativos no Valor Bruto da Produção da empresa e

- Insumos e Materiais de Consumo Comprados.

Vale lembrar que o método usado para avaliar o grau de representatividade dos bens no Estoque, fica a critério do usuário.

Este tipo de inventário também é recomendado para bens cujo controle permanente é de dificil execucão ou perde a sua 
praticidade, como ocorre com os estoques de:

- Culturas Anuais em Crescimento;

- Culturas Perenes em Manutencão e

- Animais em Formacão.

A adocão do Controle Periódico para estoques de insumos produzidos pela empresa requer o registro permanente do uso desse bem nas atividades produtivas onde for empregado, para que o valor da producão do insumo possa ser calculado conforme a equacão (21) abaixo. O Modelo proposto adota tal procedimento porque considera cada uma das atividades produtivas da empresa como um "Centro de Lucro", de forma que seja possivel conhecer a rentabilidade de todas elas, separadamente.

A contabilização do Inventário Periódico obedece às seguintes etapas:

1. Inicio do Periodo - apuração do Estoque Inicial que equivale ao Estoque Final do periodo anterior.

2. Final do Periodo - levantamento de um Inventário Fisico dos bens em estoque e atribuicão de um preço de custo ou de mercado a cada item inventariado, de forma que:

$$
E F=Q f X P
$$

onde:

$$
\begin{aligned}
\mathrm{EF}= & \text { Estoque Final } \\
\mathrm{Qf}= & \text { Quantidade Total no Final do Periodo e } \\
\mathrm{P}= & \text { Pręo de Custo ou de Mercado (conforme será } \\
& \text { explicado adiante). }
\end{aligned}
$$


3. Final do Periodo- cálculo indireto das seguintes infiormacões apresentadas nos Demonstrativos de Resultados do Exercicio (DRE e DRAs), com respeito a:

a) Culturas Anuais em Crescimento

$$
\mathrm{CPCA}=\mathrm{EI}+\mathrm{CCAP}-\mathrm{EF}
$$

onde:

$$
\begin{aligned}
& \text { CPCA = Custo de Producão da Cultura Anual; } \\
& \text { CCAP = Custo da Cultura Anual no Periodo }
\end{aligned}
$$

ou

$$
\mathrm{CPCA}=\mathrm{CCAP}+\mathrm{AECA}
$$

onde:

$$
A E C A=E I-E F
$$

ou seja:

AECA = Alterạ̄a no Estoque da Cultura Anual, que corresponde ao Ajuste de Custos (item 8.1. da DRE).

b) Culturas Perenes em Manutengão (exceto Pastagens)

$$
\mathrm{CMCP}=\mathrm{EI}+\mathrm{CCPP}-\mathrm{EF}
$$

onde:

$$
\begin{aligned}
& \text { CMCP = Custo de Manutencão da Cultura Perene; } \\
& \text { CCPP = Custo da Cultura Perene no Período }
\end{aligned}
$$

ou

$$
\mathrm{CMCP}=\mathrm{CCPP}+\mathrm{AECP}
$$

onde:

$$
\mathrm{AECP}=\mathrm{EI}-\mathrm{EF}
$$

ou seja:

AECP = Alterąão no Estoque da Cultura Perєne, que 
corresponde ao Ajuste de Custos (item 8.2. da DRE).

c) Produtos Agricolas Menos Representativos

$$
\mathrm{VBP}=\mathrm{V}+\mathrm{CI}+\mathrm{PE}+\mathrm{U}+(\mathrm{EF}-\mathrm{EI}-\mathrm{C}-\mathrm{RE})
$$

onde:

$$
\begin{aligned}
& \text { VBP }=\text { Valor Bruto da Producão do Periodo; } \\
& \mathrm{V}=\text { Valor das Vendas; } \\
& \mathrm{CI}=\text { Valor do Consumo Interno; } \\
& \mathrm{PE}=\text { Valor dos Pagamentos em Espécie; } \\
& \mathrm{U}=\text { Valor do Uso Interno do Produto; } \\
& \mathrm{C}=\text { Valor das Compras e } \\
& \mathrm{RE}=\text { Valor dos Recebimentos em Espécie }
\end{aligned}
$$

ou

$$
\mathrm{VBP}=\mathrm{V}+\mathrm{CI}+\mathrm{PE}+\mathrm{U}+\mathrm{AP}
$$

onde:

$$
A P=E F-E I-C-R E
$$

ou seja:

$$
\mathrm{AP}=\text { Alterąão no Estoque Devida à Produção. }
$$

d) Animais em Formacão

$$
\mathrm{VBP}=\mathrm{V}+\mathrm{CI}+\mathrm{PE}+\mathrm{U}+(\mathrm{EF}-\mathrm{EI}-\mathrm{C}-\mathrm{RE})
$$

ou

$$
\mathrm{VBP}=\mathrm{V}+\mathrm{CI}+\mathrm{PE}+\mathrm{U}+\mathrm{AP}
$$

e) Insumos e Materiais de Consumo

$$
\mathrm{UI}=\mathrm{EI}+\mathrm{C}+\mathrm{RE}-\mathrm{V}-\mathrm{PE}-\mathrm{P}-\mathrm{EF}
$$

onde:

$$
\text { UI = Uso Interno do Insumo ou Material de Consumo e }
$$




$$
P=\text { Valor das Perdas. }
$$

Para se evitar a necessidade de contabilizar as perdas e mortes individualmente, estas poderão ser incorporadas na Alteracão do Estoque, pela sua dedução do Estoque Final. Consequentemente, o empresário deverá estar alerta a uma possivel superestimativa do Valor Bruto da Producão e do Uso do Insumo ou Material de Consumo no periodo. Assim sendo:

$$
\mathrm{UI}=\mathrm{C}+\mathrm{RE}-\mathrm{V}-\mathrm{PE}+\mathrm{AE}
$$

onde:

$$
A E=E I-E F
$$

As consequências da adọ̣ão de um Regime de Controle de Estoques Periódico são:

a) O valor e a quantidade fisica dos estoques são conhecidos somente no final de cada periodo, isto é, não são permanentemente atualizados.

b) A conta de estoque permanece intacta durante o periodo. Após a primeira transacão, o seu saldo não mais representa o valor do estoque.

c) Durante o periodo são movimentadas apenas as contas que representam as entradas e saidas de estoque (Receitas e Despesas Caixa e Não-Caixa).

d) Recomenda-se os seguintes critérios de atribuição de preços ao inventário físico para avaliação do Estoque no final do período:

- Preso Corrente de Mercado - para Produtos Agrícolas Menos 
Representativos, Insumos e Materiais de Consumo e Animais em Formacão.

- Custo de Producão ou de Manutencão - para Culturas Anuais em Crescimento e Culturas Perenes em Manutenção (exceto Pastagens). Nesses dois casos, o valor do Estoque Final corresponde ao total dos custos incorridos a partir da última colheita até a data de levantamento do Balanco.

No caso das pastagens, é praticamente impossivel identificar os custos que efetivamente contribuiram para gerar a producão do periodo, já que não há um momento definido de colheita. Ou seja, o volumoso é consumido pelo gado durante quase todo o periodo de manutenção do pasto, o que não permite "diferenciar" os gastos referentes a essa producão, daqueles que dizem respeito ao periodo seguinte.

Assim sendo, sugere-se que todos os custos para manutenção das pastagens no periodo sejam confrontados, sem ajustes, com a renda equivalente ao seu Uso Interno pelas atividades animais, o que corresponde ao "aluguel" do pasto às diversas criações que dele se utilizam.

e) O Custo de Producão da Cultura Anual, o Custo de Manutenção da Cultura Perene, o Valor Bruto da Produção de Animais e Produtos Agricolas Menos Representativos e o Uso do Insumo ou Material de Consumo são informações apuradas, indiretamente, apenas no final de cada periodo contábil. 
Inventário Permanente

Caracteriza-se por um controle continuo de forma que, a qualquer momento, é possivel conhecer com certeza o valor e a quantidade fisica do estoque.

Este sistema é recomendado para bens de valor econômico mais representativo no Estoque Total da empresa, conforme - critério adotado pelo usuário, e que viabilizem a operacionalização do Inventário Permanente justificando, assim, um controle mais rigoroso do estoque. Nesse caso,

- Produtos Agrícolas que podem, eventualmente, ser utilizados na alimentação animal, tais como: milho-grão, milho-silagem, feno, sorgo, etc..

- Insumos Comprados com grande participacão nos custos de producão, tais como: concentrados para gado de leite, fertilizantes, óleo diesel para veiculos e maquinaria, etc..

Entretanto, se houver venda desses insumos para terceiros, recomenda-se que o usuário adote o Inventário Periódico, para evitar a necessidade de contas e lancamentos adicionais (Deduções de Receitas Não-Operacionais).

A realização do Inventário Permanente deverá ser feita mediante o preenchimento diário da Ficha de Estoque ilustrada na Tabela 7, onde as Entradas no estoque são representadas por:

- Estoque Inicial- referente ao valor do estoque do produto agricola ou insumo comprado, na primeira data registrada que 
iIteA EM ESTOQUE :

CODIGO DA CONTA DE ESTOQUE:

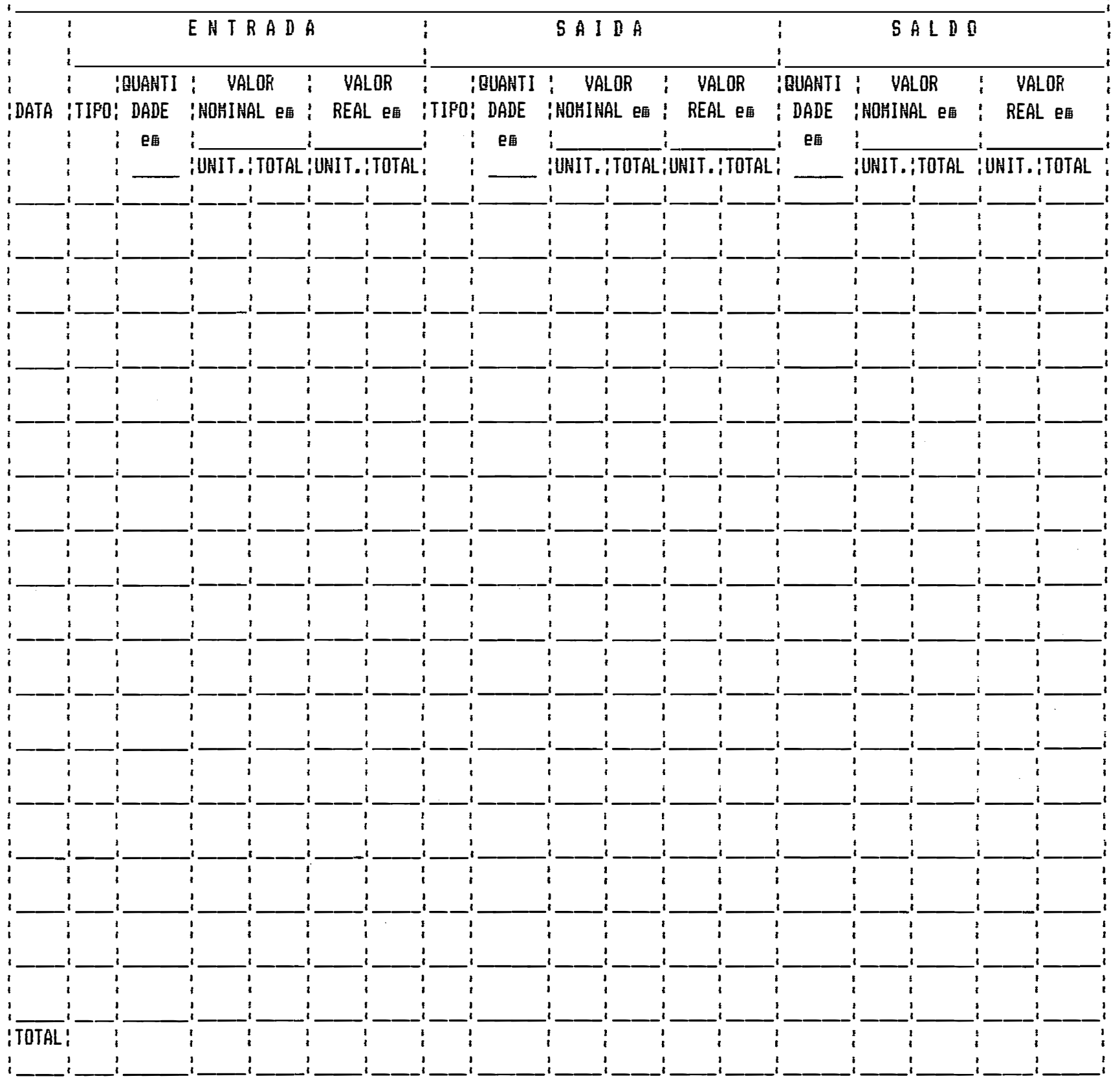


marca o inicio do periodo. Equivale ao valor do Estoque Final (Saldo) do periodo anterior.

Produção- referente ao valor da colheita do período que dá entrada no estoque do produto agricola acabado, em uma determinada data. Representa uma Renda Operacional Não-Caixa (Acréscimos nos Estoques Devidos à Producão), pois acarreta uma variação no Patrimônio Liquido sem realização financeira.

- Compras- referente à aquisicão do produto agricola ou insumo, à vista ou à prazo, em uma determinada data.

- Recebimento em Espécie- referente ao produto agricola ou insumo recebido em doacão no periodo, como pagamento de parceria, de produtos vendidos ou de servicos prestados. Representa uma Renda Não-Operacional Não-Caixa.

- Alteraç̃o de Preço Real ou Nominal-referente às variações (aumento ou diminuicão) dos preços reais dos produtos estocados. No caso de insumos comprados, serão registradas nessa conta apenas as alterações nos precos nominais, uma vez que este Modelo considera que a empresa rural não visa ganhos operacionais com a estocagem desses insumos.

As Saidas do estoque são representadas por:

- Vendas- referente ao valor que o produto agricola ou insumo apresentava no estoque na data em que foi vendido, ou seja, o Valor Contábil do Produto (ou Insumo) Vendido.

- Consumo Interno- referente ao valor que o produto agricola 
apresentava no estoque, na data em que foi retirado para consumo da familia ou empregados, ou seja, o Valor Contábil do Produto Consumido.

- Pagamento em Espécie- referente ao valor que o produto agricola ou insumo apresentava no estoque, na data em que foi retirado para o pagamento de parceria, de produtos comprados ou servicos prestados por terceiros, ou seja, o Valor Contábil do Produto (ou Insumo) para Pagamento.

- Uso- referente ao valor que o produto agricola ou insumo apresentava no estoque, na data em que foi retirado para ser usado na alimentação animal, na operação de veiculos, maquinaria, etc., ou seja, o Valor Contábil do Produto (ou Insumo) Usado.

- Perda- referente ao valor que o produto agrícola ou insumo apresentava no estoque, na data em que foi constatada a sua perda, ou seja, o Valor Contábil do Produto (ou Insumo) Perdido.

O Saldo representa o valor do Estoque do Produto Agricola ou Insumo, depois de cada operação de entrada ou saida.

No final do periodo são geradas as seguintes informacões apresentadas nos Demonstrativos de Resultados (DRE e DRAs), com respeito a:

a) Produtos Agricolas

$$
\begin{aligned}
\mathrm{VBP}= & \mathrm{V}+\mathrm{CI}+\mathrm{PE}+\mathrm{U}+\mathrm{PR}+\mathrm{AR}-(\mathrm{VCPV}-\mathrm{VCPC}-\mathrm{VCPP}- \\
& -\mathrm{VCPU}-\mathrm{VCPP})
\end{aligned}
$$

onde: 


$$
\begin{aligned}
\mathrm{U}= & \text { Uso Interno do Produto Agricola na Producão; } \\
\mathrm{PR}= & \text { Acréscimo no Estoque do Produto Agricola } \\
& \text { Devido à Producão; } \\
\mathrm{AR}= & \text { Alteração de Preco Real do Estoque; } \\
\mathrm{VCPV}= & \text { Valor Contábil do Produto Vendido; } \\
\mathrm{VCPC}= & \text { Valor Contábil do Produto Consumido; } \\
\mathrm{VCPP}= & \text { Valor Contábil do Produto para Pagamento; } \\
\mathrm{VCPU}= & \text { Valor Contábil do Produto Usado e } \\
\mathrm{VCPPe}= & \text { Valor Contábil do Produto Perdido. }
\end{aligned}
$$

b) Insumos Comprados

$$
\mathrm{UI}=\mathrm{VCIU}
$$

onde:

$$
\begin{aligned}
& \mathrm{UI}=\text { Uso Interno do Insumo Comprado na Producão e } \\
& \text { VCIU = Valor Contábil do Insumo Usado. }
\end{aligned}
$$

As consequências da adoção de um Regime de Controle de Estoques Permanente são:

a) O valor e a quantidade fisica dos estoques são permanentemente atualizados e podem ser conhecidos, a qualquer momento, através das Fichas de Estoque.

b) A conta de estoque é movimentada a cada operacão, ou seja, debitada para as entradas e creditada para as saidas do estoque, de forma que seu saldo seja sempre conhecido.

c) Durante o periodo também são movimentadas as contas que representam as entradas e saidas do estoque (Receitas e Despesas Caixa e Não-Caixa). 
d) Sugere-se que seja adotado o Preço Médio Ponderado Móvel como critério de atribuicão de preço ao saldo em estoque. Esse preco médio de mercado deverá ser atualizado depois de cada operação de entrada no estoque. Ou seja:

$$
\mathrm{PST}=\frac{\mathrm{PSN} \times \mathrm{QN}+\mathrm{PME} \times \mathrm{QE}}{\mathrm{QN}+\mathrm{QE}}
$$

onde:

$$
\begin{aligned}
& \text { PST = Preço Médio do Saldo Atual; } \\
& \text { PSN = Preço do Saldo Anterior; } \\
& \text { QN = Quantidade do Saldo Anterior; } \\
& \text { PME = Preco de Mercado da Entrada e } \\
& \text { QE = Quantidade da Entrada. }
\end{aligned}
$$

Esse procedimento também deve ser adotado para os estoques de insumos comprados, o que permite a "atualizacão" de seus precos reais, a cada operacão de compra ou recebimento em espécie.

$$
\text { Determinados produtos agricolas, como a silagem de }
$$
milho, não apresentam um preço de mercado definido devido ao caráter eventual de sua comercializacão. Nesse caso, recomenda-se a conversão da quantidade de silagem em estoque para quilos ou sacas de milho em grão que é, então, valorizado pelo preco de mercado prevalecente, obtendo-se dessa forma o valor de mercado da silagem.

e) O Valor Bruto da Producão Agrícola e o Uso Interno do Produto ou Insumo são informações que podem ser apuradas a qualquer momento, por cálculo direto através da Ficha de Estoque. 
Controle de Ativo Imobilizado

O Ativo Permanente Imobilizado compreende itens com vida útil superior a um ano agricola e que são utilizados nas atividades operacionais da empresa.

A medida que o bem de capital vai sendo usado, ao longo dos periodos sucessivos, ocorre uma perda na sua eficiência funcional devido ao desgaste pelo uso, ação da natureza e obsoletismo. Consequentemente, o custo de aquisicão, formacão ou construcão desse ativo deverá ser distribuido pelos periodos de sua vida útil. Isso é feito através de um procedimento contábil denominado Depreciação (IUDICIBUS et alii, 1983; MARION, 1986).

Assim, a depreciacão é apropriada, em cada periodo contábil, como um Custo Fixo Direto ou Indireto, quando o bem participa diretamente da producão ou como Despesa Operacional, quando isso não ocorre.

Neste Modelo, para a maioria dos bens de capital, foi adotado o Método de Depreciação Linear ou da Linha Reta devido à sua simplicidade de cálculo e funcionamento. De acordo com este método, a quota de depreciacão do periodo é constante e pode ser calculada pela seguinte fórmula:

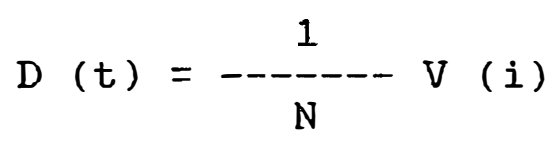

onde:

$D^{\prime}(t)=$ Depreciacão no periodo $t$, em valor monetário real;

$\mathrm{N} \quad=$ Número de periodos da vida útil do bem de capital; 
$V$ (i) - Valor real de aquisição, construcão ou formacão do bem de capital.

Assim, em um dado ponto no tempo, o valor contábil de qualquer desses bens de capital é igual à diferenca entre o seu valor real de aquisicão e sua depreciacão acumulada até aquela data, ou seja:

$$
\operatorname{VCO}(t)=\operatorname{VA}(t-n)-n D(t)
$$

onde:

$\begin{aligned} & \operatorname{VCO}(t)= \text { Valor Contábil real do bem de capital no } \\ & \text { mês } t ;\end{aligned}$

VA $(t-n)=$ Valor de Aquisicão real do bem de capital no mês $t-n$;

n $D(t)=$ Depreciacão Acumulada real do bem de capital, do mês de aquisicão até o mês $t$.

Sugere-se que sejam controlados, por este método os seguintes bens de capital:

- Veiculos, Maquinaria, Equipamentos e Implementos;

- Construcões, Instalacões e Melhoramentos e

- Culturas Perenes.

Como foi dito, os Animais Reprodutores serão avaliados pelo preco de mercado. Nesse caso, o resultado do cálculo (Valor Real Inicial - Valor Real Final + Compras - Vendas) poderá ser positivo se houver depreciação no periodo, ou então negativo, representando uma apreciacão do animal reprodutor.

O Controle de Ativo Imobilizado será realizado,
extracontabilmente, através do software "DEPRECIA", já
desenvolvido para esta finalidade.


A partir de dados fornecidos pelo usuário (Tabela 8), serão estimados as depreciacões e os ganhos ou perdas de capital (Tabela 9), os quais serão posteriormente transferidos para o Balanco Patrimonial e para os Demonstrativos de Resultados. 


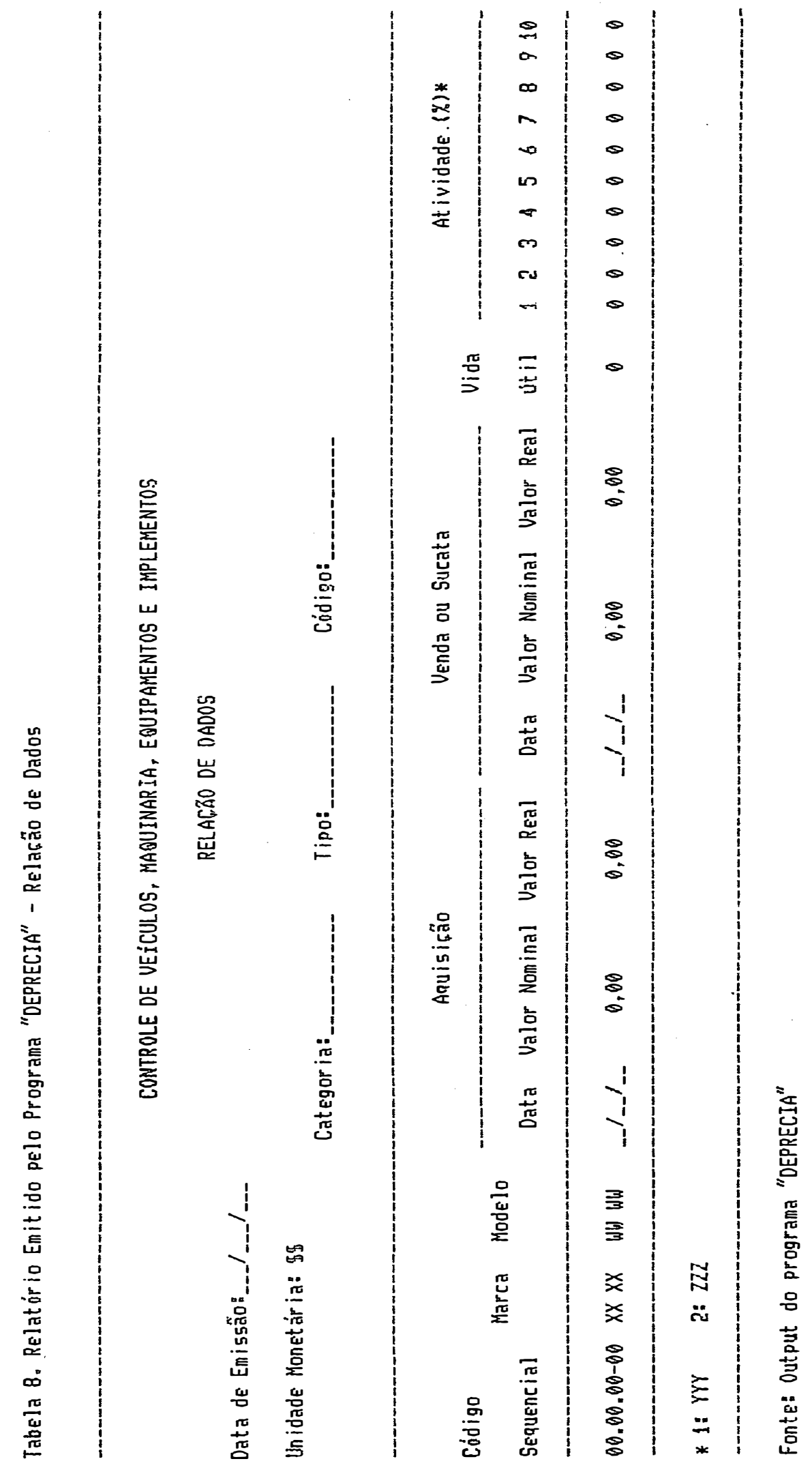




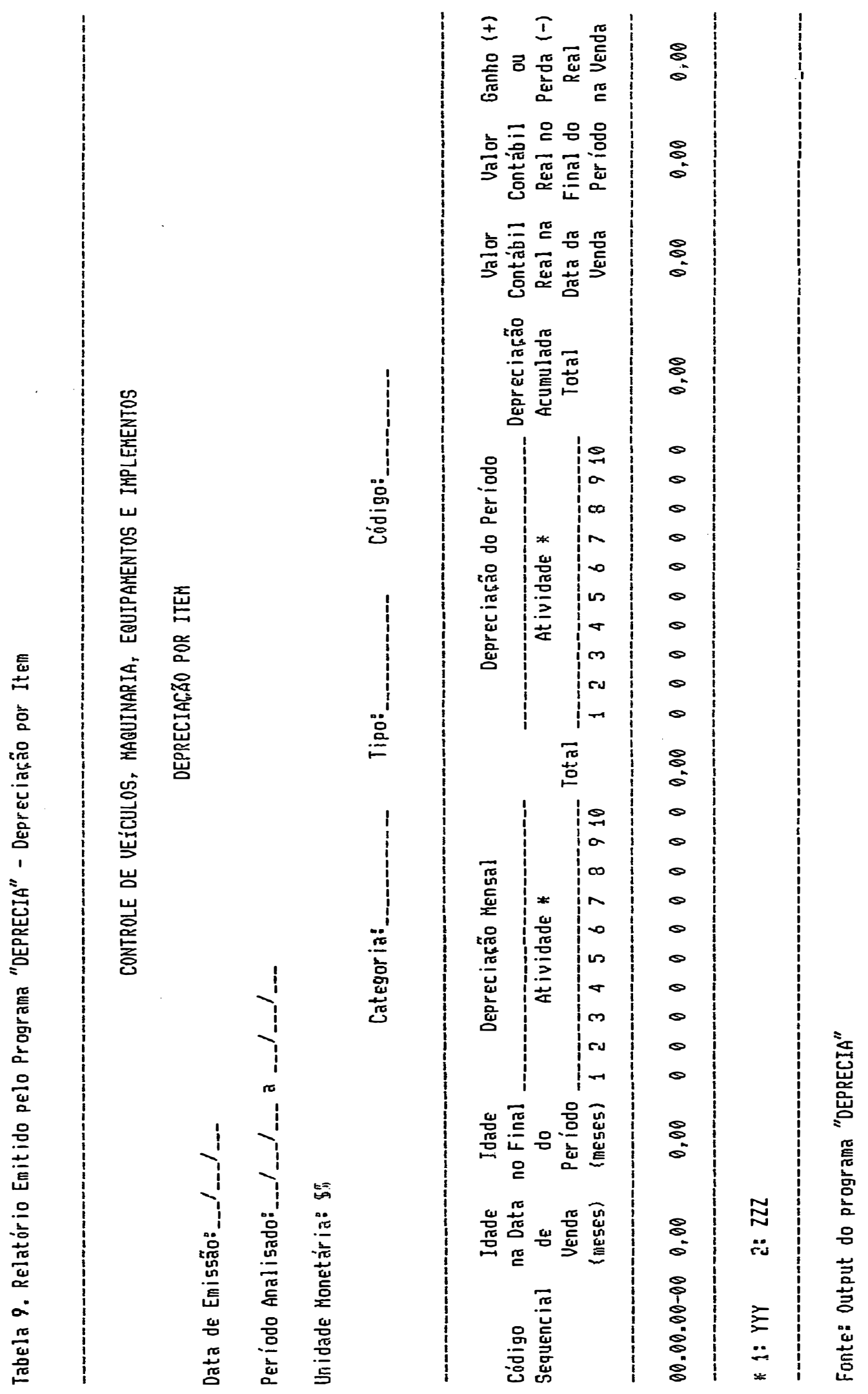




\subsection{Elementos Básicos do Sistema Contábil}

Nesta seç̃o são apresentadas as alternativas escolhidas entre as diferentes formas de se coletar e processar os dados que entram no sistema contábil. As opcões foram feitas em funcão das informações de saida definidas anteriormente, como o conjunto de relatórios contábeis propostos pelo Modelo.

3.2.1. O Processo de Escrituracão Contábil

No teste do Modelo proposto será adotado o processo de escrituracão manual para um maior detalhamento, facilitando a verificacão de possiveis pontos de estrangulamento na operacionalização do sistema.

$\mathrm{Na}$ segunda fase do Projeto "Uso do Microcomputador na Contabilidade Rural", do qual este trabalho faz parte, será elaborado um programa de microcomputador para o Modelo já testado, juntamente com toda a documentacão necessária à sua utilização.

\subsubsection{O Periodo Contábil}

Considerando-se que este Modelo está voltado para fins internos gerenciais, suas informacões deverão ser apresentadas com maior frequência, dando o respaldo necessário às tomadas de decisões.

Entretanto, vale lembrar que a utilizacão do microcomputador permite a elaborạão dos demonstrativos 
financeiros a menores intervalos de tempo, dando aos empresários condicões de avaliar com maior rapidez o grau de acerto ou desacerto de suas decisões passadas, bem como de fixar novas diretrizes e metas para suas atividades futuras.

Isso é particularmente útil no controle de custos, ao longo do ciclo operacional das culturas e criaçoes, através da elaboração mensal de relatórios da Demonstração do Resultado por Atividade de Producão Individual (DRA).

Também poderão ser elaborados relatórios mensais de Fluxo de Caixa (FC), como componentes de grande importância para o controle financeiro da empresa global.

Para que os relatórios da DRE e BP sejam mais significativos, o periodo contábil deverá ser suficientemente longo de forma a abranger os ciclos operacionais completos da maioria das atividades produtivas. Como regra geral, a obtencão desses demonstrativos deve coincidir com o encerramento do ano agrícola.

E importante destacar que, para haver comparabilidade entre os demonstrativos, deve-se manter a consistência do período contábil escolhido. Caso contrário, podem ocorrer informacões não comparáveis entre si, prejudicando a análise de tendência da empresa.

Embora a empresa rural possa escolher livremente o seu periodo contábil, o Modelo proposto neste estudo estabelece que o mesmo não deverá ultrapassar um ano e que a menor unidade de 
tempo para se obter qualquer relatório equivale a um mês.

\subsubsection{O Regime Contábil}

A escrituração feita pelo Regime Contábil de Caixa permite uma maior economia fiscal já que oferece a possibilidade de se "retardar" a renda efetivamente obtida no periodo em questão, para o periodo seguinte. Entretanto, não é esse o objetivo deste Modelo.

Além disso, a escrituracão executada por esse regime é incompleta e inadequada para fins gerenciais, pois não registra as transações à prazo e outras transacões não-caixa. Dessa forma, não apresenta o verdadeiro resultado gerado pelas atividades da empresa durante o periodo.

A maioria das universidades norte-americanas que assistem empresas rurais, adota o Regime Contábil de Caixa. Entretanto, são feitos ajustes para apropriação das parcelas de determinadas transações não-caixa que equivalem ao periodo em questão, como por exemplo as alterações nas contas de Valores a Receber e Valores a Pagar.

As receitas e despesas não-caixa, apesar de não causarem entradas ou saidas de dinheiro, também acarretam aumentos e diminuicões no Patrimônio Liquido da empresa devendo, dessa forma, ser incluidas na Demonstracão de Resultados.

O Regime Contábil de Competência, normalmente utilizado pelos profissionais de Contabilidade, possibilita o registro 
dessas transacões no periodo em que ocorrem. Dessa forma, no Modelo proposto, a renda é registrada no momento em que a produção é gerada (colheita, nascimento, etc.) ou em que os produtos agropecuários são transferidos para terceiros ou para outras atividades de producão (vendas, consumo interno, pagamentos em espécie, uso interno). Em consequência, o Lucro (ou Prejuizo) Liquido obtido não está diretamente relacionado com a quantia de dinheiro em Caixa e nos Bancos, no final do periodo.

Assim sendo, o Regime de Competência, que é um dos "Principios Contábeis Geralmente Aceitos" de maior validade, possibilita uma comparação adequada entre receitas e despesas de um mesmo periodo contábil e dessa forma, o resultado obtido é mais consistente com a realidade, isto é, o Lucro (Prejuizo) Liquido apurado espelha mais exatamente o verdadeiro desempenho econômico da empresa no periodo em questão.

Por esses motivos, torna-se evidente a opcão de se adotar, neste Modelo, a escrituração pelo Regime Contábil de Competência.

\subsubsection{A Forma de Lançamento}

Método de Partidas Simples (MPS)

As principais vantagens do MPS são:

1) facilidade de implementacão e operação, permitindo ao usuário um entendimento rápido de seu funcionamento;

2) não utiliza uma terminologia técnica especifica, 
adotando a linguagem usual da empresa.

Entretanto, esse método apresenta desvantagens bastante evidentes como:

1) adota, com mais frequência, apenas o Regime Contábil de Caixa não registrando, nesse caso, transacões de receitas ou despesas que não envolvem entradas e saidas de dinheiro. Por exemplo: compras e vendas à prazo;

2) não apresenta uma maneira de verificar a exatidão dos lancamentos já efetuados;

3) não fornece informacões suficientes e objetivas para elaboracão do Balanço Patrimonial, dificultando a determinacão da consistência patrimonial da empresa;

4) permite apenas a elaboracão das Demonstrações de Resultados em Dinheiro, pois normalmente só reconhece receitas e despesas caixa.

Em face dessas restrições, é possivel concluir que o MPS, desenvolvido dentro dos parâmetros acima citados, dificulta a obtencão dos demonstrativos financeiros fundamentais de forma consistente, o que prejudica também a análise de tendência da empresa, vista a precariedade das regras utilizadas, levando a crer que não sejam aplicadas, sistematicamente, ao longo de periodos sucessivos.

Portanto, a simplicidade desse método não é suficiente para compensar suas deficiências, já que ele não permite ao 
usuário uma visão global da empresa no tempo, nem uma clara distincão entre seus aspectos econômicos e financeiros, dificultando a análise, o controle e o planejamento.

Método das Partidas Dobradas (MPD)

As principais vantagens do MPD são:

1) pode adotar os regimes contábeis de Caixa, de Competência ou a combinacão dos dois (regime Híbrido), sem perda de dados;

2) registra, efetivamente, todas as transacões nãocaixa;

3) apresenta diferentes maneiras de verificar a exatidão dos lançamentos efetuados;

4) fornece todas as informacões necessárias à elaboração do Balanço Patrimonial, Demonstracões de Resultados e Fluxo de Caixa;

5) por ser um método universalmente aceito, as instituicões financeiras, em geral, são familiarizadas com seu funcionamento e resultados, o que garante um melhor entendimento entre instituição e empresa.

A única desvantagem evidente do MPD é sua compreensão inicial, pois requer registros mais complexos e em maior volume - que, dentro de um processo de escrituracão manual, talvez acarrete certas dificuldades de operacão ao usuário. 
Entretanto, com a utilização do microcomputador, a escriturąão pelo MPD torna-se menos complicada, cabendo à máquina a execucão das tarefas mais trabalhosas.

Com base em todas essas evidências e levando em conta os objetivos especificos deste trabalho, adotar-se-á a forma de lancamento do Método das Partidas Dobradas.

\subsubsection{O Plano de Contas}

Pode-se afirmar que existe uma certa tendência de padronização da estrutura geral dos Planos de Contas de empresas do mesmo ramo de atividades. Assim sendo, este Modelo propõe um Plano de Contas cuja estrutura genérica permite a contabilizacão dos fatos e transacões mais frequentes no dia-a-dia de uma empresa rural, tomando como base um conjunto representativo de algumas das atividades agricolas e pecuárias mais comuns no meio rural brasileiro.

E certo que, conforme a empresa em questão, algumas contas talvez sejam irrelevantes, em dado momento, e outras devam ser adaptadas ou acrescentadas, mas essas alterações já são previstas pela própria flexibilidade do Plano de Contas apresentado. Tais adaptações serão muito facilitadas com a utilização do "software" do Modelo proposto.

O Elenco de Contas

O Elenco de Contas proposto apresenta uma relação das contas patrimoniais e de resultados que podem ser movimentadas na 
escriturąão das operações correntes, bem como aquelas que provavelmente poderão ser usadas pela empresa no futuro (Tabela 10).

As contas aparecem agrupadas conforme o tipo de elemento que representam e são desdobradas em graus de 1 a 7 para maior profundidade de análise. Cada conta é identificada por um código que facilita substancialmente o processo de escrituração eletrônico.

A Tabela 10 (Elenco de Contas Simplificado) apresenta apenas a relação das contas mais genéricas até o 4o. grau, o que é suficiente para dar uma visão global da estrutura do Plano. Considerando-se a grande extensão do Elenco de Contas Completo, será apresentada, no capitulo seguinte (3.3. O Teste do Modelo Proposto), apenas uma exemplificacão com dados de uma pequena empresa rural.

Do 10. ao 40. grau foi adotada a codificação numérica decimal, ou seja, a cada desdobramento adicionam-se dois algarismos separados por um ponto. A partir do 50. até o 7o. grau é usada uma extensão de três digitos que identifica elementos mais especificos (001 a 009) ou determina a atividade de producão agricola ou animal (100 a 998) ou, ainda, um Centro de Resultados Indiretos (999), como pode ser visto na Tabela 11.

Para possibilitar a inclusão de novas contas, cada grau reserva um determinado número de códigos em aberto, onde várias delas poderão ser criadas conforme as necessidades da empresa. Também é possivel a eliminação das contas consideradas 
Tabela 10. Elenco de Contas Simplificado

EMPRESA RURAL:

GRAU CODIGO
1

11

11.01

11.01 .01

11.01 .02

11.01 .03

11.01 .04

11.02

11.02 .01

11.02 .02

11.02 .03

11.02 .04

11.02 .05

11.03

11.03 .01

11.03 .20

11.03 .30

11.03 .40

11.03 .50

11.03 .60

11.03 .70

11.03 .80

11.03 .90

11.04

11.04 .01

11.04 .02

11.04 .03

11.04 .04

12

12.01

12.01 .01

12.01 .02

12.01 .03

12.01 .04

12.01 .05

12.02

12.02 .01

12.02 .02

12.02 .03

12.02 .04

13

13. 01

13. 01.01

13.01 .02

13.01 .03

13.01 .04
NOME DA CONTA

\author{
ATIVO \\ CIRCULANTE \\ DISPONIVEL
}

Caixa

Bancos - Conta Corrente

Aplicações Financeiras

Outros

CREDITOS A CURTO PRAZO

Titulos a Receber a Curto-Prazo

Contas a Receber a Curto-Prazo

Adiantamentos e Empréstimos

Aplicacões Financeiras de Curto-Prazo

Outros Créditos a Curto Prazo

ESTOQUES

Estoques da Produção

Estoques de Sementes e Mudas

Estoques de Fertilizantes e Corretivos

Estoques de Defensivos

Estoques de Alimentos Volumosos

Estoques de Alimentos Concentrados

Estoques de Medicamentos e Vacinas

Estoques de Materiais de Consumo

Estoques de Outros Insumos e Materiais de Consumo

DESPESAS ANTECIPADAS A CURTO PRAZO

Despesas Antecipadas c/ Seguros

Despesas Antecipadas com Juros

Despesas Antecipadas c/ Aluguéis

Outras Despesas Antecipadas a Curto Prazo

REALIZAVEL A LONGO PRAZO

CREDITOS A LONGO PRAZO

Titulos a Receber a Longo Prazo

Contas a Receber a Longo Prazo

Adiantamentos e Empréstimos

Aplicações Financeiras de Longo Prazo

Outros Créditos a Longo-Prazo

DESPESAS ANTECIPADAS A LONGO PRAZO

Despesas Antecipadas c/ Seguros

Despesas Antecipadas c/ Juros

Despesas Antecipadas c/ Aluguéis

Outras Despesas Antecipadas a Longo-Prazo

PERMANENTE

INVESTIMENTOS

Participacões em Outras Empresas

Participações em Fundos de Investimentos

Imóveis para Renda ou Futura Utilizacáo

Outros Investimentos 
Tabela 10. Elenco de Contas Simplificado (continuação)

EMPRESA RURAL:

GRAU CODIGO

$\begin{array}{ll}3 & 13.02 \\ 4 & 13.02 .01 \\ 4 & 13.02 .02 \\ 4 & 13.02 .03 \\ 4 & 13.02 .04 \\ 3 & 13.03 \\ 4 & 13.03 .01 \\ 4 & 13.03 .02 \\ 4 & 13.03 .03 \\ 4 & 13.03 .04 \\ 4 & 13.03 .05\end{array}$

12

221

321.01

421.01 .01

421.01 .02

321.02

$4 \quad 21.02 .01$

$4 \quad 21.02 .02$

$3 \quad 21.03$

$4 \quad 21.03 .01$

$4 \quad 21.03 .02$

$4 \quad 21.03 .03$

$4 \quad 21.03 .04$

$3 \quad 21.04$

$4 \quad 21.04 .01$

$4 \quad 21.04 .02$

$4 \quad 21.04 .03$

$4 \quad 21.04 .04$

$4 \quad 21.04 .05$

$3 \quad 21.05$

$4 \quad 21.05 .01$

$4 \quad 21.05 .02$

$4 \quad 21.05 .03$

$4 \quad 21.05 .04$

$4 \quad 21.05 .05$

$4 \quad 21.05 .06$

$3 \quad 21.06$

$4 \quad 21.06 .01$

$4 \quad 21.06 .02$

$4 \quad 21.06 .03$

$4 \quad 21.06 .04$

$4 \quad 21.06 .05$

$3 \quad 21.07$

$4 \quad 21.07 .01$

$4 \quad 21.07 .02$

321.08

\section{NOME DA CONTA}

IMOBILIZADO

Intermediário

Fixo

Depreciacão Acumulada

Imobilizado em Andamento

DIFERIDO

Gastos de Implantacão e Pré-Operacionais

Estudos e Projetos

Melhorias

Outros Ativos Diferidos

Amortização Acumulada

\section{PASSIVO}

CIRCULANTE

FORNECEDORES

Fornecedor A

Fornecedor B

TITULOS A PAGAR

Credor A

Credor B

SALARIOS A PAGAR

Pessoal Administrativo

Mão-de-Obra Permanente

Mão-de-Obra Temporária

Serviços de Terceiros

ENCARGOS SOCIAIS A RECOLHER

IAPAS a Recolher

FGTS a Recolher

Contribuicão Sindical a Recolher

Imposto de Renda na Fonte

Seguro de Vida

IMPOSTOS A PAGAR

ICMS a Pagar

ISS a Pagar

PIS a Pagar

PRORURAL a Pagar

ITR a Pagar

Imposto de Renda na Fonte - Terceiros CONTAS A PAGAR

Energia Elétrica

Agua

Telefone, Telex e Fax

Aluguéis e Arrendamentos

Outras Contas a Pagar

EMPRESTIMOS A PAGAR

Banco A

Banco B

OUTRAS OBRIGACOES DE CURTO PRAZO 
Tabela 10. Elenco de Contas Simplificado (continuação)

EMPRESA RURAL:

GRAU CODIGO

$\begin{array}{ll}2 & 22 \\ 3 & 22.01 \\ 4 & 22.01 .01 \\ 4 & 22.01 .02 \\ 3 & 22.02 \\ 4 & 22.02 .01 \\ 4 & 22.02 .01 \\ 3 & 22.03 \\ 2 & 23 \\ 3 & 23.01 \\ 4 & 23.01 .01 \\ 4 & 23.01 .02 \\ 3 & 23.02 \\ & \\ 4 & 23.02 .01 \\ 4 & 23.02 .02\end{array}$

$\begin{array}{ll}1 & 3 \\ 2 & 31 \\ 2 & 32 \\ 3 & 32.01 \\ 2 & 33\end{array}$

$\begin{array}{ll}1 & 4 \\ 2 & 41 \\ 3 & 41.01 \\ & \\ 4 & 41.01 .01 \\ 4 & 41.01 .02 \\ 4 & 41.01 .03 \\ 4 & 41.01 .04 \\ 4 & 41.01 .05 \\ 4 & 41.01 .06 \\ 3 & 41.02 \\ & \\ 4 & 41.02 .01 \\ 4 & 41.02 .02 \\ 4 & 41.02 .03 \\ 4 & 41.02 .04 \\ 4 & 41.02 .05 \\ 3 & 41.03 \\ & \\ 4 & 41.03 .01 \\ 4 & 41.03 .02 \\ 4 & 41.03 .03 \\ 4 & 41.03 .04\end{array}$

NOME DA CONTA

EXIGIVEL A LONGO-PRAZO

FINANCIAMENTOS

Banco A

Banco B

TITULOS A PAGAR A LONGO PRAZO

Credor A

Credor B

OUTRAS OBRIGACOES A LONGO-PRAZO

RESULTADOS DE EXERCICIOS FUTUROS

RECEITAS ANTECIPADAS

Receita A

Receita B

CUSTOS OU DESPESAS DAS RECEITAS

ANTECIPADAS

Custo ou Despesa da Receita A

Custo ou Despesa da Receita B

PATRIMONIO LIQUIDO

CAPITAL

RESERVAS

RESERVAS DE REAVALIACAO

LUCROS (OU PREJUIZOS) ACUMULADOS

RECEITAS

RECEITAS OPERACIONAIS

RECEITA OPERACIONAL BRUTA -

INVENTARIO PERMANENTE

Vendas de Produtos Agropecuários

Consumo Interno de Produtos Agropecuários

Pagamentos em Espécie c/ Produtos Agrop.

Uso Interno de Produtos Agropecuários

Acréscimos nos Estoques Devidos à Produção

Alteraç̃es de Preços Reais dos Estoques

RECEITA OPERACIONAL BRUTA -

INVENTARIO PERIODICO

Vendas de Produtos Agropecuários

Consumo Interno de Produtos Agropecuários

Pagamentos em Espécie c/ Produtos Agrop.

Uso Interno de Produtos Agropecuários

Variações dos Estoques no Periodo

(Estoque Final - Estoque Inicial)

RECEITA OPERACIONAL BRUTA -

APROPRIACAO DIRETA

Vendas de Produtos Agropecuários

Consumo Interno de Produtos Agropecuários

Pagamentos em Espécie c/ Produtos Agrop.

Uso Interno de Produtos Agropecuários 
Tabala 10. Elenco de Contas Simplificado (continuą̧ão)

EMPRESA RURAL:

GRAU CODIGO$$
3
$$

4
41.04

41.04 .01

41.04 .02

41.04 .03

41.04 .04

41.05

41.05 .00

41.05 .01

41.05 .02

41.05 .03

41.05 .04

41.05 .05

41.05 .06

41.06

41.06 .00

41.06 .10

41.06 .11

41.06 .12

41.06 .13

41.06 .20

41.06 .21

41.06 .22

42

42.01

42.01 .01

42.01 .02

42.01 .03

42.01 .04

42.01 .05

42.02

42.02 .01

42.02 .02

43

43.00

43.00 .00

43.01

43.02

43.03

43.04

43.05

43.06

43.08

43.09

\section{NOME DA CONTA}

RECEITA OPERACIONAL BRUTA

PRESTACOES DE SERVICOS

Aluguel de Veiculos, Maquinaria,

Equipamentos e Implementos

Aluguel de Animais de Trabalho

Servicos de Mão-de-Obra

Outras Prestacões de Servicos

RECEITA OPERACIONAL BRUTA - TOTAIS

Receita Operacional Bruta - Totais

Vendas de Produtos Agropecuários

Consumo Interno de Produtos Agropecuários

Pagamentos em Espécie c/ Produtos Agrop.

Uso Interno de Produtos Agropecuários

Alteracões dos Estoques no Periodo

Prestacões de Servicos

RECEITAS FINANCEIRAS

Receitas Financeiras

Receitas Financeiras (Juros e Correcão)

Receitas de Titulos a Receber

Receitas de Aplicacões Mercado Financeiro Outras Receitas Financeiras

Ganhos (Perdas) nos Créditos Operacionais Ganhos nos Créditos Operacionais

(-)Perdas nos Créditos Operacionais

DEDUCOES DE RECEITAS OPERACIONAIS

DEDUCOES DA RECEITA OPERACIONAL BRUTA-

INVENTARIO PERMANENTE

Valor Contábil do Produto Vendido

Valor Contábil do Produto Consumido

Valor Contábil do Produto p/ Pagamento

Valor Contábil do Produto Usado

Valor Contábil das Perdas e Mortes

DEDUCOES DA RECEITA OPERACIONAL BRUTA-

INVENTARIO PERIODICO

Compras de Produtos Agropecuários

Recebimentos em Espécie de Prod. Agrop. RECEITAS NAO-OPERACIONAIS

RECEITAS NAO-OPERACIONAIS

Receitas Não-Operacionais

GANHOS NAS VENDAS DE BENS DE CAPITAL

ALUGUEIS E ARRENDAMENTOS

RECEITAS DE TRABALHO FORA DA EMPRESA

RECEITAS DE EMPRESTIMOS A TERCEIROS

INDENIZACOES DE SEGUROS

RECEBIMENTOS EM ESPECIE

DOACOES E HERANCAS

OUTRAS RECEITAS NAO-OPERACIONAIS 
Tabela 10. Elenco de Contas Simplificado (continuacão)

EMPRESA RURAL:

\section{GRAU CODIGO}

5

51

51. 01

51.01 .00

51.01 .01

51.01 .02

51.01 .03

51.02

51.02 .00

51.02 .01

51.02 .02

51.02 .03

51.02 .04

51.03

4

51.03 .00

51.03 .10

51.03 .11

51.03 .20

51.03 .21

51.03 .22

51.03 .23

51.03 .24

51.03 .25

51.03 .30

51.03 .31

51.04

51.04 .00

51.04 .10

51.04 .11

51.04 .20

51.04 .21

51.04 .22

51.04 .23

51.04 .24

51.04 .25

51.04 .30

51.04 .31

51.05

51.05 .00

51.05 .10

51.05 .11

51.05 .20

51.05 .21

51.05 .22

51.05 .23

51.05 .24
NOME DA CONTA

CUSTOS DE PRODUCAO

CUSTOS VARIAVEIS DE PRODUCAO

MAO-DE-OBRA TEMPORARIA

Mão-de-Obra Temporária

Salários

Encargos Sociais

Outros Pagamentos

SERVICOS DE TERCEIROS

Servicos de Terceiros

Aluguel de Veiculos, Maquinaria, Equipamentos e Implementos

Aluguel de Animais de Trabalho

Servicos de Mão-de-Obra

Outros Servicos de Terceiros

VEICULOS, MAQUINARIA, EQUIPAMENTOS E IMPLEMENTOS

Veic., Maq., Equip. e Impl. (Combustivel, Lubrificantes, Reparos e Manutencão)

Custo em Inventário Permanente Valor Contábil do Insumo Usado

Custo em Inventário Periódico Compras

$(+)$ Recebimentos em Espécie

(-) Vendas

(-)Pagamentos em Espécie

(+)Variação do Estoque no Periodo

Custo em Apropriação Direta Compras

SEMENTES E MUDAS

Sementes e Mudas

Custo em Inventário Permanente Valor Contábil do Insumo Usado

Custo em Inventário Periódico Compras

(+)Recebimentos em Espécie

$(-)$ Vendas

(-)Pagamentos em Espécie

(+)Variacão do Estoque no Periodo

Custo em Apropriacão Direta Compras

FERTILIZANTES E CORRETIVOS

Fertilizantes e Corretivos

Custo em Inventário Permanente Valor Contábil do Insumo Usado

Custo em Inventário Periódico Compras

(+)Recebimentos em Espécie

$(-)$ Vendas

(-)Pagamentos em Espécie 
Tabola 10. Elenco de Contas Simplificado (continuação)

EMPRESA RURAL:

GRAU CODIGO

4

51.05 .25

51.05 .30

51.05 .31

51.06

51.06 .00

51.06 .10

51.06 .11

51.06 .20

51.06 .21

51.06 .22

51.06 .23

51.06 .24

51.06 .25

51.06 .30

51.06 .31

51.07

51.07 .00

51.07 .10

51.07 .11

51.07 .12

51.07 .20

51.07 .21

51.07 .22

51.07 .23

51.07 .24

51.07 .25

51.07 .26

51.07 .30

51.07 .31

51.07 .32

51.08

51.08 .00

51.08 .10

51.08 .11

51.08 .12

51.08 .20

51.08 .21

51.08 .22

51.08 .23

51.08 .24

51.08 .25

51.08 .26

51.08 .30

51.08 .31

51.08 .32

51.09

51.09 .00

51.09 .10

51.09 .11

\section{NOME DA CONTA}

(+)Variação do Estoque no Periodo

Custo em Apropriação Direta Compras

DEFENSIVOS

Defensivos

Custo em Inventário Permanente Valor Contábil do Insumo Usado

Custo em Inventário Periódico Compras

(+)Recebimentos em Espécie

$(-)$ Vendas

(-)Pagamentos em Espécie

(+)Variação do Estoque no Período

Custo em Apropriacão Direta Compras

ALIMENTOS CONCENTRADOS

Alimentos Concentrados

Custo em Inventário Permanente Valor Contábil do Insumo Usado

Valor de Mercado do Produto Usado

Custo em Inventário Periódico Compras

(+)Recebimentos em Espécie

$(-)$ Vendas

(-)Pagamentos em Espécie

(+)Variação do Estoque no Periodo Valor de Mercado do Produto Usado

Custo em Apropriacão Direta Compras

Valor de Mercado do Produto Usado ALIMENTOS VOLUMOSOS

Alimentos Volumosos

Custo em Inventário Permanente

Valor Contábil do Produto Usado

Valor de Mercado do Produto Usado

Custo em Inventário Periódico Compras

(+)Recebimentos em Espécie

(-) Vendas

(-)Pagamentos em Espécie

(+)Variação do Estoque no Periodo Valor de Mercado do Produto Usado

Custo em Apropriacão Direta Compras

Valor de Mercado do Produto Usado MEDICAMENTOS E VACINAS

Medicamentos e Vacinas

Custo em Inventário Permanente Valor Contábil do Insumo Usado 
Tabela 10. Elenco de Contas Simplificado (continuação)

EMPRESA RURAL:

GRAU CODIGO

4

$4 \quad 51.09 .21$

$4 \quad 51.09 .22$

$4 \quad 51.09 .23$

$4 \quad 51.09 .24$

$4 \quad 51.09 .25$

$4 \quad 51.09 .30$

$4 \quad 51.09 .31$

351.10

451.10 .00

$4 \quad 51.09 .10$

$4 \quad 51.09 .11$

$4 \quad 51.09 .20$

$4 \quad 51.09 .21$

$4 \quad 51.09 .22$

$4 \quad 51.09 .23$

$4 \quad 51.09 .24$

$4 \quad 51.09 .25$

$4 \quad 51.09 .30$

$4 \quad 51.09 .31$

351.10

451.10 .00

252

352.01

$4 \quad 52.01 .00$

$4 \quad 52.01 .01$

$4 \quad 52.01 .02$

$4 \quad 52.01 .03$

$4 \quad 52.01 .04$

$4 \quad 52.01 .05$

452.01 .06

352.02

452.02 .00

352.03

$4 \quad 52.03 .00$

$4 \quad 52.03 .01$

$4 \quad 52.03 .02$

352.04

452.04 .00

$4 \quad 52.04 .01$

$4 \quad 52.04 .02$

$4 \quad 52.04 .03$

$4 \quad 52.04 .04$

$4 \quad 52.04 .05$

352.05

$4 \quad 52.05 .00$

$4 \quad 52.05 .01$

$4 \quad 52.05 .02$
NOME DA CONTA

Custo em Inventário Periódico Compras

(+)Recebimentos em Espécie

(-)Vendas

(-)Pagamentos em Espécie

(+)Variação do Estoque no Periodo

Custo em Apropriação Direta Compras

MATERIAIS DE CONSUMO

Materiais de Consumo

Custo em Inventário Permanente

Valor Contábil do Insumo Usado

Custo em Inventário Periódico Compras

(+)Recebimentos em Espécie

$(-)$ Vendas

(-)Pagamentos em Espécie

(+)Variação do Estoque no Período

Custo em Apropriação Direta Compras

OUTROS CUSTOS VARIAVEIS DE PRODUCAO

Outros Custos Variáveis de Producão

CUSTOS FIXOS DE PRODUCAO

MAO-DE-OBRA PERMANENTE

Mão-de-Obra Permanente

Salários

Encargos Sociais

Outros Pagamentos

Custos Não-Caixa com Alimentação

Custos Não-Caixa com Moradia

Outros Custos Não-Caixa

CONSTRUCOES, INSTALACOES E MELHORAMENTOS

Construções, Instalações e Melhoramentos (Reparos e Manutenção)

TAXAS, IMPOSTOS, SEGUROS E LICENCAS

Taxas, Impostos, Seguros e Licenças

Taxas e Impostos

Seguros e Licencas

ALUGUEIS E ARRENDAMENTOS

Aluguéis e Arrendamentos

Aluguel de Pastagens de Terceiros

Uso de Pastagens da Empresa

Uso de Animais de Trabalho

Aluguel de Depósitos e Terreiros

Arrendamento de Terras

DEPRECIACOES

Depreciąões

Depreciacão de Veículos

Depreciacão de Maquinaria 
Tảำ 10. Elenco de Contas Simplificado (continuacão)

EMPRESA RURAL:

GRAU CODIGO

$\begin{array}{ll}4 & 52.05 .03 \\ 4 & 52.05 .04 \\ 4 & 52.05 .05 \\ 4 & 52.05 .06 \\ 4 & 52.05 .07 \\ 3 & 52.06 \\ 4 & 52.06 .00 \\ 2 & 53 \\ 3 & 53.01 \\ 4 & 53.01 .01 \\ 4 & 53.01 .02 \\ 2 & 54\end{array}$

16

261

$3 \quad 61.01$

$4 \quad 61.01 .00$

461.01 .01

$4 \quad 61.01 .02$

361.02

$4 \quad 61.02 .00$

461.02 .01

$4 \quad 61.02 .02$

$4 \quad 61.02 .03$

$4 \quad 61.02 .04$

$4 \quad 61.02 .05$

$4 \quad 61.02 .06$

$4 \quad 61.02 .07$

$4 \quad 61.02 .08$

$4 \quad 61.02 .09$

$4 \quad 61.02 .10$

$4 \quad 61.02 .11$

$4 \quad 61.02 .12$

461.02 .13

361.03

461.03 .00

$4 \quad 61.03 .10$

461.03 .11

$4 \quad 61.03 .12$

$4 \quad 61.03 .13$

$4 \quad 61.03 .14$

$4 \quad 61.03 .15$

$4 \quad 61.03 .16$

$4 \quad 61.03 .17$

$4 \quad 61.03 .18$

$4 \quad 61.03 .20$

$4 \quad 61.03 .21$

$4 \quad 61.03 .22$

\section{NOME DA CONTA}

Depreciacão de Equipamentos e Implementos

Depreciacão de Construcões

Depreciação de Instalações

Depreciacão de Melhoramentos

Depreciacão de Culturas Perenes

OUTROS CUSTOS FIXOS DE PRODUCAO

Outros Custos Fixos de Producão

AJUSTES DE CUSTOS VARIAVEIS E FIXOS

ALTERACOES NOS ESTOQUES DE CULTURAS

Anuais em Crescimento

Perenes em Manutencão

CUSTOS DOS BENS E SERVIÇOS PRODUZIDOS

\section{DESPESAS}

DESPESAS OPERACIONAIS

DESPESAS COM VENDAS

Despesas com Vendas

Provisão para Devedores Duvidosos

Outras Despesas com Vendas

DESPESAS ADMINISTRATIVAS

Despesas Administrativas

Retiradas do(s) Proprietário(s)

Pessoal Administrativo

Veiculos, Maquinaria, Equipamentos e Implementos

Construcões, Instalacões e Melhoramentos

Servicos Profissionais Avulsos

Materiais de Consumo

Taxas, Impostos, Seguros e Licencas

Aluguéis

Energia Elétrica

Agua

Comunicacões

Despesas de Transporte

Outras Despesas Administrativas

DESPESAS FINANCEIRAS

Despesas Financeiras

Despesas Financeiras (Juros e Correcão)

Despesas com Fornecedores

Despesas com Titulos a Pagar

Despesas com Empréstimos Bancários

Despesas com Empréstimos de Terceiros

Despesas com Financiamentos

Despesas Bancárias

Impostos sobre Operacões Financeiras Outras Despesas Financeiras

Perdas (Ganhos) nas Obrigacões Operacionais

Perdas nas Obrigacões Operacionais

(-)Ganhos nas Obrigacões Operacionais 
Tabela 10. Elenco de Contas Simplificado (continuação)

EMPRESA RURAL:

GRAU CODIGO

61.04

461.04 .00

$4 \quad 61.04 .01$

361.05

$4 \quad 61.05 .00$

$4 \quad 61.05 .01$

$4 \quad 61.05 .02$

$4 \quad 61.05 .03$

$4 \quad 61.05 .04$

$4 \quad 61.05 .05$

$4 \quad 61.05 .06$

262

$3 \quad 62.00$

$4 \quad 62.00 .00$

$3 \quad 62.01$

$4 \quad 62.01 .01$

$4 \quad 62.01 .02$

$4 \quad 62.01 .03$

$3 \quad 62.02$

$4 \quad 62.02 .01$

$3 \quad 62.03$

362.03 .01

$3 \quad 62.03 .02$

362.03 .03

362.03

$4 \quad 62.03 .01$

362.04

$4 \quad 62.04 .01$

263

$3 \quad 63.00$

$4 \quad 63.00 .00$

363.01

$4 \quad 63.01 .01$

$3 \quad 63.02$

$4 \quad 63.02 .01$

$4 \quad 63.02 .02$

$4 \quad 63.02 .03$

363.03

$4 \quad 63.03 .01$

$4 \quad 63.03 .02$
NOME DA CONTA

DESPESAS LIQUIDAS FINANCEIRAS

Despesas Liquidas Financeiras

Despesas - Receitas Financeiras

OUTRAS DESPESAS OPERACIONAIS

Outras Despesas Operacionais

Depreciacão de Veiculos, Maquinaria, Equipamentos e Implementos

Depreciacão de Construcões, Instalacões e Melhoramentos

Amortização de Gastos de Implantacão e Pré-Operacionais

Amortizacão de Estudos e Projetos

Amortização de Melhorias

Outras Despesas Operacionais

DESPESAS NAO-OPERACIONAIS

DESPESAS NAO-OPERACIONAIS

Despesas Não-Operacionais

PERDAS NAS VENDAS DE BENS DE CAPITAL

Perdas nas Vendas de Veiculos, Maquinaria, Equipamentos e Implementos

Perdas nas Vendas/Sucata de Construcões, Instalaç̃os e Melhoramentos

Perdas nas Reformas de Culturas Perenes

PERDAS EXTRAORDINARIAS

Secas, Geadas, Tempestades, Granizo, Incêndios, etc.

RETIRADAS EM ESPECIE DE PRODUTOS

Consumo Interno

Pagamento de Servicos de Terceiros

Pagamento de Insumos/Materiais de Consumo Comprados

PROVISAO PARA PERDAS EM INVESTIMENTOS

Provisão para Perdas em Investimentos

OUTRAS DESPESAS NAO-OPERACIONAIS

Outras Despesas Não-Operacionais

OUTRAS DESPESAS

OUTRAS DESPESAS

Outras Despesas

PROVISAO PARA IMPOSTOS

Provisão para Imposto de Renda

PARTICIPACOES E CONTRIBUICOES

Empregados

Administradores

Contribuiç̃os e Doacões

PERDAS (GANHOS) NOS ITENS MONETARIOS

Perdas nos Itens Monetários

(-) Ganhos nos Itens Monetários 
Tabola 10. Elenco de Contas Simplificado (continuação)

EMPRESA RURAL:

GRAU CODIGO

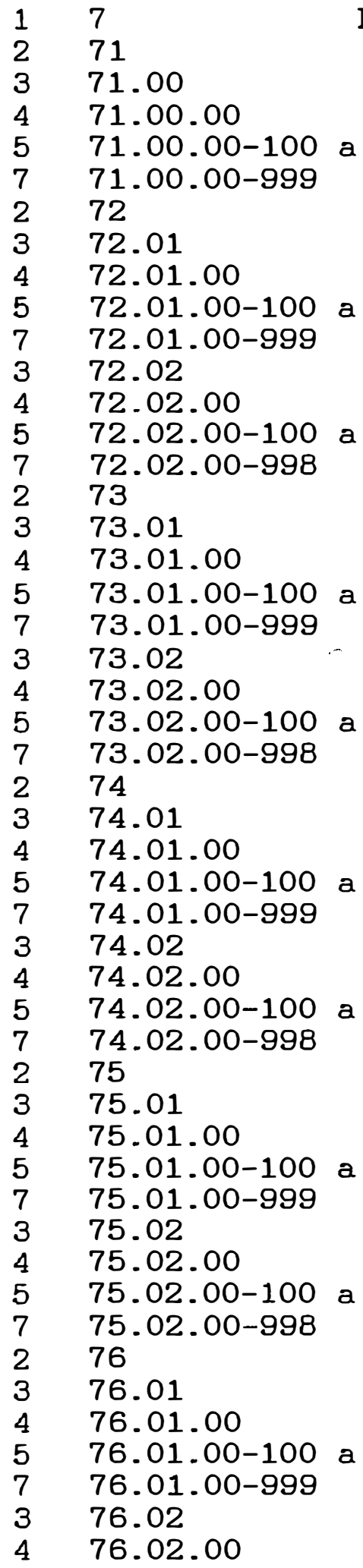

NOME DA CONTA

RESULTADOS

VALOR BRUTO DA PRODUCAO DO PERIODO VALOR BRUTO DA PRODUÇAO DO PERIODO Valor Bruto da Produção do Periodo

Destacar SUB-ELENCO DAS ATIVIDADES

MARGEM SOBRE CUSTOS VARIAVEIS MARGEM SOBRE CUSTOS VARIAVEIS Margem sobre Custos Variáveis

Destacar SUB-ELENCO DAS ATIVIDADES MARGEM S/ CUSTOS VARIAVEIS APOS ALOCACOES Margem s/ Custos Variáveis Ap. Alocacões

Destacar SUB-ELENCO DAS ATIVIDADES LUCRO (PREJUIZO) BRUTO DA PRODUCAAO

LUCRO (PREJUIZO) BRUTO DA PRODUCAO Lucro (Prejuizo) Bruto da Producão

Destacar SUB-ELENCO DAS ATIVIDADES LUCRO BRUTO DA PRODUCAO APOS ALOCACOES

Lucro Bruto da Produção Após Alocações

Destacar SUB-ELENCO DAS ATIVIDADES LUCRO (PREJUIZO) OPERACIONAL LUCRO ( PREJUIZO) OPERACIONAL Lucro (Prejuizo) Operacional

Destacar SUB-ELENCO DAS ATIVIDADES LUCRO OPERACIONAL APOS ALOCACOES

Lucro Operacional Após Alocações

Destacar SUB-ELENCO DAS ATIVIDADES LUCRO (PREJUIZO) ANTES DO I.R. LUCRO (PREJUIZO) ANTES DO I.R. Lucro (Prejuizo) Antes do I.R.

Destacar SUB-ELENCO DAS ATIVIDADES LUCRO ANTES DO I.R. APOS ALOCACOES Lucro Antes do I.R. Após Alocações

Destacar SUB-ELENCO DAS ATIVIDADES LUCRO (PREJUIZO) DEPOIS DO I.R. LUCRO (PREJUIZO) DEPOIS DO I.R. Lucro (Prejuizo) Depois do I.R.

Destacar SUB-ELENCO DAS ATIVIDADES LUCRO DEPOIS DO I.R. APOS ALOCACOES Lucro Depois do I.R. Após Alocacões 
Tabela 10. Elenco de Contas Simplificado (continuação)

EMPRESA RURAL:

GRAU CODIGO

NOME DA CONTA

$5 \quad 76.02 .00-100$ a

$7 \quad 76.02 .00-998$

$2 \quad 77$

$3 \quad 77.01$

$4 \quad 77.01 .00$

$5 \quad 77.01 .00-100$ a

$7 \quad 77.01 .00-999$

$3 \quad 77.02$

477.02 .00

$577.02 .00-100$ a

$7 \quad 77.02 .00-998$

Destacar SUB-ELENCO DAS ATIVIDADES
LUCRO (PREJUIZO) LIQUIDO
LUCRO (PREJUIZO) LIQUIDO
Lucro (Prejuizo) LIquido
Destacar SUB-ELENCO DAS ATIVIDADES
LUCRO LIQUIDO APOS ALOCACOES
Lucro Liquido ApÓs Alocąões
Destacar SUB-ELENCO DAS ATIVIDADES


Tabola 11. Sub-Elenco de Contas das Atividades Produtivas

EMPRESA RURAL:

\section{GRAU CODIGO - EXTENSAO \\ A DESTACAR}

6

7

6

7

6

7

6

7

$00.00 .00-100$

$00.00 .00-110$

$00.00 .00-111$

$00.00 .00-120$

$00.00 .00-121$

$00.00 .00-130$

$00.00 .00-131$

$00.00 .00-140$ a

00.00.00-199

5

6

7

6

7

6

7

6

7

$00.00 .00-200$

$00.00 .00-210$

$00.00 .00-211$

$00.00 .00-220$

$00.00 .00-221$

$00.00 .00-230$

$00.00 .00-231$

$00.00 .00-240$ a

00.00.00-299

$00.00 .00-300$

$00.00 .00-310$

$00.00 .00-320$

$00.00 .00-330$

$00.00 .00-340$

$00.00 .00-350$

$00.00 .00-360$

$00.00 .00-370$

$00.00 .00-380$ a

00.00.00-399

$500.00 .00-400$

$500.00 .00-500$ a

$7 \quad 00.00 .00-998$

$7 \quad 00.00 .00-999$
NOME DA CONTA

\author{
Culturas Anuais \\ Milho \\ Em Crescimento \\ Soja \\ Em Crescimento \\ Outras Culturas Anuais \\ Em Crescimento \\ A Destacar \\ Culturas Perenes \\ Café \\ Em Manutenção \\ Laranja \\ Em Manutenção \\ Outras Culturas Perenes \\ Em Manutenção
}

A Destacar

Animais e Produtos Animais

Pecuária de Corte - Fase Cria

Pecuária de Corte - Fase Recria

Pecuária de Corte - Fase Engorda

Pecuária de Leite

Suinocultura

Ovinocultura

Outras Criações

A Destacar

Outras Atividades Agropecuárias

A Destacar

Centro de Resultados Indiretos ${ }^{\text {a/ }}$

a/ Conta exclusiva para aproprią̧̃o de Receitas, Ganhos, Custos, Despesas, Perdas e Resultados do periodo, que não forem diretamente alocáveis às atividades produtivas. 
desnecessárias devido à reduzida chance de serem movimentadas no presente e no futuro.

Outros Componentes do Plano de Contas

As funções das contas mais genéricas do Elenco proposto foram descritas juntamente com os demonstrativos financeiros no capitulo anterior. Já o conteúdo das contas analiticas, de grau mais elevado, pode ser facilmente identificado pelo próprio nome da conta.

0 funcionamento das contas mais importantes será exemplificado no teste do Modelo proposto.

3.2.6. Ajustes

Como foi explicado anteriormente, no Regime Contábil de Competência as receitas e despesas devem ser apropriadas no periodo em que foram geradas, independentemente de ter havido recebimento ou pagamento. Em consequência, há necessidade de serem feitos ajustes ao final de cada periodo contábil para determinação das parcelas que efetivamente competem ao exercicio em questão, isto é, que foram realmente ganhas, produzidas, consumidas ou usadas dentro desse exercicio.

Portanto os "ajustes representam lançamentos contábeis efetuados após o levantamento de um balancete preliminar, para fazer com que todos os eventos e transacões referentes ao periodo contábil que se encerra sejam registrados dentro do mesmo" (GOUVEIA, 1982 P.507). 
Neste Modelo, os principais lancamentos de ajuste referem-se à:

\section{a) Receitas a Receber}

Através do ajuste é registrada uma receita gerada dentro do periodo, mas que ainda não foi recebida. Nesse caso, debita-se uma conta de Ativo (Titulos a Receber, Contas a Receber, Adiantamentos e Empréstimos, etc.) e credita-se uma conta de Receita.

\section{b) Despesas a Pagar}

Por meio do ajuste é registrada uma despesa gerada dentro do periodo, mas que ainda não foi paga. Nesse caso, debita-se uma conta de Despesa e credita-se uma conta de Passivo (Fornecedores, Titulos a Pagar, Empréstimos a Pagar, etc.).

c) Despesas Antecipadas

o lancamento de ajuste permite apropriar como Despesa a parcela dos gastos antecipados que beneficiaram o periodo atual que está sendo encerrado. Nesse caso, debita-se uma conta de Despesa e credita-se uma conta de Ativo (Despesa Antecipada com Seguros, Despesa Antecipada com Juros, Despesa Antecipada com Aluguéis, etc.).

d) Receitas Antecipadas

Com o ajuste é possivel apropriar como Receita a parcela dos recebimentos antecipados equivalente aos servicos já prestados ou bens entregues no periodo em questão. Nesse caso 
debita-se uma conta de Passivo (Receita Antecipada) e credita-se uma conta de Receita.

e) Estoques Controlados por Inventário Periódico

e:1)Culturas Anuais em Crescimento e Culturas Perenes em Manutenção

Nesse caso o ajuste é decorrente da variação no valor desses estoques no periodo (Estoque Inicial - Estoque Final). Assim, se essa diferenca for negativa ( $E F>E I$ ) debita-se uma conta de Ativo (Estoque de Milho em Crescimento, Estoque de Café em Manutenção, etc.) e credita-se uma conta de Custos de Producão (Ajuste de Custos Variáveis e Fixos).

Esse lancamento permite apropriar, no período em questão, somente os custos que efetivamente contribuiram para gerar a producão que entra no estoque. Se ainda não tiver havido colheita, no periodo, os custos de producão são automaticamente anulados pelo ajuste.

Se a diferenca for positiva (EF < EI), credita-se a conta de Estoque e debita-se a conta de Ajuste, de forma que haja - reconhecimento dos custos compativeis com a producão do periodo.

No caso das pastagens, como explicado anteriormente, não serão realizados ajustes e todos os custos para manutencão dessa cultura, durante o periodo, serão confrontados com a renda referente ao "aluguel" do pasto para as atividades de criąão animal (Receita Operacional Bruta = Uso Interno do Produto). 
Produtos Agricolas e Animais em Formacão

A variação desses estoques no periodo (Estoque Final Estoque Inicial) é componente do Valor Bruto da Producão. Assim o ajuste é contabilizado de forma que, se essa variacão for positiva ( $E F>E I$ ), debita-se uma conta de Ativo (Estoque de Milho, Estoque de Café, Estoque de Novilhas, etc.) e credita-se uma conta de Receita (Variações dos Estoques no Periodo). Esse lancamento permite apropriar a renda não-caixa equivalente à produção do periodo em questão.

Se a variação for negativa ( $E F<E I)$, credita-se a conta de Estoque e debita-se a conta Variąão do Estoque no Periodo. Esse ajuste registra a despesa não-caixa gerada pela reducão do estoque no periodo.

Insumos e Materiais de Consumo

A variação desses estoques no periodo (Estoque Inicial - Estoque Final) é componente do Uso Interno. Portanto o ajuste é contabilizado de forma que apenas a parcela efetivamente usada no periodo seja apropriada como Custo de Producão.

Assim, se essa variação for negativa (EF > EI) debitase uma conta de Ativo (Estoque de Sementes e Mudas, Estoque de Defensivos, etc.) e credita-se uma conta de Custos de Producão (Variação do Estoque no Periodo). Isso significa que, durante o periodo em questão, as entradas no estoque do insumo ou material de consumo foram maiores que as saidas.

Se a variacão for positiva ( $E F<E I)$, houve uso do 
insumo ou material de consumo no periodo e, portanto, credita-se a conta de Estoque e debita-se a conta Variacão do Estoque no Periodo.

\section{f) Deprecią̧ão}

Através dos ajustes é possivel distribuir o custo de aquisicão, formacão ou construcão do Ativo Imobilizado pelos periodos de sua vida útil estimada. Esse procedimento, denominado Depreciacão, é feito de forma a apropriar como Custo de Producão ou Despesa Operacional, a parcela referente ao desgaste do bem de capital no periodo em questão.

Assim sendo, debita-se uma conta de Custos de Producão (Depreciacão de Veiculos, Depreciacão de Maquinaria, etc.) ou de Despesa Operacional (Outras Despesas Operacionais) e credita-se uma conta retificativa do Ativo Imobilizado (Depreciąão Acumulada de Veiculos, Depreciacão Acumulada de Maquinaria, etc. ).

\section{g) Amortização}

Por intermédio dos ajustes, os recursos aplicados no Ativo Diferido são distribuidos pelos periodos em que, supostamente, esses gastos trazem beneficios à empresa. Esse procedimento contábil é denominado Amortização e permite registrar como Despesa Operacional a parcela referente à perda da capacidade desse ativo no periodo em questão.

Assim sendo, debita-se uma conta de Despesa Operacional (Outras Despesas Operacionais) e credita-se uma eonta 
retificativa do Ativo Diferido (Amortizacão Acumulada de Gastos de Implantação e Pré- Operacionais, Amortização Acumulada de Melhorias, etc.).

\section{h) Ajustes de Corręão de Saldos}

São representados por todos os lancamentos destinados a corrigir o saldo de contas. Podem-se destacar as alteracões de precos reais nos estoques de produtos, os ganhos ou perdas nas vendas, sucateamento ou reforma de bens de capital, perdas (ganhos) nos itens monetários, reavaliação de itens do Ativo Permanente Imobilizado ao preço de mercado, a conversão e atualização cambial de Disponibilidades e dividas em moeda estrangeira, contabilização de Provisão para Devedores Duvidosos e Provisão para Imposto de Renda, transferências entre contas para corrigir lancamentos indevidos (estornos), contabilizacão de transações ainda não registradas, reversão de reservas realizadas no exercicio, etc. (GOUVEIA, 1982; IUDICIBUS et alii, 1983; MARION, 1986).

\subsubsection{Encerramento de Contas de Receita e Despesa}

Como foi dito anteriormente, o resultado das transações da empresa deve ser apurado ao final de cada periodo contábil. Para isso devem ser confrontados os saldos das contas de Receita, Custo e Despesa que competem ao exercicio em questão.

Esse procedimento contábil é efetuado através do encerramento dessas contas e transferência dos seus saldos para as contas de Resultado do Periodo: Valor Bruto da Producão do 
Periodo, Margem Sobre Custos Variáveis, Lucro Bruto da Producão, Lucro ou Prejuizo Operacional, Lucro ou Prejuizo Antes do I.R., Lucro ou Prejuizo Depois do I.R. e Lucro ou Prejuizo Liquido.

Portanto, todas as contas de Receita, Ganho, Custo, Despesa e Perda são periódicas porque iniciam cada exercicio com saldo zero e os registros que acumulam referem-se apenas ao periodo contábil em questão.

Assim, para se encerrar uma conta de Receita ou Ganho deve-se debitá-la de modo que seu saldo seja transferido para crédito de uma conta de Resultado. No caso de contas de Custo, Despesa ou Perda é necessário creditá-las e debitar a conta de Resultado.

3.2.8. Distribuicão dos Resultados

O confronto das contas de Receita, Ganho, Custo, Despesa e Perda nas contas de Resultado do Periodo obedece aos cálculos apresentados na Tabela 5. Essas contas também são transitórias e devem ser encerradas, no final do periodo, conforme a sequência apresentada na DRE.

A última conta, Lucro Liquido, deve ser debitada e seu saldo transferido para crédito da conta Lucros (Prejuizos) Acumulados do BP. A soma do resultado do período com o saldo anterior de Lucros Acumulados representa o lucro à disposicão, para ser destinado à formacão de reservas e/ou distribuido aos proprietários da empresa. Nesse caso, debita-se a conta Lucros Acumulados e credita-se o Caixa ou Contas a Pagar, no valor 
referente à participacão do(s) proprietário(s) nos lucros. 0 saldo remanescente em Lucros Acumulados, depois dessa operacão, representa o lucro retido na empresa que pode ser usado para aumento do Capital.

Se o resultado foi prejuizo, poderá ser absorvido por lucros retidos ou reservas. Nesse caso, credita-se a conta Prejuizo Liquido e debita-se Lucros Acumulados. Entretanto, se houver saldo devedor remanescente em Prejuizos Acumulados, ele será subtraido da conta Capital, caracterizando-se a descapitalização da empresa.

\subsubsection{0s Livros Contábeis}

\section{Livro Diário}

E o único livro contábil obrigatório por forca de lei e também o mais importante para realizacão da Contabilidade e do ponto de vista fiscal.

Os lançamentos são feitos pela ordem cronológica dos acontecimentos $e$, quando as finalidades são fiscais, apenas à vista de um documento que comprove a legitimidade da operacão (nota fiscal, recibo, titulo, contrato, etc.).

Segundo o Método das Partidas Dobradas, o registro de qualquer operacão deve envolver, no minimo, duas contas: uma que será debitada e outra que será creditada. Escolhidas as contas apropriadas é preciso conhecer o critério de variação do saldo da conta, ou seja, o mecanismo de débito ou crédito (Tabela 12). 
Tabela 12 Mecanismo de Débito e Crédito do Método das Partidas Dobradas

\begin{tabular}{|c|c|c|c|}
\hline CONTA & $\begin{array}{l}\text { NATUREZA } \\
\text { DO } \\
\text { SALDO }\end{array}$ & $\begin{array}{l}\text { VARIACAO } \\
\text { DO } \\
\text { SALDO }\end{array}$ & PROCEDIMENTO \\
\hline Ativo & devedor & $\begin{array}{l}\text { aumenta } \\
\text { diminui }\end{array}$ & $\begin{array}{c}\text { debitada } \\
\text { creditada }\end{array}$ \\
\hline Passivo & credor & $\begin{array}{l}\text { aumenta } \\
\text { diminui }\end{array}$ & $\begin{array}{c}\text { creditada } \\
\text { debitada }\end{array}$ \\
\hline $\begin{array}{l}\text { Patrimônio } \\
\text { Liquido }\end{array}$ & credor & $\begin{array}{l}\text { aumenta } \\
\text { diminui }\end{array}$ & $\begin{array}{l}\text { creditada } \\
\text { debitada }\end{array}$ \\
\hline Receita & credor & aumenta & creditada \\
\hline Despesa & devedor & aumenta & debitada \\
\hline
\end{tabular}

Esse mecanismo é explicado pelo fato de que se uma conta patrimonial (de Ativo, Passivo ou Patrimônio Liquido) sofrer uma variacão favorável ao patrimônio (positiva), com aumento dos bens ou direitos ou diminuicão das obrigacões, ela será debitada. Se sofrer variacão desfavorável ao patrimônio (negativa), com diminuicão dos bens ou direitos ou aumento das obrigações, ela será creditada.

Para as contas de resultado (Receita, Ganho, Custo, Despesa e Perda) o procedimento é o inverso. Com o acréscimo de seu saldo, uma conta de receita deve ser creditada, porque aumenta o patrimônio da empresa, enquanto uma conta de despesa deve ser debitada, pois diminui o patrimônio. 
Neste Modelo, um lancamento no Livro Diário deverá sempre registrar os seguintes dados:

1) data da operacão;

2) conta(s) a ser(em) debitada(s) (nome e código);

3) conta(s) a ser(em) creditada(s) (nome e código);

4) histórico breve da operacão mencionando, quando for o caso, as caracteristicas dos documentos comprobatórios e o nome da pessoa física ou juridica com quem foi realizada a transação.

5) valor da operacão em moeda corrente e valor real.

o registro de uma operacão no Diário é denominado partida de diário. As partidas envolvendo apenas uma conta a débito e uma conta a crédito são as mais comuns e denominam-se partidas de 1a. fórmula. Partidas de 2a. fórmula são compostas de diversas contas devedoras e uma única credora e de $3 a$. fórmula envolvem uma única conta devedora e várias credoras. Entretanto nada impede que sejam feitas, no lugar dessas partidas, diversas partidas de 1a. fórmula. Já a partida de $4 a$. fórmula é pouco comum e envolve várias contas devedoras e credoras.

Como foi dito anteriormente, o teste deste Modelo será feito por escrituracão manual. Assim sendo, adotar-se-á um tipo de Diário semelhante ao encontrado na literatura contábil (ARMBRUSTER, 1983; GOUVEIA, 1982; MARION, 1986). A alteracão no 
seu traçado diz respeito à inclusão de duas colunas, para débito e crédito, que discriminam o valor real de cada operação conforme o tipo de deflator utilizado (Tabela 13).

A utilização do microcomputador, na segunda etapa do referido Projeto, irá dispensar completamente a escrituracão manual do Livro Diário. Para essa finalidade, será adotada uma espécie de "Livro Borrador", como o veiculo dos dados básicos que movimentam todo o sistema contábil. Nesse livro, o usuário deverá registrar, manualmente, um histórico de todos os fatos e transacões contábeis da empresa, com seus respectivos valores correntes.

Periodicamente, esses dados darão entrada no "software", pela transcricão no Livro Diário. Entretanto, será suficiente "informar" o programa sobre os códigos das contas envolvidas $e$ as variacões dos seus saldos causadas pelas transacões, para que seja executado o mecanismo de débito e crédito. Dessa forma, o usuário não necessita saber se o valor a ser lancado deve ser debitado ou creditado.

\section{Livro Razão}

Embora não seja obrigatório, o Livro Razão é indispensável no servico contábil de qualquer empresa. Sua escrituracão é cronológica e sistemática, e consiste em uma simples transcricão dos dados do Livro Diário, de modo que cada conta mostre todos os seus débitos, créditos e seu saldo, até o momento. Este livro viabiliza o levantamento do Balancete de 
Tabela 13. Modelo Proposta de Livro Díaria

EMPGESA FURAL:

IIVKO DIARIO

:ANO:

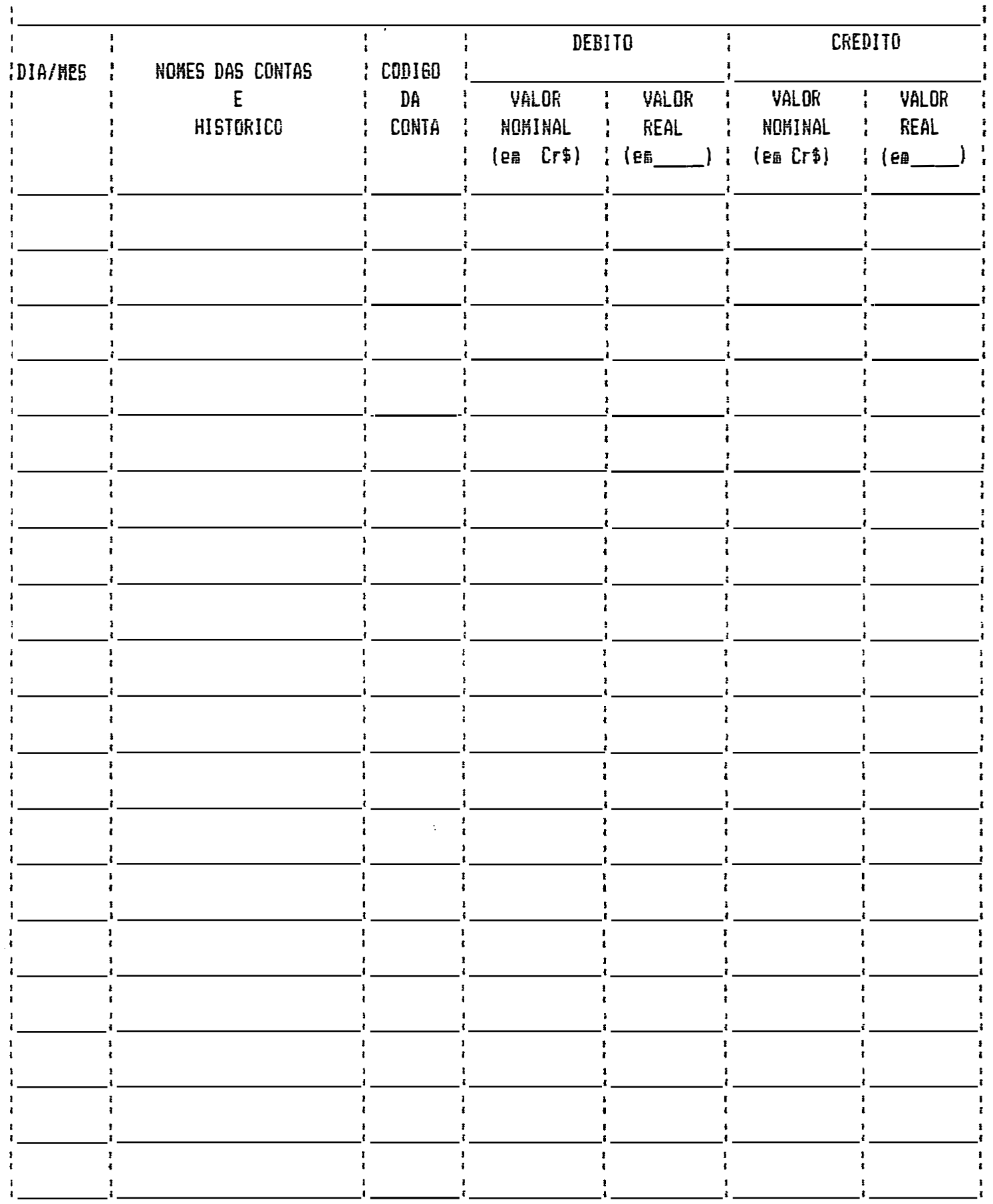


Verificação das contas registradas no Diário.

Neste Modelo, será adotado um tipo de Livro Razão apresentado em fichas avulsas, uma para cada conta (GOUVEIA, 1982; IUDICIBUS et alii, 1983; MARION, 1986). Neste tracado foram adicionadas três colunas para valores reais (Tabela 14).

A representação gráfica do Razão pode ser bastante simplificada visando facilitar as ilustracões e explicações, porém não pode ser usada na escrituração oficial da empresa, que segue o tracado determinado pela Lei.

O tracado simplificado, representado no Esquema 2, recebe o nome de Conta em T, Razão em $T$ ou Razonete e devido à sua praticidade será adotado no teste manual deste Modelo e, depois, no programa de microcomputadores.

Como se pode observar, o Livro Razão não inclui nenhuma informação adicional àquelas obtidas pelo Livro Diário, apenas transcrevendo-as de forma organizada e permitindo o cálculo do saldo de cada conta separadamente. Portanto a utilizacão do microcomputador pode, perfeitamente, dispensar a escrituração manual do Razão, já que o programa deverá executar, a transcricão para os Razonetes automaticamente, de modo que os contas estejam sempre atualizadas. Além da economia de tempo, erros como transcrever a conta errada ou lancar o valor do lado errado da conta, praticamente são eliminados. 


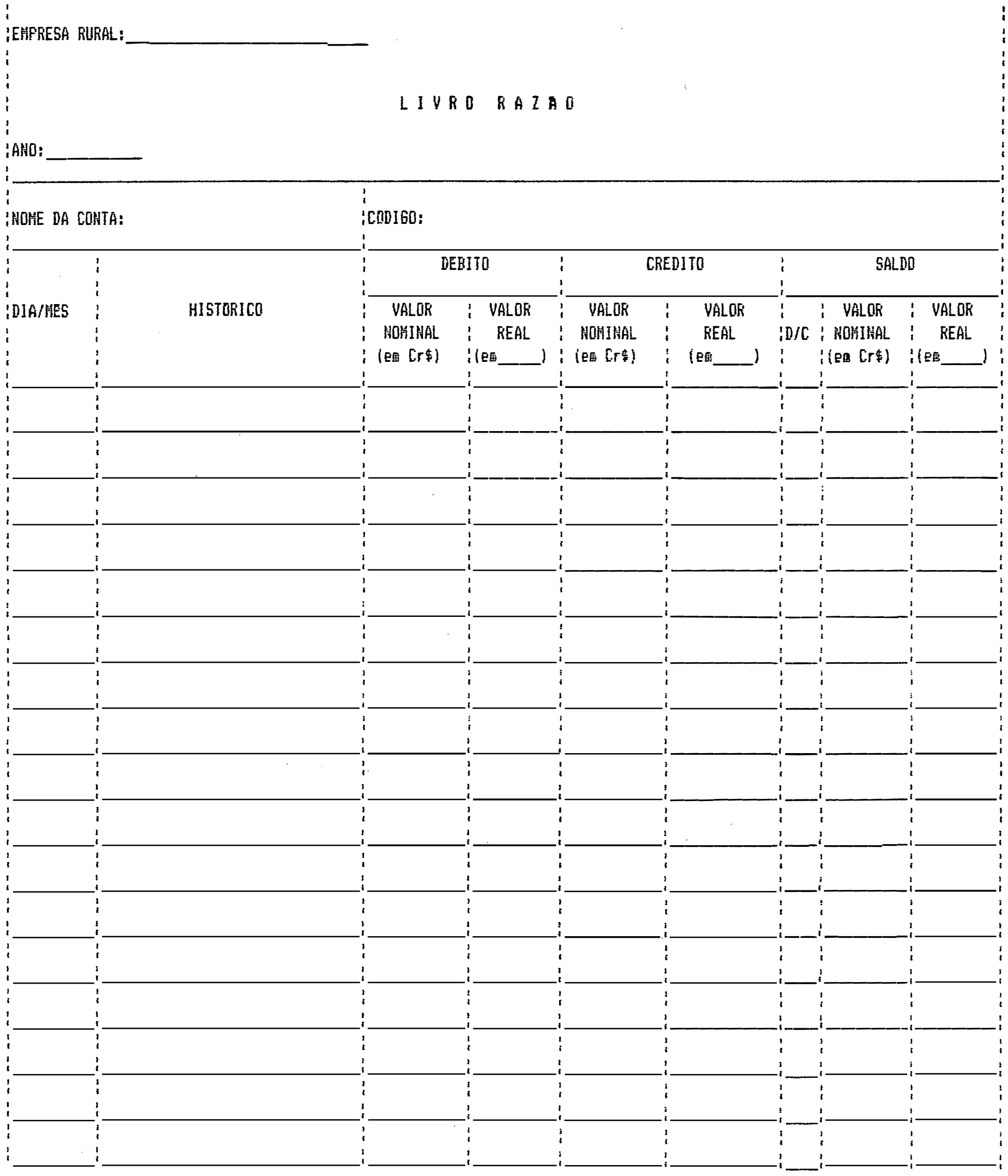


CONTA DE ATIVO

CONTA DE PASSIVO
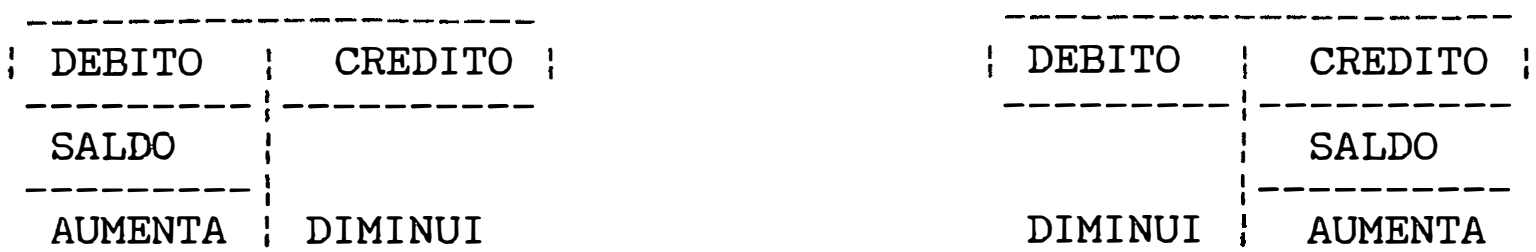

CONTA DE PATRIMONIO LIQUIDO

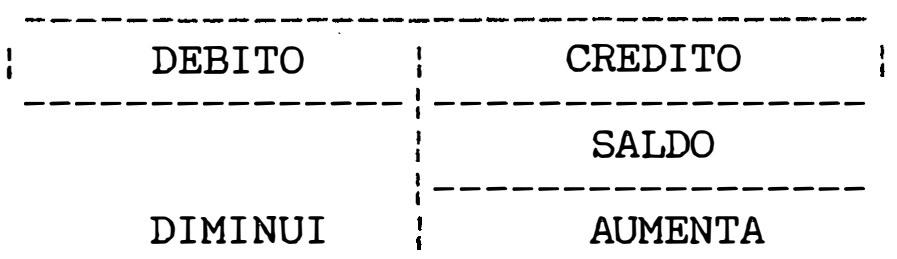

CONTA DE DESPESA

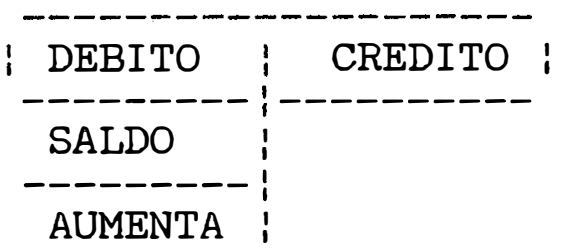

CONTA DE RECEITA

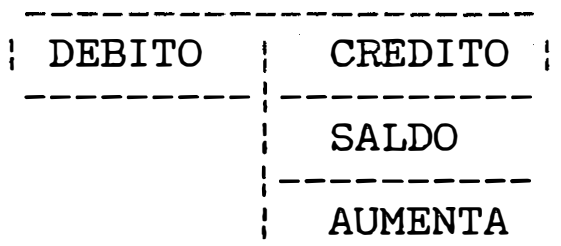

Figura 5. Modelo Proposto de Razonete

\section{Livros Auxiliares do Razão}

Têm a função de fornecer registros mais detalhados sobre as contas coletivas que se referem aos débitos e créditos da empresa para com terceiros.

Neste Modelo, os Razões Auxiliares ou Analiticos serão constituidos por fichas de Razão separadas (Tabela 14), uma para cada conta analitica especifica dos seguintes sub-grupos: Bancos - Conta Corrente, Aplicacões Financeiras, Créditos a Curto e Longo Prazo, Fornecedores, Títulos a Pagar a Curto e Longo Prazo, Salários a Pagar, Contas a Pagar, Empréstimos Bancários, 
Financiamentos e outras obrigacões que exijam um controle mais rigoroso.

Assim, através dessas fichas, o empresário poderá controlar suas transacões com cada devedor ou credor, individualmente, obtendo informacões como: o valor inicial do crédito ou da divida, as amortizacões já realizadas, o saldo a receber ou a pagar, etc..

Um dos livros auxiliares de grande importância é o Livro Caixa que controla as operacões em dinheiro e fornece dados sobre o histórico das transações e seus documentos, que serão utilizados na elaboração do Fluxo de Caixa.

Os livros auxiliares do Razão são particularmente úteis no trabalho de conciliação das contas, em que se faz o confronto entre o saldo (valor) de cada conta patrimonial do Razão com a existência física do componente patrimonial que ela representa. Qualquer diferenca exigirá verificação imediata, caso contrário o Balanço não estará representando, com fidelidade, a situação patrimonial - financeira da empresa.

Portanto deveråo ser confrontados, periodicamente, os saldos nos extratos enviados pelos Bancos com os saldos registrados no Livro de Bancos; as existências de dinheiro em Caixa, com os saldos registrados no Livro Caixa; as duplicatas a receber que se encontram em cobranga e/ou nos Bancos, com os saldos do Livro Duplicatas a Receber e assim por diante.

O uso do microcomputador permitirá que esses registros 
adicionais sejam permanentemente atualizados, na forma de Controles ou Relatórios Extracontábeis, como já foi discutido anteriormente. Essas tabelas poderão ser imprimidas a qualquer momento para conferência imediata das existências ou de outros dados necessários, atribuindo maior exatidão ao sistema e auxiliando o empresário no controle de seus negócios.

\section{Balancete de Verificação.}

E um documento imprescindivel para levantamento do Balanço Patrimonial e sua estrutura parte do principio de que a soma dos saldos devedores é igual à soma dos saldos credores, obedecendo ao Método das Partidas Dobradas. Essa igualdade significa. que os registros feitos nos livros Diário e Razão estão corretos e assim os saldos das contas poderão ser apresentados no Balanco Patrimonial.

Entretanto, se no fechamento do Balancete ocorrerem diferencas entre as somas dos saldos devedores e credores, estas deverão ser imediatamente investigadas e corrigidas, através de conferências das partidas do Diário e das transcrições do Razão, antes que se proceda ao levantamento do Balanço.

O Balancete mais simples apresenta apenas as contas do Livro Razão, movimentadas ou não no periodo, e seus respectivos saldos devedores ou credores. Este Modelo propõe um Balancete mais completo (Tabela 15) que mostra os saldos do Balancete anterior, o movimento de débitos e créditos do período e os saldos atuais, permitindo comparaẽ̃es entre os valores, tanto 
Tabela 15. Modelo Proposto de Balancete de Verificaçăo

IEHPRESA RULRAL:

DALANCETE DE VERIFICACAO

DATA:

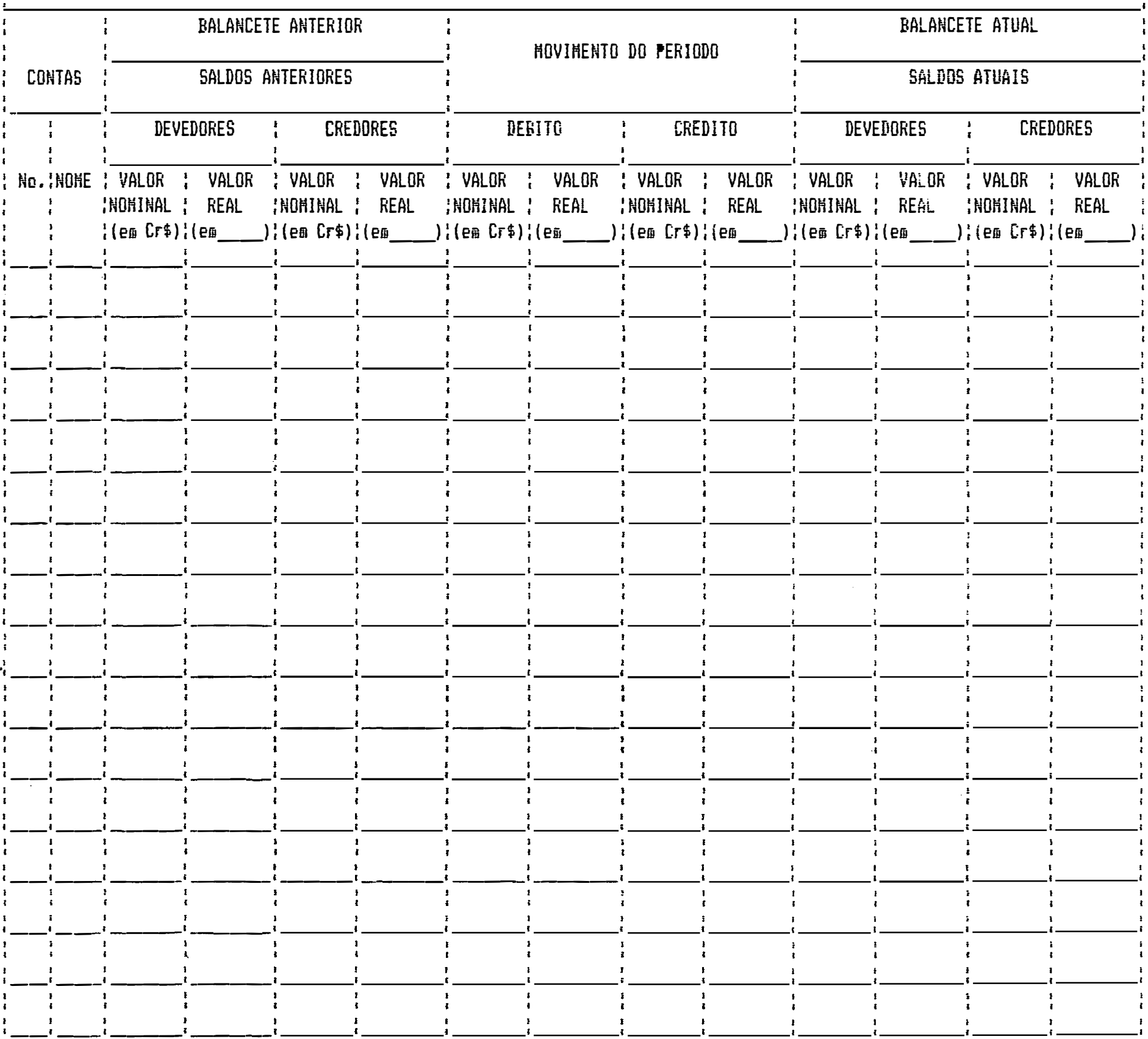


nominais como reais. Quando uma conta não tiver sido movimentada no periodo, não apresentará débito ou crédito, mas seu saldo deve, assim mesmo, estar relacionado no Balancete para que apareca no Balanco Patrimonial.

O levantamento do Balancete de Verificação deverá ser feito pelo menos uma vez por mês, evitando assim que possiveis erros de escrituracão ou cálculo sejam acumulados durante muito tempo, o que dificultaria as correcões. Quanto menor for o periodo verificado, tanto mais fácil será a localizacão dos erros. Esse procedimento poderá ser bastante simplificado com o uso do microcomputador que deverá ser programado para elaborar balancetes a qualquer momento, de maneira rápida e eficiente. Na constatação de diferencas poderão ser verificadas as transcricões no Razão ou então imprimidas relacões dos lancamentos feitos no Diário, simplificando o trabalho de averiguacão.

\subsubsection{O Tratamento da Inflação pelo Sistema Contábil}

Como foi explicado anteriormente, uma das principais finalidades deste Modelo é gerar relatórios contábeis que fornecam uma imagem realista e atualizada da situação econômicofinanceira da empresa. Nesse sentido, para se contornar o problema inflacionário, são sugeridas as seguintes alternativas em resposta às questões relacionadas no item 2.2.7. (Contabilidade e Inflação):

a) Que tipo de valor se pretende obter

E imprescindivel que as informacões obtidas nos 
relatórios sejam expressas em valores com poder aguisitivo constante (valores reais), de forma que haja comparabilidade entre os mesmos.

b) Qual o grau de detalhamento para o ajustamento dos registros originais

o ajustamento dos dados de entrada no sistema é feito em todos os livros contábeis adotados neste Modelo (Livro Diário, Livro Razão, Livros Auxiliares do Razão e Balancete de Verificação) através de colunas para valores reais sem, contudo, eliminar as colunas de valores nominais, como pode ser visto nas Tabelas 13, 14 e 15 .

Esse procedimento permite que os cálculos possam ser efetuados com dados expressos em moeda do mesmo poder aquisitivo e, dessa forma, é possivel apresentar as informações de saida também em valores reais, como pode ser visto no BP (Tabela 4), DRE e DRAs (Tabela 5), Ficha de Estoque (Tabela 7) e nas Tabelas de Depreciação (Tabelas 8 e 9 ).

c) Como proceder

O procedimento contábil consiste em transformar os dados coletados em valores nominais (correntes) para valores reais, através do emprego de um deflator de acordo com as seguinte fórmulas:

c.1) Deflator = BTN (Bônus do Tesouro Nacional)

$$
\operatorname{VR}(t)=\frac{\operatorname{VN}(t)}{\operatorname{VNB}(t)}
$$


onde:

$V R(t)=$ valor do dado coletado, em número de BTNs, no mês $t$;

VN $(t)=$ valor nominal do dado coletado, em Cr\$, no mês $t$;

$\operatorname{VNB}(t)=$ valor do $B T N$, em $\operatorname{Cr} \$$, no mês $(t)$.

c.2) Deflator = Taxa de Câmbio $(\operatorname{Cr} \$ /$ US $\$ 1,00)$

$\operatorname{VR}(t)=\frac{\operatorname{VN}(t)}{\operatorname{VTX}(t)}$

onde:

$V R(t)=$ valor do dado coletado, em dólares, no mês $t$;

VN $(t)$ = valor nominal do dado coletado, em $\operatorname{Cr} \$$, no mês t;

$\operatorname{VTX}(t)=$ valor da taxa de câmbio, em $\operatorname{Cr} \$ / U S \$ 1,00$, no mês $(t)$.

c.3) Deflator = IGP (Indice Geral de Precos)

Este indice poderá ser o da Fundação Getúlio Vargas (Indice "2" da Conjuntura Econômica), O IPC (Indice de Preços ao Consumidor do IBGE) ou outro indice selecionado pela empresa.

$$
V R(t)=V N(0) \times \frac{\operatorname{IGP}(0)}{\operatorname{IGP}(t)}
$$

onde:

$$
\begin{aligned}
\text { VR }(t)= & \text { valor real do dado coletado, em cruzeiros do } \\
& \text { mês } t ; \\
\text { VN }(0)= & \text { valor nominal do dado coletado, em cruzeiros } \\
& \text { correntes do mês } 0 ; \\
\text { IGP }(0)= & \text { valor do IGP no mês } 0 ; \\
\text { IGP }(t)= & \text { valor do IGP no mês } t .
\end{aligned}
$$


Como foi dito no capitulo anterior, um elemento que surge como consequência da inflacão refere-se às perdas ou ganhos não-realizados nos itens monetários (Caixa, Bancos, Aplicacões no Mercado Financeiro, Créditos e Obrigacões), calculados a partir dos saldos dessas contas apresentadas no Balancete de Verificacão.

Esses ganhos ou perdas devem ser apropriados pela DRE, para que sejam computados no cálculo do valor real Lucro Liquido, como pode ser visto na Tabela 5.

\section{d) Como interpretar os valores e demonstrativos resultantes}

A interpretacão dos relatórios contábeis expressos em valores reais segue as explicacões do capitulo anterior. Dessa maneira é possivel tomar decisões fundamentadas em informacões coerentes com a realidade econômico-financeira da empresa.

\subsubsection{Procedimentos Contábeis}

O processo de elaboracão dos relatórios contábeis inicia-se com o levantamento de um inventário e caminha por uma sequência de passos lógicos, ou procedimentos, que interligam as atividades envolvidas no ciclo de coleta e processamento dos dados, resultando finalmente em um conjunto de informacões de saida (BIO, 1985).

Neste Modelo, o roteiro dos procedimentos contábeis do Método das Partidas Dobradas pode ser organizado da seguinte maneira (IUDICIBUS et alii, 1983; MARION, 1986): 
1) Levantamento do Inventário que, em sentido amplo, consiste num processo de verificacão, descricão e avaliacão de todas as existências na empresa, ou seja, de todos os seus bens, direitos e obrigacões.

O Inventário deve ser iniciado pelo Ativo Circulante com o levantamento de todos os bens em Estoque, seguindo as etapas determinadas para o Inventário Periódico ou mediante o preenchimento das Fichas de Estoque (Tabela 7), para os itens controlados por Inventário Permanente. Visando uma maior organizacão, os dados do Inventário Periódico também poderão ser registrados em fichas, como as que serão apresentadas no capitulo seguinte (3.3. O Teste do Modelo Proposto).

Em seguida, procede-se a coleta de dados com respeito aos itens do Ativo Imobilizado e Diferido, através do preenchimento das fichas ilustradas nas Tabelas 8 e 9 . Dessa forma são obtidos os custos reais de aquisicão, formacão ou construcão, assim como as Depreciacões e Amortizações Acumuladas até a data do Balanço.

Finalmente, são levantados os dados referentes a todas as outras existências da empresa, para que seja possivel elaborar seu Balanco Patrimonial Inicial.

2) Elaboração do Plano de Contas especifico da empresa em questão a partir dos Elencos de Contas apresentados nas Tabelas 10 e 11 .

3) Lancamentos no Livro Diário registrando, em uma 
primeira etapa, todos os itens patrimoniais levantados pelo Inventário (bens, direitos e obrigacões) e, posteriormente, cada fato ou transacão contábil ocorrido durante o periodo.

4) Transcrições dos registros do Diário para os Razonetes.

5) Levantamento do primeiro Balancete de Verificacão com os saldos devedores e credores das contas patrimoniais.

6) Lançamentos dos Ajustes do periodo (Receitas a Receber, Despesas a Pagar, Custos, Despesas e Receitas Antecipados, Variacões dos Estoques com Controle Periódico, Depreciações e Amortizações, Ajustes de Correcão de Saldos).

7) Levantamento do Balancete de Verificacão Após Ajustes.

8) Encerramento de todas as contas de Receitas, Ganhos, Custos, Despesas e Perdas, para apuração dos Resultados do Periodo. Posteriormente, distribuicão do Lucro (Prejuizo) Liquido.

9) Levantamento do Balancete de Verificacão Após Encerramento.

10) Elaboração do Balanço Patrimonial Final, Demonstracões de Resultados, Fluxo de Caixa e complementacão dos Informativos Adicionais.

As etapas de número 7 e 9 poderão ser substituidas por uma única etapa de "Levantamento do Balancete de Verificacão após 
Ajustes e Encerramento".

Com base no que foi discutido, pode-se concluir que apenas as etapas de número 1, 2 e 3 exigem uma participacão mais direta do usuário. Com a utilização do microcomputador, a terceira etapa passa a ser constituida pelo histórico de todos os fatos e transações contábeis registrados, diariamente, em um "Livro Borrador" e transcritos, periodicamente, no Livro Diário.

o "Livro Borrador" deverá ser elaborado, na segunda etapa do referido Projeto, para acompanhar o Manual de Usuários do "software" a ser desenvolvido. A partir do momento em que os dados coletados, nesse livro, derem entrada no programa pela trancrição no Diário, os demais procedimentos (etapas de número 4 a 10) poderão ser executados automaticamente, isto é, a máquina realizará quase todo o servico contábil, liberando o usuário para a análise das informações.

Assim, pressupondo o uso do microcomputador, será executado manualmente, neste Modelo, apenas o Livro Borrador que terá a funcão de "abastecer" o programa com os dados básicos das operações da empresa, como foi explicado anteriormente.

Restringindo a operacionalização manual do sistema a somente um livro, estar-se-á, consequentemente, simplificando o emprego do Método das Partidas Dobradas, pela diminuicão do volume e complexidade de seus registros.

Fica evidente, portanto, que o nivel de confiabilidade e eficiência desse Modelo será determinado, em grande parte, pela 
capacidade de seu usuário em estar atento a qualquer fato ou transacão que ocorra na empresa, registrando-o com exatidâo no "Livro Borrador".

No próximo capitulo apresenta-se um teste do Modelo proposto, mediante sua implementação em uma empresa rural, durante determinado periodo. 
3.3. O Teste do Modelo Proposto

Este capitulo tem como objetivo exemplificar o emprego do Modelo proposto, demonstrando a sua utilização por uma empresa rural, durante um determinado período contábil.

3.3.1. Breve Caracterizacão da Empresa Rural

A empresa agropecuária escolhida para a aplicação deste Modelo refere-se à Fazenda Bocaina localizada no municipio de Unai, em Minas Gerais. Essa propriedade abrange uma área de 200 ha e sua principal atividade produtiva é a pecuária de leite, desenvolvida com gado da raça Holandês Preto e Branco.

A comercialização de leite, bezerros e animais descartados constitue a mais importante fonte de renda dessa empresa. Eventualmente, pode ser realizada a recria dos machos do rebanho leiteiro, vendidos para engorda e abate ou, então, selecionados e vendidos como reprodutores.

A empresa desenvolve a cultura de milho em grãos para a alimentação dos animais, com possibilidade de venda a terceiros. Como suporte para a pecuária de leite são mantidas pastagens, com predominância do capim Andropogum.

Para o consumo da familia e empregados, a fazenda explora uma pequena criação de suinos e aves consideradas secundárias ("Outras"), por representarem reduzida parcela da lucratividade total da empresa. Entretanto, poderá ocorrer a comercializa@ão do excedente de producão dessas atividades. 
E importante esclarecer que, até o momento, a Fazenda Bocaina não desenvolve um sistema continuo de Contabilidade Gerencial levantando apenas, periodicamente, alguns dados para a elaboração de Fluxos de Caixa e para o controle técnico do rebanho leiteiro. Embora rudimentar, essa escrituracão pode ser considerada um grande avanco, no sentido de se aprimorarem os recursos administrativos da propriedade.

Não havendo informacões mais detalhadas sobre os componentes patrimoniais dessa empresa, nem registros diários de suas transacões, este "teste" considerará os dados à disposicão, complementando-os com outros elementos ficticios, na tentativa de se explorar melhor a capacidade analitica do Modelo proposto. Assim sendo, os resultados obtidos não espelham, exatamente, a realidade econômico-financeira da Fazenda Bocaina e, porisso, não deverão ser utilizados como parâmetro para a avaliacão da competência de sua gestão.

3.3.2. A Aplicacão dos Procedimentos Contábeis

Tendo em vista a grande diversidade de fatos e transações contábeis que, normalmente, ocorrem em um estabelecimento agropecuário, durante o ano agrícola, tentar-se-á simplificar este exemplo reduzindo o período contábil analisado para somente um mês (DEZEMBRO/1990), com significativa diminuicão do volume de registros.

Além disso, como a principal intencão é demonstrar os procedimentos mais relevantes, que diferenciam a metodologia 
desenvolvida daquelas empregadas pelos modelos analisados, seráo contabilizadas somente as operacões mais representativas para a formação do resultado econômico-financeiro do periodo.

A utilizacão dos dados da Fazenda Bocaina pelo Modelo proposto é apresentada, a seguir, conforme o roteiro dos procedimentos contábeis organizado no item 3.211.

1. Levantamento do Inventário

\section{Estoques}

A Tabela 16 representa uma ficha para Inventário Periódico, descrevendo os Estoque Iniciais de uma amostra dos bens submetidos à esse tipo de controle e as respectivas movimentacões de entrada e saida, ocorridas durante o periodo.

As Tabelas 17, 18 e 19 correspondem às Fichas de Estoque de alguns itens sob Inventário Permanente, registrando os Estoques Iniciais, entradas e saidas e Estoques Finais. 
Tabela 16. Inventério Peribdico

EMPRESA RURRAL: FAIENDA GOCAIMA

DATA: $01 / 12 / 90$

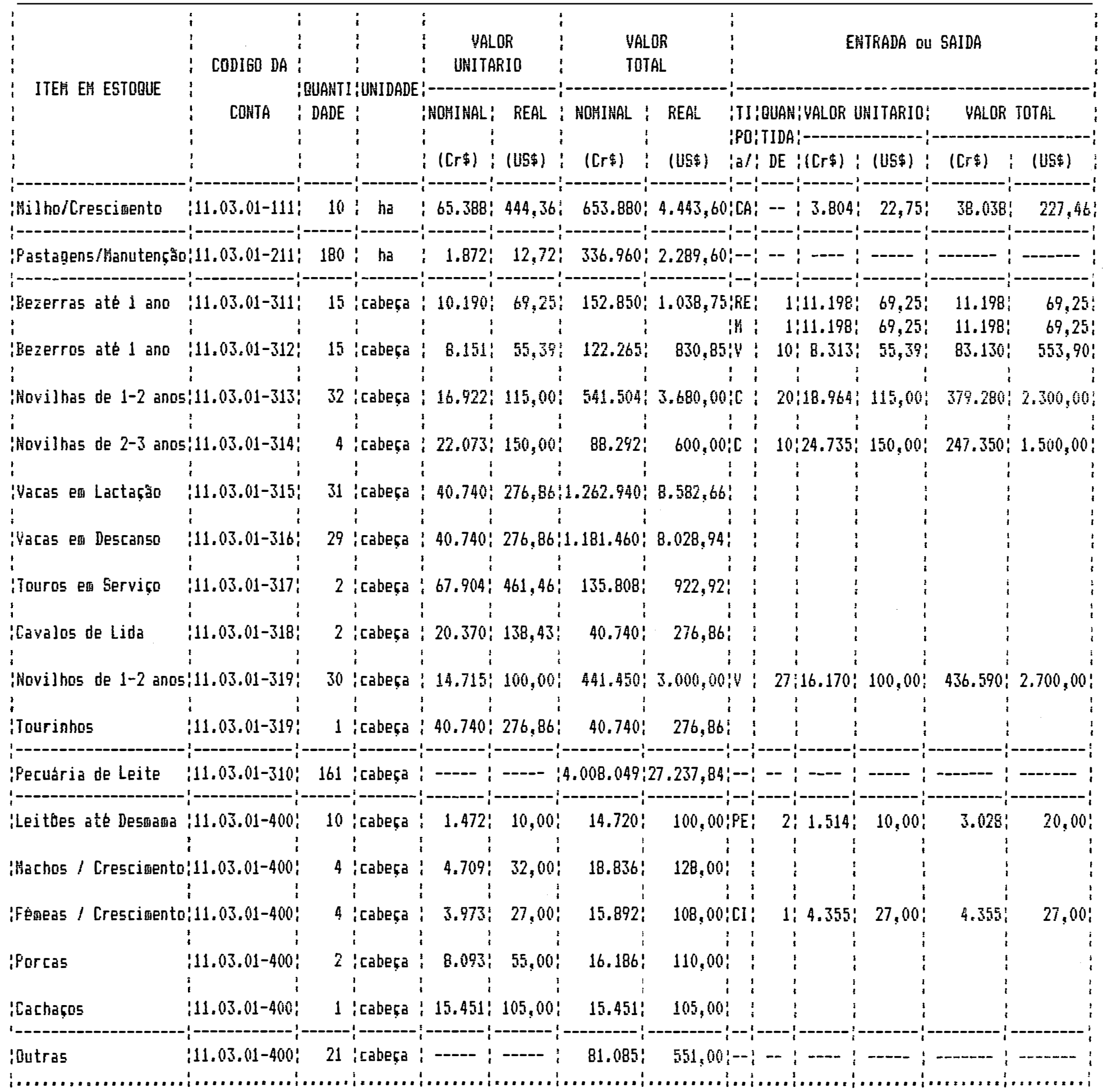

(continua) 
Tabela 16. Inventário Periódico icontinuaçžo\}

EMFRESA RUURAL: FAIENDA EOCAINA

DATA: $01 / 12 / 90$

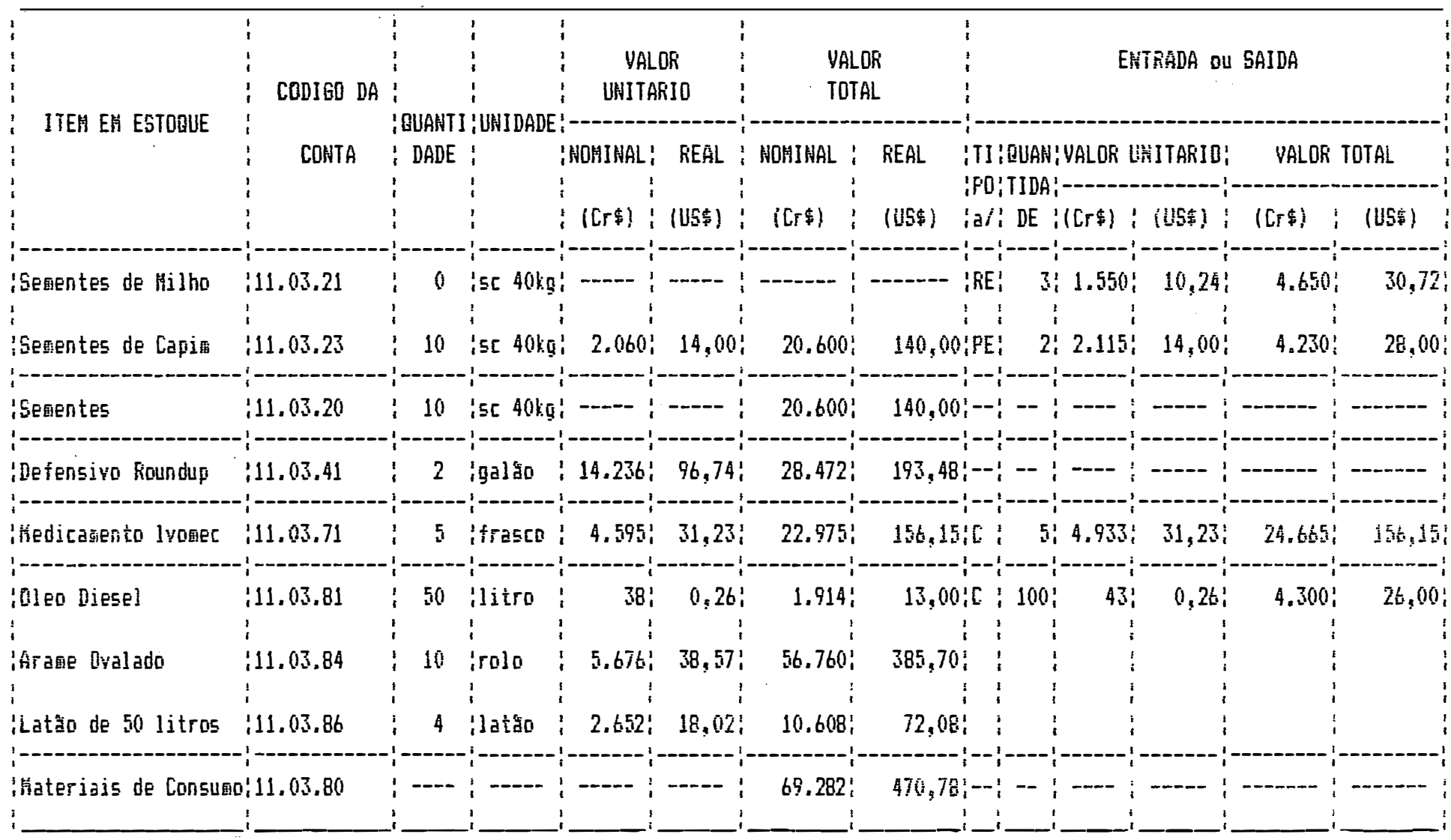

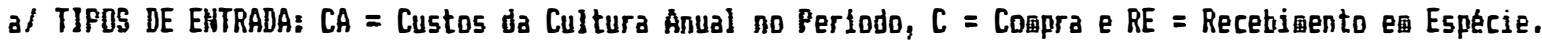

TIPOS DE SAIDA : $V=$ Venda, $C I=$ Consumo Interno, $P E=$ Fagamento Especie, $U=$ Uso Interno, $F=$ Perda e $H=$ Horte. 
Tabela 17. Ficha de Estoque

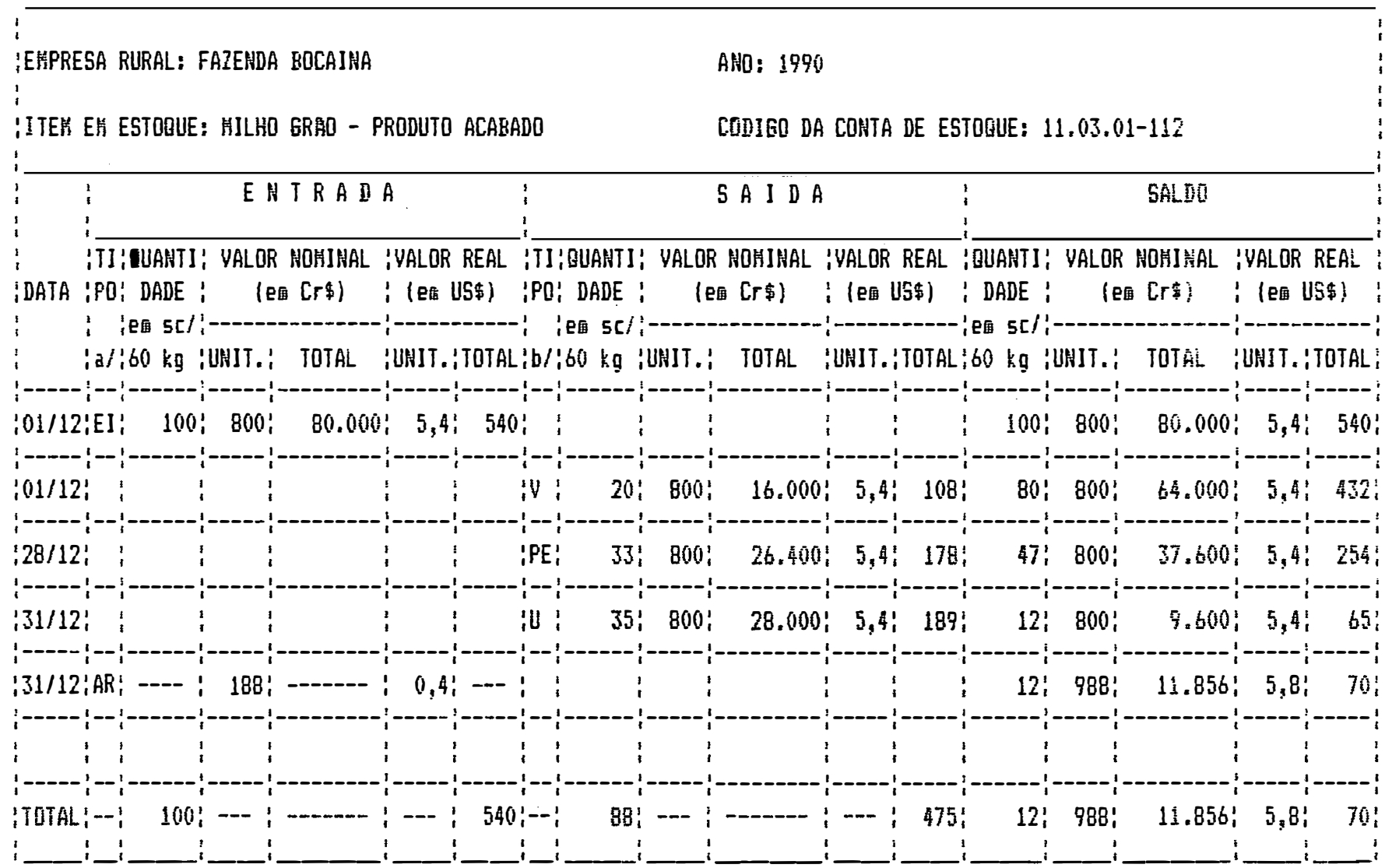

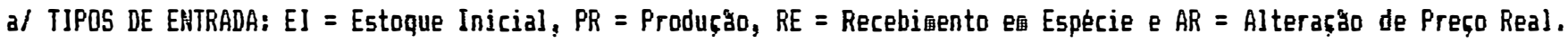

b/ TIPOS DE SAIDA: $V=$ Venda, $C I=$ Consumo Interno, PE = Pagamento e面 Especie, $U=$ Uso Interno e $P=$ Ferda. 
Tabela 18. Fichá de Estoque

EAFFRESA RURAL: FAZENDA EOCAINA

ITEH EH ESTOQUE: FERTILIZANTE - APK (04-14-(18)
AND: 1990

CODIGO DA CONTA DE ESTOQUE: 11.03 .31

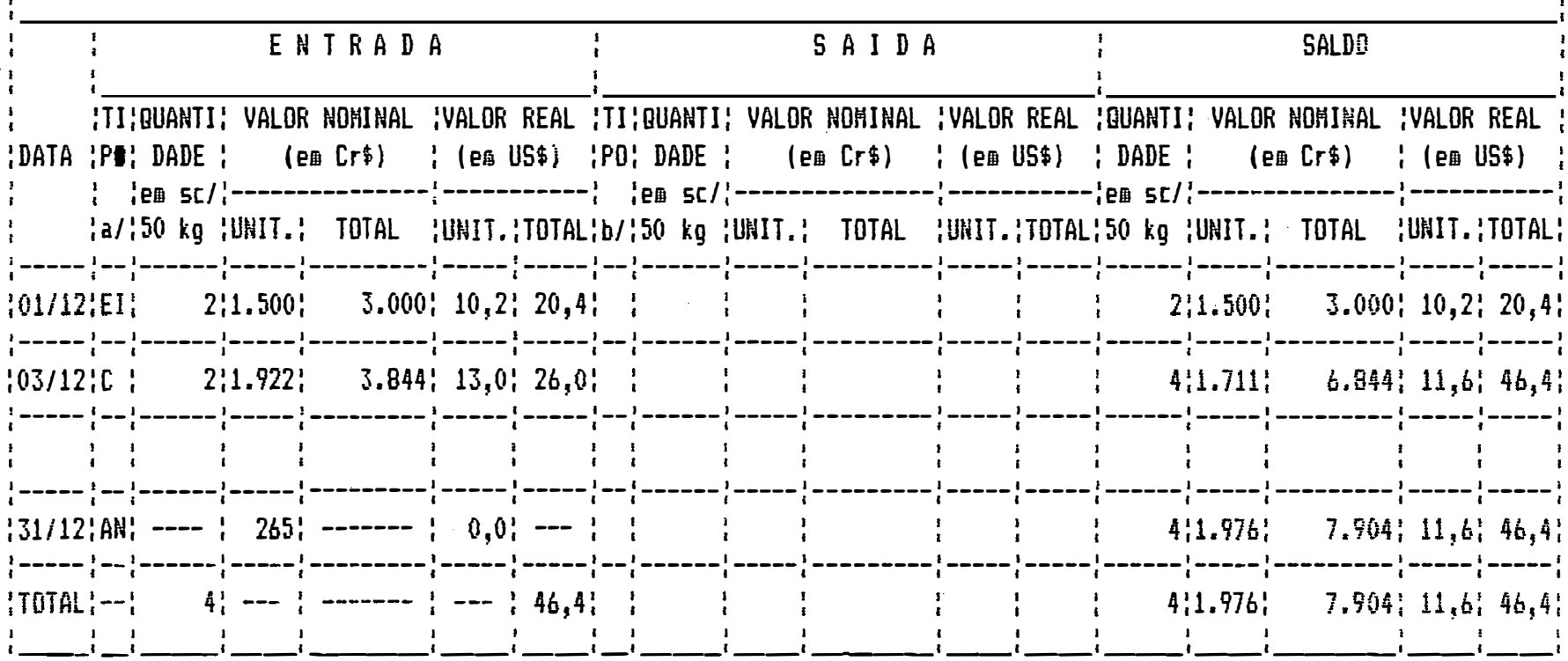

Tabela 19. Ficha de Estoque

EMPRESA RURAL: FAIENDA EOCAINA

ITEH EH ESTOQUE: FARELO DE SOJA
AND: 1990

CODIGO DA CONTA DE ESTOQUE: 11.03 .61

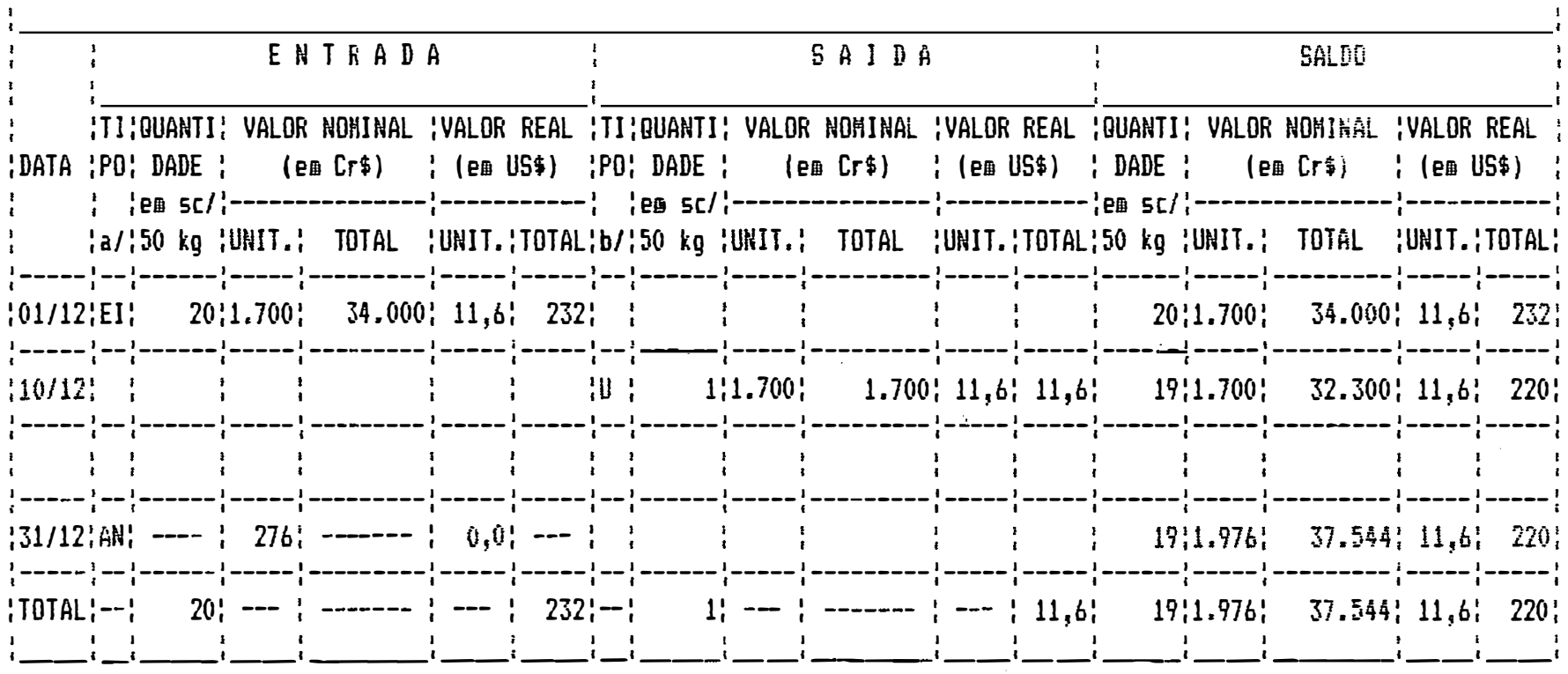

a) TIPOS DE ENTRADA: EI = Estoque Inicial, PR = Produçăo, $C=$ Compra, RE = Receb. Espécie e AP = Alter. Preço Notoinal.

b/ TIPOS DE SAIDA: $V=$ Venda, $C I=$ Consumo Interno, PE = Pagagento el Especie, $U=$ Uso Interno e P $=$ Perda. 
Através do software "DEPRECIA", foram elaboradas as Tabelas 20, 21 e 22 que descrevem apenas os componentes mais representativos do Imobilizado da Fazenda. Cabe ressaltar que, pela ausência de dados confiáveis sobre a aquisicão desses bens, os mesmos foram avaliados pelo preco corrente de mercado, em 01/12/90. Posteriormente, foram obtidas as Tabelas 23, 24 e 25 que apresentam informações relativas à depreciacão de cada item, com base na sua vida útil futura, a partir da data de levantamento do inventário.

Balanco Patrimonial

Após o levantamento dos demais componentes patrimoniais da empresa, é concluida a primeira etapa do processo de elaboração dos relatórios contábeis, com a apresentacão do Balanco Patrimonial Inicial da Fazenda Bocaina (Tabela 26).

2. O Elenco de Contas da Fazenda Bocaina

As Tabelas 27 e 28, a seguir, representam adaptacões do Sub-Elenco de Contas das Atividades Produtivas e Elenco de Contas Simplificado (item 3.2.5.), às caracteristicas da empresa rural em questão. Trata-se de simples ilustracão do que seria o Elenco de Contas Completo, incluindo desdobramentos do 5o. ao 7o. graus onde se empregam as extensões de três digitos, mencionadas anteriormente. Vale lembrar que, neste exemplo, serão utilizadas apenas as contas mais relevantes para a diferenciacão do Modelo proposto. 
Tabela 20. Controle de Ativo lrobilizado - Relaçáco de Dados

CONTROLE DE VEICULOS, HAQUINARIA, EQUIPAHENTOS E IHFLEHENTOS

RELAÇAD DE DADOS

Data de Emis5äo: 01/12/90

Unidade Monetária: Crta e US\$

Categoria: haquinaria Tipo: tratoR Codigo: 22

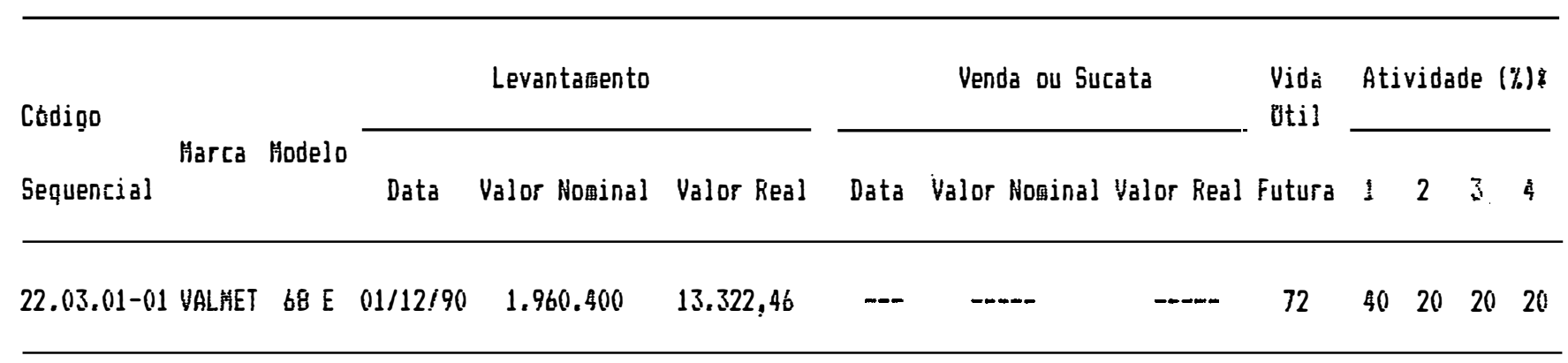

\begin{tabular}{|c|c|c|c|c|c|c|c|c|c|c|c|c|c|c|c|c|}
\hline \multirow{3}{*}{$\begin{array}{l}\text { Codigo } \\
\text { Sequencial }\end{array}$} & \multirow{3}{*}{ Marca } & \multirow{3}{*}{ Hodelo } & \multicolumn{3}{|c|}{ Categoria: HARUINARIA } & \multicolumn{3}{|c|}{ Tipo: } & \multicolumn{8}{|c|}{ Codigo: 23} \\
\hline & & & \multicolumn{3}{|c|}{ Levantamento } & \multicolumn{5}{|c|}{ Venda ou Sucata } & \multirow{2}{*}{$\begin{array}{l}\text { Vida } \\
\text { Dtil } \\
\text { Futura }\end{array}$} & \multicolumn{5}{|c|}{ Atividade $\{\%$} \\
\hline & & & Data & Valor Notinal & Valor Real & Data & Valor & Noginal & Valor & Real & & $\mathfrak{i}$ & 2 & 3 & 4 & 4 \\
\hline $23.03 .01-01$ & $\begin{array}{l}\text { HOTOR } \\
\text { DIESEL }\end{array}$ & $7,5 \mathrm{HP}$ & $01 / 12 / 90$ & $136.500,00$ & 927,62 & --- & & $\cdots$ & & ---- & 60 & 0 & 0 & 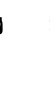 & 80 & 20 \\
\hline $23.04 .01-01$ & $\begin{array}{l}\text { MOTOR } \\
\text { TRIFAS }\end{array}$ & $\begin{array}{l}7,5 \mathrm{HP} \\
\mathrm{ICO}\end{array}$ & $01 / 12190$ & $20.000,00$ & 135,92 & -- & & $\cdots$ & & $\cdots$ & 60 & $\bullet$ & 0 & 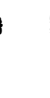 & & 20 \\
\hline $23.05 .01-01$ & $\begin{array}{l}\text { TRITUR } \\
\text { NOGUEI }\end{array}$ & $\begin{array}{l}A A D O R \\
R A\end{array}$ & $01 / 12 / 90$ & $30.733,00$ & 208,85 & -- & & $-\cdots$ & & --.- & 60 & 0 & $\theta$ & 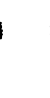 & & 20 \\
\hline
\end{tabular}

1: HILHO 2: FASTAgE 3: FECUARIA DE LEITE 4: DLITRAS 
Tabela 21. Controle de Ativo Igotilizado - Relaşado de Dados

CONTROLE DE VEICULOS, HAQUIAARIA, EQUIFAMENTOS E IMFLEHENTOS

RELACFE DE DADOS

Data de Erisissão: 011/12/90

Unidade Honetária: Cr\$ e US\$

Categoria: Equifamentos E IMFLEMERTOS Tipo: Agricolas Código: 31

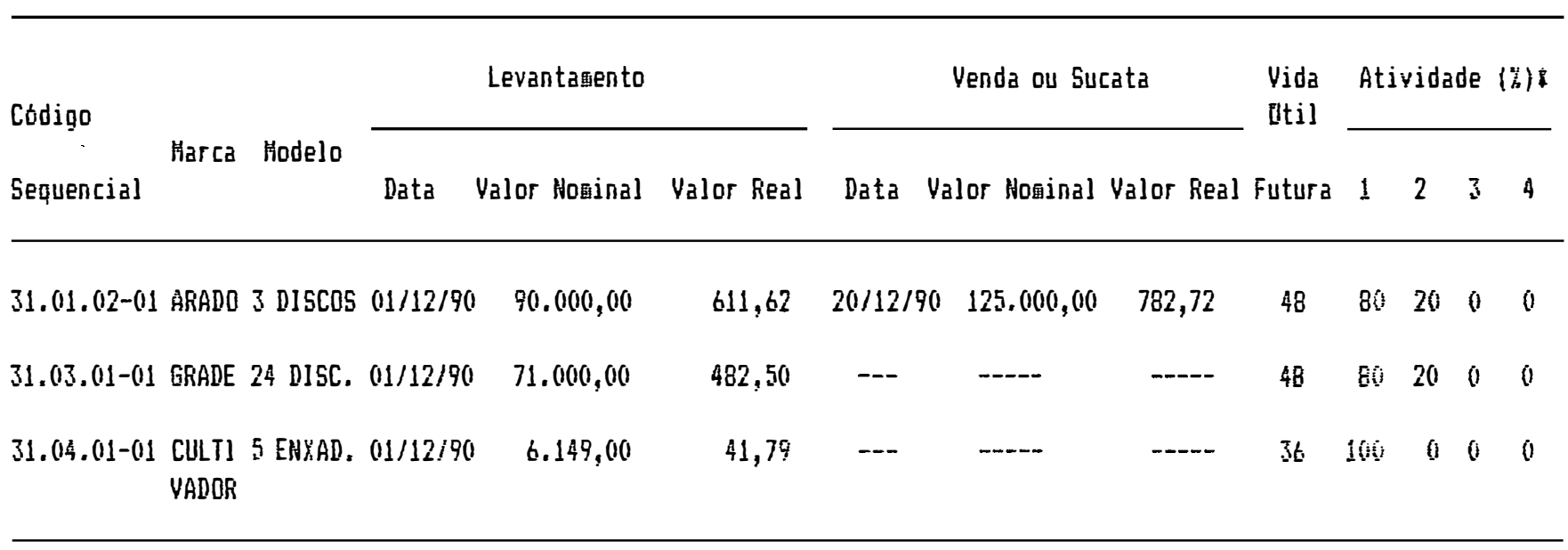

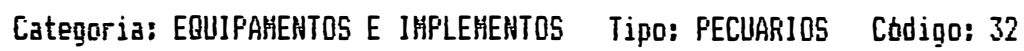

\begin{tabular}{|c|c|c|c|c|c|c|c|c|c|c|c|c|c|}
\hline \multirow{2}{*}{$\begin{array}{l}\text { Códino } \\
\text { Seguencial }\end{array}$} & \multirow{2}{*}{ Harca Hodelo } & \multicolumn{3}{|c|}{ Levantamento } & \multicolumn{4}{|c|}{ Venda ou Sucata } & \multirow{2}{*}{$\begin{array}{l}\text { Vida } \\
\text { Etil } \\
\text { Futura }\end{array}$} & \multicolumn{4}{|c|}{ Atividade $(\%)$} \\
\hline & & Data & Valor Ho畐inal & Valor fieal & Data & Valor Hoginal & Valor & Real & & 1 & 2 & 3 & 4 \\
\hline $32.07 .01-01$ & $\begin{array}{l}\text { DRDEEHIADEIRA } \\
\text { MECAHICA }\end{array}$ & $01 / 12 / 90$ & $805,000,00$ & $2.752,29$ & -- & $m$ & & $\cdots$ & 60 & 0 & 0 & 100 & 0 \\
\hline $32.03 .01-01$ & $\begin{array}{l}\text { RESFRIADOR } \\
\text { DE LEITE }\end{array}$ & $01 / 12 / 90$ & $381.0000,00$ & $2.589,19$ & -- & $-\cdots$ & & $\cdots$ & 36 & 0 & 0 & 100 & 0 \\
\hline
\end{tabular}

1: HILHO 2: PASTAGEH 3: PECUARIA DE LEITE 4: OUTRAS 


\section{COATROLE DE CULTURAS PEREBES}

RELACGO DE DADOS

Data de E西is5so: 01/12/90

Unidade Monetária: Cr\% e US\$

\begin{tabular}{|c|c|c|c|c|c|c|c|c|c|c|c|c|c|c|c|}
\hline \multirow{3}{*}{$\begin{array}{l}\text { Código } \\
\text { Sequencial }\end{array}$} & \multirow{3}{*}{$\begin{array}{c}\text { Variedade } \\
\text { ou } \\
\text { Cultivar }\end{array}$} & \multicolumn{3}{|c|}{ Categoria: PASTAgEnS } & \multicolumn{3}{|c|}{ Tipo: ARTIFICIAIS } & \multicolumn{4}{|c|}{ Ctớigo: 12} & & & & \\
\hline & & \multicolumn{3}{|c|}{ Levantamento } & & \multicolumn{5}{|c|}{ REFor Giè } & \multirow{2}{*}{$\begin{array}{l}\text { Vida } \\
\text { [ltil } \\
\text { Futura }\end{array}$} & \multicolumn{4}{|c|}{ Atividade ( $/$ ) } \\
\hline & & Data & Valor Hominal & Valor & Keal & Data & Yalor & Howinal & Valor & Keal & & 1 & 2 & 3 & 4 \\
\hline $12-01$ & Andropoguri & $01 / 12$ & $903.900 .000,000$ & 26.50 & 3,57 & -- & & ---- & & --- & 36 & 0 & 100 & 0 & 0 \\
\hline
\end{tabular}

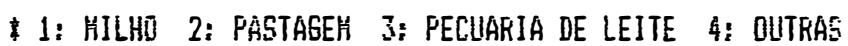


Tabela 23. Controle de Ativo I robilizado - Depreciaçăo por Item

CONTROLE DE VEICULOS, HAQUINARIA, EQUIFAMENTOS E ImFLEHENTOS

DEFRECIAÇAO FOR ITEH

Data de E面i5580:01/01/91

Ferlodo Analisado: 01/12/90 a 01/01/91

Unidade Honetária: US\$

Categoria: maguinaRia Tipo: trator Código: 22

\begin{tabular}{|c|c|c|c|c|c|c|c|c|c|c|c|c|c|c|c|}
\hline \multirow{3}{*}{$\begin{array}{l}\text { Código } \\
\text { Sequencial }\end{array}$} & \multirow{3}{*}{$\begin{array}{l}\text { Idade } \\
\text { na Data } \\
\text { de } \\
\text { Venda } \\
\text { (meses) }\end{array}$} & \multirow{3}{*}{$\begin{array}{l}\text { Idade } \\
\text { no Final } \\
\text { do } \\
\text { Período } \\
\text { (meses) }\end{array}$} & \multicolumn{4}{|c|}{ Depreciaçăo Hensa] } & \multirow{3}{*}{ Total } & \multicolumn{4}{|c|}{ Depreciaça do Feríodo } & \multirow{3}{*}{$\begin{array}{c}\text { Depreciaçáa } \\
\text { Acumulada } \\
\text { Total }\end{array}$} & \multirow{3}{*}{$\begin{array}{c}\text { Valor } \\
\text { Contábil } \\
\text { Real na } \\
\text { Data da } \\
\text { Venda }\end{array}$} & \multirow{3}{*}{$\begin{array}{l}\text { Valor } \\
\text { Contábil } \\
\text { Real no } \\
\text { Final do } \\
\text { Ferlodo }\end{array}$} & \multirow{3}{*}{$\begin{array}{l}\text { Ganholt } \\
\text { ou } \\
\text { Ferdal-l } \\
\text { Real } \\
\text { na Venda }\end{array}$} \\
\hline & & & \multicolumn{4}{|c|}{ Atividade } & & \multicolumn{4}{|c|}{ Atividade } & & & & \\
\hline & & & 1 & 2 & 3 & 4 & & 1 & 2 & 3 & 4 & & & & \\
\hline $22.03 .01-01$ & $m$ & 1 & 74,01 & 37,01 & 37,01 & 37,01 & 185,04 & 74,01 & 37,01 & 37,01 & 137,01 & 185,04 & $-\cdots$ & $13,137,47$ & -- \\
\hline
\end{tabular}

Categoria: maQUinaRIa Tipo: hotoR Cádigo: 23

\begin{tabular}{|c|c|c|c|c|c|c|c|c|c|c|c|c|c|c|c|}
\hline \multirow{3}{*}{$\begin{array}{l}\text { Código } \\
\text { Sequencial }\end{array}$} & \multirow{3}{*}{$\begin{array}{l}\text { Idade } \\
\text { na Data } \\
\text { de } \\
\text { Venda } \\
\text { (iveses) }\end{array}$} & \multirow{3}{*}{$\begin{array}{l}\text { Idade } \\
\text { no Final } \\
\text { do } \\
\text { Perlodo } \\
\text { (meses) }\end{array}$} & \multicolumn{4}{|c|}{ Depreciaçăo Hensa] } & \multirow{3}{*}{ Total } & \multicolumn{4}{|c|}{ Depreciaço do Ferlodo } & \multirow{3}{*}{$\begin{array}{c}\text { Depreciaçáno } \\
\text { Acu町ada } \\
\text { Total }\end{array}$} & \multirow{3}{*}{$\begin{array}{c}\text { Valor } \\
\text { Contábil } \\
\text { Real na } \\
\text { Data da } \\
\text { Venda }\end{array}$} & \multirow{3}{*}{$\begin{array}{l}\text { Valor } \\
\text { Contábil } \\
\text { Reai no } \\
\text { Final do } \\
\text { Feríodo }\end{array}$} & \multirow{3}{*}{$\begin{array}{l}\text { Ganholt) } \\
\text { ou } \\
\text { Ferdal-1 } \\
\text { Real } \\
\text { na Venda }\end{array}$} \\
\hline & & & \multicolumn{4}{|c|}{ Atividade } & & \multicolumn{4}{|c|}{ Atividade } & & & & \\
\hline & & & 1 & 2 & 3 & 4 & & 1 & 2 & 3 & 4 & & & & \\
\hline $23.03 .01-01$ & --- & 1 & 0 & 0 & 12,37 & 3,09 & 15,46 & 0 & 0 & 12,37 & 3,09 & 15,46 & -- & 912,16 & -- \\
\hline $23.04 .01-01$ & --- & 1 & 0 & 0 & 1,82 & 0,45 & 2,27 & 0 & 0 & 1,82 & 0,45 & 2,27 & --- & 133,65 & --- \\
\hline $23.015 .01-01$ & $-\cdots$ & 1 & 0 & 0 & 2,78 & 0,70 & 3,46 & 0 & 0 & 2,78 & 0,70 & 3,48 & -- & 205,37 & $\cdots$ \\
\hline
\end{tabular}

1: HILHO 2: FAstagef 3: FECUARIA DE LEITE 4: OUTRAS 
Tabela 24. Controle de Ativo Imobilizado - Depreciaçáa por Iter

CONTROLE DE VEICULOS, HAQUINARIA, EQUIPAHENTTOS E IHPLEHENTOS

DEPRECIAÇAO POR ITEH

Data de E西is5áo: 01/01/91

Periodo Analisado: 01/12/90 a 01/01/91

Unidade Honetaria: US\$

Categoria: EgUIPAHENTOS E IHPLEMENTOS Tipo: AgRICOLAS Código: 31

\begin{tabular}{|c|c|c|c|c|c|c|c|c|c|c|c|c|c|c|c|}
\hline \multirow{3}{*}{$\begin{array}{l}\text { Códigoo } \\
\text { Sequencial }\end{array}$} & \multirow{3}{*}{$\begin{array}{l}\text { Idade } \\
\text { na Data } \\
\text { de } \\
\text { Venda } \\
\text { (ríeses) }\end{array}$} & \multirow{3}{*}{$\begin{array}{l}\text { Idade } \\
\text { no Final } \\
\text { do } \\
\text { Perlodo } \\
\text { (meses) }\end{array}$} & \multicolumn{4}{|c|}{ Deprecią̧áo hensa] } & \multirow{3}{*}{ Total } & \multicolumn{4}{|c|}{ Depreciaşáco do Período } & \multirow{3}{*}{$\begin{array}{c}\text { Depreciaçáo } \\
\text { Acurulada } \\
\text { Total }\end{array}$} & \multirow{3}{*}{$\begin{array}{c}\text { Valor } \\
\text { Contábil } \\
\text { Real na } \\
\text { Data da } \\
\text { Venda }\end{array}$} & \multirow{3}{*}{$\begin{array}{c}\text { Valor } \\
\text { Contabil } \\
\text { Real no } \\
\text { Final do } \\
\text { Perlodo }\end{array}$} & \multirow{3}{*}{$\begin{array}{l}\text { Ganholt) } \\
\text { ou } \\
\text { Perda(-) } \\
\text { Real } \\
\text { na Venúa }\end{array}$} \\
\hline & & & \multicolumn{4}{|c|}{ Atividade } & & \multicolumn{4}{|c|}{ Atividade } & & & & \\
\hline & & & 1 & 2 & 3 & 4 & & 1 & 2 & 3 & 4 & & & & \\
\hline $31.01 .02-01$ & $\ll 1$ & -- & $\cdots$ & $-\cdots$ & --- & --- & ---- & --- & -- & $\cdots$ & -- & ---- & 611,62 & ---- & 171,10 \\
\hline $31.03 .01-01$ & $\cdots$ & 1 & 8,04 & 2,01 & 0 & 0 & 10,05 & 8,04 & 2,01 & 0 & 0 & 10,05 & $\cdots$ & $572,4 t^{5}$ & ----- \\
\hline $31.04 .01-01$ & --- & 1 & 1,16 & 0 & 0 & 0 & 1,16 & 1,16 & 0 & 0 & 0 & 1,16 & $\cdots$ & 40,63 & --.--das" \\
\hline
\end{tabular}

Categoria: Equipahentos E IMPLEHENTOS Tipo: PECUARIOS Código: 32

\begin{tabular}{|c|c|c|c|c|c|c|c|c|c|c|c|c|c|c|c|}
\hline \multirow{3}{*}{$\begin{array}{l}\text { Código } \\
\text { Sequencial }\end{array}$} & \multirow{3}{*}{$\begin{array}{l}\text { Jdade } \\
\text { na Data } \\
\text { de } \\
\text { Venda } \\
\text { (ríeses) }\end{array}$} & \multirow{3}{*}{$\begin{array}{l}\text { Idade } \\
\text { no Final } \\
\text { do } \\
\text { Períoda } \\
\text { (aeses) }\end{array}$} & \multicolumn{4}{|c|}{ Depreciaçáa Hensa] } & \multirow{3}{*}{ Total } & \multicolumn{4}{|c|}{ Depreciaç̧o do Período } & \multirow{3}{*}{$\begin{array}{l}\text { Depreciaçáo } \\
\text { Acurulada } \\
\text { Total }\end{array}$} & \multirow{3}{*}{$\begin{array}{c}\text { Valor } \\
\text { Contábil } \\
\text { Real na } \\
\text { Data da } \\
\text { Venda }\end{array}$} & \multirow{3}{*}{$\begin{array}{l}\text { Valor } \\
\text { Contábil } \\
\text { Fea] no } \\
\text { Final do } \\
\text { Perlodo }\end{array}$} & \multirow{3}{*}{$\begin{array}{l}\text { Ganholt) } \\
\text { Ou } \\
\text { Perdal-) } \\
\text { Real } \\
\text { na Venda }\end{array}$} \\
\hline & & & \multicolumn{4}{|c|}{ Atividade } & & \multicolumn{4}{|c|}{ Atividade } & & & & \\
\hline & & & 1 & 2 & 3 & 4 & & 1 & 2 & 3 & 4 & & & & \\
\hline $32.02 .01-01$ & -- & 1 & 0 & 0 & 0 & 45,87 & 45,87 & 0 & 0 & 0 & 45,87 & 45,87 & --- & $2.706,42$ & -- \\
\hline $32.03 .01-01$ & -- & 1 & 0 & 0 & 0 & 71,92 & 71,92 & 0 & 0 & 0 & 71,92 & 71,92 & -- & $2.517,27$ & --- \\
\hline
\end{tabular}

1: hILHO 2: PASTAGeh 3: PECUARIA DE LEITE 4: OUITRAs 
Tabela 25. Controle de Ativo Igobilizado - Depreciaçáa por Ite日

CONTROLE DE CILLTURAS FERERES

DEPRECIAÇRO POR ITEH

Data de E田issáo: 01/01/91

Perlodo Analisado: 01/12/90 a 01/01/91

Unidade Monetária: U5

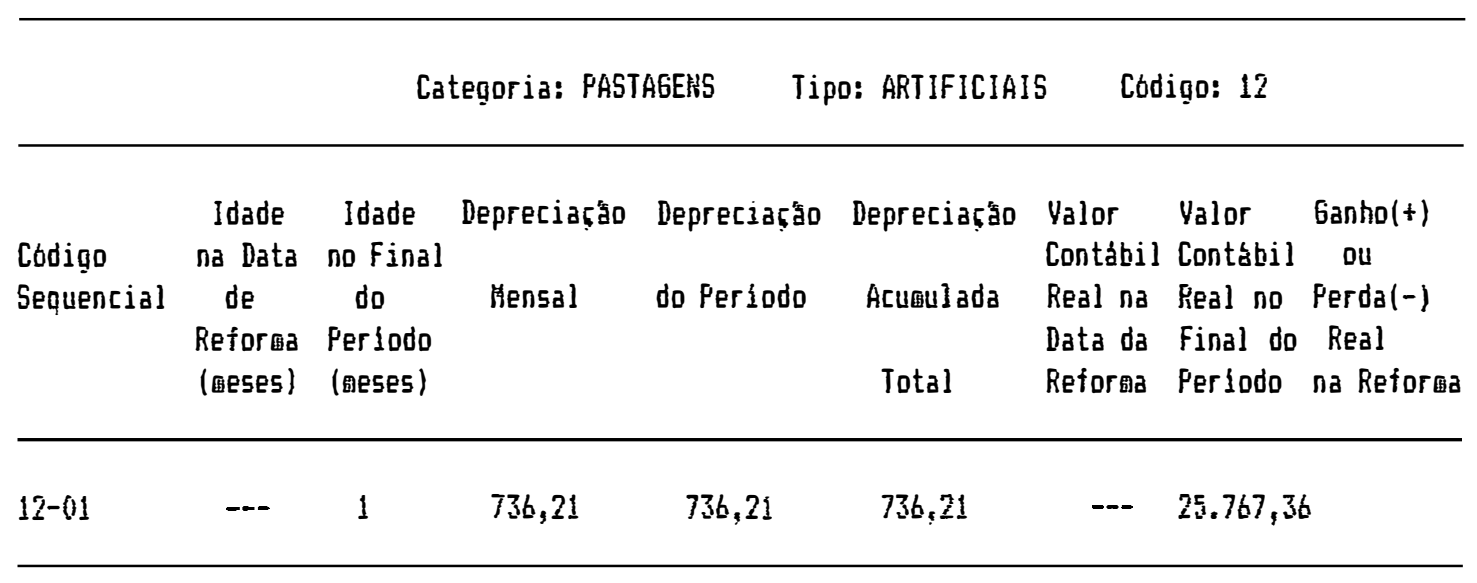


Tabela 26. Falanço Fatrimonial

EMFFESA RURAL : FAZENDA BOCAINA

DATA: $01 / 12 / 90$

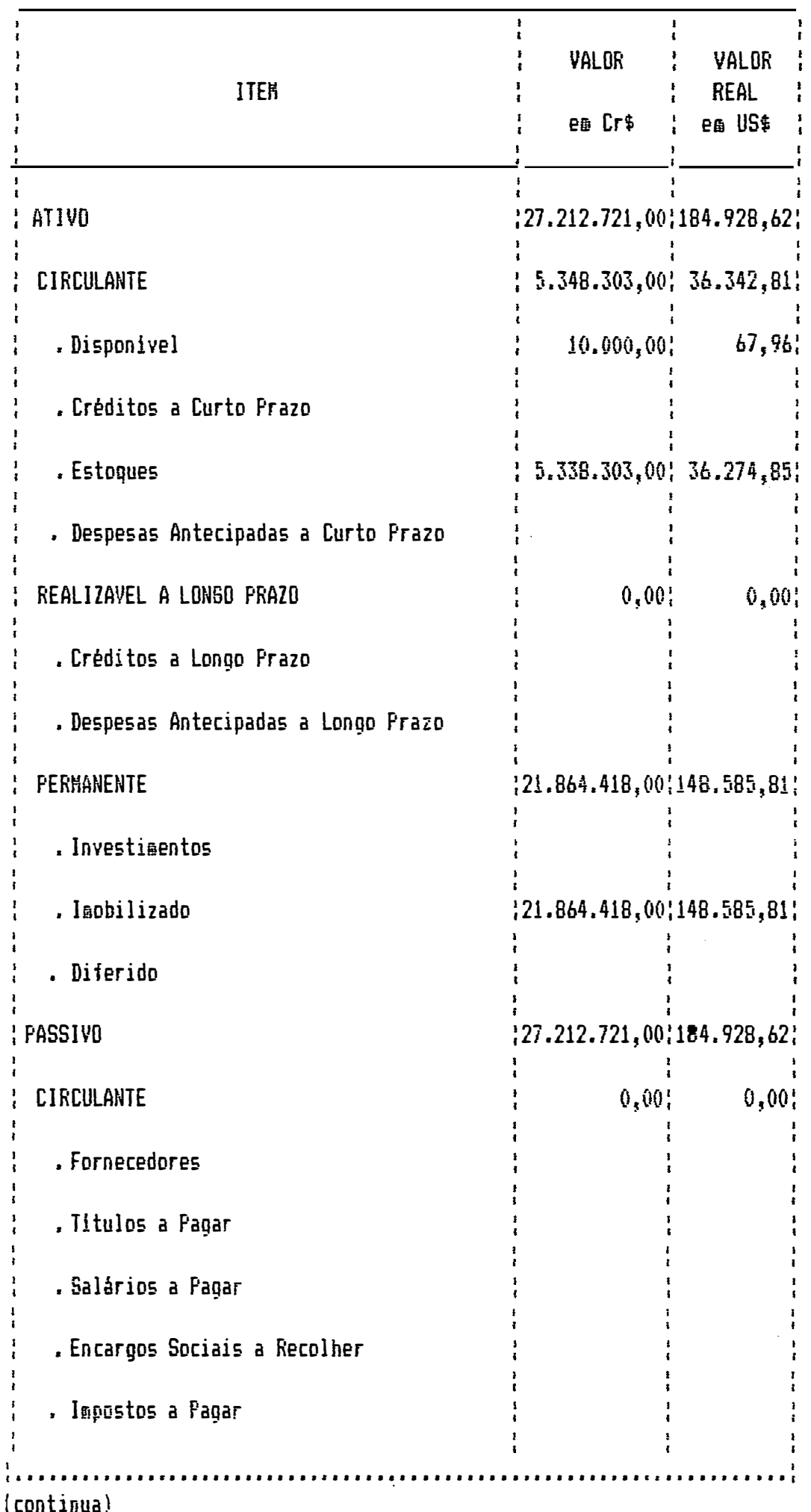


Tabela 26. Balanço Patrimonial (coritinuaşol

EMFFESA FILIFAL : FAIEHDA BOCAIHA

DATA: $01 / 12 / 90$

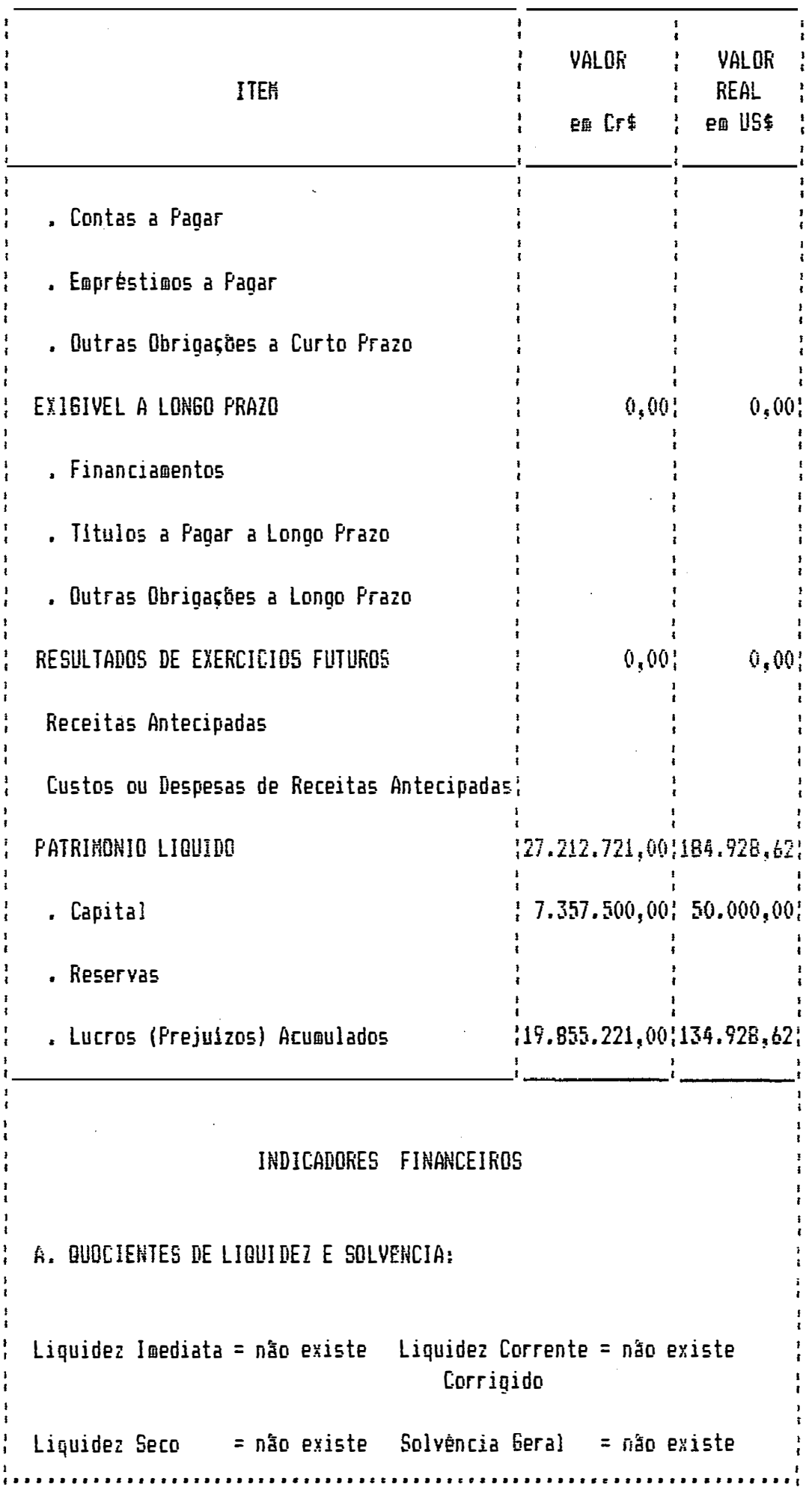

(continua) 
Tabela 26. Balanço Patringnial icontinuą̧ă

EMFFESA RURAL : FAIENDA BOCAINA

DATA: $01 / 12 / 90$

E. QULOCIENTES DE ENDIVIDÁHENTO:

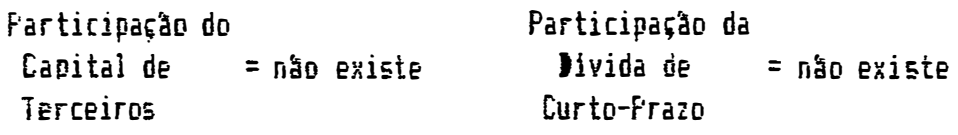

Alavanca Financeira $=0,00$

Como é possível observar no seu BP, em 01/12/90 a Fazenda Bocaina não apresentava obrigações para com terceiros, financiando suas atividades através de capital próprio, ou seja, de investimentos feitos pelos proprietários no capital da empresa e de lucros resultantes de suas operacões.

Uma vez que não havia compromissos a serem saldados (Passivo Exigivel $=0$ ), não existiam valores para os quocientes de liquidez, solvência e endividamento. Em contrapartida, a Alavanca Financeira da empresa era nula, indicando uma capacidade integral de contrair dívidas, empréstimos e financiamentos. 
Tabela 27. Sub-Elenco de Contas das Atividades Produtivas EMPRESA RURAL: EAZENDA BOCAINA

GRAU CODIGO A- EXTENSAO

NOME DA CONTA DESTACAR

$\begin{array}{lcc}5 & 00.00 \cdot 00-100 & \text { Culturas Anuais } \\ 6 & 00.00 \cdot 00-110 & \text { Milho Grão } \\ 7 & 00.00 .00-111 & \text { Em Crescimento } \\ 7 & 00.00 .00-112 & \text { Produto Acabado } \\ 5 & 00.00 .00-200 & \text { Culturas Perenes } \\ 6 & 00.00 .00-210 & \text { Pastagem Andropogum } \\ 7 & 00.00 .00-211 & \text { Em Manutenção } \\ 5 & 00.00 \cdot 00-300 & \text { Animais e Produtos Animais } \\ 6 & 00.00 .00-310 & \text { Pecuária de Leite } \\ 5 & 00.00 \cdot 00-400 & \text { Outras Atividades Agropecuárias } \\ 7 & 00.00 .00-999 & \text { Centro de Resultados Indiretos }\end{array}$


Tabela 28. Elenco de Contas Completo

EMPRESA RURAL: FAZENDA BOCAINA

\section{GRAU CODIGO}

11

211

$3 \quad 11.01$

$4 \quad 11.01 .01$

$4 \quad 11.01 .02$

$511.01 .02-001$

$3 \quad 11.02$

411.02 .01

5

4

5

4

5

4

5

3

4

5

6
11.02.01-001 a 099

11.02 .02

$11.02 .02-001$ a 099

11.02 .03

$11.02 .03-001$ a 099

11.02 .04

$11.02 .04-001$ a 099

11.03

11.03 .01

11.03.01-100

11.03.01-110

11.03.01-111

11.03.01-112

11.03.01-200

$11.03 .01-210$

$11.03 .01-211$

11.03.01-300

$11.03 .01-310$

$11.03 .01-311$

$11.03 .01-312$

$11.03 .01-313$

$11.03 .01-314$

$11.03 .01-315$

$11.03 .01-316$

$11.03 .01-317$

$11.03 .01-318$

11.03.01-319

$11.03 .01-400$

$11.03 .01-500$

$11.03 .01-510$

11.03.01-511

11.03.01-600

11.03 .20

11.03 .21

11.03 .22

11.03 .23

11.03 .30

11.03 .31

$11.03 .31-100$

NOME DA CONTA

\author{
ATIVO \\ CIRCULANTE \\ DISPONIVEL \\ Caixa \\ Bancos - Conta Corrente \\ Banco do Brasil
}

CREDITOS A CURTO PRAZO

Titulos a Receber a Curto-Prazo

A Destacar

Contas a Receber a Curto-Prazo

A Destacar

Adiantamentos e Empréstimos

A Destacar

Aplicacões Financeiras de Curto-Prazo

A Destacar

\section{ESTOQUES}

Estoques da Produção

Culturas Anuais

Milho Grão

Em Crescimento

Produto Acabado

Culturas Perenes

Pastagens Andropogum

Em Manutencão

Animais

Pecuária de Leite

Bezerras até 1 ano

Bezerros até 1 ano

Novilhas 1-2 anos

Novilhas 2-3 anos

Vacas em Lactaça

Vacas em Descanso

Touros em Servico

Cavalos de Lida

Outras Categorias

Outros Estoques de Ativ. Agropecuárias

Produtos Animais

Pecuária de Leite

Esterco

Outros Estoques de Produtos Animais

Estoques de Sementes e Mudas

Milho Hibrido

Milho Comum

Andropogum

Estoques de Fertilizantes e Corretivos

NPK (04-14-08)

Culturas Anuais 
Tabela 28. Elenco de Contas Completo (continuacão)

EMPRESA RURAL: FAZENDA BOCAINA

GRAU CODIGO

$\begin{array}{ll}7 & 11.03 .31-110 \\ 6 & 11.03 .31-200 \\ 7 & 11.03 .31-210 \\ 6 & 11.03 .31-400 \\ 7 & 11.03 .31-999 \\ 4 & 11.03 .40 \\ 5 & 11.03 .41 \\ 6 & 11.03 .41-100 \\ 7 & 11.03 .41-110 \\ 6 & 11.03 .41-200 \\ 7 & 11.03 .41-210 \\ 6 & 11.03 .41-400 \\ 7 & 11.03 .41-999 \\ 4 & 11.03 .50 \\ 4 & 11.03 .60 \\ 5 & 11.03 .61 \\ 6 & 11.03 .61-310 \\ 6 & 11.03 .61-400 \\ 7 & 11.03 .61-999 \\ 4 & 11.03 .70 \\ 5 & 11.03 .71 \\ 7 & 11.03 .71-999 \\ 4 & 11.03 .80 \\ 5 & 11.03 .81 \\ 7 & 11.03 .81-999 \\ 5 & 11.03 .82 \\ 7 & 11.03 .82-999 \\ 5 & 11.03 .83 \\ 7 & 11.03 .83-999 \\ 5 & 11.03 .84 \\ 7 & 11.03 .84-999 \\ 5 & 11.03 .85 \\ 7 & 11.03 .85-999 \\ 5 & 11.03 .86 \\ 7 & 11.03 .86-999 \\ 5 & 11.03 .87 \\ 7 & 11.03 .87-999 \\ 3 & 11.04 \\ 4 & 11.04 .01 \\ 5 & 11.04 .01-010 \\ 4 & 11.04 .02 \\ 5 & 11.04 .02-010 \\ 4 & 11.04 .03 \\ 5 & 11.04 .03-010 \\ 4 & 11.04 .04 \\ 4 & \\ & \\ 7 & \\ 7 & \\ 7 & \\ 7 & \\ 7 & \end{array}$

NOME DA CONTA

Milho Grão

Culturas Perenes

Pastagens Andropogum

Outras Atividades Agropecuárias

Centro de Resultados Indiretos

Estoques de Defensivos

Roundup

Culturas Anuais

Milho Grão

Culturas Perenes

Pastagens Andropogum

Outras Atividades Agropecuárias

Centro de Resultados Indiretos

Estoques de Alimentos Volumosos

Estoques de Alimentos Concentrados

Farelo de Soja

Pecuária de Leite

Outras Atividades Agropecuárias

Centro de Resultados Indiretos

Estoques de Medicamentos e Vacinas Ivomec

Centro de Resultados Indiretos

Estoques de Materiais de Consumo

Combustiveis e Lubrificantes

Centro de Resultados Indiretos

Peças de Reposição

Centro de Resultados Indiretos

Materiais de Limpeza e Conservação

Centro de Resultados Indiretos

Materiais de Construcão

Centro de Resultados Indiretos

Materiais de Escritório

Centro de Resultados Indiretos

Materiais de Consumo Geral

Centro de Resultados Indiretos

Outros Insumos e Materiais de Consumo

Centro de Resultados Indiretos

\section{DESPESAS ANTECIPADAS A CURTO PRAZO}

Despesas Antecipadas c, Seguros

Seguros Contra Sinistros

Despesas Antecipadas com Juros

Juros de Empréstimos

Despesas Antecipadas c/ Aluguéis

Aluguel de Veiculos, Maquinaria,

Equipamentos e Implementos

Outras Despesas Antecipadas a Curto Prazo 
Tabela 28. Elenco de Contas Completo (continuacão)

EMPRESA RURAL: FAZENDA BOCAINA

GRAU CODIGO

3

212

312.01

$4 \quad 12.01 .01$

5 12.01.01-001 a 099

$4 \quad 12.01 .02$

$5 \quad 12.01 .02-001$ a 099

$4 \quad 12.01 .03$

$6 \quad 12.01 .03-001$

$4 \quad 12.01 .04$

$5 \quad 12.01 .04-001$

$3 \quad 12.02$

$4 \quad 12.02 .01$

$5 \quad 12.02 .01-010$

$4 \quad 12.02 .02$

$5 \quad 12.02 .02-010$

412.02 .03

$5 \quad 12.02 .03-010$

$4 \quad 12.02 .04$

213

313.01

$4 \quad 13.01 .01$

$4 \quad 13.01 .02$

$4 \quad 13.01 .03$

$4 \quad 13.01 .04$

$3 \quad 13.02$

$4 \quad 13.02 .01$

$5 \quad 13.02 .01-010$

$6 \quad 13.02 .01-011$

$6 \quad 13.02 .01-012$

$6 \quad 13.02 .01-013$

$613.02 .01-014$

$513.02 .01-020$

$613.02 .01-021$

$6 \quad 13.02 .01-022$

$6 \quad 13.02 .01-023$

$513.02 .01-030$

$6 \quad 13.02 .01-031$

$6 \quad 13.02 .01-032$

$6 \quad 13.02 .01-033$

$5 \quad 13.02 .01-040$

6 13.02.01-041

$6 \quad 13.02 .01-042$

$6 \quad 13.02 .01-043$

$4 \quad 13.02 .02$

$5 \quad 13.02 .02-010$

$5 \quad 13.02 .02-020$
NOME DA CONTA

REALIZAVEL A LONGO PRAZO

CREDITOS A LONGO PRAZO

Titulos a Receber a Longo Prazo

A Destacar

Contas a Receber a Longo Prazo

A Destacar

Adiantamentos e Empréstimos

A Destacar

Aplicações Financeiras de Longo Prazo A Destacar

DESPESAS ANTECIPADAS A LONGO PRAZO

Despesas Antecipadas c/ Seguros

Seguro de Vida

Despesas Antecipadas c/ Juros Juros de Empréstimos

Despesas Antecipadas c/ Aluguéis Arrendamento de Terra

Outras Despesas Antecip. a Longo-Prazo

PERMANENTE

INVESTIMENTOS

Participacões em Outras Empresas

Participacões em Fundos de Investimentos

Imóveis para Renda ou Futura Utilização

Outros Investimentos

IMOBILIZADO

Intermediário

Veiculos

Caminhões

Utilitários

Automóveis

Diversos

Maquinaria

Máquinas

Tratores

Motores

Equipamentos e Implementos

Agricolas

Pecuários

Diversos

Móveis e Utensilios

Móveis de Escritório

Móveis Residenciais

Utensilios

Fixo

Terras

Construeões 
Tabola 28. Elenco de Contas Completo (continuacão)

EMPRESA RURAL: FAZENDA BOCAINA

\section{GRAU CODIGO}

$6 \quad 13.02 .02-021$

$6 \quad 13.02 .02-022$

$6 \quad 13.02 .02-023$

$5 \quad 13.02 .02-030$

$6 \quad 13.02 .02-031$

$6 \quad 13.02 .02-032$

$6 \quad 13.02 .02-033$

$5 \quad 13.02 .02-040$

$6 \quad 13.02 .02-041$

$6 \quad 13.02 .02-042$

$6 \quad 13.02 .02-043$

$5 \quad 13.02 .02-050$

$613.02 .02-051$

$6 \quad 13.02 .02-052$

$6 \quad 13.02 .02-053$

$4 \quad 13.02 .03$

$5 \quad 13.02 .03-010$

$5 \quad 13.02 .03-020$

$5 \quad 13.02 .03-030$

$513.02 .03-040$

$5 \quad 13.02 .03-050$

$5 \quad 13.02 .03-060$

$5 \quad 13.02 .03-070$

$4 \quad 13.02 .04$

$5 \quad 13.02 .04-010$

$6 \quad 13.02 .04-011$

$6 \quad 13.02 .04-012$

$6 \quad 13.02 .04-013$

$513.02 .04-020$

$613.02 .04-021$

$6 \quad 13.02 .04-022$

$6 \quad 13.02 .04-023$

$5 \quad 13.02 .04-030$

$6 \quad 13.02 .04-031$

$6 \quad 13.02 .04-032$

$6 \quad 13.02 .04-033$

$5 \quad 13.02 .05-040$

$6 \quad 13.02 .05-041$

313.03

$4 \quad 13.03 .01$

$4 \quad 13.03 .02$

$4 \quad 13.03 .03$

$5 \quad 13.03 .03-001$

$5 \quad 13.03 .03-002$

$513.03 .03-003$

$5 \quad 13.03 .03-004$
NOME DA CONTA

Administrativas

Residenciais

Diversas

Instalações

Agricolas

Pecuárias

Diversas

Melhoramentos

Infraestrutura

Eletrificacão, Comunicacão e Saneamento

Diversos

Culturas Perenes Formadas

Pastagens Naturais

Pastagens Artificiais

Matas Naturais

Depreciação Acumulada

De Veiculos

De Maquinaria

De Equipamentos e Implementos

De Contruções

De Instalacões

De Melhoramentos

De Culturas Perenes

Imobilizado em Andamento

Contruções em Andamento

Administrativas

Residenciais

Diversas

Instalações em Andamento

Agricolas

Pecuárias

Diversas

Melhoramentos em Andamento

Infraestrutura

Eletrificação, Comunicação e Saneamento

Diversos

Culturas Perenes em Formação

Pastagens Artificiais

\section{DIFERIDO}

Gastos de Implantação e Pré-Operacionais Estudos e Projetos

Melhorias

Desmatamento

Destocamento

Terraplenagem

Calagem 
Tabela 28. Elenco de Contas Completo (continuação)

EMPRESA RURAL: FAZENDA BOCAINA

GRAU CODIGO

$\begin{array}{ll}5 & 13.03 .03-005 \\ 5 & 13.03 .03-006 \\ 5 & 13.03 .03-007 \\ 4 & 13.03 .04 \\ 5 & 13.03 .04-010 \\ 5 & 13.03 .04-020 \\ 5 & 13.03 .04-030\end{array}$

12

221

$3 \quad 21.01$

$4 \quad 21.01 .01$

$3 \quad 21.02$

421.02 .01

$3 \quad 21.03$

421.03 .01

$4 \quad 21.03 .02$

421.03 .03

$4 \quad 21.03 .04$

$3 \quad 21.04$

421.04 .01

$4 \quad 21.04 .02$

$4 \quad 21.04 .03$

$4 \quad 21.04 .04$

$4 \quad 21.04 .05$

$3 \quad 21.05$

$4 \quad 21.05 .01$

$4 \quad 21.05 .02$

$4 \quad 21.05 .03$

$4 \quad 21.05 .04$

421.05 .05

421.05 .06

$3 \quad 21.06$

$4 \quad 21.06 .01$

$4 \quad 21.06 .02$

$4 \quad 21.06 .03$

421.06 .04

$4 \quad 21.06 .05$

$3 \quad 21.07$

$4 \quad 21.07 .01$ a 099

$3 \quad 21.08$
NOME DA CONTA

Irrigacão

Drenagem

Outras Melhorias

Amortizacão Acumulada

De Gastos de Implantacão e

Pré-Operacionais.

De Estudos e Projetos

De Melhorias

\author{
PASSIVO \\ CIRCULANTE \\ FORNECEDORES \\ Cooperativa de Leite \\ TITULOS A PAGAR \\ Duplicata Bradesco \\ SALARIOS A PAGAR \\ Pessoal Administrativo \\ Mão-de-Obra Permanente \\ Mão-de-obra Temporária \\ Servicos de Terceiros
}

ENCARGOS SOCIAIS A RECOLHER

IAPAS a Recolher

FGTS a Recolher

Contribuicão Sindical a Recolher

Imposto de Renda na Fonte

Seguro de Vida

IMPOSTOS A PAGAR

ICM a Pagar

ISS a Pagar

PIS a Pagar

PRORURAL a Pagar

ITR a Pagar

Imposto de Renda na Fonte - Terceiros

CONTAS A PAGAR

Energia Elétrica

Agua

Telefone, Telex e Fax

Aluguéis e Arrendamentos

Outras Contas a Pagar

EMPRESTIMOS A PAGAR

A Destacar

OUTRAE OBRIGACOES DE CURTO PRAZO 
Tabola 28. Elenco de Contas Completo (continuacão)

EMPRESA RURAL: FAZENDA BOCAINA

\begin{tabular}{|c|c|c|}
\hline GRAU & CODIGO & NOME DA CONTA \\
\hline 2 & 22 & EXIGIVEL A LONGO-PRAZO \\
\hline 3 & 22.01 & FINANCIAMENTOS \\
\hline 4 & 22.01 .01 a 099 & A Destacar \\
\hline 3 & 22.02 & TITULOS A PAGAR A LONGO PRAZO \\
\hline & & \\
\hline 2 & 23 & RESULTADOS DE EXERCICIOS FUTUROS \\
\hline 3 & 23.01 & RECEITAS ANTECIPADAS \\
\hline 4 & 23.01 .01 a 099 & A Destacar \\
\hline 3 & 23.02 & CUSTOS OU DESPESAS DAS RECEITAS \\
\hline 4 & 23.02 .01 a 099 & $\begin{array}{l}\text { ANTECIPADAS } \\
\text { A Destacar }\end{array}$ \\
\hline 1 & 3 & PATRIMONIO LIQUIDO \\
\hline 2 & 31 & CAPITAL \\
\hline 2 & 32 & RESERVAS \\
\hline 3 & 32.02 & RESERVAS DE REAVALIACAO \\
\hline 2 & 33 & LUCROS (OU PREJUIZOS) ACUMULADOS \\
\hline 1 & 4 & RECEITAS \\
\hline 2 & 41 & RECEITAS OPERACIONAIS \\
\hline 3 & 41.01 & $\begin{array}{l}\text { RECEITA OPERACIONAL BRUTA - } \\
\text { INVENTARIO PERMANENTE }\end{array}$ \\
\hline 4 & 41.01 .00 & Receita Op. Bruta-Inventário Permanente \\
\hline 5 & $41.01 .00-100$ & Culturas Anuais \\
\hline 6 & $41.01 .00-110$ & Milho Grão \\
\hline 7 & $41.01 .00-112$ & Produto Acabado \\
\hline 4 & 41.01 .01 & Vendas de Produtos Agropecuários \\
\hline 5 & $41.01 .01-100$ & Culturas Anuais \\
\hline 6 & $41.01 .01-110$ & Milho Grão \\
\hline 7 & $41.01 .01-112$ & Produto Acabado \\
\hline 4 & 41.01 .02 & Consumo Interno de Produtos Agropecuários \\
\hline 5 & $41.01 .02-100$ & Culturas Anuais \\
\hline 6 & $41.01 .02-110$ & Milho Grão \\
\hline 7 & $41.01 .02-112$ & Produto Acabado \\
\hline 4 & 41.01 .03 & Pagamentos em Espécie c,' Produtos Agrop. \\
\hline 5 & $41.01 .03-100$ & Culturas Anuais \\
\hline 6 & $41.01 .03-110$ & Milho Grão \\
\hline 7 & $41.01 .03-112$ & Produto Acabado \\
\hline 4 & 41.01 .04 & Uso Interno de Produtos Agropecuários \\
\hline 5 & $41.01 .04-100$ & Culturas Anuais \\
\hline 6 & $41.01 .04-110$ & Milho Grão \\
\hline 7 & $41.01 .04-112$ & Produto Acabado \\
\hline 4 & 41.01 .05 & Acréscimos nos Estoques Devidos à Produção \\
\hline 5 & $41.01 .05-100$ & Culturas Anuais \\
\hline
\end{tabular}


Tabela 28. Elenco de Contas Completo (continuação)

\section{EMPRESA RURAL: FAZENDA BOCAINA}

\section{GRAU CODIGO}

$\begin{array}{ll}6 & 41.01 .05-110 \\ 7 & 41.01 .05-112 \\ 4 & 41.01 .06 \\ 5 & 41.01 .06-100 \\ 6 & 41.01 .06-110 \\ 7 & 41.01 .06-112\end{array}$

$3 \quad 41.02$

$4 \quad 41.02 .00$

$5 \quad 41.02 .00-200$

$6 \quad 41.02 .00-210$

$7 \quad 41.02 .00-211$

$5 \quad 41.02 .00-300$

$6 \quad 41.02 .00-310$

$5 \quad 41.02 .00-400$

$4 \quad 41.02 .01$

$5 \quad 41.02 .01-300$

$6 \quad 41.02 .01-310$

$5 \quad 41.02 .01-400$

$4 \quad 41.02 .02$

$5 \quad 41.02 .02-300$

$6 \quad 41.02 .02-310$

$5 \quad 41.02 .02-400$

$4 \quad 41.02 .03$

$5 \quad 41.02 .03-300$

$6 \quad 41.02 .03-310$

$5 \quad 41.02 .03-400$

$4 \quad 41.02 .04$

$5 \quad 41.02 .04-200$

$6 \quad 41.02 .04-210$

$7 \quad 41.02 .04-211$

$5 \quad 41.02 .04-300$

$6 \quad 41.02 .04-310$

$5 \quad 41.02 .04-400$

$4 \quad 41.02 .05$

$5 \quad 41.02 .05-300$

$641.02 .05-310$

$5 \quad 41.02 .05-400$

341.03

$4 \quad 41.03 .00$

$5 \quad 41.03 .00-100$

$6 \quad 41.03 .00-110$

$7 \quad 41.03 .00-112$

$5 \quad 41.03 .00-300$

$6 \quad 41.03 .00-310$
NOME DA CONTA

Milho Grão

Produto Acabado

Alterações de Preços Reais dos Estoques

Culturas Anuais

Milho Grão

Produto Acabado

RECEITA OPERACIONAL BRUTA INVENTARIO PERIODICO

Receita Op. Bruta-Inventário Periódico

Culturas Perenes

Pastagens Andropogum

Em Manutencão

Animais e Produtos Animais

Pecuária de Leite

Outras Atividades Agropecuárias

Vendas de Produtos Agropecuários

Animais e Produtos Animais

Pecuária de Leite

Outras Atividades Agropecuárias

Consumo Interno de Produtos Agropecuários

Animais e Produtos Animais

Pecuária de Leite

Outras Atividades Agropecuárias

Pagamentos em Espécie c/ Produtos Agrop.

Animais e Produtos Animais

Pecuária de Leite

Outras Atividades Agropecuárias

Uso Interno de Produtos Agropecuários

Culturas Perenes

Pastagens Andropogum

Em Manutencão

Animais e Produtos Animais

Pecuária de Leite

Outras Atividades Agropecuárias

Variações dos Estoques no Periodo

(Estoque Final - Estoque Inicial)

Animais e Produtos Animais

Pecuária de Leite

Outras Atividades Agropecuárias

RECEITA OPERACIONAL BRUTA -

APROPRIACAAO DIRETA

Receita Op. Bruta-Apropriação Direta

Culturas Anuais

Milho Grão

Produto Acabado

Animais e Produtos Animais

Pecuária de Leite 
Tabola 28. Elenco de Contas Completo (continuąão)

\section{EMPRESA RURAL: FAZENDA BOCAINA}

GRAU CODIGO$$
5
$$$$
4
$$

$7 \quad 41.04 .00-999$

$4 \quad 41.04 .01$

41. 03. 01-400

41.03 .01

41.03.01-100

41.03.01-110

41.03.01-112

41.03.01-300

41.03.01-310

41. 03. 01-400

41.03 .02

41.03.02-100

41. 03. 02-110

41. 03. 02-112

$41.03 .02-300$

41.03.02-310

41. 03. 02-400

41.03 .03

41.03.03-100

41. 03. 03-110

41. 03. 03-112

41.03.03-300

41.03.03-310

$41.03 .03-400$

41.03 .04

41.03.04-100

41. 03. 04-110

41.03.04-112

41.03.04-300

41. 03. 04-310

41. 03. 04-400

41.04

41.04 .02

41.04 .03

41.04 .04

41.05

41.05 .00

$41.05 .00-100$

41. 05. 00-110

41. 05. 00-112

41. 05. 00-200

$41.05 .00-210$

$41.05 .00-211$

41.05: 00-300
NOME DA CONTA

Outras Atividades Agropecuárias

Vendas de Produtos Agropecuários

Culturas Anuais

Milho Grão

Produto Acabado

Animais e Produtos Animais

Pecuária de Leite

Outras Atividades Agropecuárias

Consumo Interno de Produtos Agropecuários

Culturas Anuais Milho Grão

Produto Acabado

Animais e Produtos Animais

Pecuária de Leite

Outras Atividades Agropecuárias

Pagamentos em Espécie c/ Produtos Agrop.

Culturas Anuais Milho Grão

Produto Acabado

Animais e Produtos Animais

Pecuária de Leite

Outras Atividades Agropecuárias

Uso Interno de Produtos Agropecuários

Culturas Anuais

Milho Grão

Produto Acabado

Animais e Produtos Animais

Pecuária de Leite

Outras Atividades Agropecuárias

\section{RECEITA OPERACIONAL BRUTA -}

PRESTACOES DE SERVICOS

Receita Op.Bruta-Prestacões de Servicos Centro de Resultados Indiretos

Aluguel de Veiculos, Maquinaria,

Equipamentos e Implementos

Aluguel de Animais de Trabalho

Servicos de Mão-de-Obra

Outras Prestacões de Servicos

RECEITA OPERACIONAL BRUTA - TOTAIS

Receita Operacional Bruta - Totais

Culturas Anuais

Milho Grão

Produto Acabado

Culturas Perenes

Pastagens Andropogum

Em Manutencão

Animais e Produtos Animais 
Tabela 28. Elenco de Contas Completo (continuação)

\section{EMPRESA RURAL: FAZENDA BOCAINA}

\section{GRAU CODIGO}

$\begin{array}{ll}6 & 41.05 .00-310 \\ 5 & 41.05 .00-400 \\ 7 & 41.05 .00-999 \\ 4 & 41.05 .01 \\ 5 & 41.05 .01-100 \\ 6 & 41.05 .01-110 \\ 7 & 41.05 .01-112 \\ 5 & 41.05 .01-300 \\ 6 & 41.05 .01-310 \\ 5 & 41.05 .01-400 \\ 4 & 41.05 .02 \\ 5 & 41.05 .02-100 \\ 6 & 41.05 .02-110 \\ 7 & 41.05 .02-112 \\ 5 & 41.05 .02-300 \\ 6 & 41.05 .02-310 \\ 5 & 41.05 .02-400 \\ 4 & 41.05 .03 \\ 5 & 41.05 .03-100 \\ 6 & 41.05 .03-110 \\ 7 & 41.05 .03-112 \\ 5 & 41.05 .03-300 \\ 6 & 41.05 .03-310 \\ 5 & 41.05 .03-400 \\ 4 & 41.05 .04 \\ 5 & 41.05 .04-100 \\ 6 & 41.05 .04-110 \\ 7 & 41.05 .04-112 \\ 5 & 41.05 .04-200 \\ 6 & 41.05 .04-210 \\ 7 & 41.05 .04-211 \\ 5 & 41.05 .04-300 \\ 6 & 41.05 .04-310 \\ 5 & 41.05 .04-400 \\ 4 & 41.05 .05 \\ 5 & 41.05 .05-100 \\ 6 & 41.05 .05-110 \\ 7 & 41.05 .05-112 \\ 5 & 41.05 .05-300 \\ 6 & 41.05 .05-310 \\ 5 & 41.05 .05-400 \\ 4 & 41.05 .06 \\ 7 & 41.05 .06-999 \\ 3 & 41.06 \\ 4 & 41.06 .00 \\ 4 & 41.06 .10 \\ 4 & 41.06 .11 \\ 4 & 41.06 .12 \\ & \\ 5 & \end{array}$

\section{NOME DA CONTA}

Pecuária de Leite

Outras Atividades Agropecuárias

Centro de Resultados Indiretos

Vendas de Produtos Agropecuários

Culturas Anuais

Milho Grão

Produto Acabado

Animais e Produtos Animais

Pecuária de Leite

Outras Atividades Agropecuárias

Consumo Interno de Produtos Agropecuários

Culturas Anuais

Milho Grão

Produto Acabado

Animais e Produtos Animais

Pecuária de Leite

Outras Atividades Agropecuárias

Pagamentos em Espécie c/l Produtos Agrop.

Culturas Anuais

Milho Grão

Produto Acabado

Animais e Produtos Animais

Pecuária de Leite

Outras Atividades Agropecuárias

Uso Interno de Produtos Agropecuários

Culturas Anuais

Milho Grão

Produto Acabado

Culturas Perenes

Pastagens Andropogum

Em Manutenção

Animais e Produtos Animais

Pecuária de Leite

Outras Atividades Agropecuárias

Alterações dos Estoques no Periodo

Culturas Anuais

Milho Grão

Produto Acabado

Animais e Produtos Animais

Pecuária de Leite

Outras Atividades Agropecuárias

Prestações de Serviços

Centro de Resultados Indiretos

\section{RECEITAS FINANCEIRAS}

Receitas Financeiras

Receitas Financeiras (Juros e Corręão)

Receitas de Titulos a Receber

Receitas de Aplicaqões Mercado Financeiro 
Tabela 28. Elenco de Contas Completo (continuação)

\section{EMPRESA RURAL: FAZENDA BOCAINA}

GRAU CODIGO

$\begin{array}{ll}4 & 41.06 .13 \\ 4 & 41.06 .20 \\ 4 & 41.06 .21 \\ 4 & 41.06 .22\end{array}$

242

$3 \quad 42.01$

$4 \quad 42.01 .00$

$5 \quad 42.01 .00-100$

$6 \quad 42.01 .00-110$

$7 \quad 42.01 .00-112$

$4 \quad 42.01 .01$

$5 \quad 42.01 .01-100$

$6 \quad 42.01 .01-110$

$7 \quad 42.01 .01-112$

442.01 .02

$5 \quad 42.01 .02-100$

$6 \quad 42.01 .02-110$

$7 \quad 42.01 .02-112$

$4 \quad 42.01 .03$

5 42.01.03-100

$642.01 .03-110$

$7 \quad 42.01 .03-112$

$4 \quad 42.01 .04$

$5 \quad 42.01 .04-100$

$6 \quad 42.01 .04-110$

$7 \quad 42.01 .04-112$

$4 \quad 42.01 .05$

5 42.01.05-100

$6 \quad 42.01 .05-110$

$7 \quad 42.01 .05-112$

$3 \quad 42.02$

$4 \quad 42.02 .00$

$542.02 .00-300$

$6 \quad 42.02 .00-310$

$542.02 .00-400$

$4 \quad 42.02 .01$

$5 \quad 42.02 .01-300$

$6 \quad 42.02 .01-310$

5 42.02.01-400

$4 \quad 42.02 .02$

$5 \quad 42.02 .02-300$

$6 \quad 42.02 .02-310$

$542.02 .02-400$

243
NOME DA CONTA

Outras Receitas Financeiras

Ganhos (Perdas) nos Créditos Operacionais

Ganhos nos Créditos Operacionais

(-)Perdas nos Créditos Operacionais

DEDUGOES DE RECEITAS OPERACIONAIS

DEDUCOES DA RECEITA OPERACIONAL BRUTA-

INVENTARIO PERMANENTE

Deduções da Receita Bruta-Inv.Permanente

Culturas Anuais

Milho Grão

Produto Acabado

Valor Contábil do Produto Vendido

Culturas Anuais

Milho Grão

Produto Acabado

Valor Contábil do Produto Consumido

Culturas Anuais

Milho Grão

Produto Acabado

Valor Contábil do Produto p/ Pagamento

Culturas Anuais Milho Grão

Produto Acabado

Valor Contábil do Produto Usado

Culturas Anuais Milho Grão

Produto Acabado

Valor Contábil das Perdas

Culturas Anuais Milho Grão

Produto Acabado

DEDUCOES DA RECEITA OPERACIONAL BRUTA-

INVENTARIO PERIODICO

Deduções da Receita Bruta-Inv.Periódico

Animais e Produtos Animais

Pecuária de Leite

Outras Atividades Agropecuárias

Compras de Produtos Agropecuários

Animais e Produtos Animais

Pecuária de Leite

Outras Atividades Agropecuárias

Recebimentos em Espécie de Prod. Agrop. Animais e Produtos Animais

Pecuária de Leite

Outras Atividades Agropecuárias

RECEITAS NAO-OPERACIONAIS 
Tabela 28. Elenco de Contas Completo (continuação)

EMPRESA RURAL: FAZENDA BOCAINA

GRAU CODIGO

$\begin{array}{ll}3 & 43.00 \\ 4 & 43.00 .00 \\ 3 & 43.01 \\ 4 & 43.01 .00 \\ 3 & 43.02 \\ 4 & 43.02 .00 \\ 3 & 43.03 \\ 4 & 43.03 .00 \\ 3 & 43.04 \\ 4 & 43.04 .00 \\ 3 & 43.05 \\ 4 & 43.05 .00 \\ 3 & 43.06 \\ 4 & 43.06 .00 \\ 3 & 43.07 \\ 4 & 43.07 .00\end{array}$

15

251

351.00

$4 \quad 51.00 .00$

$5 \quad 51.00 .00-100$

$6 \quad 51.00 .00-110$

$7 \quad 51.00 .00-111$

$5 \quad 51.00 .00-200$

$6 \quad 51.00 .00-210$

$7 \quad 51.00 .00-211$

$5 \quad 51.00 .00-300$

$6 \quad 51.00 .00-310$

$5 \quad 51.00 .00-400$

$7 \quad 51.00 .00-999$

$3 \quad 51.01$

$4 \quad 51.01 .00$

$5 \quad 51.01 .00-100$

$6 \quad 51.01 .00-110$

$7 \quad 51.01 .00-111$

$5 \quad 51.01 .00-200$

$6 \quad 51.01 .00-210$

$7 \quad 51.01 .00-211$

$5 \quad 51.01 .00-300$

$6 \quad 51.01 .00-310$
NOME DA CONTA

RECEITAS NAO-OPERACIONAIS

Receitas Não-Operacionais

GANHOS NAS VENDAS DE BENS DE CAPITAL Ganhos nas Vendas de Bens de Capital

ALUGUEIS E ARRENDAMENTOS

Aluguéis e Arrendamentos

RECEITAS DE EMPRESTIMOS A TERCEIROS Receitas de Empréstimos a Terceiros

INDENIZACOES DE SEGUROS

Indenizações de Seguros

RECEBIMENTOS EM ESPECIE

Recebimentos em Espécie

DOACOES E HERANCAS

Doações e Heranças

OUTRAS RECEITAS NAO-OPERACIONAIS

Outras Receitas Não-Operacionais

CUSTOS DE PRODUCAO

CUSTOS VARIAVEIS DE PRODUCAO

CUSTOS VARIAVEIS DE PRODUCAO

Custos Variáveis de Producão

Culturas Anuais

Milho Grão

Em Crescimento

Culturas Perenes

Pastagens Andropogum

Em Manutenção

Animais e Produtos Animais

Pecuária de Leite

Outras Atividades Agropecuárias

Centro de Resultados Indiretos

MAO-DE-OBRA TEMPORARIA

Mão-de-Obra Temporária

Culturas Anuais

Milho Grão

Em Crescimento

Culturas Perenes

Pastagens Andropogum

Em Manuteneão

Animais e Produtos Animais

Pecuária de Leite 
Tabela 2B. Elenco de Contas Completo (continuąão)

EMPRESA RURAL: FAZENDA BOCAINA

\section{GRAU CODIGO}

$51.01 .00-400$

$51.01 .00-999$

51.01 .01

$51.01 .01-100$

$51.01 .01-110$

$51.01 .01-111$

$51.01 .01-200$

$51.01 .01-210$

$51.01 .01-211$

$51.01 .01-300$

$51.01 .01-310$

$51.01 .01-400$

$51.01 .01-999$

51.01 .02

51.01.02-100

51.01.02-110

51.01.02-111

$51.01 .02-200$

$51.01 .02-210$

51.01.02-211

51.01.02-300

$51.01 .02-310$

$51.01 .02-400$

51.01.02-999

51.01 .03

$51.01 .03-100$

51.01.03-110

51.01.03-111

$51.01 .03-200$

51.01.03-210

51.01.03-211

$51.01 .03-300$

$51.01 .03-310$

$51.01 .03-400$

51.01.03-999

51.02

51.02 .00

$51.02 .00-100$

51.02.00-110

51.02.00-111

$51.02 .00-200$

$51.02 .00-210$

$51.02 .00-211$

$51.02 .00-300$

$51.02 .00-310$

$51.02 .00-400$

51.02.00-999
NOME DA CONTA

Outras Atividades Agropecuárias Salários

Centro de Resultados Indiretos

Culturas Anuais

Milho Grão

Em Crescimento

Culturas Perenes

Pastagens Andropogum

Em Manutenção

Animais e Produtos Animais

Pecuária de Leite

Outras Atividades Agropecuárias

Centro de Resultados Indiretos

Encargos Sociais

Culturas Anuais

Milho Grão

Em Crescimento

Culturas Perenes

Pastagens Andropogum

Em Manutencão

Animais e Produtos Animais

Pecuária de Leite

Outras Atividades Agropecuárias

Centro de Resultados Indiretos

Outros Pagamentos

Culturas Anuais Milho Grão

Em Crescimento

Culturas Perenes

Pastagens Andropogum

Em Manutenção

Animais e Produtos Animais

Pecuária de Leite

Outras Atividades Agropecuárias

Centro de Resultados Indiretos

\section{SERVICOS DE TERCEIROS}

Servicos de Terceiros

Culturas Anuais

Milho Grão

Em Crescimento

Culturas Perenes

Pastagens Andropogum

Em Manuteneão

Animais e Produtos Animais

Pecuária de Leite

Outras Atividades Agropecuárias

Centro de Resultados Indiretos 
Tabela 28. Elenco de Contas Completo (continuação)

EMPRESA RURAL: FAZENDA BOCAINA

\section{GRAU CODIGO}

$4 \quad 51.02 .01$

$5 \quad 51.02 .01-100$

$6 \quad 51.02 .01-110$

$7 \quad 51.02 .01-111$

$5 \quad 51.02 .01-200$

$6 \quad 51.02 .01-210$

$7 \quad 51.02 .01-211$

$5 \quad 51.02 .01-300$

$6 \quad 51.02 .01-310$

$5 \quad 51.02 .01-400$

$7 \quad 51.02 .01-999$

$4 \quad 51.02 .02$

$5 \quad 51.02 .02-100$

$6 \quad 51.02 .02-110$

$7 \quad 51.02 .02-111$

$5 \quad 51.02 .02-200$

$6 \quad 51.02 .02-210$

$751.02 .02-211$

$5 \quad 51.02 .02-300$

$6 \quad 51.02 .02-310$

$5 \quad 51.02 .02-400$

$7 \quad 51.02 .02-999$

$4 \quad 51.02 .03$

$5 \quad 51.02 .03-100$

$6 \quad 51.02 .03-110$

$751.02 .03-111$

$5 \quad 51.02 .03-200$

$6 \quad 51.02 .03-210$

$7 \quad 51.02 .03-211$

$5 \quad 51.02 .03-300$

$6 \quad 51.02 .03-310$

$5 \quad 51.02 .03-400$

$7 \quad 51.02 .03-999$

$4 \quad 51.02 .04$

$5 \quad 51.02 .04-100$

$6 \quad 51.02 .04-110$

$751.02 .04-111$

$5 \quad 51.02 .04-200$

$6 \quad 51.02 .04-210$

$751.02 .04-211$

$5 \quad 51.02 .04-300$

$6 \quad 51.02 .04-310$

$5 \quad 51.02 .04-400$

$7 \quad 51.02 .04-999$

351.03

$4 \quad 51.03 .00$
NOME DA CONTA

Aluguel de Veiculos, Maquinaria, Equipamentos e Implementos

Culturas Anuais Milho Grão

Em Crescimento

Culturas Perenes

Pastagens Andropogum

Em Manutenção

Animais e Produtos Animais

Pecuária de Leite

Outras Atividades Agropecuárias

Centro de Resultados Indiretos

Aluguel de Animais de Trabalho

Culturas Anuais Milho Grão

Em Crescimento

Culturas Perenes

Pastagens Andropogum

Em Manutenção

Animais e Produtos Animais

Pecuária de Leite

Outras Atividades Agropecuárias

Centro de Resultados Indiretos

Servicos de Mão-de-Obra

Culturas Anuais Milho Grão

Em Crescimento

Culturas Perenes

Pastagens Andropogum

Em Manutenção

Animais e Produtos Animais

Pecuária de Leite

Outras Atividades Agropecuárias

Centro de Resultados Indiretos

Outros Servicos de Terceiros

Culturas Anuais

Milho Grão

Em Crescimento

Culturas Perenes

Pastagens Andropogum

Em Manutenção

Animais e Produtos Animais

Pecuária de Leite

Outras Atividades Agropecuárias

Centro de Resultados Indiretos

VEICULOS, MAQUINARIA, EQUIPAMENTOS E IMPLEMENTOS

Veic., Maq., Equip. Impl.(Combustiveis, 
Tabola 28. Elenco de Contas Completo (continuacião)

EMPRESA RURAL: FAZENDA BOCAINA

GRAU CODIGO

$51.03 .00-999$
51.03 .10
$51.03 .10-999$
51.03 .11
51.03 .12
51.03 .13
51.03 .14
51.03 .15
51.03 .20
$51.03 .20-999$
51.03 .21

51.04

51.04 .00

$51.04 .00-100$

$51.04 .00-110$

$51.04 .00-111$

51.04 .10

$51.04 .10-100$

$51.04 .10-110$

$51.04 .10-111$

51.04 .11

51.04 .12

51.04 .13

51.04 .14

51.04 .15

51.04 .20

51.04.20-100

51. 04. 20-110

51. 04. 20-111

51.04 .21

51.05

51.05 .00

51.05.00-100

51.05.00-110

51.05.00-111

51.05.00-200

51.05.00-210

51.05.00-211

51.05.00-999

51.05 .10

51.05.10-100

51.05.10-110

51.05.10-111

51.05.10-200

51.05.10-210

51.05. 10-211
NOME DA CONTA

Lubrificantes, Reparos e Manutencão)

Centro de Resultados Indiretos

Custo em Inventário Periódico

Compras

Centro de Resultados Indiretos

(+)Recebimentos em Espécie

$(-)$ Vendas

(-)Pagamentos em Espécie

(+)Variação do Estoque no Período

Custo em Apropriacão Direta

Centro de Resultados Indiretos

Compras

SEMENTES E MUDAS

Sementes e Mudas

Culturas Anuais

Milho Grão

Em Crescimento

Custo em Inventário Periódico

Culturas Anuais

Milho Grão

Compras

Em Crescimento

(+) Recebimentos em Espécie

$(-)$ Vendas

(-)Pagamentos em Espécie

(+)Variacão do Estoque no Periodo

Custo em Apropriação Direta

Culturas Anuais Milho Grão

Em Crescimento

Compras

FERTILIZANTES E CORRETIVOS

Fertilizantes e Corretivos

Culturas Anuais

Milho Grăo

Em Crescimento

Culturas Perenes

Pastagens Andropogum

Em Manutenção

Centro de Resultados Indiretos

Custo em Inventário Permanente

Culturas Anuais Milho Grão

Em Crescimento

Culturas Perenes

Pastagens Andropogum

Em Manutencão 
Tabela 28. Elenco de Contas Completo (continuacão)

\section{EMPRESA RURAL: FAZENDA BOCAINA}

\section{GRAU CODIGO}

$\begin{array}{ll}7 & 51.05 .10-999 \\ 4 & 51.05 .11 \\ 4 & 51.05 .20 \\ 5 & 51.05 .20-100 \\ 6 & 51.05 .20-110 \\ 7 & 51.05 .20-111 \\ 5 & 51.05 .20-200 \\ 6 & 51.05 .20-210 \\ 7 & 51.05 .20-211 \\ 7 & 51.05 .20-999 \\ 4 & 51.05 .21\end{array}$

51.06

51.06 .00

51.06.00-999

51.06 .10

51.06.10-999

51.06 .11

51.06 .12

51.06 .13

51.06 .14

51.06 .15

51.06 .20

51.06.20-999

51.06 .21

51.07

51.07 .00

$51.07 .00-300$

51.07.00-310

$51.07 .00-400$

51.07.00-999

51.07 .10

$51.07 .10-300$

$51.07 .10-310$

$51.07 .10-400$

$51.07 .10-999$

51.07 .11

51.07 .12

51.07 .20

$51.07 .20-300$

$51.07 .20-310$

$51.07 .20-400$

$51.07 .20-999$

51.07 .21

51.07 .22

51.08

51.08 .00
NOME DA CONTA

Centro de Resultados Indiretos

Valor Contábil do Insumo Usado

Custo em Apropriacão Direta

Culturas Anuais

Milho Grão

Em Crescimento

Culturas Perenes

Pastagens Andropogum

Em Manutenç̃o

Compras

Centro de Resultados Indiretos

DEFENSIVOS

Defensivos

Centro de Resultados Indiretos

Custo em Inventário Periódico

Compras

Centro de Resultados Indiretos

(+)Recebimentos em Espécie

$(-)$ Vendas

(-)Pagamentos em Espécie

(+)Variac̃a do Estoque no Periodo

Custo em Apropriação Direta

Compras

Centro de Resultados Indiretos

\section{ALIMENTOS CONCENTRADOS}

Alimentos Concentrados

Animais e Produtos Animais

Pecuária de Leite

Outras Atividades Agropecuárias

Centro de Resultados Indiretos

Custo em Inventário Permanente

Animais e Produtos Animais

Pecuária de Leite

Outras Atividades Agropecuárias

Centro de Resultados Indiretos

Valor Contábil do Insumo Usado

Valor de Mercado do Produto Usado

Custo em Apropriacão Direta

Animais e Produtos Animais

Pecuária de Leite

Outras Atividades Agropecuárias

Compras

Centro de Resultados Indiretos

Valor de Mercado do Produto Usado

ALIMENTOS VOLUMOSOS

Alimentos Volumosos 
Tab́la 28. Elenco de Contas Completo (continuacão)

EMPRESA RURAL: FAZENDA BOCAINA

GRAU CODIGO

5

6

5

7

4

5

6

5

7

4

4

4

7

4

7

4

4

4

4

4

4

7

4

3

4

7

4

7

4

4

4

4

4

4

7

4

3

4

7

2
3
4
5
6
$51.08 .00-300$

$51.08 .00-310$

$51.08 .00-400$

51.08.00-999

51.08 .10

$51.08 .10-300$

$51.08 .10-310$

$51.08 .10-400$

51.08.10-999

51.08 .11

51.08 .12

51.09

51.09 .00

51.09.00-999

51.09 .10

51.09.10-999

51.09 .11

51.09 .12

51.09 .13

51.09 .14

51.09 .15

51.09 .20

51.09.20-999

51.09 .21

51.10

51.10 .00

51.10.00-999

51.10 .10

51.10.10-999

51.10 .11

51.10 .12

51.10 .13

51.10 .14

51.10 .15

51.10 .20

$51.10 .20-999$

51.10 .31

51.11

51.11 .00

51.11.00-999

52

52.00

52.00 .00

52.00.00-100

$52.00 .00-110$
NOME DA CONTA

Animais e Produtos Animais

Pecuária de Leite

Outras Atividades Agropecuárias

Centro de Resultados Indiretos

Custo em Apropriacão Direta

Animais e Produtos Animais

Pecuária de Leite

Outras Atividades Agropecuárias Centro de Resultados Indiretos

Compras

Valor de Mercado do Produto Usado

MEDICAMENTOS E VACINAS

Medicamentos e Vacinas

Centro de Resultados Indiretos

Custo em Inventário Periódico

Compras

Centro de Resultados Indiretos

(+)Recebimentos em Espécie

$(-)$ Vendas

(-)Pagamentos em Espécie

(+)Variação do Estoque no Periodo

Custo em Apropriacão Direta

Centro de Resultados Indiretos Compras

MATERIAIS DE CONSUMO

Materiais de Consumo

Centro de Resultados Indiretos

Custo em Inventário Periódico

Compras

Centro de Resultados Indiretos

(+)Recebimentos em Espécie

(-) Vendas

(-)Pagamentos em Espécie

(+)Variação do Estoque no Período

Custo em Apropriação Direta

Centro de Resultados Indiretos

Compras

OUTROS CUSTOS VARIAVEIS DE PRODUCAO

Outros Custos Variáveis de Produção Centro de Resultados Indiretos

CUSTOS FIXOS DE PRODUGAO

CUSTOS FIXOS DE PRODUCAO

Custos Fixos de Producão

Culturas Anuais

Milho Grão 
Tabela 28. Elenco de Contas Completo (continuação)

EMPRESA RURAL: FAZENDA BOCAINA

\section{GRAU CODIGO}

$52.00 .00-111$

52.00.00-200

52.00.00-210

52.00.00-211

$52.00 .00-300$

$52.00 .00-310$

$52.00 .00-400$

52.00.00-999

52.01

52.01 .00

$52.01 .00-999$

52.01 .01

52.01.01-999

52.01 .02

52.01.02-999

52.01 .03

52.01.03-999

52.01 .04

52.01.04-999

52.01 .05

52.01.05-999

52.01 .06

52.01.06-999

52.02

52.02 .00

52.02.00-100

52.02.00-110

52.02.00-111

$52.02 .00-112$

$52.02 .00-200$

$52.02 .00-210$

$52.02 .00-211$

$52.02 .00-300$

$52.02 .00-310$

$52.02 .00-400$

$52.02 .00-999$

52.03

52.03 .00

52.03.00-999

52.03 .01

52.03.01-999

52.03 .02

52.03.02-999

52.04
NOME DA CONTA

Em Crescimento

Culturas Perenes

Pastagens Andropogum

Em Manutenção

Animais e Produtos Animais

Pecuária de Leite

Outras Atividades Agropecuárias

Centro de Resultados Indiretos

MAO-DE-OBRA PERMANENTE

Mão-de-Obra Permanente

Centro de Resultados Indiretos

Salários

Centro de Resultados Indiretos

Encargos Sociais

Centro de Resultados Indiretos

Outros Pagamentos

Centro de Resultados Indiretos

Custos Não-Caixa com Alimentação

Centro de Resultados Indiretos

Custos Não-Caixa com Moradia

Centro de Resultados Indiretos

Outros Custos Não-Caixa

Centro de Resultados Indiretos

CONSTRUCOES, INSTALACOES E MELHORAMENTOS

Construções, Instalações e Melhoramentos

(Reparos e Manutenção)

Culturas Anuais

Milho Grão

Em Crescimento

Produto Acabado

Culturas Perenes

Pastagens Andropogum

Em Manutenção

Animais e Produtos Animais

Pecuária de Leite

Outras Atividades Agropecuárias

Centro de Resultados Indiretos

TAXAS, IMPOSTOS, SEGUROS E LICENCAS

Taxas, Impostos, Seguros e Licencas Centro de Resultados Indiretos

Taxas e Impostos

Centro de Resultados Indiretos Seguros e Licenças

Centro de Resultados Indiretos

ALUGUEIS E ARRENDAMENTOS 
Tabela 28. Elenco de Contas Completo (continuacão)

\section{EMPRESA RURAL: FAZENDA BOCAINA}

GRAU CODIGO

$\begin{array}{ll}4 & 52.04 .00 \\ 5 & 52.04 .00-100 \\ 6 & 52.04 .00-110 \\ 7 & 52.04 .00-111 \\ 5 & 52.04 .00-200 \\ 6 & 52.04 .00-210 \\ 7 & 52.04 .00-211 \\ 5 & 52.04 .00-300 \\ 6 & 52.04 .00-310 \\ 5 & 52.04 .00-400 \\ 7 & 52.04 .00-999 \\ 4 & 52.04 .01 \\ 5 & 52.04 .01-300 \\ 6 & 52.04 .01-310 \\ 5 & 52.04 .01-400 \\ 7 & 52.04 .01-999 \\ 4 & 52.04 .02 \\ 5 & 52.04 .02-300 \\ 6 & 52.04 .02-310 \\ 5 & 52.04 .02-400 \\ 7 & 52.04 .02-999 \\ 4 & 52.04 .03 \\ 5 & 52.04 .03-100 \\ 6 & 52.04 .03-110 \\ 7 & 52.04 .03-111 \\ 5 & 52.04 .03-200 \\ 6 & 52.04 .03-210 \\ 7 & 52.04 .03-211 \\ 5 & 52.04 .03-300 \\ 6 & 52.04 .03-310 \\ 5 & 52.04 .03-400 \\ 7 & 52.04 .03-999 \\ 4 & 52.04 .04 \\ 5 & 52.04 .04-100 \\ 6 & 52.04 .04-110 \\ 7 & 52.04 .04-112 \\ 7 & 52.04 .04-999 \\ 4 & 52.04 .05 \\ 5 & 52.04 .05-100 \\ 6 & 52.04 .05-110 \\ 7 & 52.04 .05-111 \\ 5 & 52.04 .05-200 \\ 6 & 52.04 .05-210 \\ 7 & 52.04 .05-211 \\ 5 & 52.04 .05-400 \\ 7 & 52.04 .05-999 \\ 3 & 52.05 \\ 4 & 52.05 .00 \\ & 5\end{array}$

NOME DA CONTA

Aluguéis e Arrendamentos

Culturas Anuais

Milho Grão

Em Crescimento

Culturas Perenes

Pastagens Andropogum

Em Manutencão

Animais e Produtos Animais

Pecuária de Leite

Outras Atividades Agropecuárias

Centro de Resultados Indiretos

Aluguel de Pastagens de Terceiros

Animais e Produtos Animais

Pecuária de Leite

Outras Atividades Agropecuárias

Centro de Resultados Indiretos

Uso de Pastagens da Empresa

Animais e Produtos Animais

Pecuária de Leite

Outras Atividades Agropecuárias

Centro de Resultados Indiretos

Uso de Animais de Trabalho

Culturas Anuais

Milho Grão

Em Crescimento

Culturas Perenes

Pastagens Andropogum

Em Manutencão

Animais e Produtos Animais

Pecuária de Leite

Outras Atividades Agropecuárias

Centro de Resultados Indiretos

Aluguel de Depósitos e Terreiros

Culturas Anuais

Milho Grão

Produto Acabado

Centro de Resultados Indiretos

Arrendamento de Terras

Culturas Anuais

Milho Grão

Em Crescimento

Culturas Perenes

Pastagens Andropogum

Em Manutencão

Outras Atividades Agropecuárias

Centro de Resultados Indiretos

\section{DEPRECIACOES}

Depreciacões 
Tabela 28. Elenco de Contas Completo (continuação)

\section{EMPRESA RURAL: FAZENDA BOCAINA}

\section{GRAU CODIGO}

$5 \quad 52.05 .00-100$

$6 \quad 52.05 .00-110$

$5 \quad 52.05 .00-200$

$6 \quad 52.05 .00-210$

$5 \quad 52.05 .00-300$

$652.05 .00-310$

$5 \quad 52.05 .00-400$

$7 \quad 52.05 .00-999$

$4 \quad 52.05 .01$

$7 \quad 52.05 .01-999$

$4 \quad 52.05 .02$

$7 \quad 52.05 .02-999$

$4 \quad 52.05 .03$

$5 \quad 52.05 .03-100$

$652.05 .03-110$

5 52.05.03-200

$652.05 .03-210$

$5 \quad 52.05 .03-300$

$652.05 .03-310$

$5 \quad 52.05 .03-400$

$7 \quad 52.05 .03-999$

$4 \quad 52.05 .04$

$7 \quad 52.05 .04-999$

$4 \quad 52.05 .05$

$5 \quad 52.05 .05-100$

$6 \quad 52.05 .05-110$

$5 \quad 52.05 .05-200$

$652.05 .05-210$

$5 \quad 52.05 .05-300$

$6 \quad 52.05 .05-310$

$5 \quad 52.05 .05-400$

$7 \quad 52.05 .05-999$

$4 \quad 52.05 .06$

$7 \quad 52.05 .06-999$

$4 \quad 52.05 .07$

5 52.05.07-200

$652.05 .07-210$

$\begin{array}{ll}3 & 52.06 \\ 4 & 52.06 .00 \\ 7 & 52.06 .00-999\end{array}$

$\begin{array}{ll}2 & 53 \\ 3 & 53.01 \\ 4 & 53.01 .01 \\ 5 & 53.01 .01-100 \\ 6 & 53.01 .01-110 \\ 7 & 53.01 .01-111\end{array}$

\section{NOME DA CONTA}

\section{Culturas Anuais}

Milho Grão

Culturas Perenes

Pastagens Andropogum

Animais e Produtos Animais

Pecuária de Leite

Outras Atividades Agropecuárias

Centro de Resultados Indiretos

Depreciação de Veículos

Centro de Resultados Indiretos

Depreciacão de Maquinaria

Centro de Resultados Indiretos

Depreciacão de Equipament. e Implementos

Culturas Anuais

Milho Grão

Culturas Perenes

Pastagens Andropogum

Animais e Produtos Animais

Pecuária de Leite

Outras Atividades Agropecuárias Centro de Resultados Indiretos

Depreciação de Construcões

Centro de Resultados Indiretos

Depreciacão de Instalacões

Culturas Anuais

Milho Grão

Culturas Perenes

Pastagens Andropogum

Animais e Produtos Animais

Pecuária de Leite

Outras Atividades Agropecuárias

Centro de Resultados Indiretos

Depreciacão de Melhoramentos

Centro de Resultados Indiretos

Depreciação de Culturas Perenes

Culturas Perenes

Pastagens Andropogum

OUTROS CUSTOS FIXOS DE PRODUCAO

Outros Custos Fixos de Producão

Centro de Resultados Indiretos

AJUSTES DE CUSTOS VARIAVEIS E FIXOS

ALTERACOES NOS ESTOQUES DE CULTURAS

Anuais em Crescimento

Culturas Anuais

Milho Grão

Em Crescimento 
Tabela 28. Elenco de Contas Completo (continuacão)

EMPRESA RURAL: FAZENDA BOCAINA

GRAU CODIGO

$\begin{array}{ll}2 & 54 \\ 3 & 54.00 \\ 4 & 54.00 .00 \\ 5 & 54.00 .00-100 \\ 6 & 54.00 .00-110 \\ 5 & 54.00 .00-200 \\ 6 & 54.00 .00-210 \\ 5 & 54.00 .00-300 \\ 6 & 54.00 .00-310 \\ 5 & 54.00 .00-400 \\ 7 & 54.00 .00-999\end{array}$

16

261

$3 \quad 61.01$

$4 \quad 61.01 .00$

$4 \quad 61.01 .01$

$4 \quad 61.01 .02$

$3 \quad 61.02$

461.02 .00

$4 \quad 61.02 .01$

$4 \quad 61.02 .02$

$4 \quad 61.02 .03$

$4 \quad 61.02 .04$

$4 \quad 61.02 .05$

$4 \quad 61.02 .06$

$4 \quad 61.02 .07$

$4 \quad 61.02 .08$

$4 \quad 61.02 .09$

$4 \quad 61.02 .10$

$4 \quad 61.02 .11$

$4 \quad 61.02 .12$

$4 \quad 61.02 .13$

$3 \quad 61.03$

$4 \quad 61.03 .00$

$4 \quad 61.03 .10$

$4 \quad 61.03 .11$

$4 \quad 61.03 .12$

$4 \quad 61.03 .13$

$4 \quad 61.03 .14$

$4 \quad 61.03 .15$

$4 \quad 61.03 .16$

$4 \quad 61.03 .17$

$4 \quad 61.03 .18$

$4 \quad 61.03 .20$

$4 \quad 61.03 .21$

$4 \quad 61.03 .22$
NOME DA CONTA

CUSTOS DOS BENS E SERVICOS PRODUZIDOS CUSTOS DOS BENS E SERVICOS PRODUZIDOS

Custos dos Bens e Servicos Produzidos

Culturas Anuais

Milho Grão

Culturas Perenes

Pastagens Andropogum

Animais e Produtos Animais

Pecuária de Leite

Outras Atividades Agropecuárias

Centro de Resultados Indiretos

\section{DESPESAS}

DESPESAS OPERACIONAIS

DESPESAS COM VENDAS

Despesas com Vendas

Provisão para Devedores Duvidosos

Outras Despesas com Vendas

\section{DESPESAS ADMINISTRATIVAS}

Despesas Administrativas

Retiradas do(s) Proprietário(s)

Pessoal Administrativo

Veiculos, Maquinaria, Equip. e Implementos

Construções, Instalações e Melhoramentos

Servicos Profissionais Avulsos

Materiais de Consumo

Taxas, Impostos, Seguros e Licenças

Aluguéis

Energia Elétrica

Agua

Comunicacões

Despesas de Transporte

Outras Despesas Administrativas

DESPESAS FINANCEIRAS

Despesas Financeiras

Despesas Financeiras (Juros e Correç̃o)

Despesas com Fornecedores

Despesas com Titulos a Pagar

Despesas com Empréstimos Bancários

Despesas com Empréstimos de Terceiros

Despesas com Financiamentos

Despesas Bancárias

Impostos sobre Operações Financeiras

Outras Despesas Financeiras

Perdas (Ganhos) nas Obrigacões Operacionais Perdas nas Obrigações Operacionais

(-)Ganhos nas Obrigacões Operacionais 
Tabela 28. Elenco de Contas Completo (continuação)

\section{EMPRESA RURAL: FAZENDA BOCAINA}

\section{GRAU CODIGO}

361.04

$4 \quad 61.04 .00$

$4 \quad 61.04 .01$

361.05

$4 \quad 61.05 .00$

$4 \quad 61.05 .01$

$4 \quad 61.05 .02$

461.05 .03

$4 \quad 61.05 .04$

$4 \quad 61.05 .05$

$4 \quad 61.05 .06$

262

$3 \quad 62.00$

$4 \quad 62.00 .00$

$3 \quad 62.01$

$4 \quad 62.01 .00$

$4 \quad 62.01 .01$

$4 \quad 62.01 .02$

$4 \quad 62.01 .03$

$3 \quad 62.02$

$4 \quad 62.02 .00$

$4 \quad 62.02 .01$

362.03

$4 \quad 62.03 .00$

$4 \quad 62.03 .01$

$4 \quad 62.03 .02$

$4 \quad 62.03 .03$

$3 \quad 62.04$

$4 \quad 62.04 .00$

$4 \quad 62.04 .01$

362.05

$4 \quad 62.05 .00$

$4 \quad 62.05 .01$

263

$3 \quad 63.00$
NOME DA CONTA

DESPESAS LIQUIDAS FINANCEIRAS

Despesas Liquidas Financeiras

Despesas - Receitas Financeiras

OUTRAS DESPESAS OPERACIONAIS

Outras Despesas Operacionais

Depreciação de Veículos, Maquinaria, Equipamentos e Implementos

Depreciação de Construcões, Instalacões e Melhoramentos

Amortização de Gastos de Implantacão e Pré-Operacionais

Amortização de Estudos e Projetos

Amortização de Melhorias

Outras Despesas Operacionais

DESPESAS NAO-OPERACIONAIS

DESPESAS NAO-OPERACIONAIS

Despesas Não-Operacionais

PERDAS NAS VENDAS DE BENS DE CAPITAL

Perdas nas Vendas de Bens de Capital

Perdas nas Vendas de Veículos, Maquinaria, Equipamentos e Implementos

Perdas nas Vendas / Sucata de Construcões, Instalacões e Melhoramentos

Perdas nas Reformas de Culturas Perenes

PERDAS EXTRAORDINARIAS

Perdas Extraordinárias

Secas, Geadas, Tempestades, Granizo, Incêndios, etc.

RETIRADAS EM ESPECIE DE PRODUTOS

Retiradas em Espécie de Produtos

Consumo Interno

Pagamento de Servicos de Terceiros

Pagamento de Insumos / Materiais Consumo

PROVISAO PARA PERDAS EM INVESTIMENTOS

Provisão para Perdas em Investirientos

Provisão para Perdas em Investimentos

OUTRAS DESPESAS NAO-OPERACIONAIS

Outras Despesas Não-Operacionais

Outras Despesas Não-Operacionais

OUTRA DE⿱ DEPTESAG

OUTRAS DESPESAS 
Tabela 28. Elenco de Contas Completo (continuação)

EMPRESA RURAL: FAZENDA BOCAINA

GRAU CODIGO

463.00 .00

$3 \quad 63.01$

463.01 .00

463.01 .01

$3 \quad 63.02$

463.02 .00

$4 \quad 63.02 .01$

$4 \quad 63.02 .02$

463.02 .03

363.03

463.03 .00

$4 \quad 63.03 .01$

$4 \quad 63.03 .02$

17

271

371.00 .00

471.00 .00

$571.00 .00-100$

$671.00 .00-110$

$5 \quad 71.00 .00-200$

$671.00 .00-210$

$5 \quad 71.00 .00-300$

$671.00 .00-310$

$571.00 .00-400$

$771.00 .00-999$

272

372.01

472.01 .00

$572.01 .00-100$

$672.01 .00-110$

$5 \quad 72.01 .00-200$

$672.01 .00-210$

$572.01 .00-300$

$672.01 .00-310$

$572.01 .00-400$

$7 \quad 72.01 .00-999$

$3 \quad 72.02$

472.02 .00

$572.02 .00-100$

$672.02 .00-110$

$572.02 .00-200$

$672.02 .00-210$

$572.02 .00-300$
NOME DA CONTA

Outras Despesas

PROVISAO PARA IMPOSTOS

Provisão para Impostos

Provisão para Imposto de Renda

PARTICIPACOES E CONTRIBUICCOES

Participações e Contribuicões

Empregados

Administradores

Contribuições e Doạ̃ões

PERDAS (GANHOS) NOS ITENS MONETARIOS

Perdas (Ganhos) nos Itens Monetários

Perdas nos Itens Monetários

(-)Ganhos nos Itens Monetários

RESULTADOS

VALOR BRUTO DA PRODUCAO DO PERIODO

VALOR BRUTO DA PRODUCAO DO PERIODO

Valor Bruto da Producão do Período

Culturas Anuais Milho Grão

Culturas Perenes

Pastagens Andropogum

Animais e Produtos Animais

Pecuária de Leite

Outras Atividades Agropecuáriás

Centro de Resultados Indiretos

MARGEM SOBRE CUSTOS VARIAVEIS

MARGEM SOBRE CUSTOS VARIAVEIS

Margem sobre Custos Variáveis

Culturas Anuais

Milho Grão

Culturas Perenes

Pastagens Andropogum

Animais e Produtos Animais

Pecuária de Leite

Outras Atividades Agropecuárias

Centro de Resultados Indiretos

MARGEM S/ CUSTOS VARIAVEIS APOS ALOCACOES Margem s/ Custos Variáveis Ap. Alocacões Culturas Anuais Milho Grão

Culturas Perenes

Pastagens Andropogum

Animais e Produtos Animais 
Tabela 28. Elenco de Contas Completo (continuação)

EMPRESA RURAL: FAZENDA BOCAINA

\section{GRAU CODIGO}

$6 \quad 72.02 .00-310$

$5 \quad 72.02 .00-400$

273

373.01

473.01 .00

$5 \quad 73.01 .00-100$

$6 \quad 73.01 .00-110$

$5 \quad 73.01 .00-200$

$6 \quad 73.01 .00-210$

$5 \quad 73.01 .00-300$

$6 \quad 73.01 .00-310$

$5 \quad 73.01 .00-400$

$7 \quad 73.01 .00-999$

$3 \quad 73.02$

4

5

6

5

6

5

$6 \quad 73.02 .00-310$

$573.02 .00-400$

$2 \quad 74$

275

276

$2 \quad 77$
NOME DA CONTA

Pecuária de Leite

Outras Atividades Agropecuárias

LUCRO (PREJUIZO) BRUTO DA PRODUCAO

LUCRO (PREJUIZO) BRUTO DA PRODUCAO

Lucro (Prejuizo) Bruto da Producão Culturas Anuais

Milho Grão

Culturas Perenes

Pastagens Andropogum

Animais e Produtos Animais

Pecuária de Leite

Outras Atividades Agropecuárias

Centro de Resultados Indiretos

LUCRO BRUTO DA PRODUCAO APOS ALOCACCOES

Lucro Bruto da Producão Após Alocações

Culturas Anuais Milho Grão

Culturas Perenes

Pastagens Andropogum

Animais e Produtos Animais

Pecuária de Leite

Outras Atividades Agropecuárias

LUCRO (PREJUIZO) OPERACIONAL

LUCRO (PREJUIZO) ANTES DO I.R.

LUCRO (PREJUIZO) DEPOIS DO I.R.

LUCRO (PREJUIZO) LIQUIDO 
Seguindo a sequência dos procedimentos propostos, a Tabela 29, abaixo, apresenta o Livro Diário da Fazenda Bocaina contendo, primeiramente, os valores dos componentes patrimoniais levantados pelo Inventário (Estoques Iniciais, Imobilizado e demais itens do Balanco Patrimonial), de forma que o total dos débitos seja igual ao total dos créditos, em perfeito equilibrio. Posteriormente, esse livro apresenta os lançamentos dos principais fatos e transações que movimentaram as atividades dessa empresa, durante o período do mês de Dezembro de 1990.

4. As Transcricões para os Razonetes

A Tabela 30 corresponde a um dos livros auxiliares do Razão, o "Livro Caixa", que será utilizado na elaboracão do Demonstrativo de Fluxo de Caixa da empresa.

As contas $T$ ou razonetes, apresentadas em seguida (Figura 6), ilustram a transcrição dos registros do Livro Diário para o Livro Razão.

\section{Informativos Auxiliares}

Para completar o Controle de Estoques, já iniciado, a Tabela 31 descreve os Estoques Finais dos bens sob Inventário Periódico.

Cabe lembrar, que o Controle de Ativo Imobilizado já foi desenvolvido nas Tabelas 20 a 25 . 
Tabela 29. Livro Diário

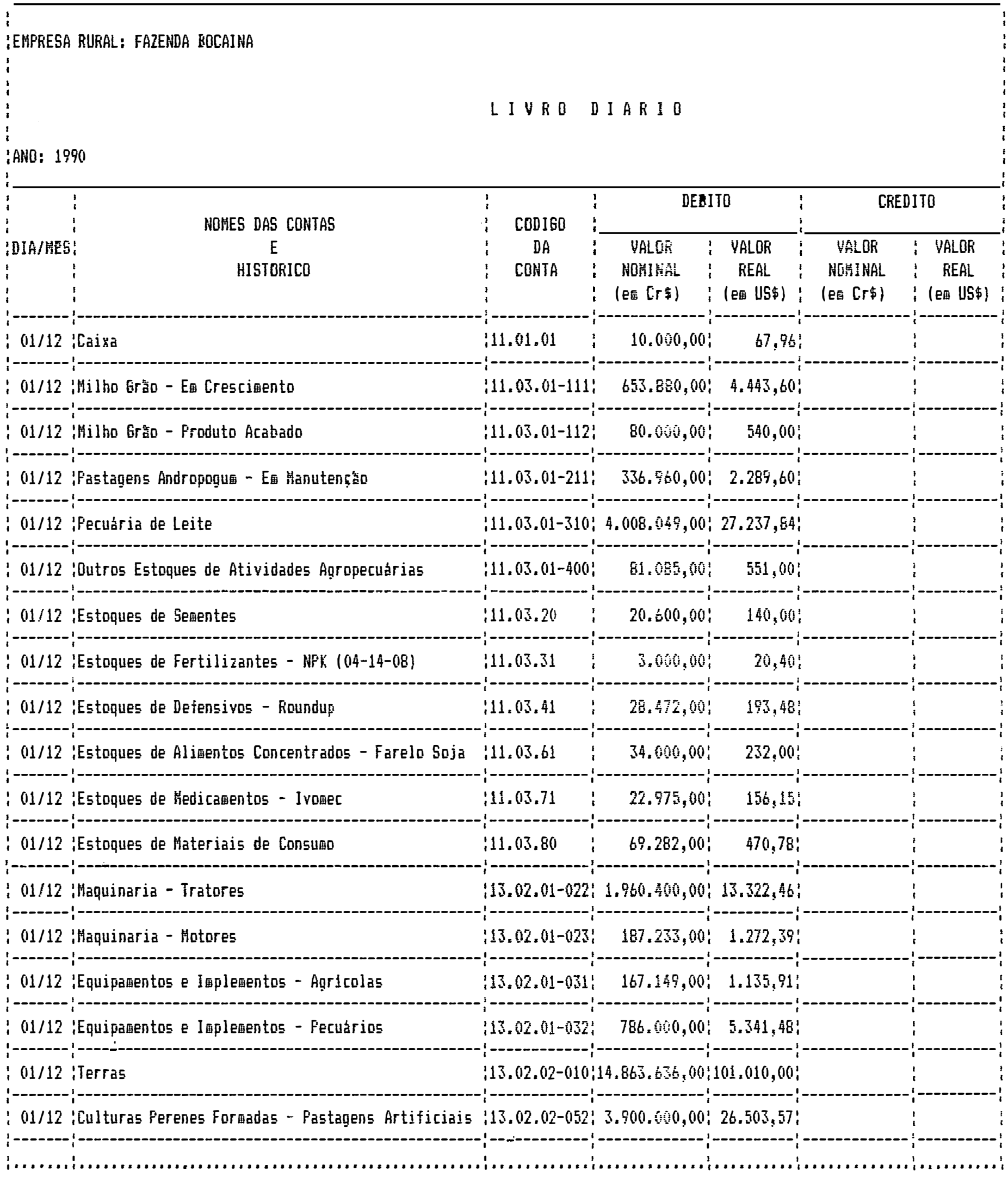

(continua) 


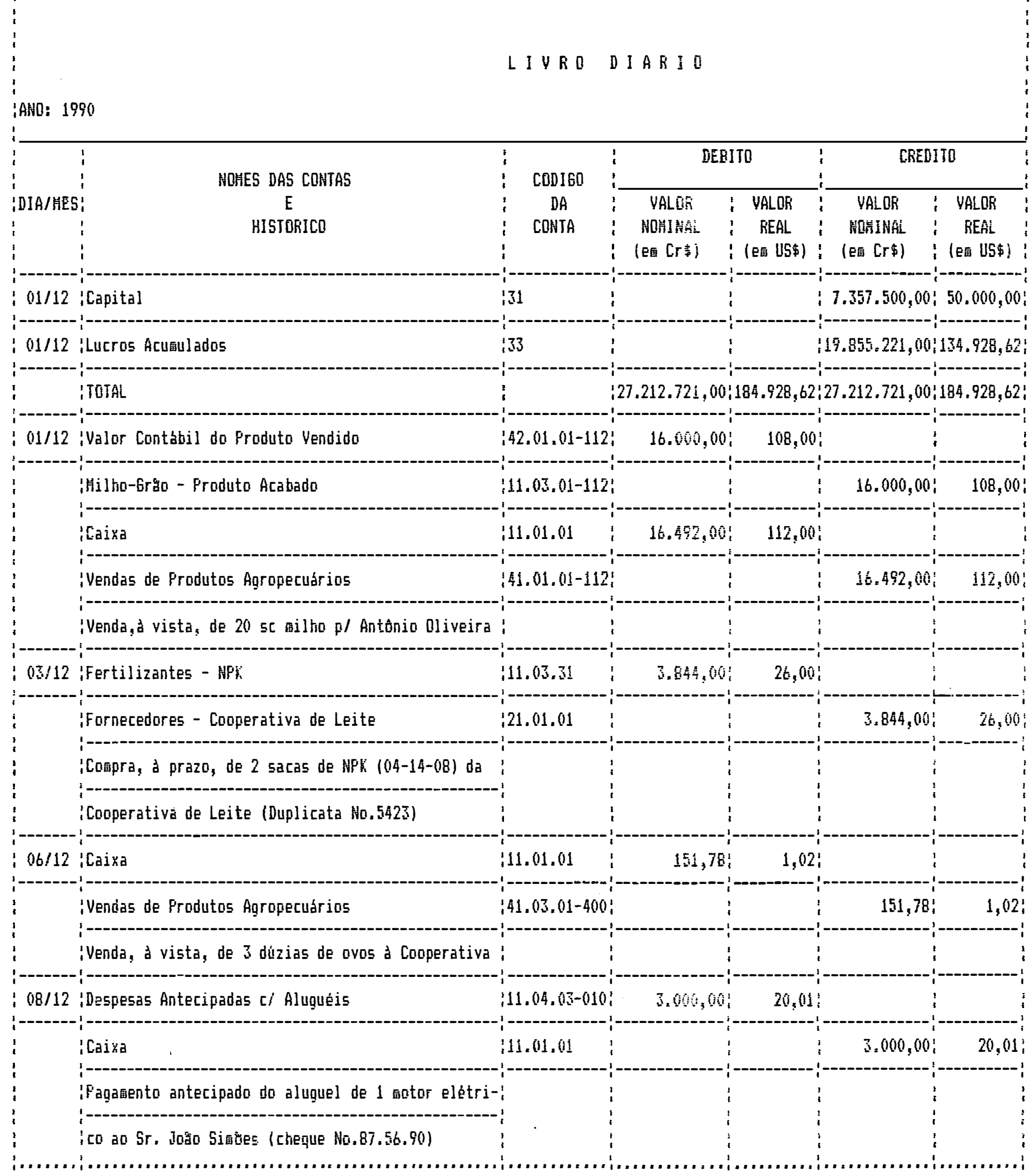




\section{'EMFFESA RUURAL: FAIEHDA BOCAIHA}

\section{LIVRO DIAFID}

:ANO: 1990

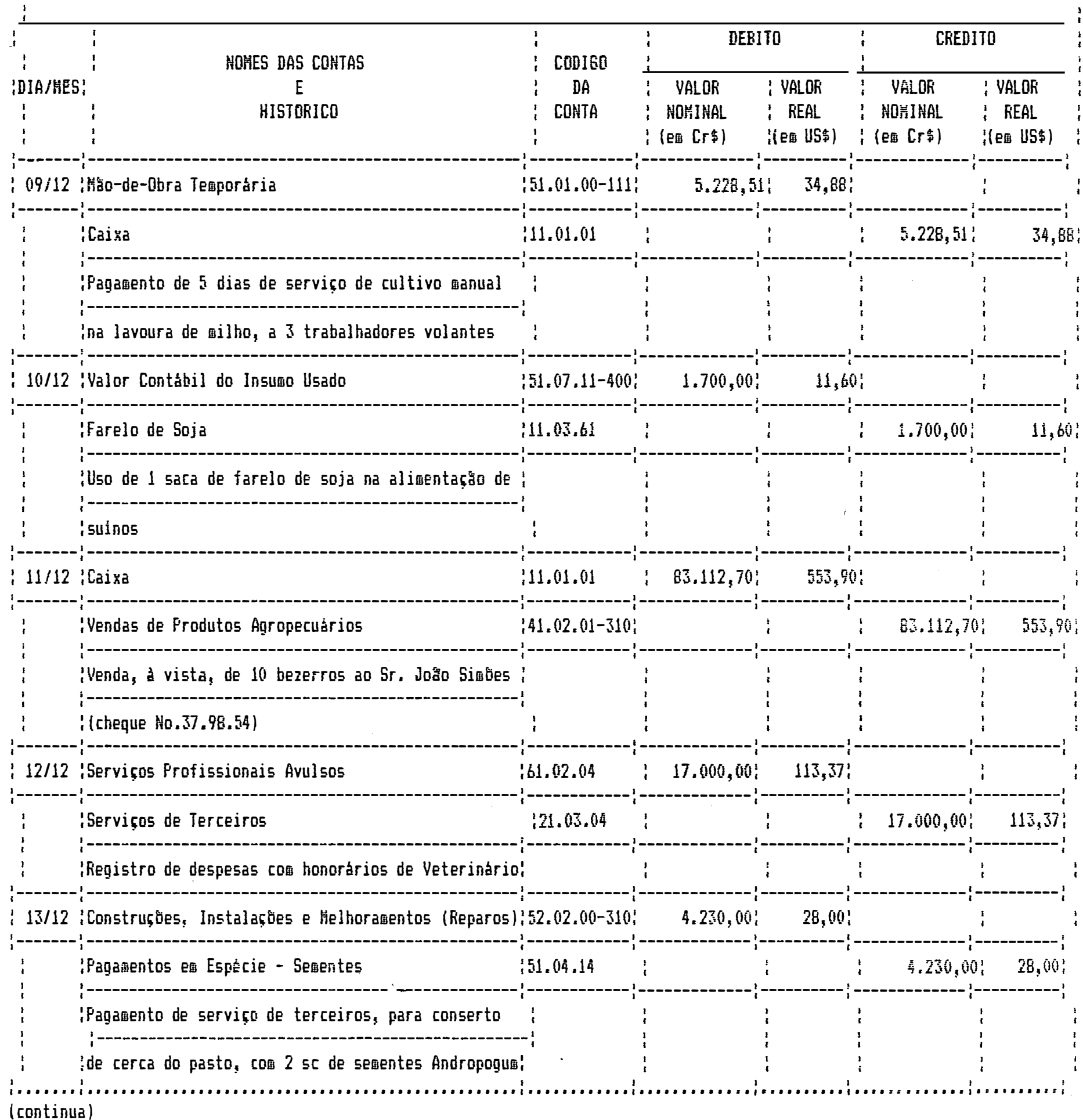


Tabela 29. Livro Diário (continuaşăo)

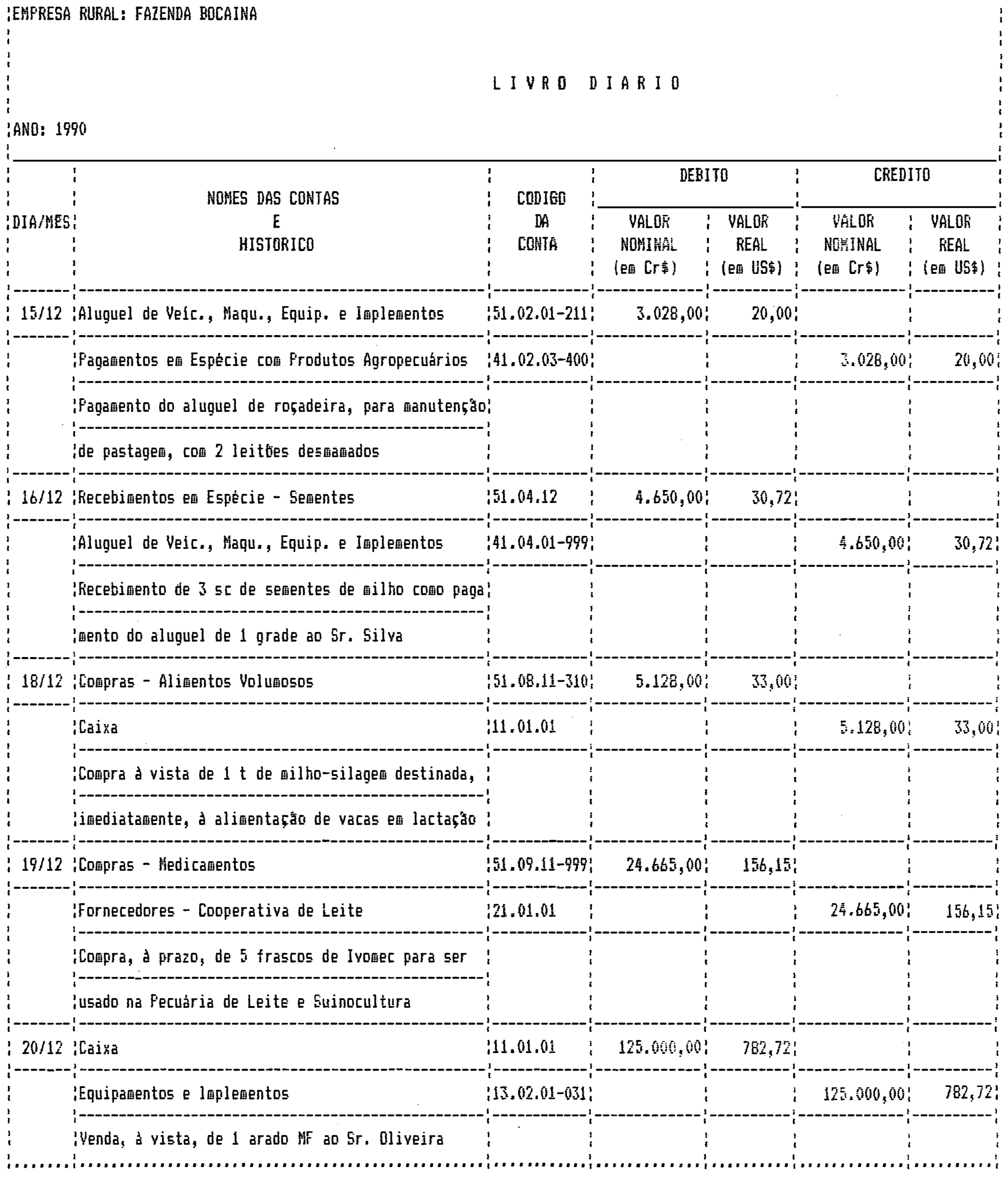

(continua) 
Tabela 29. Livro Diarrio (continuaçáa)

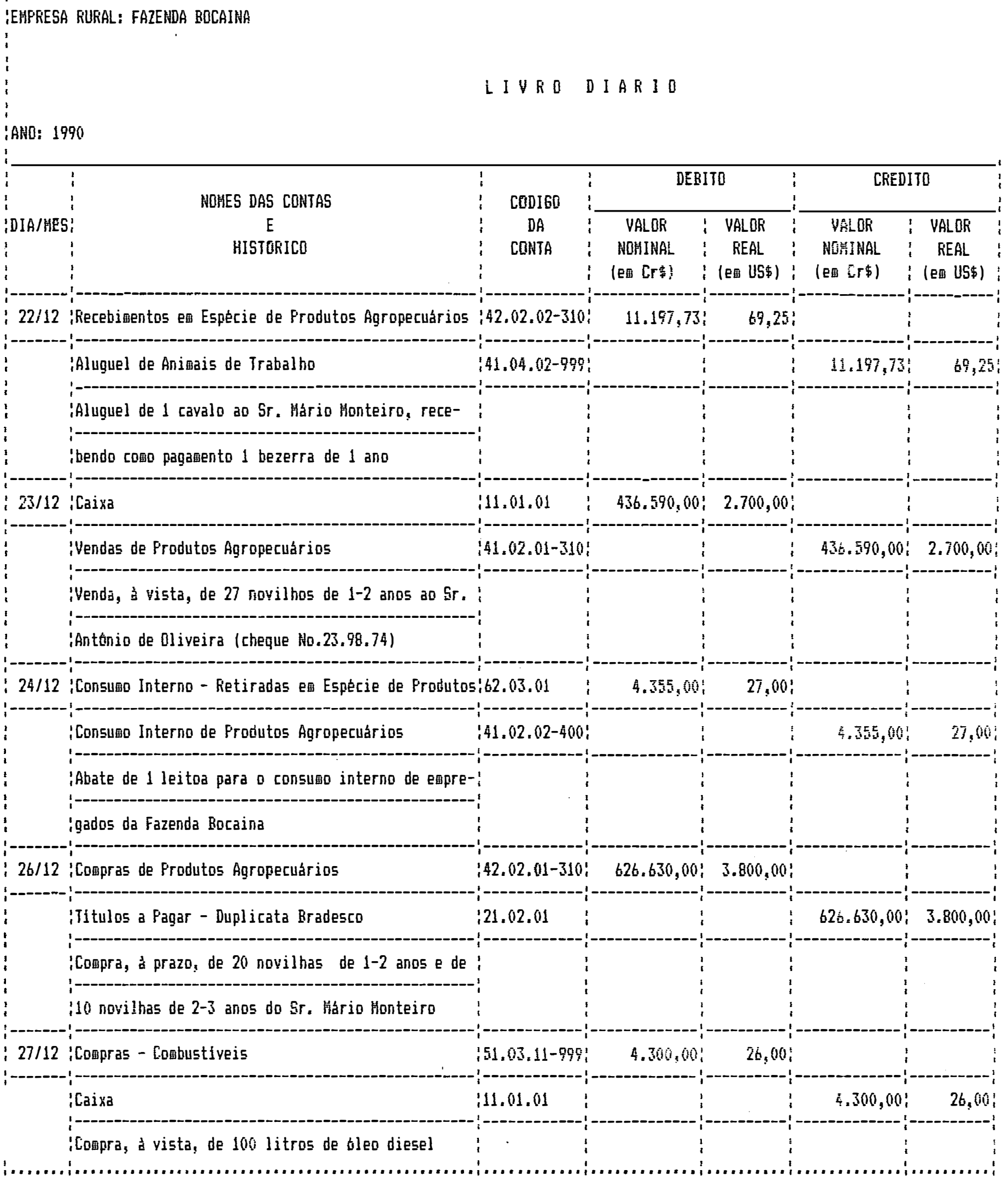

(continua) 
Tabela 29. Livro Diário (continuaçăa)

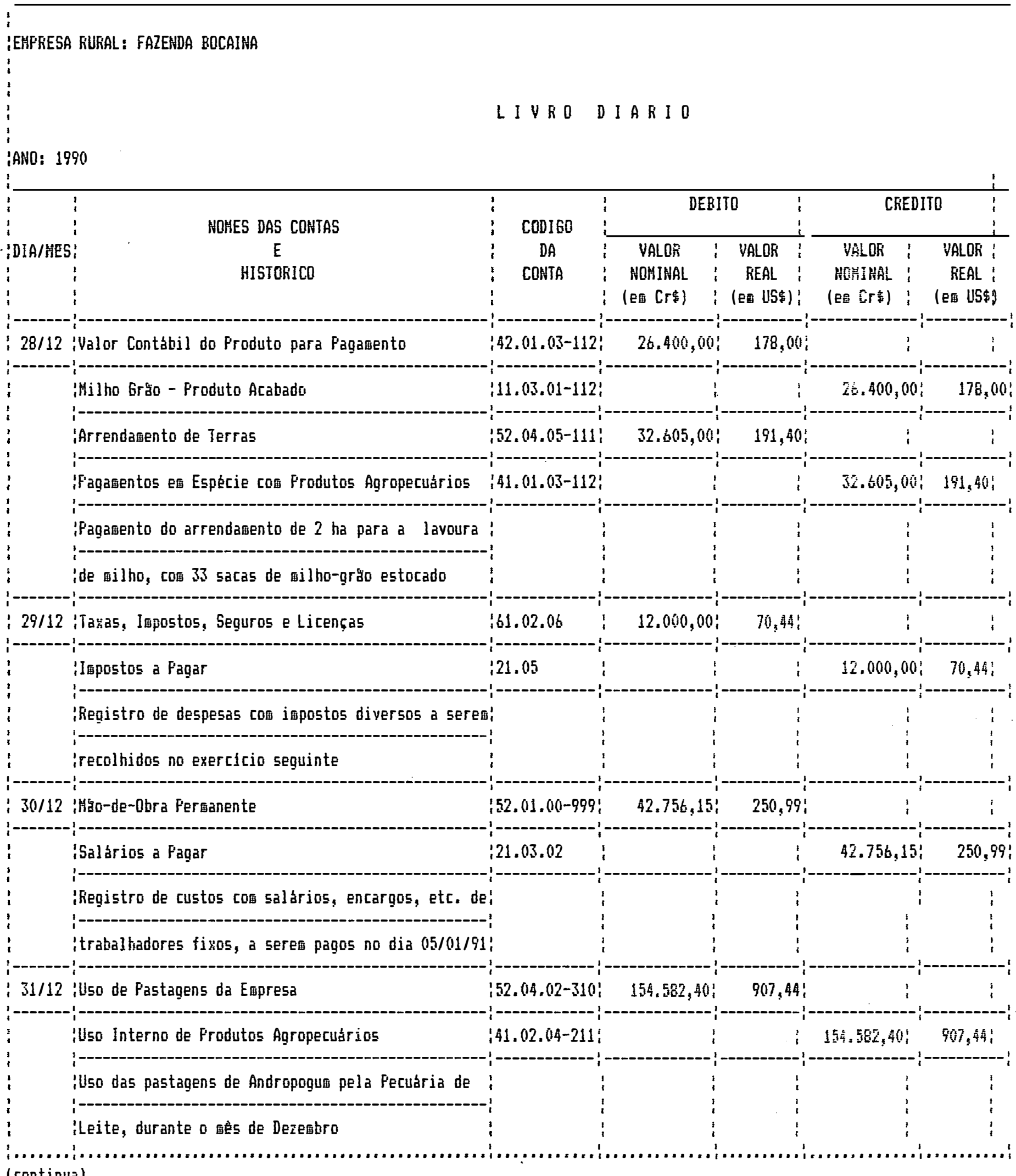

(continua) 
Tabela 29. Liyro Diário (continuaço)

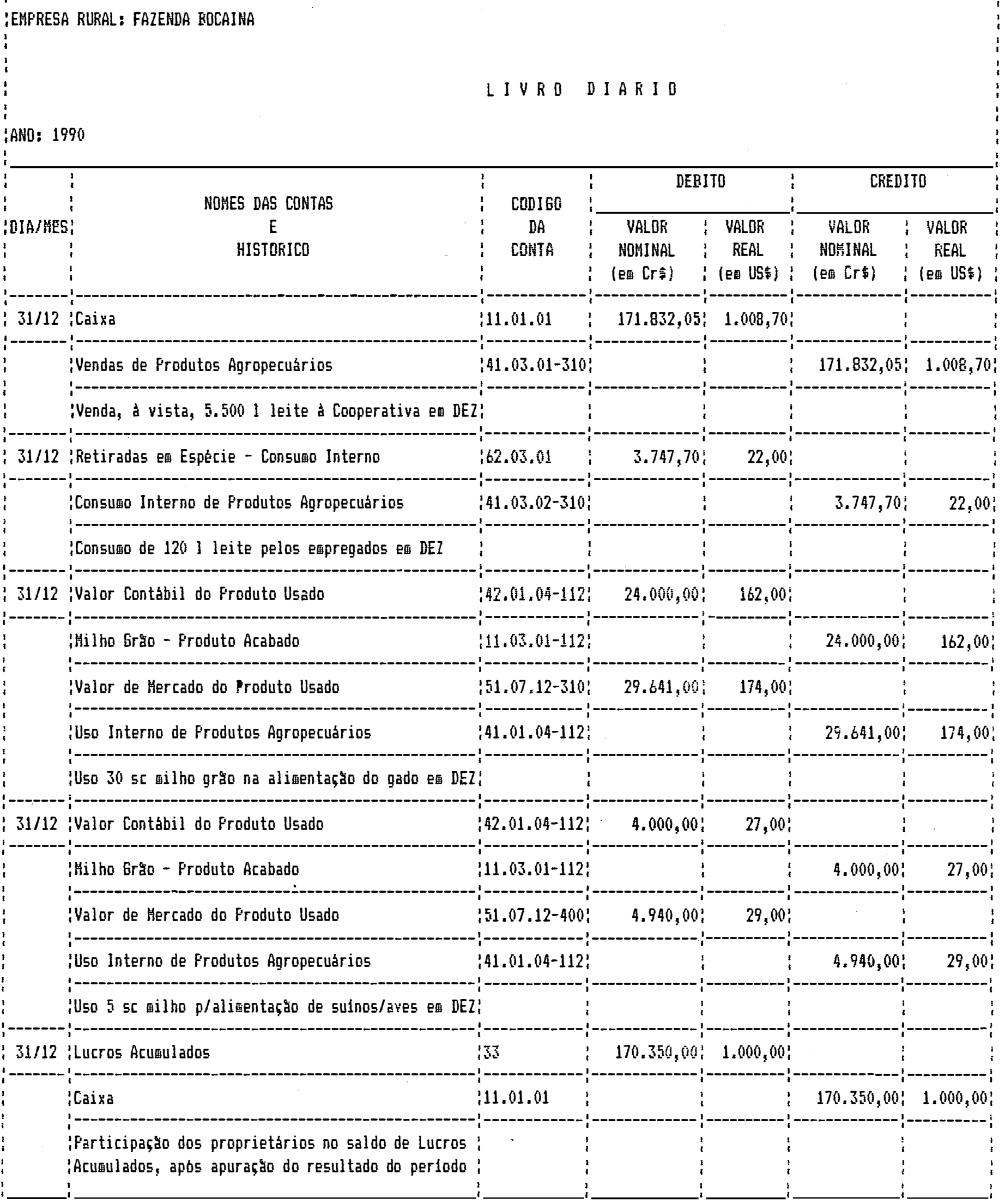


Tabela 30. Livro Caixa

IEMFRESA RUURAL: FAZENDA BOCAINA

i

LIVRORALSO

:ANO: 1990

i

INOME DA CONTA: CAIXA

i

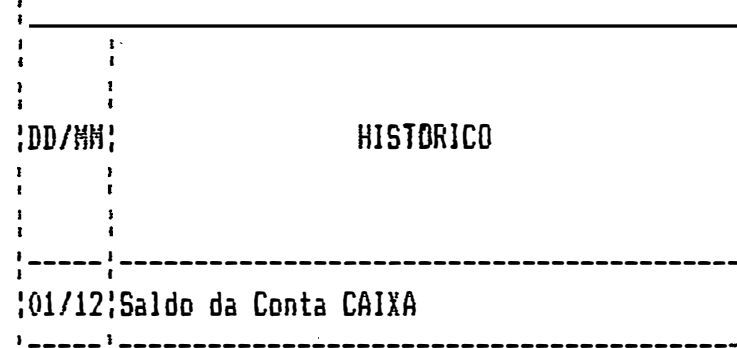

CODI60: 11.01 .01

:----:-

\begin{tabular}{|c|c|c|c|c|c|c|}
\hline \multicolumn{2}{|c|}{ DEBITO } & \multicolumn{2}{|c|}{ CREDITO } & \multicolumn{3}{|c|}{ SALDO } \\
\hline 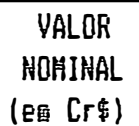 & $\begin{array}{l}\text { VALOR } \\
\text { REAL } \\
\text { (e两 US\$) }\end{array}$ & $\begin{array}{c}\text { VALOR } \\
\text { HOHINAL } \\
\text { (E画Cr站) }\end{array}$ & 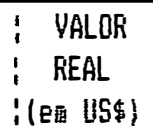 & in/ci & $\begin{array}{c}\text { VALOR } \\
\text { HOHIHAL } \\
\text { [E更 Cr\$! }\end{array}$ & $\begin{array}{l}\text { YALOR } \\
\text { KEAL } \\
\text { (E⿱一⿴⿻儿口一由) US\$) }\end{array}$ \\
\hline
\end{tabular}

:01/12:Venda, à vista, de 20 sacas de wilho-grăo

: ipara o Sr. Antênio de Oliveira

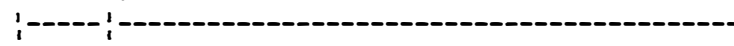

:06/12! Venda, à vista, de 3 dúzias de ovos à Coo-!

i $:$ iperativa de Leite

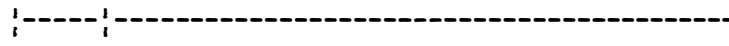

:(0B/12!Fagamento antecipado do aluguel de 1 wotor:

: Eelétrico ao Sr. Jogo Si

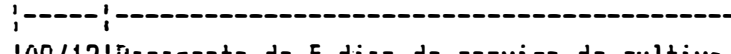

:09/12:Fagaento de 5 dias de serviço de cultiva

\section{ina lavoura de filho, a 3 trabalhadores}

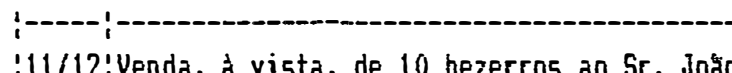

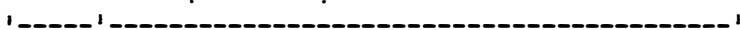

i isimbes

:----: i-

¿18/12'Coopra, à vista, de $1 \mathrm{t}$ de ailho-silager

: ip/ alimentaçato imediata de vacas lactaçato

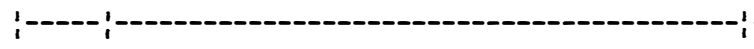

:20/12:Venda, à vista, de 1 arado Hassey Ferguson:

:23/12! Venda, a vista, de 27 novilhes 1-2 anos ao!

125. $000,00 ! \quad 782,72 !$

$83.112,70 ! \quad 553,90 !$

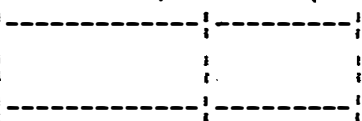

$16.492,00 \% 112,00 \%$

151,$78 ; \quad 1,02 ;$

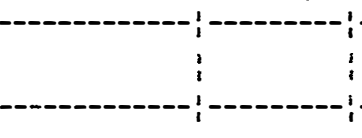

(1)
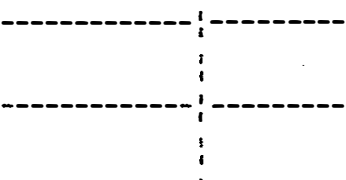

$3.000,00$

:---

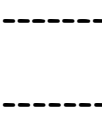

\section{$5.228,51:$}

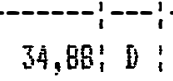

$18.415,27 ! 126,09:$

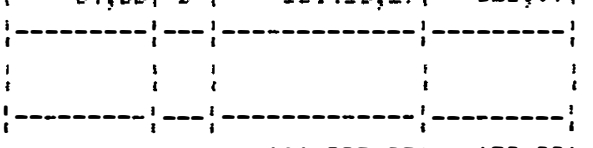

$\begin{array}{c:c:c}-10 & 101.527,97 ! & 679,99:\end{array}$

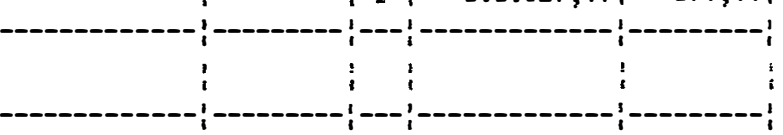

\section{$5.125,00: \quad 33,00: 0: \quad 96.399,97 \div \quad 646,97 \%$}

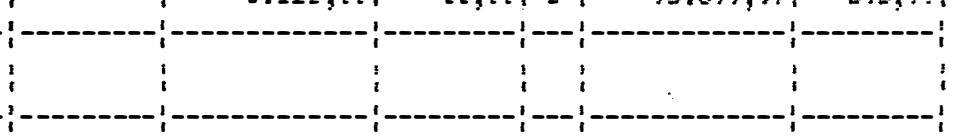

$436.590,00 \div 2.700,00 !$

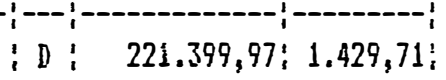

!'---! -------------!--------!

id: $657.989,97: 4.129,71:$

iSr. Anténio de 0liveira

! 1 :

(continua) 
Tabela 30. Livro Caixa (continuaça)

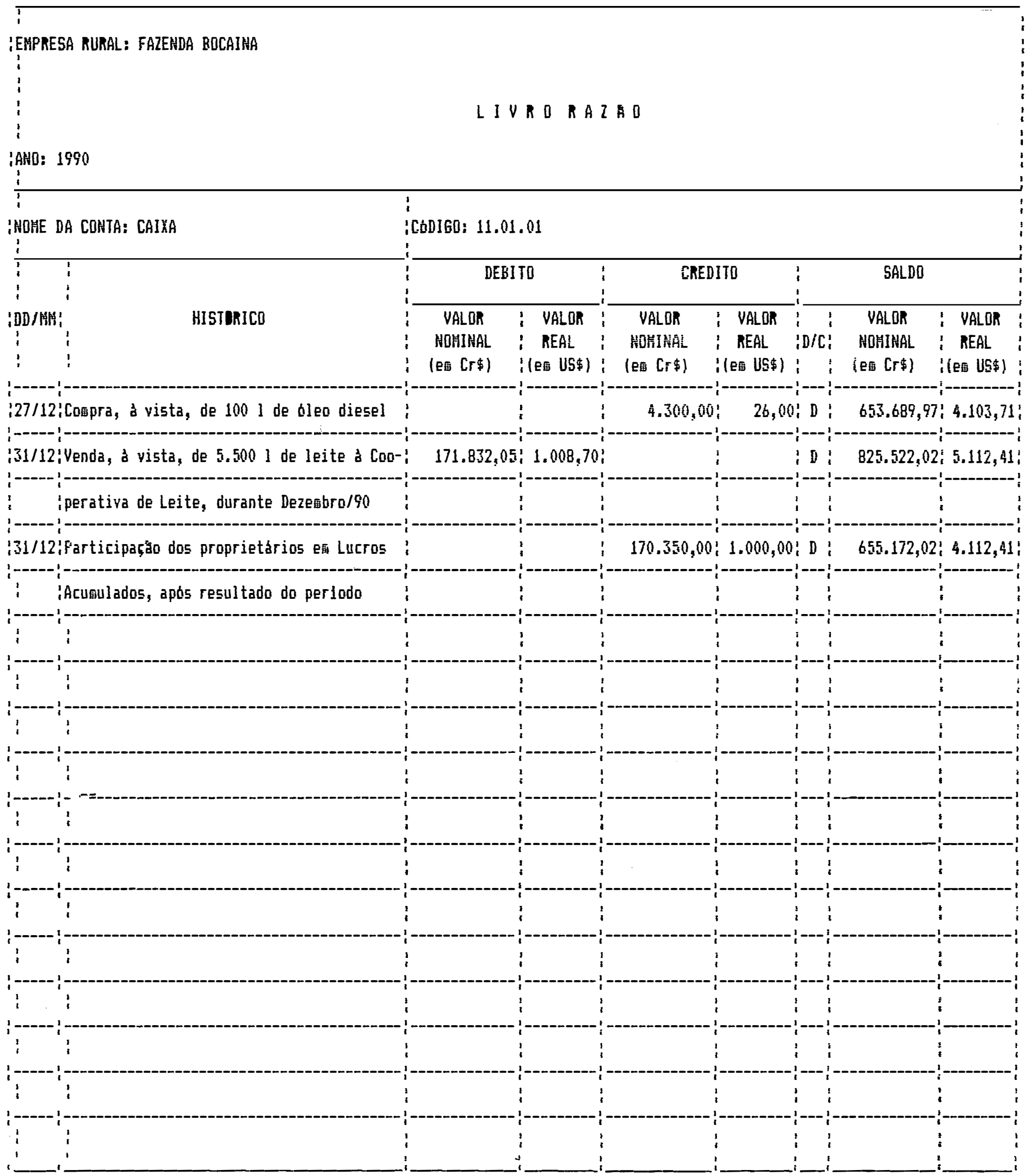


Figura 6. Transcriçóes nos Razonetes

\section{CONTABILIZAÇAD EH Crs}

DIA: $01 / 12 / 90$

$\frac{42.01 .01-112}{(a) 16.000,00 !}$

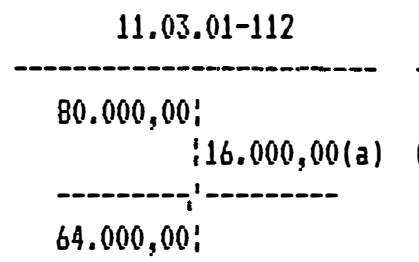

\begin{tabular}{cc}
11.01 .01 & $41.01 .01-112$ \\
\hline $\begin{array}{c}10.000,00 ! \\
\text { (b) } 16.492,00 !\end{array}$ & $\vdots$ \\
\hline $26.492,00 !$ & $\vdots$
\end{tabular}

DIA: $03 / 12 / 90$

DIA: $06 / 12 / 90$

\begin{tabular}{c}
11.03 .31 \\
\hline $3.000,00 !$ \\
\hline (c) $3.844,00 !$ \\
\hdashline $6.844,00 !$
\end{tabular}

$\frac{21.01 .01}{\vdots}$

\begin{tabular}{l}
11.01 .01 \\
\hline $26.492,00 !$ \\
$(00) 151,78 !$ \\
\hline $26.643,78 !$
\end{tabular}

$\frac{41.03 .01-400}{\vdots} i^{i}$

DIA: $08 / 12 / 90$

DIA: $09 / 12 / 90$

(e)3.000,00!

\begin{tabular}{c}
11.01 .01 \\
\hline $26.643,78 !$ \\
\hline $23.000,00(e)$ \\
\hdashline $3.643,78 !$
\end{tabular}

(f) $5.228,51 ;$

11.01 .01

$23.643,78:$

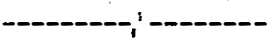

$18.415,27 !$

DIA: $10 / 12 / 90$

DIA: $11 / 12 / 90$

\begin{tabular}{r}
$51.07 .11-400$ \\
\hline$(9) 1.700,00 !$ \\
$\vdots$
\end{tabular}

\begin{tabular}{c}
11.03 .61 \\
\hline $34.000,00 !$ \\
\hline $32.300,00 !$
\end{tabular}

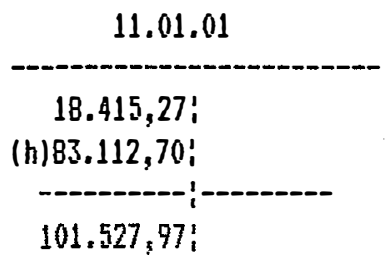

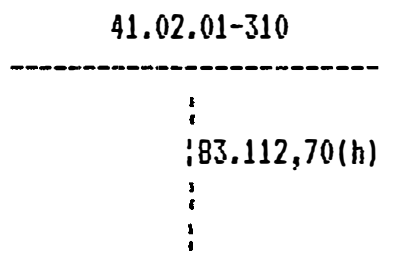

DIA: $12 / 12 / 90$

DIA: $13 / 12 / 90$

(i) $17.000,00 \vdots$

21.03 .04
$\vdots$
$\vdots$

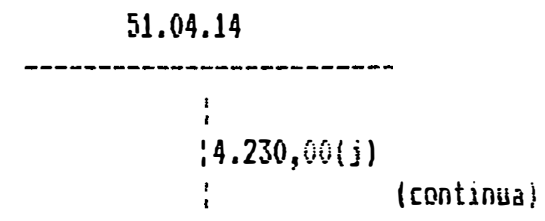


Figura 6. Transcriçb̆es nos Razonetes - ex Cr\$ (continuaçăo)

DIA: $15 / 12 / 90$

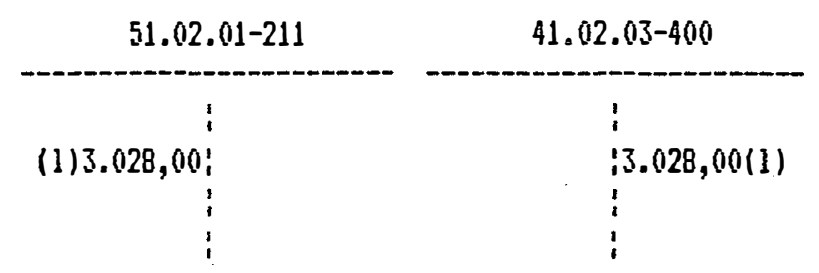

DIA: $18 / 12 / 90$
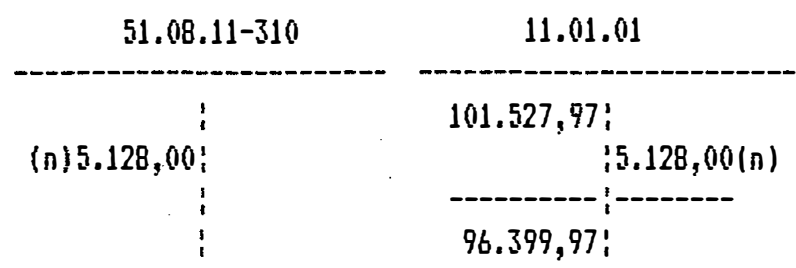

DIA: $20 / 12 / 90$

\begin{tabular}{c}
11.01 .01 \\
\hline $96.399,97 !$ \\
\hline $221.399,97 !$
\end{tabular}

DIA: $23 / 12 / 90$

\begin{tabular}{c}
11.01 .01 \\
\hline $221.399,97 !$ \\
\hline $657.989,97 !$
\end{tabular}

\begin{tabular}{c}
$41.02 .01-310$ \\
\hdashline$: 83.112,70$ \\
\hdashline $56.590,00(r)$ \\
\hdashline $519.702,70$
\end{tabular}

DIA: $26 / 12 / 90$
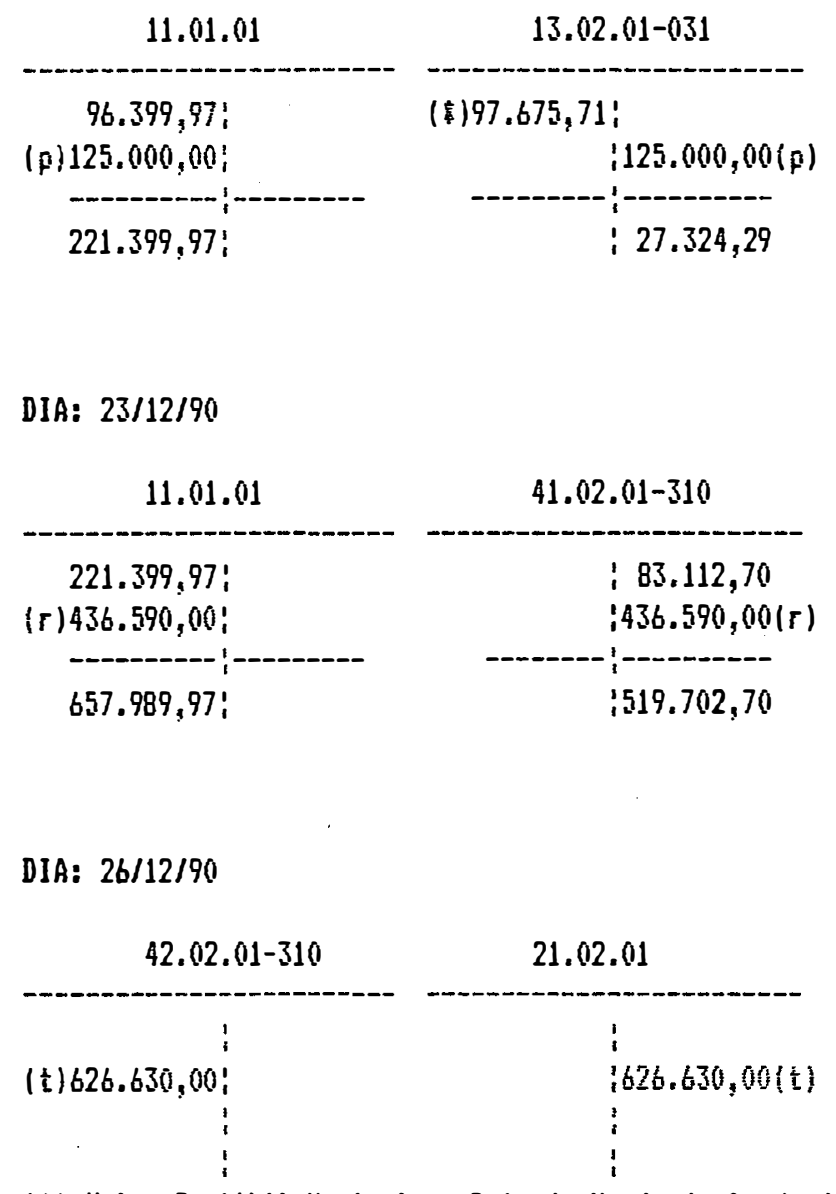
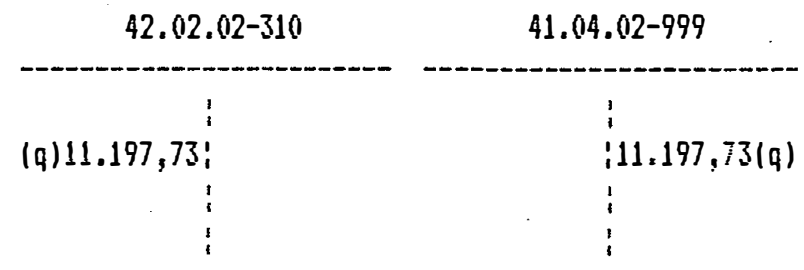

DIA: $24 / 12 / 90$

\begin{tabular}{rc}
62.03 .01 & $41.02 .02-400$ \\
\hline$\vdots$ & $\vdots$ \\
$\vdots$ & $\vdots 4.355,00151$ \\
$\vdots$ & $\vdots$
\end{tabular}

DIA: $27 / 12 / 90$

DIA: $16 / 12 / 90$

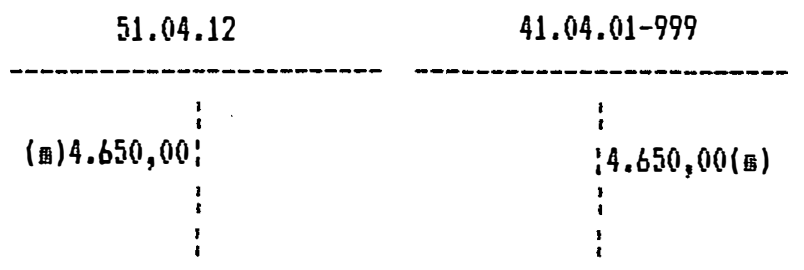

DIA: $19 / 12 / 90$

\begin{tabular}{cc}
$51.09 .11-999$ & 21.01 .01 \\
\hline$\vdots$ & $\vdots 3.844,00$ \\
$(0) 24.665,00 !$ & $-24.665,00(0)$ \\
$\vdots$ & $28.509,00$
\end{tabular}

DIA: $22 / 12 / 90$

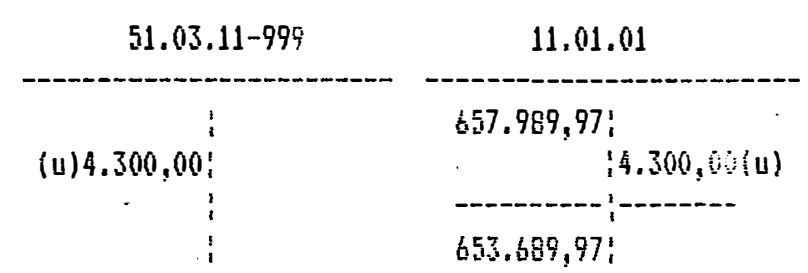

icontinua! 
Figura 6. Transcriçties nos Razonetes - en Cr\$ (continuaçáa)

DIA: $28 / 12 / 90$

\begin{tabular}{|c|c|c|c|}
\hline $42.01 .03-112$ & $11.03 .01-112$ & $52.04 .05-111$ & $41.01 .03-112$ \\
\hline & $64.000,00 !$ & ! & $:$ \\
\hline$(v) 26.400,00 i$ & $: 26.400,00(y)$ & $(x) 32.605,00 !$ & $32.605,00(x)$ \\
\hline 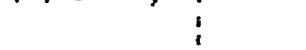 & - & i & : \\
\hline i & $37.600,00 i$ & i & ; \\
\hline
\end{tabular}

DIA: $29 / 12 / 90$

$\frac{61.02 .06}{(2) 12.000,00 !}$

DIA: $31 / 12 / 90$

$52.04 .02-310$

(เ) $154.582,40 !$

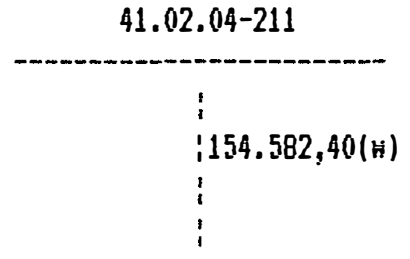

DIA: $30 / 12 / 90$

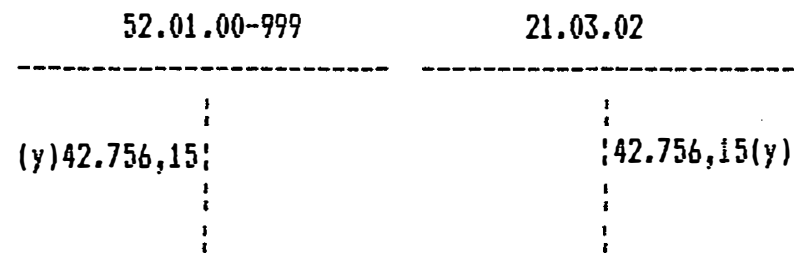

DIA: $31 / 12 / 90$

\begin{tabular}{cc}
11.01 .01 & $41.03 .01-310$ \\
\hline $653.689,97$ & $\vdots$ \\
\hline (k) $171.832,05$ & $\vdots 171.832,05(k)$ \\
\hdashline $825.522,02 !$ & $\vdots$
\end{tabular}

DIA: $31 / 12 / 90$

\begin{tabular}{cc}
62.03 .01 & $41.03 .02-310$ \\
\hline $4.355,00 !$ & $\vdots$ \\
\hline$(a) 3.747,70 !$ & $\vdots$ \\
\hdashline $8.102,70 !$ & $\vdots$
\end{tabular}

DIA: $31 / 12 / 90$

\begin{tabular}{cccc}
$42.01 .04-112$ & $11.03 .01-112$ & $51.07 .12-310$ & $41.01 .04-112$ \\
\hline$\vdots$ & $37.600,00 !$ & $\vdots$ & $\vdots$ \\
(b) $24.000,00 !$ & $24.000,00(b)$ & $(c) 29.641,00 !$ & $\vdots$
\end{tabular}


Figura 6. Transcriçûes nos hiazonetes - ex Cr $\$$ (continuaçå)

DIA: $31 / 12 / 90$

\begin{tabular}{|c|c|c|c|}
\hline $42.01 .04-112$ & $11.03 .01-112$ & $51.07 .12-400$ & $41.01 .04-112$ \\
\hline (b) $4.000,00 !$ & $\begin{array}{l}13.600,00 ! \\
\vdots 4.000,00(\mathrm{~b})\end{array}$ & (c) $4.940,00 !$ & $4.940,00(c)$ \\
\hline ! & $9.600,00 !$ & ! & $i$ \\
\hline
\end{tabular}

DIA: $31 / 12 / 90$

\begin{tabular}{|c|c|c|}
\hline & 33 & 11.01 .01 \\
\hline (d) $170.350,00$ & $\vdots(1)$ & $\begin{array}{l}825.522,02: \\
: 170.350,0010\end{array}$ \\
\hline & $(\$)$ & $655.172,02 !$ \\
\hline
\end{tabular}

(1) Considerar os saldos de Lucros Acu甽lados somente na contabilizaçåo e- US\$

\section{CONTABILIZAÇAO EM US\$}

DIA: $01 / 12 / 90$

\begin{tabular}{cccc}
$42.01 .01-112$ & $11.03 .01-112$ & $11.01,01$ & $41.01 .01-112$ \\
\hline$\vdots$ & $540,00 !$ & $67,96 !$ & $\vdots$ \\
$(a) 108,00 !$ & $2108,00(a)$ & $(b) 112,00 !$ & $\vdots$ \\
$\vdots$ & $432,00 !$ & $179,96 !$ & $\vdots$
\end{tabular}

DIA: $03 / 12 / 90$

\begin{tabular}{cc}
11.03 .31 & 21.01 .01 \\
\hline $20,40 !$ & $\vdots$ \\
$(c) 26,00 !$ & $\vdots$ \\
\hdashline $46,40 !$ & $\vdots$
\end{tabular}

D]Á: $08 / 12 / 90$

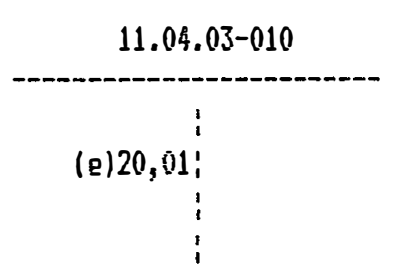

\begin{tabular}{c}
11.01 .01 \\
\hline $180,98 !$ \\
\hdashline $20,01(e)$ \\
\hdashline $160,97 !$
\end{tabular}

DIA: $06 / 12 / 90$

\begin{tabular}{cc}
11.01 .01 & $41.03 .01-500$ \\
\hline $179,96 !$ & $\vdots$ \\
\hline$(d) 1,02 !$ & $\vdots$ \\
\hdashline $180,98 !$ & $\vdots$
\end{tabular}

DIA: $09 / 12 / 90$

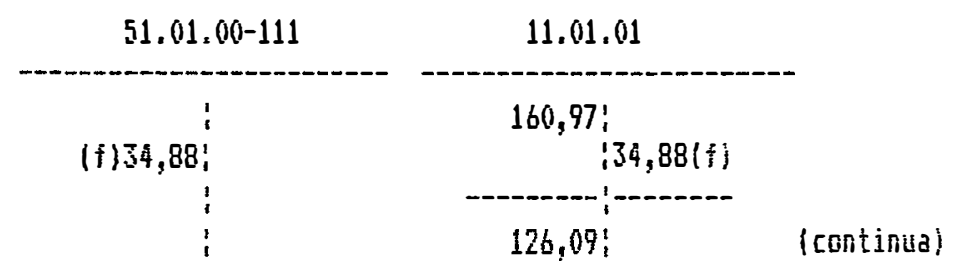


Figura 6. Transcriçtes nos Razonetes - efi US\$ (continuaçăo)

DIA: $10 / 12 / 90$

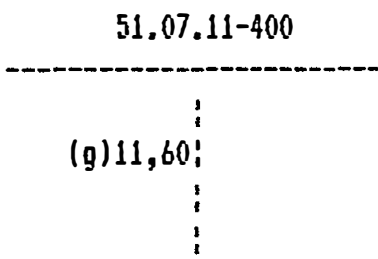

DIA: $11 / 12 / 90$

\begin{tabular}{cc}
11.01 .01 & $41.02 .01-310$ \\
\hline $126,09 !$ & $\vdots$ \\
\hline (h) $553,90 !$ & $\vdots 553,90(\mathrm{~h})$ \\
\hline $679,99 !$ & $\vdots$
\end{tabular}

DIA: $12 / 12 / 90$

\begin{tabular}{rc}
61.02 .04 & 21.03 .04 \\
\hline$\vdots$ & $\vdots$ \\
(i) $113,37 !$ & $\vdots$
\end{tabular}

\begin{tabular}{cc}
$52.02 .00-310$ & 51.04 .14 \\
\hline$\vdots$ & $\vdots$ \\
$\vdots$ & $\vdots 28,00(j)$
\end{tabular}

DIA: $15 / 12 / 90$

(1)20,00!

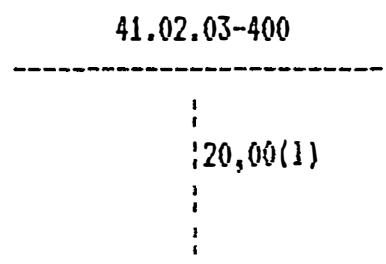

DIA: $18 / 12 / 90$
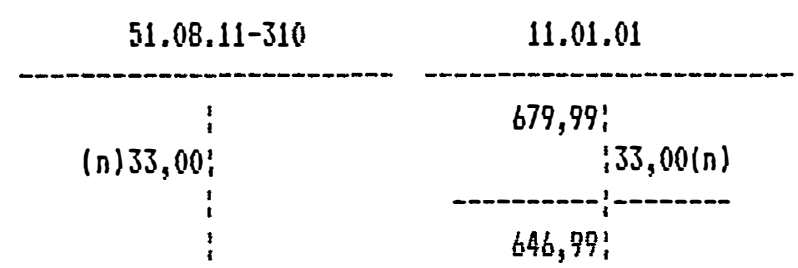

DIA: $20 / 12 / 90$
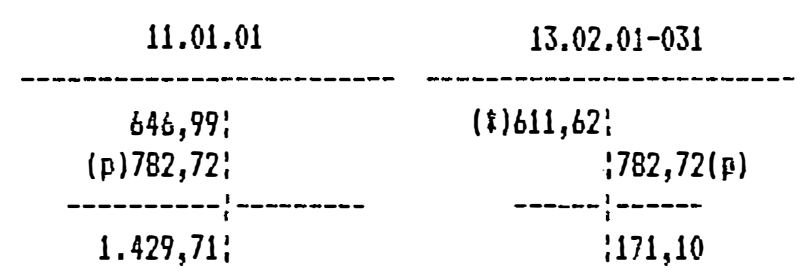

DIA: $16 / 12 / 90$

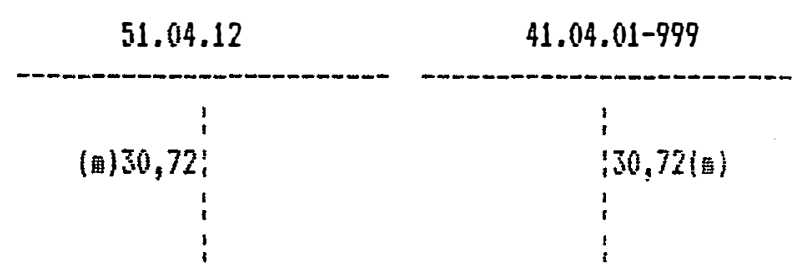

DIA: $19 / 12 / 90$

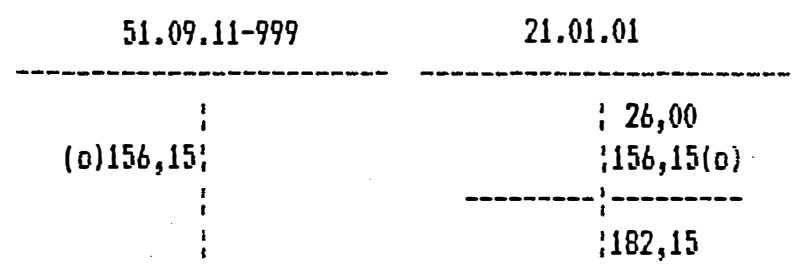

DIA: $22 / 12 / 90$

\begin{tabular}{cc}
$42.02 .02-310$ & $41.04 .02-999$ \\
\hline$\vdots$ & $\vdots$ \\
$\vdots$ & $\vdots$
\end{tabular}

(continius)

(5) Valor Contábi] Keal na Data da Venda do Arado (Código 31.01.02-01) 


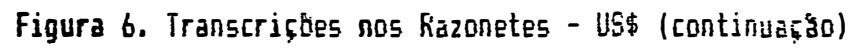

DIA: $23 / 12 / 90$

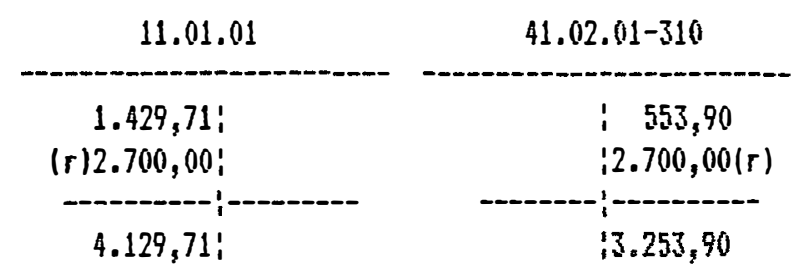

DIA: $26 / 12 / 90$
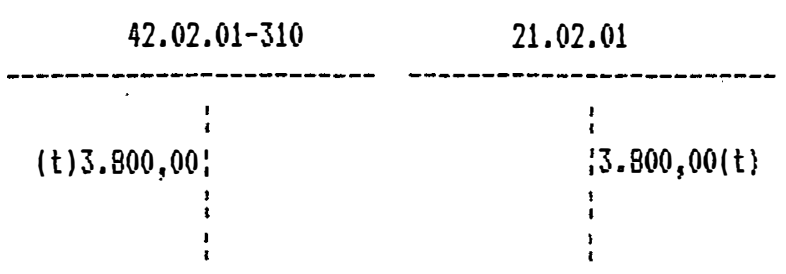

DIA: $28 / 12 / 90$

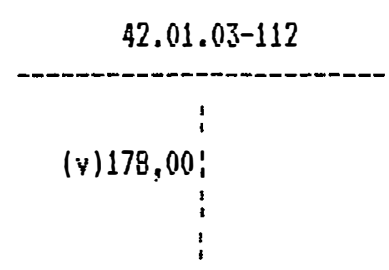

\begin{tabular}{c}
$11.03 .01-112$ \\
\hdashline $432,00 !$ \\
\hdashline $178,00(v)$ \\
\hdashline $254,00 !$
\end{tabular}

DIA: $29 / 12 / 90$

\begin{tabular}{r}
61.02 .06 \\
\hline$\vdots$ \\
$\vdots$
\end{tabular}

\begin{tabular}{c}
21.05 \\
\hdashline \\
$\vdots$ \\
$\vdots$
\end{tabular}

DIA: $31 / 12 / 90$

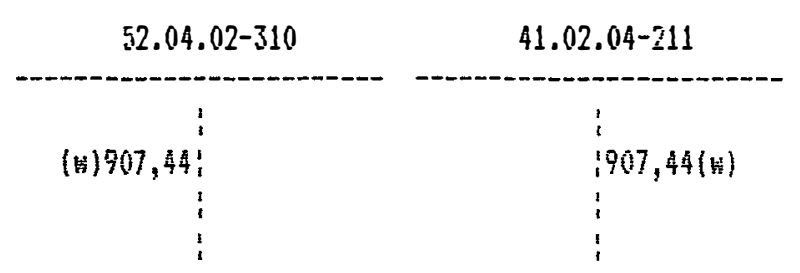

DIA: $24 / 12 / 90$

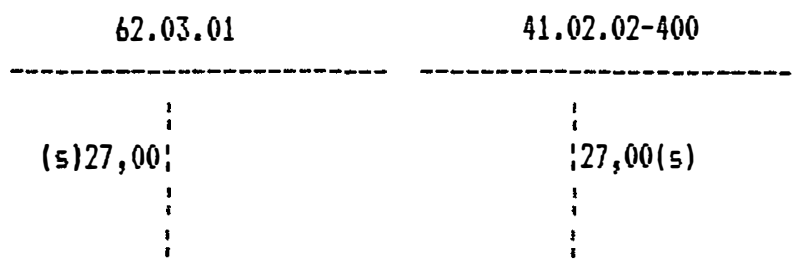

DIA: $27 / 12 / 90$

\begin{tabular}{cc}
$51.03 .11-999$ & 11.01 .01 \\
\hline $\begin{array}{c}\text { (u) } 26,00 \\
\vdots\end{array}$ & $4.129,71 !$ \\
\hdashline & $4.103,71 !$
\end{tabular}

DIA: $30 / 12 / 90$

\begin{tabular}{cc}
$52.01 .00-999$ & 21.03 .02 \\
\hline$\vdots$ & $\vdots$ \\
\hline$\vdots$ & $\vdots 250,99(y)$ \\
$\vdots$ & $\vdots$
\end{tabular}

DIA: $31 / 12 / 90$

\begin{tabular}{cc}
11.01 .01 & $41.01 .01-310$ \\
\hline $4.103,71 !$ & $\vdots$ \\
$(k) 1.008,70 !$ & $\vdots$ \\
\hdashline $5.112,41 !$ & $\vdots$
\end{tabular}

(continus) 


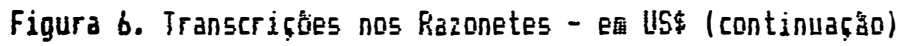

DIA: $31 / 12 / 90$

\begin{tabular}{cc}
62.03 .01 & $41.03 .02-310$ \\
\hline $27,00 !$ & $\vdots$ \\
\hline $12122,00 !$ & $\vdots$
\end{tabular}

DIA: $31 / 12 / 90$

\begin{tabular}{cccc}
$42.01 .04-112$ & $11.03 .01-112$ & $51.07 .12-310$ & $41.01 .04-112$ \\
\hline 1 & $25,162,00 !$ & $\vdots$ & $\vdots$ \\
$\vdots$ & $-162,00(b)$ & $(c) 174,00 !$ & $\vdots$
\end{tabular}

DIA: $31 / 12 / 90$

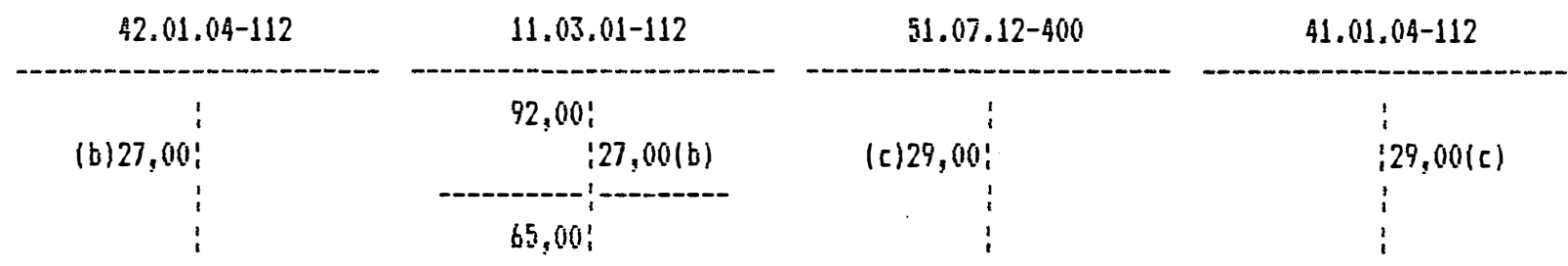

DIA: $31 / 12 / 90$

\begin{tabular}{cc}
33 & 11.01 .01 \\
\hline (d) $1.000,00 !$ & $5.112,41 !$ \\
\hdashline $133.383,22(1)$ & $\vdots 1.000,001 d 1$ \\
\hdashline $132.383,22$ & $4.112,41 !$
\end{tabular}

(1) Saldo de Lucros Acuinulados após apuraçąo do resultado do periodo. 
Tabela 31. Inventário Periódico

EMPFIESA FIULFAL: FAIENDA BOCAINA

DATA: 01/01/91

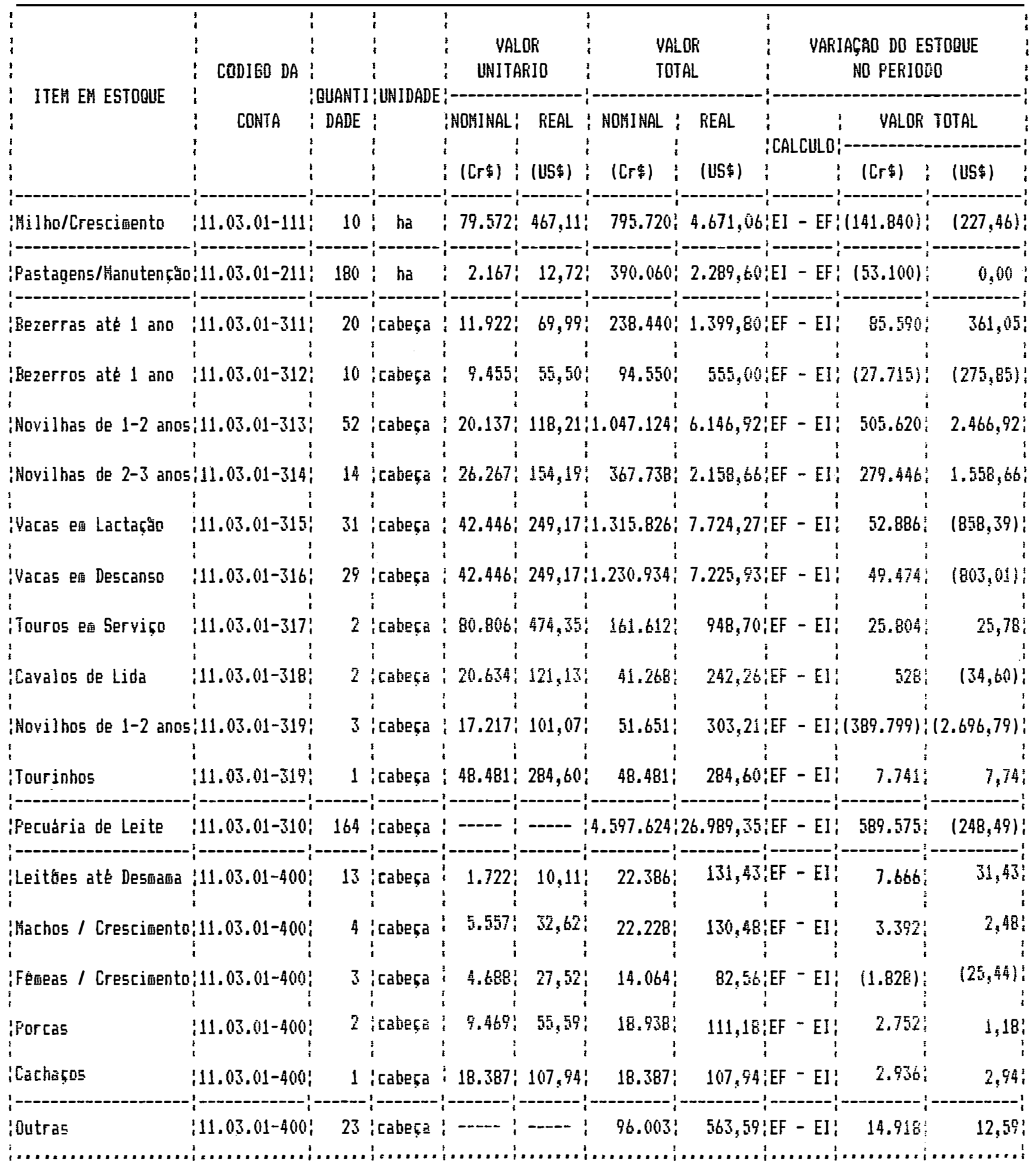

(continua) 
Tabela 31. Inventário Periodico (continuaçå)

EHFRESA RURRAL: FAIENDA BDCAINA

DATA: $01 / 01 / 91$

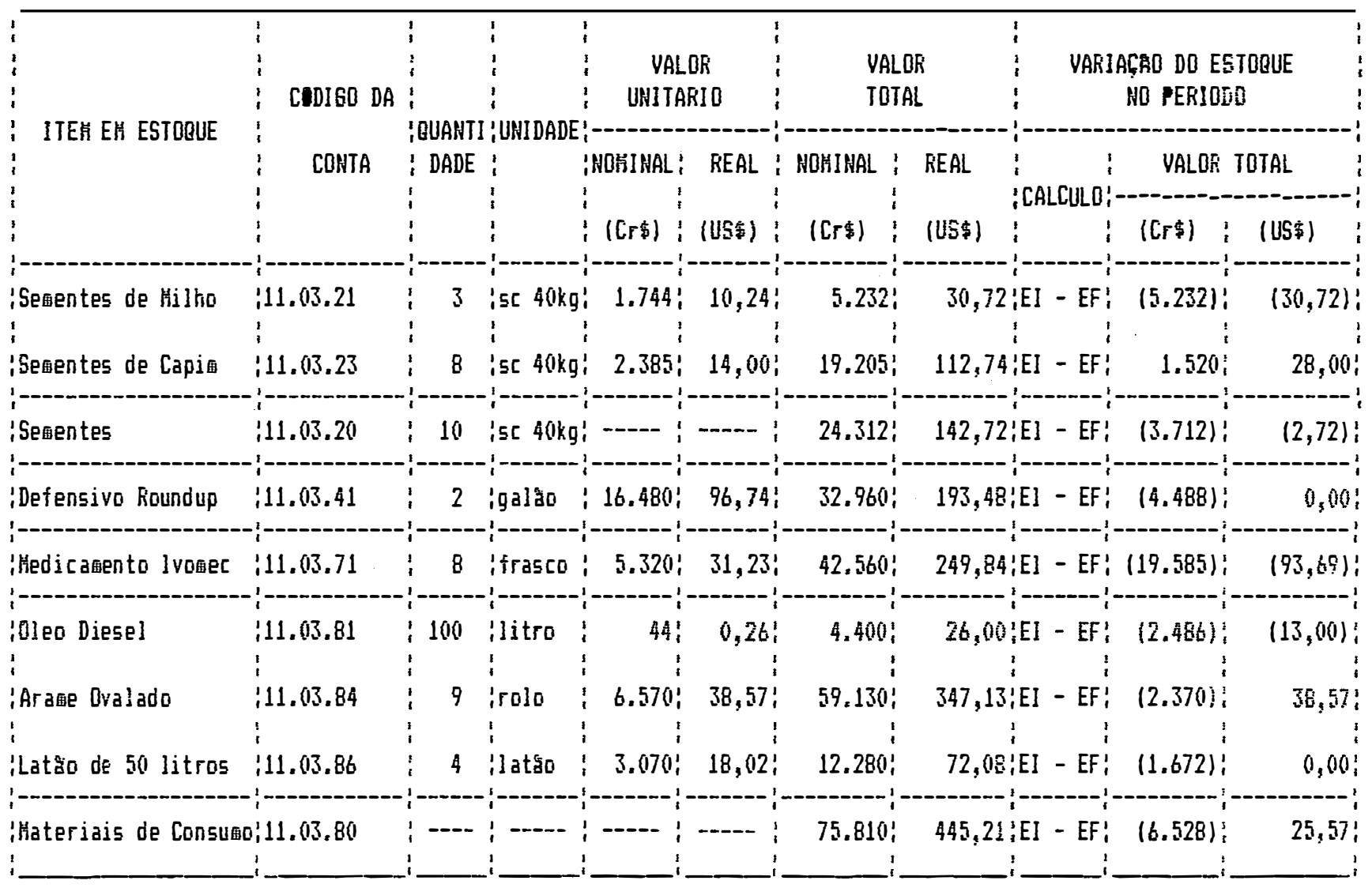

\section{Ajustes}

A Figura 7 apresenta os lancamentos de ajuste necessários à apuração dos resultados do período, de acordo com as fórmulas em destaque.

.7. Encerramento de Contas e Distribuicão dos Resultados

A Figura 8 ilustra o mecanismo de encerramento das contas de Receita, Ganho, Custo, Despesa e Perda e a determinacão dos resultados transferidos para a DRE. 
Figura 7. Ajustes

CONTAEILIZAÇA EH US\$

Inventário Periodico

- Hilho-6răo eq Crescimento

\begin{tabular}{cc}
$11.03 .01-111$ & $53.01 .01-111$ \\
\hline$(E J) 4,443,60 !$ & $\vdots$ \\
$(E]-E F) 227,46 !$ & $\vdots$ \\
\hdashline$-227,46(E)-E F)$ \\
$(E F) 4.671,06:$ & $\vdots$
\end{tabular}

- Pecuária de Leite (Animais)

\begin{tabular}{|c|c|}
\hline $11.03 .01-310$ & $41.02 .05-310$ \\
\hline $\begin{aligned} &(E I) 27.237,84 ! \\
&: 248,49(E F-E I)\end{aligned}$ & $(E F-E]) 248,49 !$ \\
\hline$(E F) 26.989,35$ & : \\
\hline
\end{tabular}

- Suinocultura (Outras)

\begin{tabular}{cc}
$11.03 .01-400$ & $41.02 .05-400$ \\
\hline $\begin{array}{c}\text { (E]) } 551,00 ! \\
\text { (EF-EJ) } 12,59 !\end{array}$ & $\vdots$ \\
\hdashline$(E F) 563,59 !$ & $\vdots$
\end{tabular}

- Senentes e Hudas

51.04 .15

\begin{tabular}{cc} 
(EI) $140,00 !$ & $\vdots$ \\
(EI-EF) $2,72:$ & $\vdots 2,72 i E I-E F)$ \\
\hdashline$(E F) 142,72 !$ & $\vdots$
\end{tabular}

Formula $(20): C P C A=E I+C C A P-E F=A E C A+C C A E$

$$
\begin{aligned}
A E C A & =E I-E F=-227,46 \\
\text { CCAP } & =227,46 \\
\therefore C P C A & =0
\end{aligned}
$$

Formula (22): VEP(de Anitrais) $=V+C]+P E+U+[(E F-E I)-C-R E]$

$$
\begin{aligned}
\text { VBP } & =3.253,90+0+0+0+[\mathrm{APr}] \\
\mathrm{APr} & =[(-248,49)-3.800,00-69,25 \mathrm{si}=-4.117,74 \\
\therefore \mathrm{VHP} & =-863,85
\end{aligned}
$$

Forrula (22): VHP $=V+C]+P E+U+[(E F-E])-C-R E]$

$$
\begin{aligned}
\text { VHP } & \left.=0+27,00+20,00 \div 0+\left[A P_{T}\right]\right] \\
A P P r & =[112,59]-0-0]=12,59 \\
\therefore \text { VHP } & =59,59
\end{aligned}
$$

Formula (24'): UI $=C+R E-V-P E+(E]-E F)$

$$
\begin{aligned}
U I & =0+30,72-0-28,00+(\text { AE }) \\
\text { AE } & =-2,72 \\
\therefore U I & =0
\end{aligned}
$$

(continua) 
Figura. 7. Ajustes - eq US\$ (continuaçgo)

\section{- Defensivos}

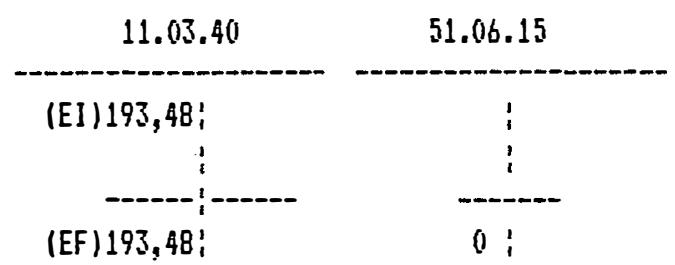

- Hedicamentos e Vacinas

\begin{tabular}{cc}
11.03 .70 & $51.09 .15-999$ \\
\hline$(E]) 156,15 !$ & $\vdots$ \\
$(E]-E F) 93,69 !$ & $\vdots 93,69(E]-E F)$ \\
\hdashline$(E F) 249,84:$ & $\vdots$
\end{tabular}

- Oleo Diesel

\begin{tabular}{cc}
11.03 .81 & $51.03 .15-999$ \\
\hline$(E]) 13,00 !$ & $\vdots$ \\
$(E]-E F) 13,00 !$ & $\vdots 13,00(E]-E F)$ \\
\hdashline $26,00 !$ & $\vdots$
\end{tabular}

- Arane Ovalado

\begin{tabular}{|c|c|}
\hline 11.03 .84 & $51.10 .15-310$ \\
\hline $\begin{array}{c}(E]) 385,70: \\
: 38,57(E]-E F)\end{array}$ & $(E]-E F) 38,57 !$ \\
\hline$(E F) 347,13 ;$ & i \\
\hline
\end{tabular}

- Latgo de 50 litros

\begin{tabular}{rr}
$11.03,86$ & 51.10 .15 \\
\hline (EI) 72,08 & $25,57 !$ \\
\hdashline (EF) $72,08:$ & $\vdots$ \\
\hdashline
\end{tabular}

Formula $\left.\left(24^{\prime}\right): U I=C+R E-V-P E+(E]-E F\right)$

$$
\begin{aligned}
U I & =0+0-0-0+(\mathrm{AE}) \\
\mathrm{AE} & =0 \\
\therefore U I & =0
\end{aligned}
$$

Formula $\left(24^{\circ}\right): U I=C+R E-V-P E+(E I-E F)$

$$
\begin{aligned}
U I & =156,15+0-0-0+(A E) \\
A E & =-93,69 \\
\therefore U I & =62,46
\end{aligned}
$$

Formula $\left.\left(24^{\circ}\right): U I=C+R E-V-P E+(E]-E F\right)$

$$
\begin{aligned}
U I & =26,00+0-0-0+(A E) \\
A E & =-13,00 \\
\therefore U I & =13,00
\end{aligned}
$$

Forfula $\left.\left(24^{\circ}\right): U I=C+R E-V-P E+(E]-E F\right)$

$$
\begin{aligned}
U I & =0+0-0-0+\{A E) \\
A E & =38,57 \\
\therefore U I & =38,57
\end{aligned}
$$

Formula (24'): UI $=[+R E-V-P E+(E]-E F)$

$$
\begin{aligned}
U I & =0+0-0-0+(A E) \\
A E & =0 \\
\therefore U I & =0
\end{aligned}
$$


Figura 7. Ajustes - eri US\$ (continuaģăa)

Alteraşotes de Preços Reais dos Estoques

- Milho-Grào - Produto Acabado

\begin{tabular}{cc}
$11.03 .01-112$ & $41.01 .06-112$ \\
\hline $65,00 !$ & $\vdots$ \\
$5,00 !$ & $\vdots$ \\
\hdashline $70,00 !$ & $\vdots$
\end{tabular}

Forrula (25): $\mathrm{VBP}=V+C I+P E+U+P R+A R-$ $-(V C P V-V C P C-V C P P-V C P V-V C P P E)$ $V B P=112,0+0+191,4+203,0+0+5,0-$ $-(108,0-0-178,0-189,0-0)$

$\therefore V B P=511,4-(475,0)=36,4$

Ganhos nas Vendas de Bens de Capital (Arado-Cadigo 31.01.02-01)

\begin{tabular}{cc}
$13.02 .01-031$ & 43.01 \\
\hline $611,62 !$ & $\vdots$ \\
$: 782,72$ & $\vdots$ \\
\hdashline$(0) 171,10: 171,10$ & $\vdots$ \\
\hdashline $0 !$ & $\vdots$
\end{tabular}

Depreciaçăo de Ativo Itobilizado Inter mediário e Fixo

\begin{tabular}{cc}
$52.04 .00-999$ & 13.02 .03 \\
\hline $1.071,46 !$ & $\vdots 1.071,46$ \\
$\vdots$ & $\vdots$
\end{tabular}

Reavaliaço de Ativo Itobilizado Fixo (Terras)

\begin{tabular}{cc}
$13.02 .02-010$ & 32.02 \\
\hline $101.010,00 !$ & $\vdots$ \\
$(r) 990,00 !$ & $\vdots$ \\
\hdashline $102,000,00 !$ & $\vdots$
\end{tabular}


Figura 7. Ajustes - eli US\$ (continuaça)

Ganhos nas Obrigaçtes Operacionais

- Contabilizaçăo eq Cr\$ . Contabilizaça e日 US\$

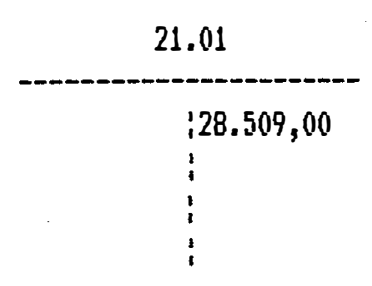

21.02

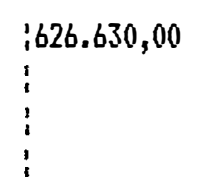

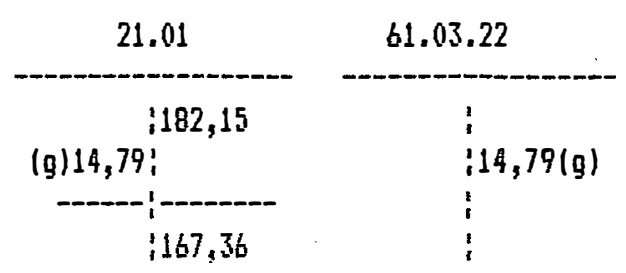

61.03 .22

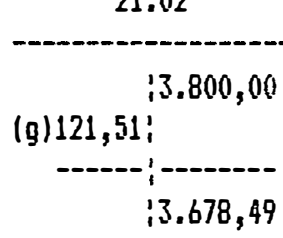

Fbr畹a (18): gro $(t)=\operatorname{otrf}(t)-[\operatorname{otfn}(t) /$ def $(t)]$

$$
\text { gro }(t)=182,15-[28.509,00 / 170,35]
$$$$
\text { gro }(t)=182,15-167,36
$$$$
\text { gro }(t)=14,79
$$

gro $(t)=3.800,00-[626.630,00 / 170,35]$

gro $(t)=3.800,00-3.678,49$

gro $(t)=121,51$

Perdas nos Itens Monetários

- Contabilizaça e Cr\$ . Contabilizaçăo en US\$

\begin{tabular}{c}
11.01 .01 \\
\hline $655.172,02 !$ \\
$\vdots$
\end{tabular}

Formula (17): $\operatorname{prc}(t)=\operatorname{cfr}(t)-[\operatorname{cfn}(t) / \operatorname{def}(t)]$

$$
\begin{aligned}
& \operatorname{prc}(t)=4.112,41-[655.172,02 / 170,35] \\
& \operatorname{prc}(t)=4.112,41-3.846,03 \\
& \operatorname{prc}(t)=266,38
\end{aligned}
$$

Ganhos nos Itens Honetários

- Contabilizaça en Cr\$ . Contabilizaçăo en US\$

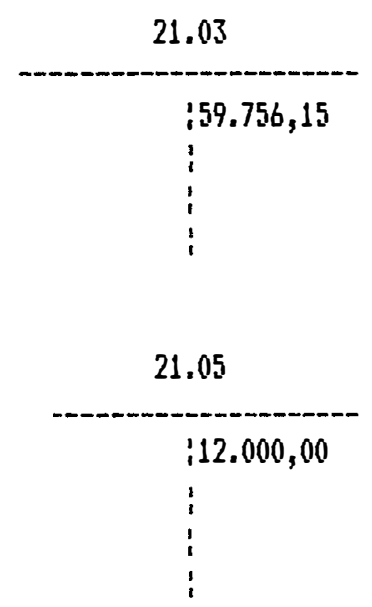

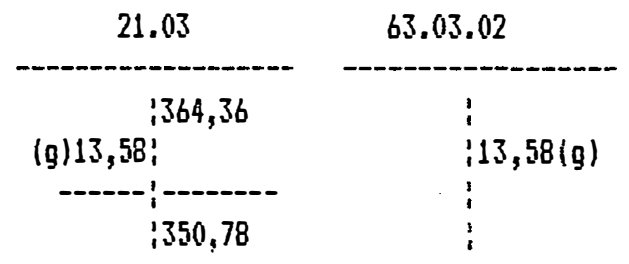

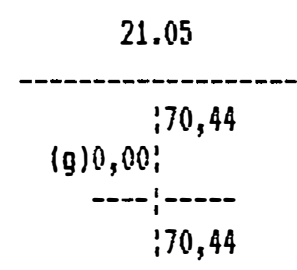

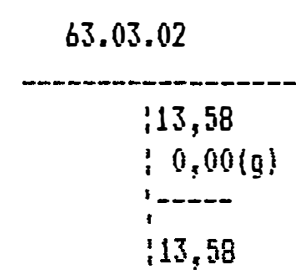

Fóroula (18): gro $(t)=$ otrf $(t)-[\operatorname{otfn}(t) /$ def $(t)]$

$$
\begin{aligned}
& \text { gro }(t)=364,36-[59.756,15 / 170,35] \\
& \text { gro }(t)=364,36-350,78 \\
& \text { gro }(t)=13,58
\end{aligned}
$$

$$
\begin{aligned}
& \text { gro }(t)=70,44-[12.000,00 / 170,35] \\
& \text { gro }(t)=70,44-70,44 \\
& \text { gro }(t)=0
\end{aligned}
$$


Figura B. Encerramento de Contas e Distribuiçăo dos Resultados

CONTABILIZACAO EH US\$

VALOR BRUTO DA PRODUÇAO DO PERIODO

- Milho-6rzo

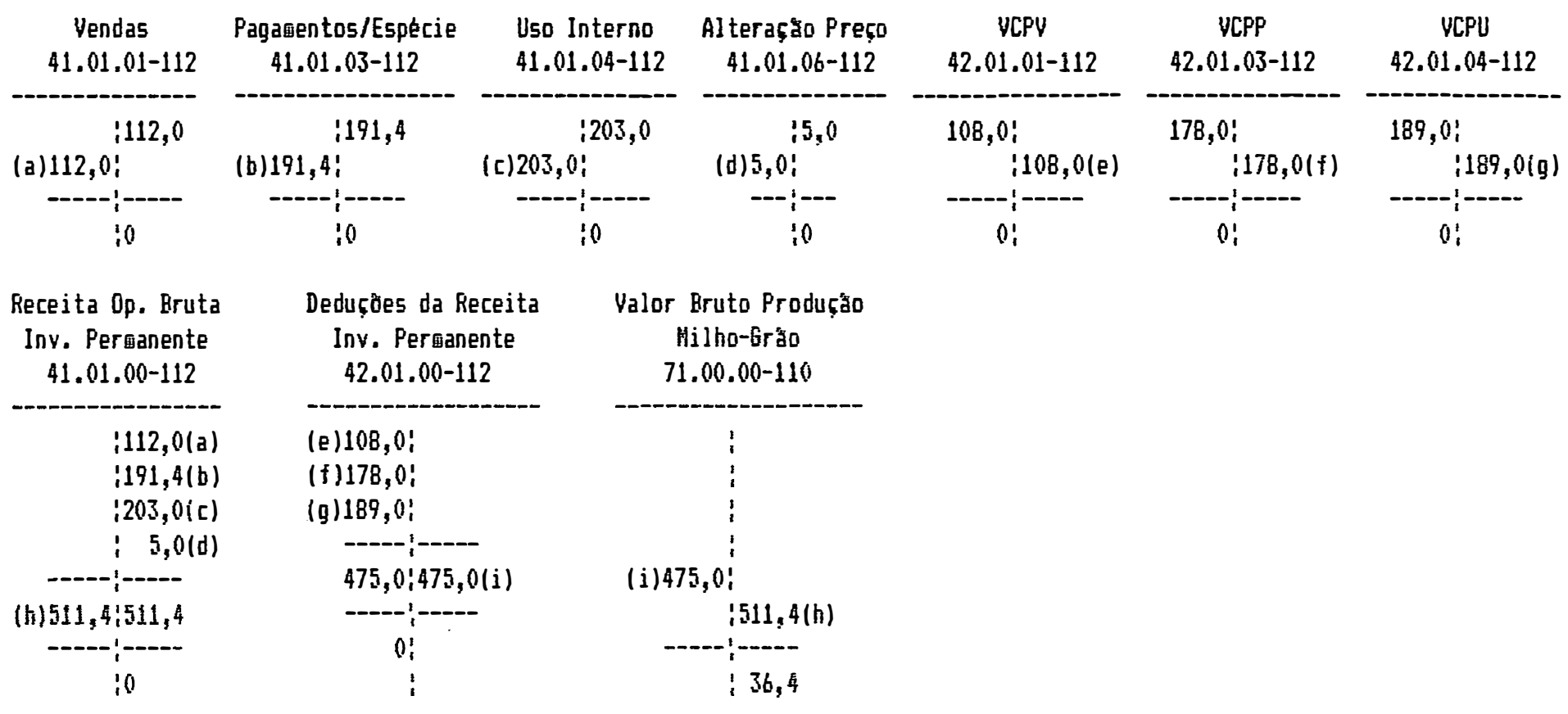

- Pastager Andropogur

\begin{tabular}{|c|c|c|c|}
\hline $\begin{array}{l}\text { Uso Interno } \\
41.02 .04-211\end{array}$ & $\begin{array}{l}\text { Receita Op.Bruta } \\
\text { Inv. Perioddico } \\
41.02 .00-210\end{array}$ & $\begin{array}{l}\text { Deduçóes da Receita } \\
\text { Inv. Feriódico } \\
42.02 .00-210\end{array}$ & $\begin{array}{c}\text { Valor Bruto Froducáa } \\
\text { Pastagea } \\
71.00 .00-210\end{array}$ \\
\hline - & - & -- & - \\
\hline$: 907,4$ & i & 1 & $:$ \\
\hline (a) $907,4 i$ & $\lceil 907,4(a)$ & $:$ & $\vdots$ \\
\hline -----!----- & (b) 907,4 ! & $!$ & $: 907,4(b)$ \\
\hline 10 & ---- & $---1---$ & $:$ \\
\hline : & 10 & $0 !$ & 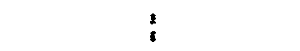 \\
\hline
\end{tabular}

- Pecuária de Leite (Anigais)

\begin{tabular}{|c|c|c|c|}
\hline Vendas & Variaça do Estoque & Compras & Recebigentos/Espécie \\
\hline $41.02 .01-310$ & $41.06 .02-310$ & $42.02 .01-310$ & $42.02 .02-310$ \\
\hline (a) $3.253,9 ?^{: 3.253,9}$ & $\begin{array}{l}248,5 ! \\
\qquad 248,5(b)\end{array}$ & $\begin{array}{l}3.800,0 ! \\
: 3.800,0(c)\end{array}$ & $\begin{array}{l}69,3 ! \\
\quad ; 69,3(d)\end{array}$ \\
\hline ------!----- & $----\cdots$ & -C- & $-\cdots ;-\cdots$ \\
\hline 10 & 10 & $0 !$ & $0 !$ \\
\hline
\end{tabular}

(continua) 


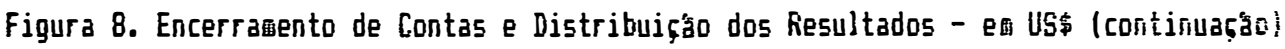

\begin{tabular}{|c|c|c|}
\hline $\begin{array}{l}\text { Receita Op.Bruta } \\
\text { Inv. Feribdico } \\
41.02 .00-310\end{array}$ & $\begin{array}{c}\text { Deduçoes da Feceita } \\
\text { Inv. Feribdico } \\
42.02 .00-310\end{array}$ & $\begin{array}{c}\text { Valor Bruto Froduçác } \\
\text { (Animais) } \\
71.00 .00-310\end{array}$ \\
\hline $3.253,9(a)$ & (c) $3.800,0$ ? & i \\
\hline (b) $248,5 i$ & (d) $69,3 i$ & $\vdots$ \\
\hline - & 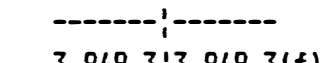 & 1312060 \\
\hline (е) $3.005,4: 3.005,4$ & $3.869,3 ; 3.869,3(f)$ & (f) $3.869,3: 3.005,4(\mathrm{e})$ \\
\hline 10 & $0 i$ & $863,9 i$ \\
\hline
\end{tabular}

- Pecuária de Leite (Leite)

\begin{tabular}{|c|c|c|c|}
\hline $\begin{array}{c}\text { Vendas } \\
41.03 .01-310\end{array}$ & $\begin{array}{c}\text { Consumo Interno } \\
41.03 .02-310\end{array}$ & $\begin{array}{c}\text { Receita Op. Bruta } \\
\text { Apropriaça Direta } \\
41.03 .00-310\end{array}$ & $\begin{array}{c}\text { Valor Bruto Froduçá } \\
\text { (Leite) } \\
71.00 .00-310\end{array}$ \\
\hline (g) $1.008,7 i^{i .008,7}$ & (h) $22,0 !$ & $\begin{array}{l}\vdots \\
11.008,7(g) \\
\vdots \quad 22,0(h)\end{array}$ & $\vdots$ \\
\hline $\begin{array}{l}0 \\
\vdots \\
i \\
i\end{array}$ & $\begin{array}{l}\vdots 0 \\
\vdots \\
\vdots\end{array}$ & \begin{tabular}{c:c}
0 & $030,1.030,7$ \\
\hdashline & 0
\end{tabular} & $i 1.030,7(i)$ \\
\hline
\end{tabular}

- Pecuária de Leite (Total)

\begin{tabular}{|c|c|c|}
\hline $\begin{array}{c}\text { Valor Bruto Froduçáo } \\
\text { (Animais) } \\
71.00 .00-310\end{array}$ & $\begin{array}{c}\text { Valor Bruto Froducáa } \\
\text { (Leite) } \\
71.00 .00-310\end{array}$ & $\begin{array}{l}\text { Valor Bruto Froduçáno } \\
\text { Fecudria de Leite } \\
71.00 .00-310\end{array}$ \\
\hline $\begin{array}{r}863,9 ! \\
: 863,9(a)\end{array}$ & (b) $1.030,7 i^{i 1.030,7}$ & (a) $863,9: 1.030,7(b)$ \\
\hline$: 0$ & 0 & 166,8 \\
\hline
\end{tabular}

- Outras Atiyidades

\begin{tabular}{|c|c|c|c|}
\hline $\begin{array}{l}\text { Vendas } \\
41.03 .01-400\end{array}$ & $\begin{array}{c}\text { Consumo Interno } \\
41.02 .02-400\end{array}$ & $\begin{array}{c}\text { Pagagentos/Espécie } \\
41.02 .03-400\end{array}$ & $\begin{array}{c}\text { Variaçăo do Estoque } \\
41.02 .05-400\end{array}$ \\
\hline$: 1,0$ & (4) 27,0 & 20,0 & $: 12,6$ \\
\hline $\begin{aligned}(a) 1,0 ! \\
-\cdots !--\end{aligned}$ & $\begin{array}{l}\text { (b) } 27,0 ! \\
----\cdots\end{array}$ & $\begin{array}{l}\text { (c) } 20,0 ! \\
-\cdots\end{array}$ & \begin{tabular}{l} 
(d) $12,6 !$ \\
\hdashline$-\cdots$
\end{tabular} \\
\hline 10 & :0 & $: 0$ & 10 \\
\hline
\end{tabular}


Figura 8. Encerramento de Contas e Distribuiçáo dos Resultados - eq US\$ (continuaçăs)

\begin{tabular}{|c|c|c|c|}
\hline $\begin{array}{l}\text { Receita Op.Bruta } \\
\text { Inv. Peribdico } \\
41.02 .00-400\end{array}$ & $\begin{array}{c}\text { Deduç8es da Receita } \\
\text { Iny. Peribdico } \\
\text { 42.02.00-400 }\end{array}$ & $\begin{array}{c}\text { Receita Op.Bruta } \\
\text { Apropria } \$ \text { \$o Direta } \\
41.03 .00-400\end{array}$ & $\begin{array}{c}\text { Valor Bruto Produçato } \\
\text { Dutras Atividades } \\
71.00 .00-400\end{array}$ \\
\hline - & - & & \\
\hline$: 27,0(b)$ & $i$ & : & 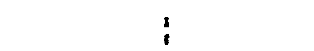 \\
\hline $120,0(c)$ & $i$ & $(f) 1,0 ; 1,0(a)$ & $: 1,0(e)$ \\
\hline $1,12,6(d)$ & $---! \cdot---$ & $---!--$ & $: 59,6(f)$ \\
\hline$---\infty:--$ & $0 !$ & $: 0$ & $---;-\cdots$ \\
\hline (e) $59,6: 59,6$ & ; & : & $: 60,6$ \\
\hline$---1-\cdots$ & ! & $i$ & $i$ \\
\hline$: 0$ & $!$ & $:$ & $i$ \\
\hline
\end{tabular}

- Centro de Resultados Indiretos

Receita Dp. Bruta Valor Bruto Produçào

Prestaçóses Serviços Centro Resultados Indiretos

41.04.00-999

$71.00 .00-999$

(a) $100,0:$\begin{tabular}{c}
100,0 \\
\hdashline \\
\hdashline 0
\end{tabular}

$\vdots$
$\vdots$
$\vdots$

\section{- Eqpresa}

Valor Bruto Produçáo Valor Bruto Produçăo Eilho-Gráo

$71.00 .00-110$ Pastaget $71.00 .00-210$

Valor Bruto Produçăo Pecúdria de Leite

Valor Bruto Produçáo Dutras Atividades

Valor Bruto Prociuça Valor Bruto Produçác

\begin{tabular}{c}
136,4 \\
$(a) 36,4 !$ \\
\hdashline 0
\end{tabular}

:907,4

\begin{tabular}{c}
$71.00 .00-310$ \\
\hdashline 166,8 \\
\hdashline$: 0$
\end{tabular}

\begin{tabular}{c}
$71.00 .00-400$ \\
(d) $60,60,6$ \\
\hdashline$: 0$
\end{tabular}
Centro Res. Indiretos Eqpresa

$71.00 .001-995$

(e) $100,0 !$

71

\begin{tabular}{c}
$36,4(a)$ \\
$907,4(b)$ \\
$16 b, 8(c)$ \\
$60,6(d)$ \\
$100,0(e)$ \\
\hdashline $1.271,2$
\end{tabular}

HARGEH SOBRE CUSTOS VARIAUEIS

\section{- Milho-Grto}

\section{Ma-de-Obra Tetporária $51.01 .00-110$}

$$
34,9 !
$$$$
134,9(a)
$$$$
---:---
$$$$
0 !
$$

(0!

$$
\begin{gathered}
\text { Custos Variáveis } \\
\text { Hilho-6rầo } \\
51.00 .00-110
\end{gathered}
$$

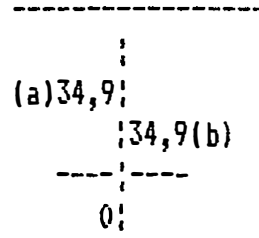

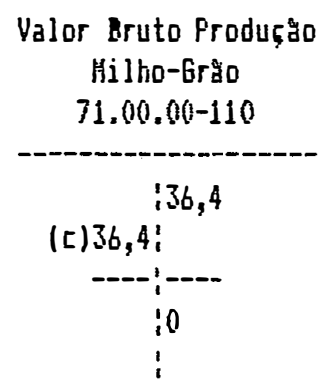


Figura 8. Encerramento de Contas e Distribuiçăo dos Kiesultados - eq US\$ (continuaçăo)

\section{- Pastagea Andropogus}

\begin{tabular}{|c|c|c|c|}
\hline $\begin{array}{c}\text { Serviços Terceiros } \\
51.02 .01-210\end{array}$ & $\begin{array}{c}\text { Custos Variáveis } \\
\text { Pastagem } \\
51.00 .00-210\end{array}$ & $\begin{array}{c}\text { Valor Bruto Produçato } \\
\text { Pastage日 } \\
71.00 .00-210\end{array}$ & $\begin{array}{c}\text { Marget Cus tos Variáveis } \\
\text { Pastage- } \\
72.01 .00-110\end{array}$ \\
\hline \begin{tabular}{l}
$20,0 !$ \\
$: 20,0(a)$ \\
\hdashline$:-$
\end{tabular} & $\begin{array}{c}\vdots \\
(\mathrm{a}) 20,0 \vdots \\
: 20,0(b)\end{array}$ & (c) $907,4 !^{i 907,4}$ & (b) $20,0 ?^{907,4(c)}$ \\
\hline $0 !$ & $0^{-\cdots}$ & $\vdots$ & $\begin{array}{r}----- \\
: 887,4\end{array}$ \\
\hline
\end{tabular}

- Pecuária de Leite

\begin{tabular}{cc} 
Alimentos Concentrados \\
$51.07 .00-310$ & Alimentos Volumosos \\
$51.08 .00-310$ \\
\hdashline 174,0 \\
\hdashline $174,0(a)$ & $33,0 !$ \\
\hdashline 0 & $\vdots 33,0(b)$ \\
\hdashline & 0 \\
\hdashline & $\vdots$
\end{tabular}

\begin{tabular}{l} 
Custos Variáveis \\
Pecuária de Leite \\
$51.00,00-310$ \\
\hdashline \begin{tabular}{c} 
(a) $174,0 !$ \\
(b) $33,0 !$ \\
\hdashline $207,0 ! 207,0(c)$ \\
\hdashline$-\cdots$
\end{tabular}
\end{tabular}

Valor Eruto Produça Pecuária de Leite

$71.00 .00-310$

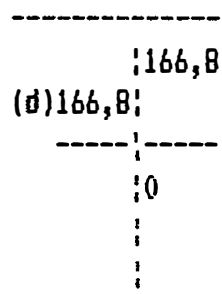

- Outras Atividades

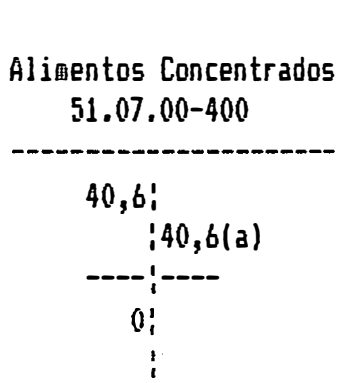

Custos Variáveis

Valor Bruto Froduçăo

Harget Custos Väriáveis

Outras Atividades Outras Atividades

$51.00 .00-400$

$71.00 .00-400$

Outras Atividades

72.01.00-400
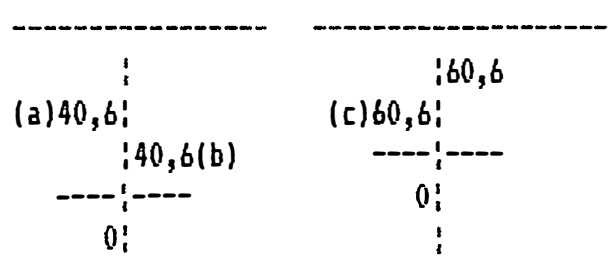

- Centro de Resultados Indiretos

\begin{tabular}{c} 
Compras-Combustíveis \\
$51.03 .21-999$ \\
\hline
\end{tabular}

Variaçăa do Estoque Combustíveis 51.03.15-999

$26,0 !$ $: 26,0(a)$

$-\cdots:---$

0 i

113,0

(b) 13,0 ! $----\cdot---$ $: 0$

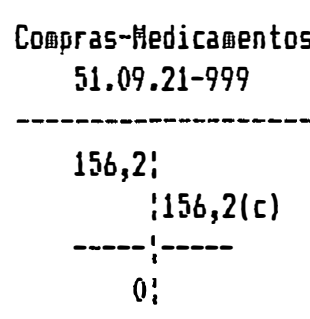
Variaçáa do Estoque Hedicamentos 51.09.15-799
$: 93,7$

(d) 93,7 :<smiles>C[In](C)C</smiles>

Harget Custos Variáveis Pecuária de Leite 72.01.00-310

\begin{tabular}{c}
$\vdots 166,8(d)$ \\
(c) $207,0 !$ \\
\hdashline $40,2 !$ \\
\hdashline
\end{tabular}

(continua) 
Figura 8. Encerratento de Contas e Distribuiçăo dos Resultados - e⿴囗十 USt (continuaça)

Velc. Maq.Equip.loplet. Medicatentos e Vacinas Centro Result.Indiretos Centro Result.Indiretos $51.03 .00-999$

$$
\begin{aligned}
& \text { (a) 26,0: } \\
& : 13,0(b) \\
& ----:--- \\
& 13,0 ; 13,0(\mathrm{e}) \\
& \text { - }
\end{aligned}
$$

$$
\text { (c) } 156,2 ;
$$

$$
\begin{gathered}
: 93,7(d) \\
\hdashline 62,5 ! 62,5(f) \\
\hdashline 0 !-- \\
0 !
\end{gathered}
$$

Custos Variáveis

Centro Result. Indiretos

$$
51.00 .00-999
$$

(e) 13,0 :

(f) 62,5 !

$----!---$

75,$5 ; 75,5(g)$

$0 !$
Valor Bruto Produçáco Centro Resultados Indiretos $71.00 .00-999$

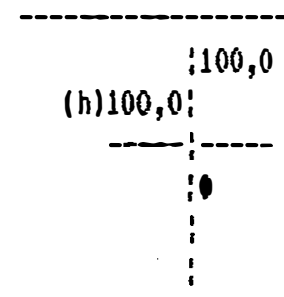

Harget Custos Variáveis Centro Result. Indiretos 72.01.00-999

$\{100,0(\mathrm{~h})$

\section{- Espresa}

Marget Custos Variáveis Hilho-6räo

72.01.00-110

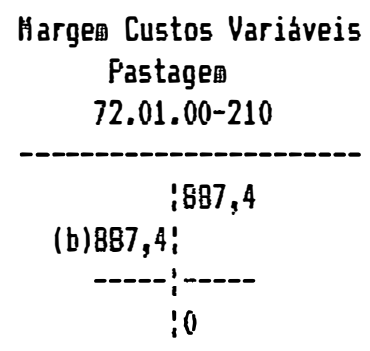
harget Custos Variáveis Pecuária de Leite 72.01.00-310

\begin{tabular}{c}
$72.01 .00-310$ \\
\hdashline $40,2 !$ \\
\hdashline$: 40,2(c)$ \\
\hdashline$-\cdots$
\end{tabular}

Harget Custos Variáveis
Butras Atividades

Harget Custos Variáveis

Centro Result. Indiretos

$i 1,5$
(a) $1,5 !$
$\cdots$
$\vdots 0$

Marget Custos Variàveis Etpresa

72

$1,5(a)$
$i 887,4(b)$

(c) 40,2:

$$
\$ 887,4(b)
$$

\begin{tabular}{l:l}
$20,0(d)$ \\
$24,5(e)$ \\
\hdashline$:-$ \\
\hdashline 993,2
\end{tabular}

LUCRO (PREJUIZO) BRUTO DA PRODUÇAD

- Milho-Gra

Alugueis e Arrendamentos

Hilho-6räo

52.04.00-110

Depreciaçies Equipam.e I ippletentos $52.05 .00-110$

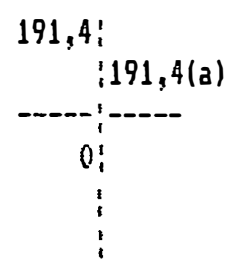

1,$2 ;$

$11,2(b)$

$---;--$

$0:$

i
72.01.00-400

72.01.010-999

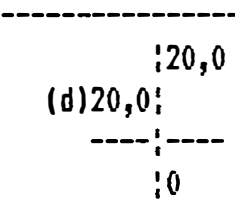


Figura 8. Encerramento de Contas e Distribuiçăo dos Resultados - ê US\$ (continuą̧as)

\begin{tabular}{|c|c|c|}
\hline $\begin{array}{c}\text { Custos Bens Produzidos } \\
\text { Hilho-6răo } \\
54.00 .00-110\end{array}$ & $\begin{array}{c}\text { Valor Bruto Produça } \\
\text { Hilho-6rào } \\
71.00 .00-110\end{array}$ & $\begin{array}{c}\text { Lucro Bruto Produsago } \\
\text { Hilho-6rato } \\
73.01 .00-110\end{array}$ \\
\hline (c) 192,6 ; & 36,4 & $\dot{3}$ \\
\hline (d) 34,9 ? & $(9) 36,4 i$ & $136,4(9)$ \\
\hline -----!:---- & $-\cdots:---$ & $i$ \\
\hline 227,$5 ; 227,5(\mathrm{e})$ & 10 & $i$ \\
\hline$-\cdots:-\cdots$ & $:$ & $i$ \\
\hline$(f) 0_{i}^{i}$ & i & i \\
\hline
\end{tabular}

\section{- Pastager Andropogug}

\begin{tabular}{|c|c|c|c|c|c|}
\hline $\begin{array}{l}\text { Depreciaçbes } \\
\text { Culturas Perenes } \\
52.05 .00-210\end{array}$ & $\begin{array}{l}\text { Custos Fixos } \\
\text { Pastage画 } \\
52.00 .00-210\end{array}$ & $\begin{array}{c}\text { Custos Variáveis } \\
\text { Pastagem } \\
51.00 .00-210\end{array}$ & $\begin{array}{c}\text { Custos Hens Produzidos } \\
\text { Pastagem } \\
54.00 .00-210\end{array}$ & $\begin{array}{c}\text { Valor Bruto Produça } \\
\text { Pastagem } \\
71.00 .00-210\end{array}$ & $\begin{array}{c}\text { Lucro Bruto Produçà } \\
\text { Pastage相 } \\
73.01 .00-210\end{array}$ \\
\hline $\begin{array}{c}736,2: \\
: 736,2(a)\end{array}$ & 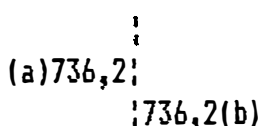 & $\begin{array}{l}20,0: \\
: 20,0(c)\end{array}$ & $\begin{array}{l}\text { (b) } 736,2: \\
\text { (c) } 20,0 ! \\
\end{array}$ & (e) $9007,4 i^{i 907,4}$ & $907,4(e)$ \\
\hline $0 !$ & ----!:---- & $0 !$ & $756,2: 756,2(d)$ & io & (d) $756,2 i$ \\
\hline$i$ & $0 !$ & $!$ & ----:--- & $i$ & ----'----- \\
\hline$:$ & : & $i$ & $0 !$ & : & $: 151,2$ \\
\hline
\end{tabular}

\section{- Pecuária de Leite}

\begin{tabular}{|c|c|c|c|c|}
\hline $\begin{array}{c}\text { Variaçăo do Estoque } \\
\text { Arame Ovalado } \\
51.10 .15-310\end{array}$ & $\begin{array}{l}\text { Hateriais de Consu酸 } \\
51.10 .00-310\end{array}$ & $\begin{array}{l}\text { Constr.lnstal. helhor. Alug } \\
\text { Pecuaria de Leite Pec } \\
52.02 .00-310\end{array}$ & $\begin{array}{l}\text { is e Arrendament. } \\
\text { ria de Leite } \\
04.00-310\end{array}$ & $\begin{array}{r}\text { Depre } \\
\text { Equip. e } \\
52.05 .\end{array}$ \\
\hline \begin{tabular}{c}
38,6 \\
$\vdots 38,6(a)$ \\
\hdashline$\vdots 0$ \\
$\vdots$ \\
$\vdots$
\end{tabular} & \begin{tabular}{c}
$(a) 38, b !$ \\
$\vdots 38,6(b)$ \\
\hdashline$-\cdots$ \\
$\vdots$ \\
$\vdots$
\end{tabular} & 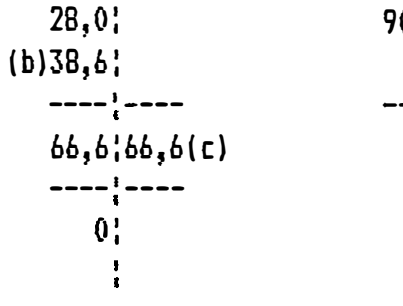 & \begin{tabular}{c}
$4 !$ \\
$: 907,4(d)$ \\
\hdashline $0 !$ \\
\hdashline \\
$\vdots$ \\
$\vdots$
\end{tabular} & . \\
\hline $\begin{array}{l}\text { Custos Variáveis } \\
\text { Pecuária Leite } \\
51.00 .00-310\end{array}$ & $\begin{array}{c}\text { Custos Bens Produzidos } \\
\text { Pecuária de Leite } \\
54.00 .00-310\end{array}$ & $\begin{array}{c}\text { Valor Bruto Produçăo } \\
\text { Pecuária de Leite } \\
71.00 .00-310\end{array}$ & $\begin{array}{r}\text { Prejujzo Bristo } \\
\text { Pecuaria se } \\
73.01 .00-\end{array}$ & $\begin{array}{l}\text { Produçáa } \\
\text { Leite } \\
-310\end{array}$ \\
\hline $\begin{array}{c}207,0: \\
: 207,0(g)\end{array}$ & $\begin{array}{r}(f) 1.091,8: \\
(g) 207,0 ! \\
\hdashline\end{array}$ & (i) $166,8:$ & $\begin{array}{r}(h) 1.298,8: \\
\hdashline: 56, \\
\hdashline \hdashline\end{array}$ & Bii) \\
\hline $\begin{array}{r}0 \\
\vdots \\
\vdots \\
1\end{array}$ & \begin{tabular}{c}
$1.298,8: 1.298,8(\mathrm{~h})$ \\
\hdashline $0 !$
\end{tabular} & $\begin{array}{r}0 ! \\
\vdots \\
\vdots\end{array}$ & $\begin{array}{r}1.132,0 ! \\
\vdots \\
\vdots\end{array}$ & \\
\hline
\end{tabular}




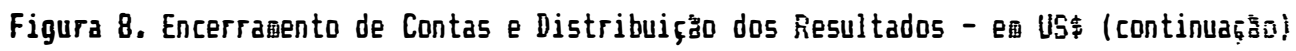

\section{- Outras Atividades}

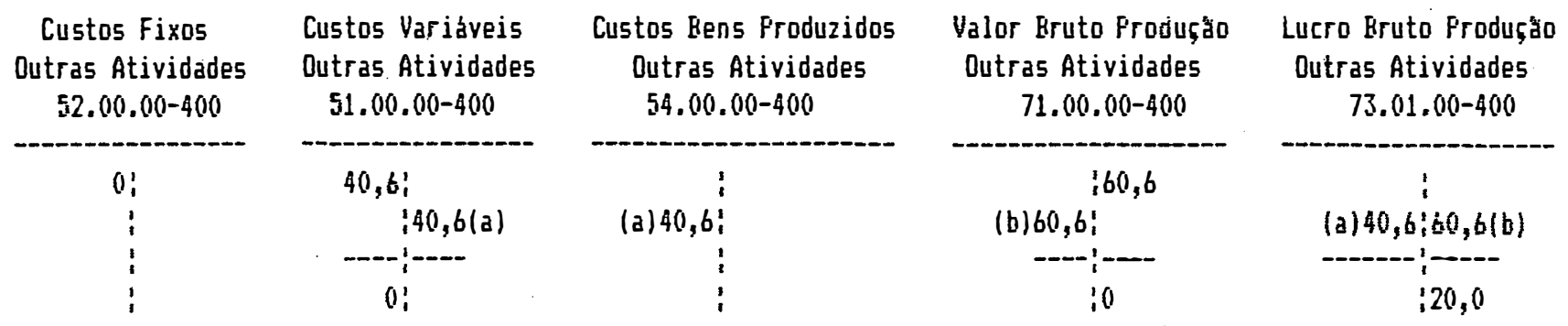

- Centro de Resultados Indiretos

Ha-de-Obra Fermanente

Centro Kesult. Indiretos

52.01.010-999

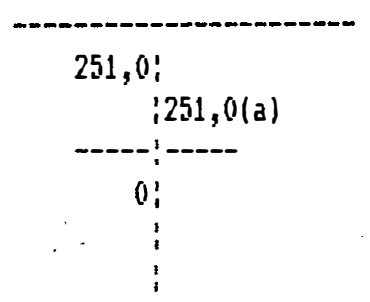

Custos Bens Froduzidos

Centro Result. Indiretos $54.00 .00-999$

(c) 467,3 i

(d) 75,5 :

$-\cdots$

542,$8 ; 542,8(\mathrm{e})$

$----\cdot-----$

0 !
Depreciaçすes

Centro Result. Indiretos 52.05.001-999

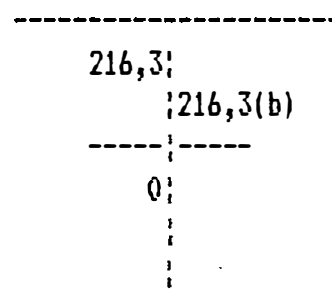

Valor Bruto Froduçăa

Centro Kes.Indiretos

$71.00 .001-999$

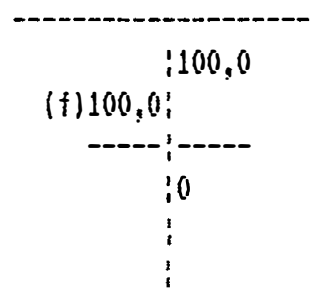

Custos Fixos

Centro Result.Indiretos

$52.00 .00-999$

(a) 251,0 :

(b) 216,3 ;

$-----:----$

$467,3: 467,3(c)$

0 :----

Frejuizo Bruto Froduça

Centro Result. Indiretos

73.01.00-999

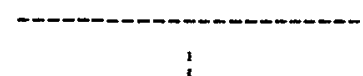

(e) $542,8: 100,01 f)$

-------:----

$442,8:$
Custos Variáveis

Centro Result. Indiretos

$51.00 .00-999$

$75,5 !$

$: 75,5(d)$

$---\cdots$

$0:$

i

- Eqpresa

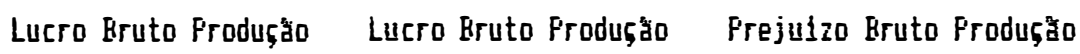

Hil ho-Grăo

$73.01 .001-110$

\begin{tabular}{c}
136,4 \\
\hdashline $36,4 !$ \\
\hdashline$\vdots 0$
\end{tabular}

Fastage画

$73.01 .001-210$

$: 151,2$

(b) 15i, 2i

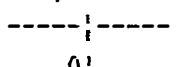

0 :
Fecuária de Leite

73.01.001-310

$1.132,0 !$

\begin{tabular}{c}
$11.132,0(c)$ \\
\hdashline 0
\end{tabular}
Luero Bruto Frodusăo Outras Atividades

73. $01.00-400$

\begin{tabular}{c}
120,0 \\
\hdashline 0
\end{tabular}

Frejuízo Bruto Froduçąo Centro Custos Indiretos 73.01.00-999

\begin{tabular}{c}
$442,8:$ \\
\hdashline $442,8(e)$ \\
\hdashline $0 !$
\end{tabular}

(continua) 
Figura 8. Encerragento de Contas e Distribuifás dos Resultados - eq USs (continuaçso)

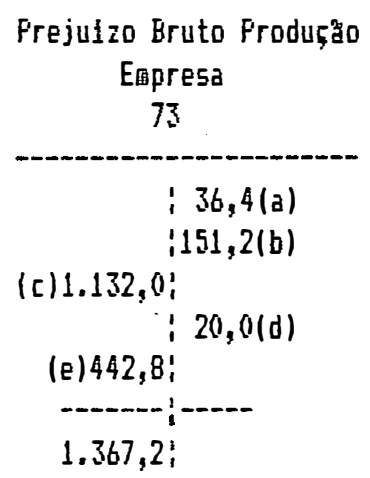

LUCRO (PREJUIZO) DFERACIONAL

- Eqpresa

\begin{tabular}{|c|c|c|c|c|}
\hline $\begin{array}{c}\text { Despesas Adqinistratiyas } \\
61.02\end{array}$ & $\begin{array}{c}\text { Despesas Financeiras } \\
61.03\end{array}$ & $\begin{array}{c}\text { Despesas Dperacionais } \\
61\end{array}$ & $\begin{array}{c}\text { Frejuizo Bruto Froduço } \\
\text { Elopresa } \\
73\end{array}$ & $\begin{array}{c}\text { Frejulzo Operacional } \\
\text { Etopresa } \\
74\end{array}$ \\
\hline $\begin{array}{l}183,8: \\
\quad: 183,8(a)\end{array}$ & (b) $136,3 !^{136,3}$ & $\begin{array}{l}(a) 183,8: \\
: 136,3(b)\end{array}$ & $\begin{array}{l}1.367,2 ! \\
i 1.367,2(d)\end{array}$ & $\begin{array}{r}\text { (c) } 47,5 ; \\
\text { (d) } 1.367,2 ;\end{array}$ \\
\hline -----!----- & ---- & $----:---$ & - - - & $\cdots+\cdots$ \\
\hline $0 !$ & 10 & $47,5 ! 47,5(c)$ & $0 !$ & $1.414,7 !$ \\
\hline$:$ & 1 & $-\cdots--\cdots$ & 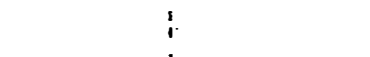 & $i$ \\
\hline$i$ & $\vdots$ & $0:$ & $!$ & $\vdots$ \\
\hline
\end{tabular}

LUCRO (PREJUIZO) ANTES DO IHFOSTO DE RENDA

\section{- Eqpresa}

Ganhos Vendas Bens Capita] 43.01

\begin{tabular}{c}
1171,1 \\
(a)171,1! \\
\hdashline$: 0$ \\
$\vdots$
\end{tabular}

Receitas Nao-Operacionais 43

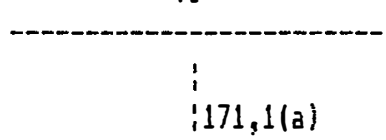

(b) 171,1;

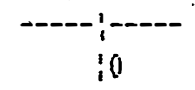

Retiradas Especie 62.03

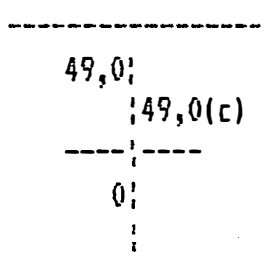

Despesas Näo-Dperacioriais

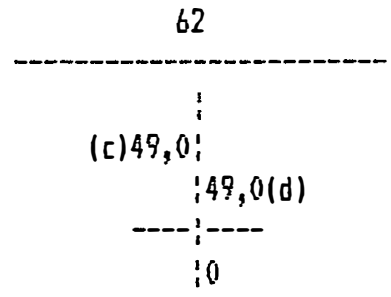

Frejufzo Operacional

Empresa

74

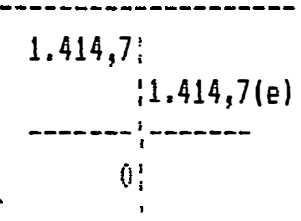

Frejuizo Antes I.R. Expresa 75

(e)1.414,7!

(d) 49,0 !

-

$1.272,6 !$ 


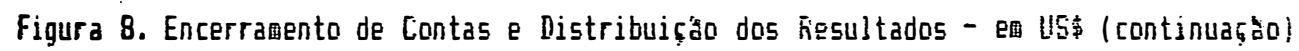

LUCRO (PREJUSZO) DEPOIS DO IMPOSTO DE RENDA

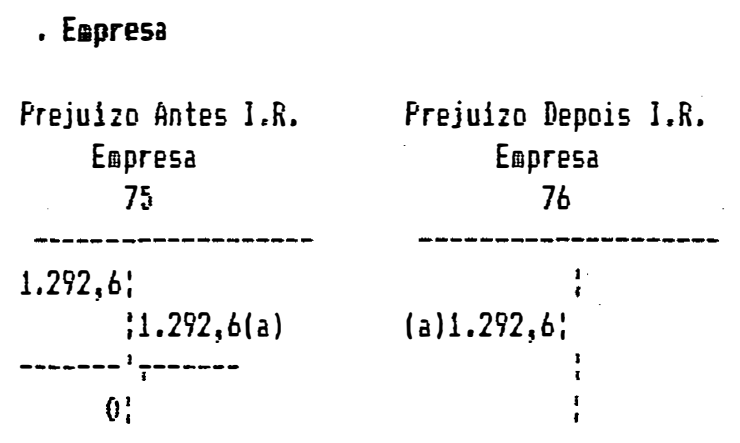

PERDAS (GAHHOS) HDS ITEHS HOHETARIOS

- Eqpresa

Perdas Itens Monetarios Eanhos Itens Honetários 63. 13.01

\begin{tabular}{c}
$266,4 !$ \\
$\vdots 266,4(a)$ \\
\hdashline$!$
\end{tabular}

63.03 .012
Perdas Itens Honetários Dutras Despesas Eqpresa 63.03
Expresa
63

(a) 266,4 ;

(b) $13,6:$

\section{3,6}

--1;

10 (c) 252,8;

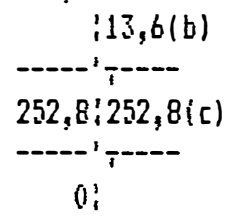

LUCRO (PREJUIZO) LIQUIDO

- Empresa

Preju1zo Depois 1.R. Empresa

76

$1.292,6$ !

${ }^{i 1.292,6(a)}$
Jutras Despesas

Eqpresa

63

$252,8 !$
$i 25,8,8(b)$
$0 !$

Prejuizo Liquido

Etpresa

76

(a) 11.292,6:

(b) 252,8 ;

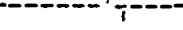

$1.545,4:$

DISTRIBUICGAO DOS RESULTADOS
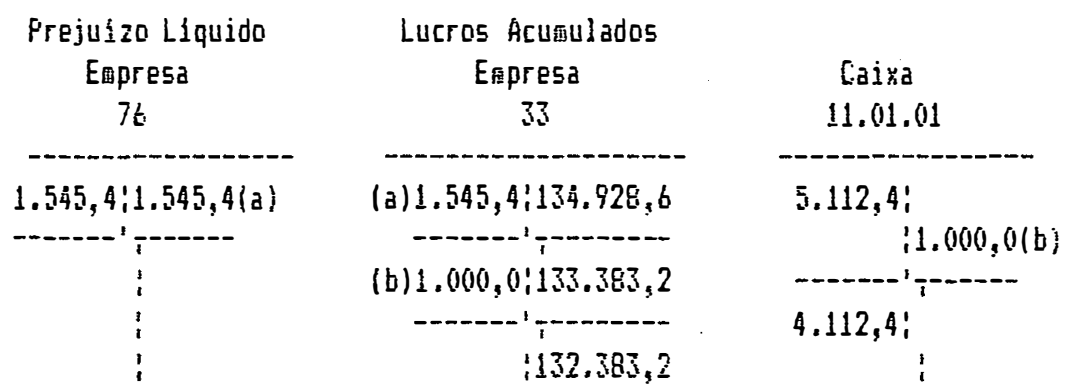

(continua) 


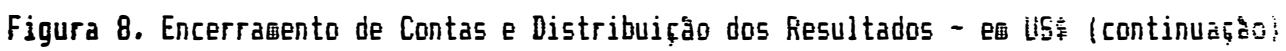

ALOCAÇBES DOS CUSTOS INDIRETOS

MARGEH SOBRE CUSTOS VARIAVEIS APOS ALOCAÇOES

\section{. Milho-6răo}

hargem Custos Variáveis

kiilho-6rabo

72.01.001-110

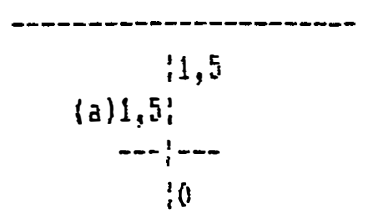

- Pastagem Andropoguis

Hargem Custos Variáveis Pastagem

72.01.001-210

\begin{tabular}{c}
$: 887,4$ \\
(a) $887,4 !$ \\
\hdashline$: 0$
\end{tabular}

- Pecuária de Leite

hargem Custos Variáveis Pecuária de Leite $72.01 .00-310$

\begin{tabular}{c}
$40,2 i$ \\
$i 40,2(a)$ \\
\hdashline$\vdots$
\end{tabular}

\section{- Outras}

Margew Custos Variáveis Dutras Atividades 72.01.00-400

\begin{tabular}{c} 
(a) $20,0 !$ \\
\hdashline$\vdots 0,0$ \\
\hdashline$\vdots$
\end{tabular}

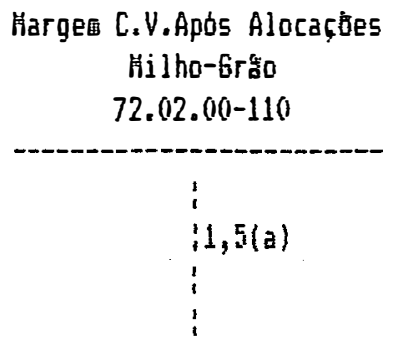

hargem C.V.Apos Alocaçồes Pastagei 72.02.010-210

$\vdots$
$\vdots$
$\vdots$

Vetc. Haq. Equip. I ipplem. Centro fiesult. Indiretos $51.03 .00-999$

\begin{tabular}{c}
$13,0 !$ \\
$: 10,4(b)$ \\
\hdashline $2, b !$
\end{tabular}

Veic.haq.Equip. Impleq. Centro fiesult. Indiretos $51.03 .001-999$

\begin{tabular}{c}
$2,6 !$ \\
$i 2,6(b)$ \\
\hdashline$\vdots$ \\
$\vdots$
\end{tabular}

Hedicamentos e Vacinas Centro fiesult. Indiretos $51.09 .00-999$

\begin{tabular}{c}
$62,5 !$ \\
$50,01(c)$ \\
\hdashline $12,5 !$
\end{tabular}

Hedicamentos e Vacinas Centro fiesult. Indiretos $51.09 .00-999$

\section{2,5}

$: 12,5(c)$

$-\cdots:-\cdots$

$0 !$

;

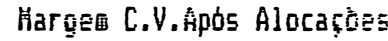
Pecuária de Leite $72.02 .010-310$

(a) 40,2 :

(b) $10,4:$

(c) 50,0 :

-

100,6 :
Hargew C.V.Após Alocą̧ces Jutras Atividades 72.02.010-400

\begin{tabular}{c}
$120,0(a)$ \\
(b) $2,6 !$ \\
(c) $12,5:$ \\
\hdashline$: 9$,
\end{tabular}




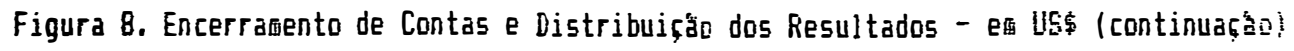

LUCRO (PREJUIIO) BRUTO AFOS ALOCAÇBES

- Milho-6ro

\begin{tabular}{|c|c|c|}
\hline $\begin{array}{c}\text { Lucro Bruto Producäo } \\
\text { hilho-6räo } \\
73.01 .00-110\end{array}$ & $\begin{array}{c}\text { Custos Fixos } \\
\text { Centro Result. Indiretos } \\
52.00 .00-999\end{array}$ & $\begin{array}{c}\text { Lucro B.P.Apos Alocaçoes } \\
\text { Hilho-6ráo } \\
73.02 .00-110\end{array}$ \\
\hline 136,4 & $467,3 !$ & $i$ \\
\hline$(a) 36,4 i$ & $: 145,7(b)$ & (b) $145,7 ! 36,4(5)$ \\
\hline$-\infty ;---$ & $-\cdots,-\cdots$ & -----:--- \\
\hline $0 !$ & $321,6 !$ & $109,3:$ \\
\hline
\end{tabular}

\section{- Pastagef Andropogur}

Lucro Bruto Producáa

Pastage西

73. $01.001-210$

(a) $151,2 \vdots: 151,2$

- Pecuária de Leite

Prejufzo Bruto Produçăo

Pecuária de Leite

$73.01 .0010-310$

$1.132,0 ;$

$11.132,0(a)$

oi

\section{- Outras Rtividades}

Lucro Bruto Producáa Dutras Atividades

$73.01 .001-400$

$: 20,0$

(a) 20,0 :

10.
$\vdots$
$\vdots$
Custos Variáyeis Centro Result. Indiretos $51.00 .00-999$

15,$1 ;$

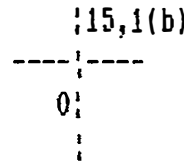

Custos Firos

Centro Result. Indiretos

52.00 .0010999

219,9 ;

\begin{tabular}{c}
$1115,8(c)$ \\
\hdashline $104,1 !$
\end{tabular}
Prejuizo B.P.Aftis Alocefótes Pecub́ria de Leite $73.02 .001-310$

(a) $1.132,0$;

(b) 60,4:

(c) 115,8 ;

$1.305,2 !$
Custos Firos

Centro Result. Indiretos

$52.00 .001-999$

104,1;

$: 104,1(c)$

$----i-\cdots$

(1)
Lucro F.P.Após Alocaçóes Dutras Atividades $73.02 .001-400$

$120,0(a)$

(b) 15,1;

(c) 104,1: - 
10. Elaboração e Breve Análise dos Relatórios Contábeis

A Tabela 32 corresponde ao Balanco Patrimonial da Fazenda Bocaina, no final do periodo contábil, ou seja, em 01/JANEIRO/1991. Já as Tabelas 33 e 34 referem-se, respectivamente, à Demonstração do Resultado do Exercício da Empresa e de suas Atividades Produtivas e ao Demonstrativo de Fluxo de Caixa.

Após uma rápida análise dos Balanços, inicial e final, observa-se que, mesmo com a reducão do Patrimônio Liquido e crescimento real do Passivo Exigivel, a empresa mantém, ainda, elevada liquidez e uma excelente alavancagem, como revelam seus indicadores financeiros. Seu Fluxo de Caixa mostra superávit, com boa disponibilidade de dinheiro ao longo desse mês.

Entretanto, o prejuizo auferido nesse período reflete, principalmente, o desempenho insatisfatório da atividade leiteira, cujo Valor Bruto da Produção cobre apenas 15\% dos elevados Custos Fixos da Pecuária, com destaque para o custo de oportunidade do pasto. Além disso, ressalta-se a significativa participacão das Depreciacões dentro do Custo dos Bens e Serviços Produzidos.

Como alternativa para melhorar o desempenho da Fazenda Bocaina pode-se sugerir, por exemplo, o incremento das vendas de animais (bezerros, novilhos, vacas descarte) e das prestacões de servicos, através do aluguel de equipamentos e implementos ociosos. 
Tabela 32. Ealanço Patrimonial

EMPRESA RURAL : FAZENDA BOCAINA

DATA: 01/01/91

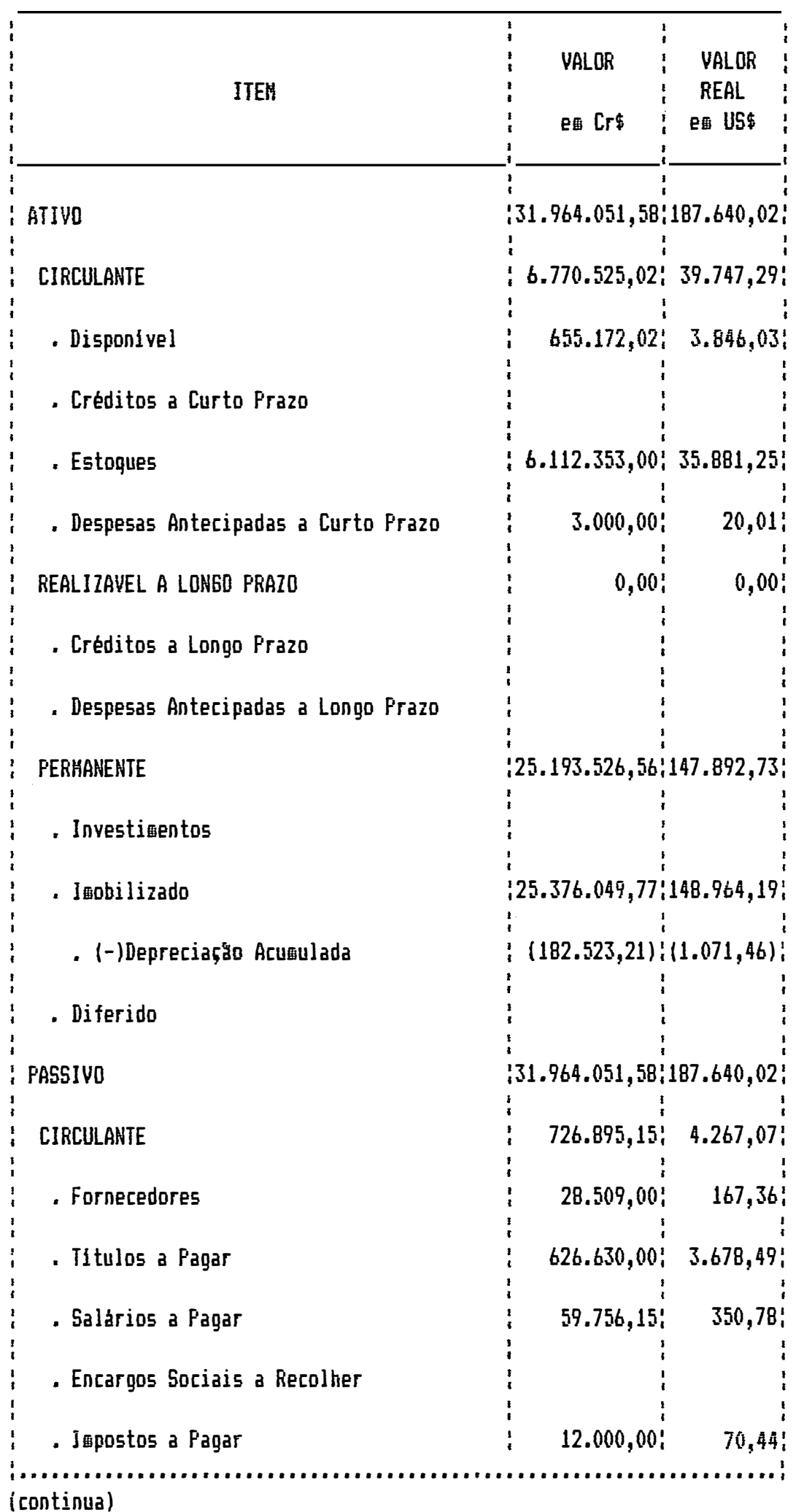


Tabela 32. Balanço Patrimonial (continuaçăo)

EMPFESA RULAL : FAZENDA BOCAINA

DATA: 01/01/91

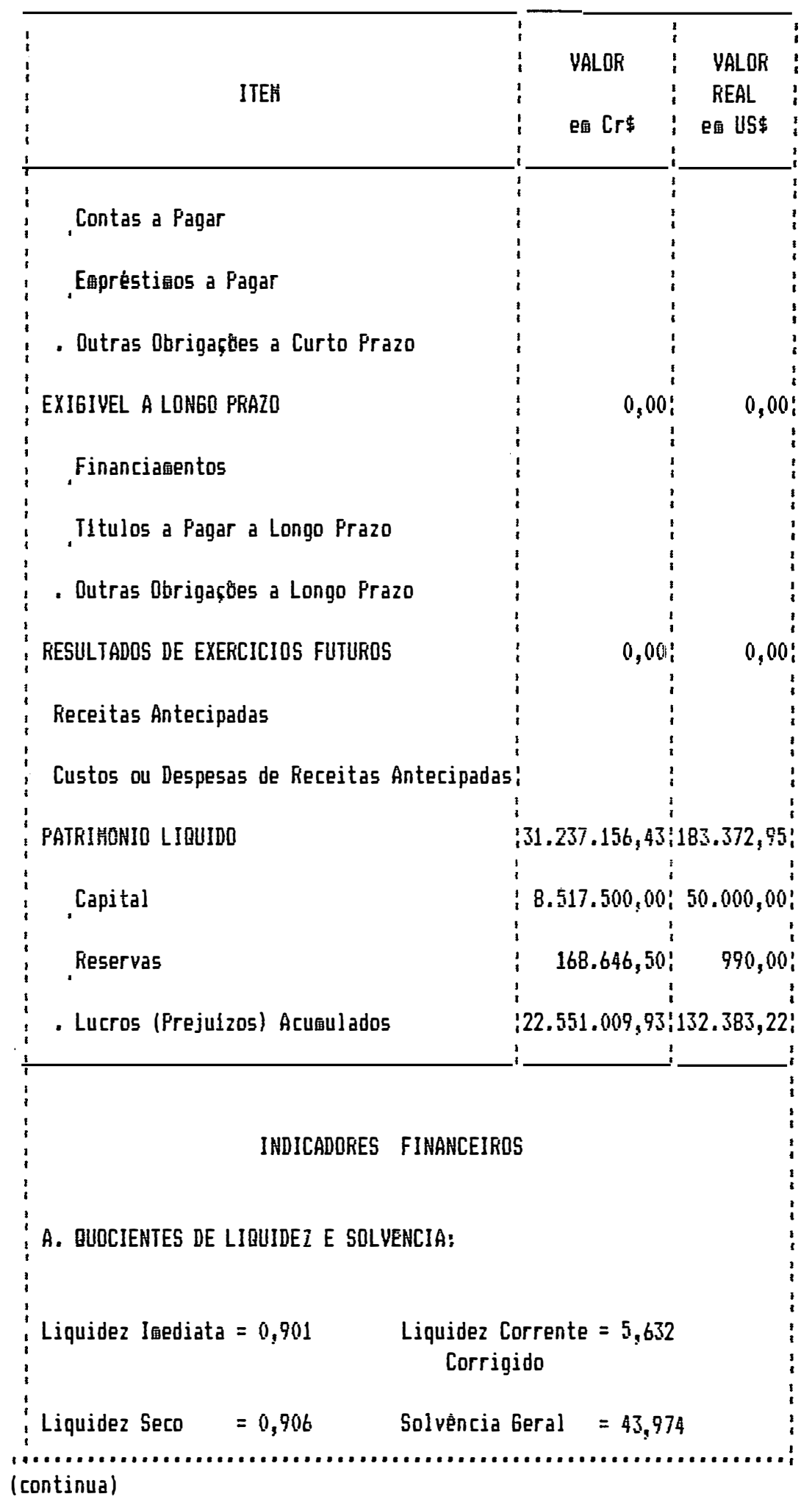


Tabela 32. Balanço Patrínonia) (continuaço)

EMFRESA RURAL : FAIENDA BOCAINA

DATA: $01 / 01 / 91$

'B. QUOCIENTES DE ENDIVIDAMENTO:

;

Participaçáo do

: Capital de $=0,023$

Terceiros

Participaçăo da

Divida de $=1,000$

Curto-Prazo

Alavanca Financeira $=0,023$

Todavia, é importante lembrar que um diagnóstico realista da performance da empresa deve partir, sempre, de uma análise meticulosa de todas as informações fornecidas pelos relatórios, complementadas por dados extracontábeis, como rendimentos operacionais, medidas de eficiencia produtiva e outros parâmetros técnicos. E preciso levar em conta, também, informacões de origem externa, uma vez que a empresa rural é um sistema aberto, em continua interação com o meio ambiente.

Antes de qualquer conclusão, entretanto, é imprescindivel que se tenha absoluta consciência do nivel de confiabilidade dos dados coletados, da capacidade do usuário compreender e utilizar, com eficiência, os recursos oferecidos pelo Modelo e de todas as limitacões intrínsecas a qualquer sistema contábil. 
Tabela 33. Detonstrą̧ăo do Resultado do Exercjcio da Etppresa e das Atividades fọrofecúárias

EMPRESA RURAL: FAIENDA BOCAINA

PERJODO: $01 / 12 / 90$ a $01 / 01 / 91$

DATA: $01 / 01 / 91$

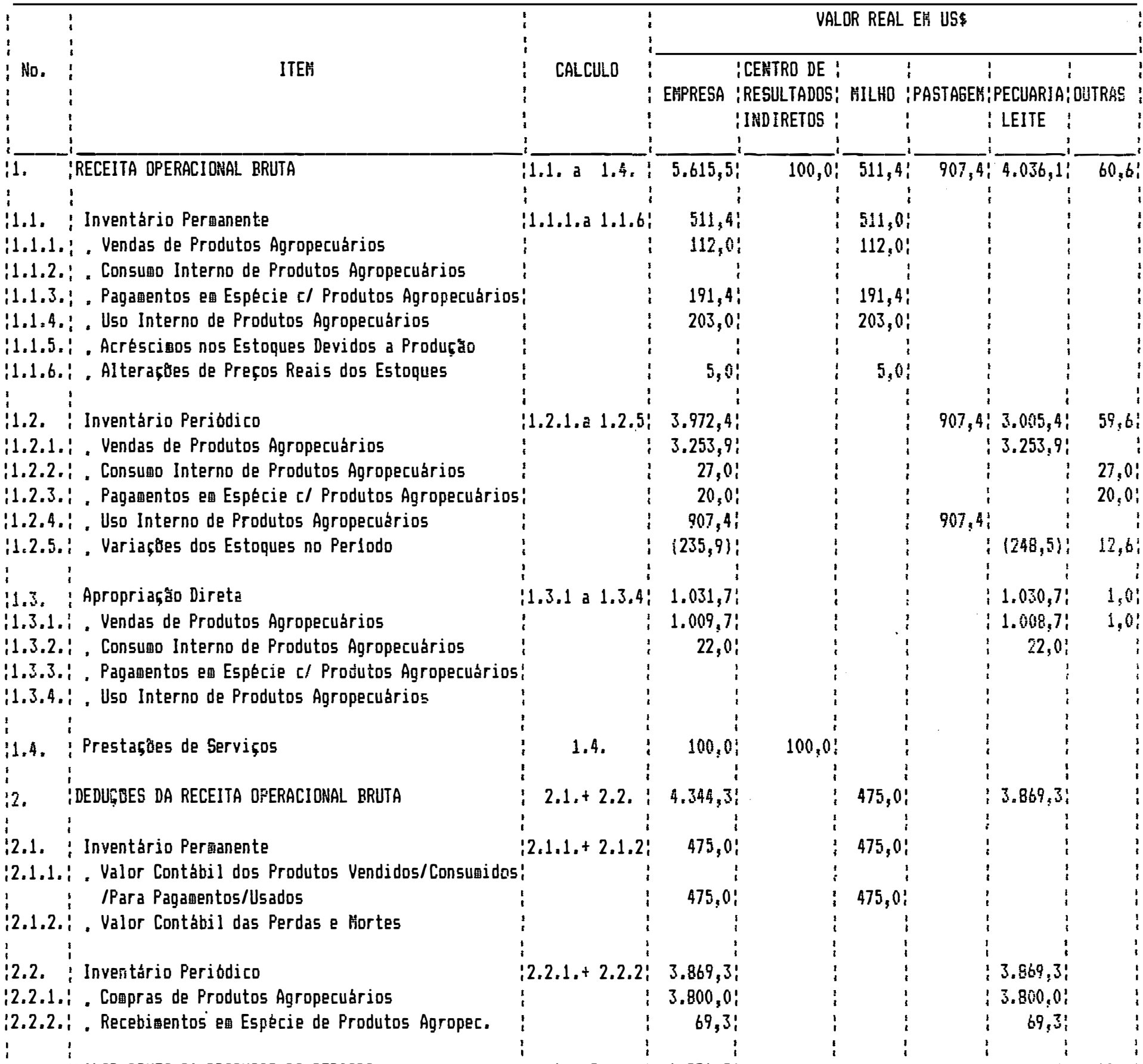

3. IVALOR BRUTO DA PRODUG,AD DO PERIODO


Tabela 33. (continuațăo)

\section{EMPRESA RURAL: FAZENDA BOCAINA}

PERIODO: 01/12/90 a 01/01/91

DATA: 01/01/91

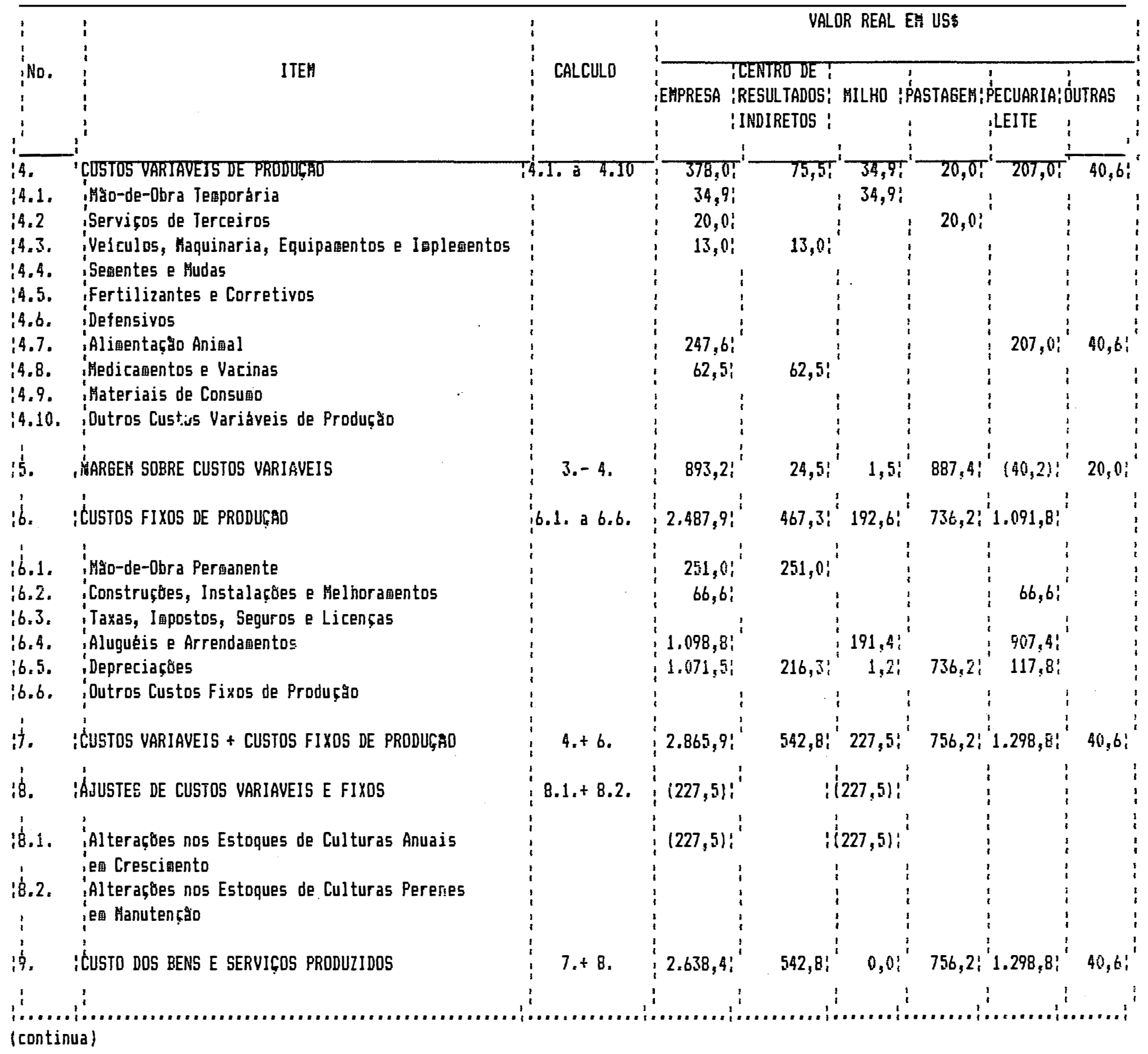


Tabela 33. (continuaço)

EMPRESA RURAL: FAZENDA BOCAINA

FERIODO: $01 / 12 / 90$ a 01/01/91

DATA: 01/01/91

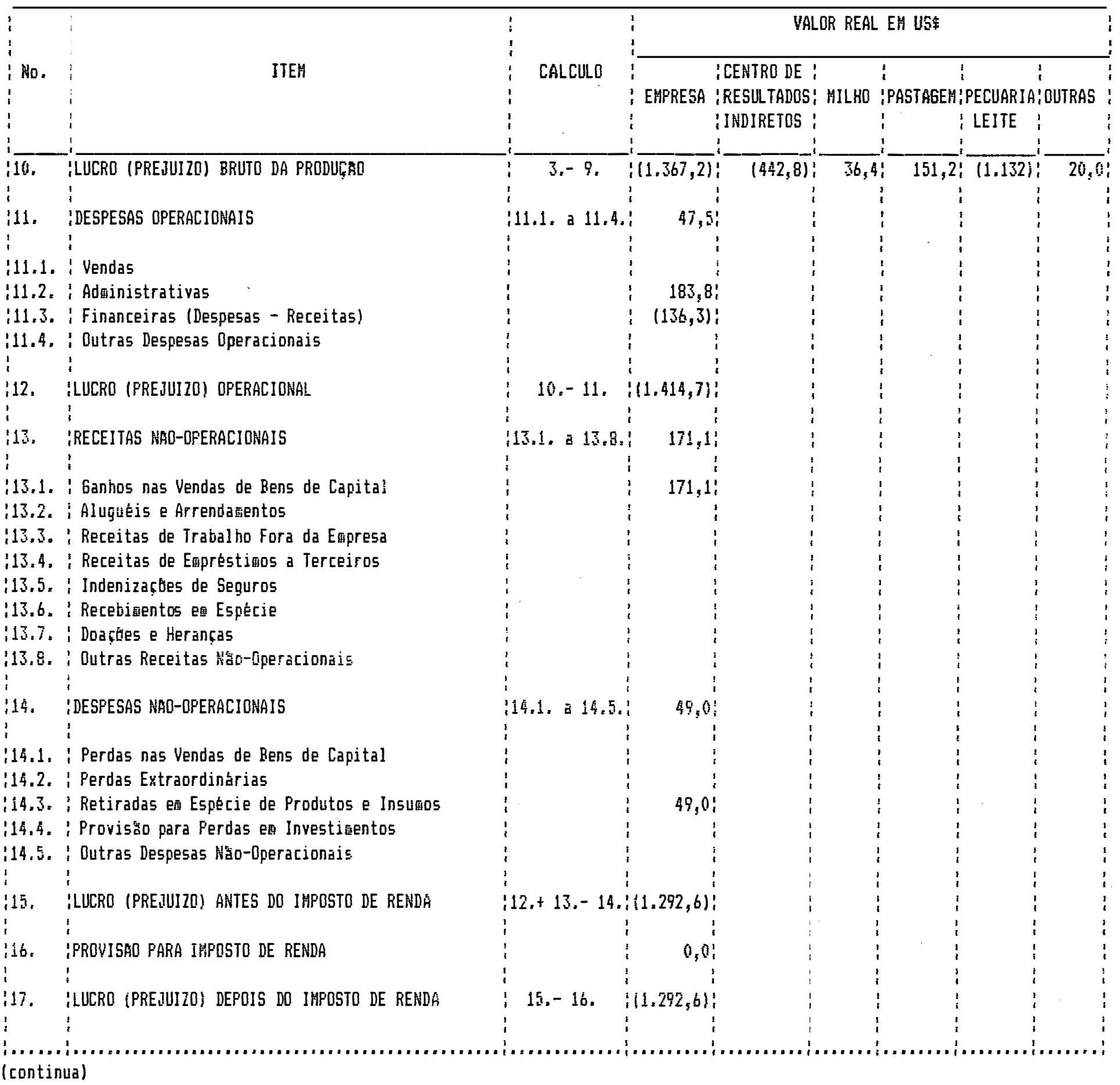


Tabela 33. (continuą̧ăo)

EHPRESA RURAL: FAZENDA BOCAINA

PERIODD: $01 / 12 / 90$ a $01 / 01 / 91$

DATA: $01 / 01 / 91$

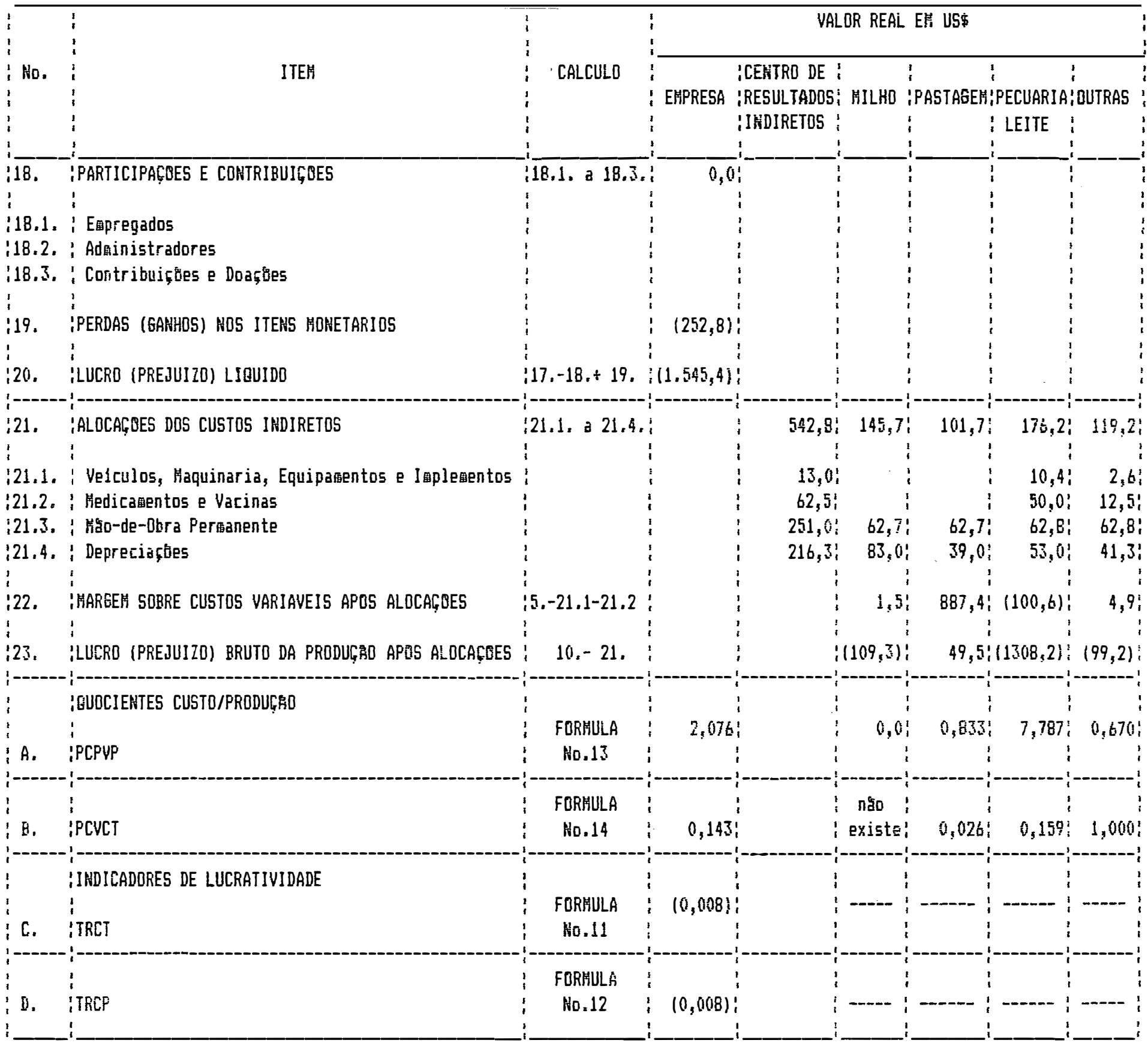


Tabela 34. Fluxo de Caixa

EMPRESA RURAL: FAZENDA BOCAINA

PERIODO: 01/12/90 a 01/01/91

DATA: 01/01/91

VALOR CORRENTE (E田 Cr\$)

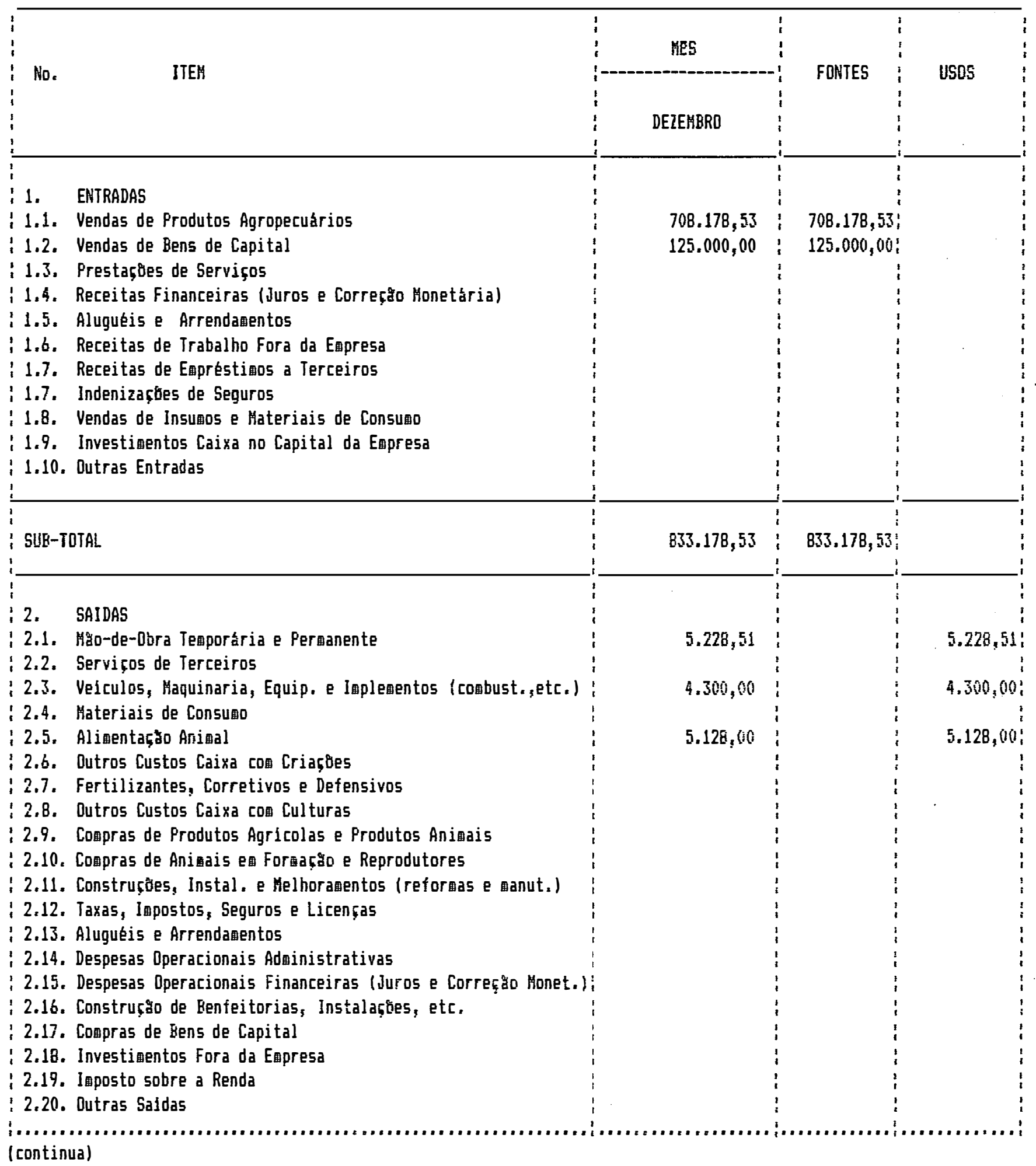


Tabela 34. Fluxo de Caina

EMPRESA RURAL: FAZENDA BOCAINA

PERIODO: 01/12/90 a 01/01/91

DATA: 01/01/91

VALOR CORRENTE (ERCT)

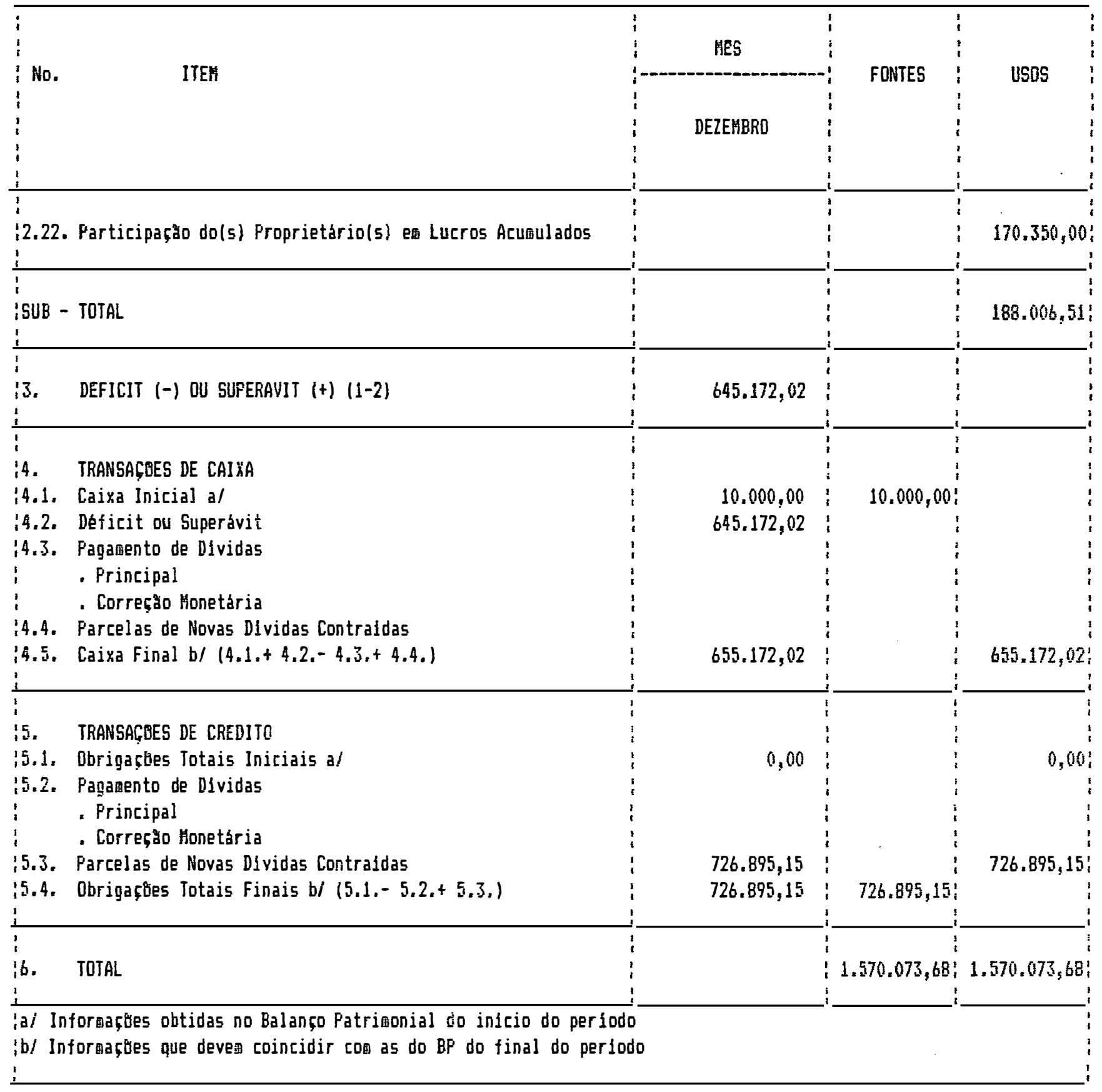


3.3.3. Conclusões sobre o Teste do Modelo Proposto

Após a aplicacão desse teste, fica evidente que a operacionalização manual do Método das Partidas Dobradas é bastante trabalhosa, não só pelo grande volume de registros, mas também pela quantidade de cálculos que devem ser realizados. Além do tempo considerável dispendido, a sua execução requer uma atencão redobrada do usuário para não cometer erros, muito frequentes nesse processo de escrituracão. Deve-se atentar, também, para o fato do empresário correr sérios riscos de não dispor das informacões, no momento esperado.

Recomenda-se, portanto, que o usuário do Modelo proposto evite a sua implementacão manual, a não ser em condicões particulares de pequenas empresas rurais, com poucas atividades e reduzido volume de transacões. Acredita-se que com a utilizacão do "software", a ser desenvolvido, as dificuldades impostas por esse Método serão realmente amenizadas.

Deve-se, contudo, ressaltar a validade desse teste manual que viabilizou a verificacão de cada etapa da metodologia desenvolvida, identificando a ocorrência de possiveis pontos de estrangulamento dentro do sistema. Observou-se, entre outras coisas que, embora trabalhoso, o consagrado Método das Partidas Dobradas é realmente insubstituivel quando se espera maior exatidão e riqueza de informacões.

Dentre as inovações incorporadas pelo Modelo, pôde-se averiguar a importância da geração de informações detalhadas por atividade produtiva e, ao mesmo tempo, da empresa como un todo, a 
possibilidade de se visualizar o verdadeiro intercâmbio econômico entre as diferentes explorąões e a relevância de um tratamento mais realista para o problema inflacionário. Acrescenta-se, a isso, a utilidade de princípios e conceitos, já mencionados e imprescindiveis para uma abordagem gerencial.

Finalmente, foi possivel constatar que, dentre as diversas alternativas existentes, para reger o funcionamento do sistema, as que foram escolhidas conferiram, ao Modelo proposto, as caracteristicas almejadas de maior capacidade informativa, confiabilidade e eficiência nos resultados. 
4. CONCLUSOES E RECOMENDAÇOES

O sucesso de qualquer empreendimento está subordinado à ut1l1ząão de um instrumental administrativo eficiente.

E justamente nesse aspecto que a empresa rural brasileira apresenta uma de suas mais visiveis carências, que coloca em risco todo o processo de modernização e crescimento de nossa agricultura.

Partindo dessa premissa, esta dissertacão teve como objetivo primordial desenvolver uma tecnologia voltada às necessidades gerenciais da empresa agropecuária brasileira: um Modelo de Contabilidade Rural.

O roteiro seguido teve como etapa inicial uma revisão critica dos principais modelos de Contabilidade Rural, existentes no Brasil e no exterior, avaliando a funcionalidade desses sistemas, sob a ótica gerencial. Ou seja, analisando suas informaç̃es, os procedimentos metodológicos adotados e conferindo - uso de princípios e convencões contábeis, na tentativa de desenvolver um material didático, que elucidasse algumas questões pendentes sobre o assunto.

Foi possivel constatar que, até o presente momento, a empresa rural brasileira não conta com o apoio de um sistema contábil eficiente, enquanto gerador de informações úteis às tomadas de decisões. Dentre os diferentes modelos revisados, com destaque para o trabalho pioneiro de MARION (1985a, 1985b, 1986), surgiu uma lacuna significativa, à medida que a atual crise 
econômica vem exigindo soluções para maior competitividade do setor agricola.

o resultado constituiu-se na proposicão de um Modelo que, conservando a estrutura já consagrada pela "Contabilidade Tradicional", incorporou conceitos fundamentais à análise econômica das atividades agropecuárias e elementos necessários à producão de informacões gerenciais confiáveis, dentro de um contexto inflacionário.

Um teste manual simplificado, com dados de uma pequena empresa, tentou demonstrar que o sistema proposto atende aos objetivos especificos dessa pesquisa e é suficientemente flexivel, para ser implementado em diferentes situacões.

Reconhece-se, no entanto, que o Modelo apresenta um certo grau de complexidade para seus usuários finais, particularmente o médio empresário rural. Entretanto, com a elaboração do "software", na segunda etapa deste projeto, acredita-se que essa nova metodologia possa ser difundida, de modo mais rápido e prático, entre os profissionais atuantes na área e, principalmente, que venha despertar o interesse da classe produtora.

Adicionalmente, espera-se que venha servir como referência para futuras pesquisas, sugerindo-se sistemas de registro da produção agropecuária, para o controle técnico de seus rendimentos operacionais e outras medidas de eficiência $e$, também, modelos de Contabilidade Rural por Partidas Simples. 
Finalmente, é importante ressaltar que este trabalho não teve, em nenhum momento, a pretensão de ser a panacéia da Contabilidade Rural. Sua verdadeira finalidade fol resgatar o Sistema Contábil como uma ferramenta imprescindivel à modernização do setor agricola brasileiro. 
REFERENCIAS BIBLIOGRAFICAS

ACARESC - Associąão de Crédito e Assistência Rural de Santa Catarina. Coordeną̧ão de Administracão Rural. Programa de gestão agricola. Florianópolis, SPG - ACARESC, 1986.

AITH, M. Mudancas no IR rural beneficiam a pessoa fisica. Gazeta Mercantil, São Paulo, 29 jan. 1991. Secão Legisląão, p.35.

ALBUQUERQUE, M.C.C. DE. O perfil do administrador rural: uma proposta curricular. Revista de Administracão de Empresas, Rio de Janeiro, 25 (4): 41-8, out./dez. 1985.

ALBUQUERQUE, M.C.C. DE, coord. Relatório do projeto de administracão rural. São Paulo, Fundacão do Desenvolvimento Administrativo, 1979 . $5 \mathrm{v}$.

ALOE, E. \& VALLE, F. Contabilidade agrícola. 2a. ed. São Paulo, Atlas, 1967. 240p.

ANGELICO, J. Contabilidade básica. 7a. ed. São Paulo, Atlas, 1982. 204P.

ARMBRUSTER, D.B. Introduction to agricultural accounting. Red Wing, Red Wing Business Systems, 1983. 135p.

AZEVEDO FILHO, A.J.B.V. A informática, o processo da tomada de decisão e o planejamento na agricultura. Piracicaba, ESALQ/ USP, 1984. 6p.

BARRY, P.J.; HOPKIN, J.A.; BAKER, C.B. Financial Management in Agriculture. 3a. ed. Illinois, The Interstate Printers \& Publishers, Inc., 1983. 491P.

BEMELMANS, P.F. O uso da contabilidade agrícola no estado de São Paulo. Agricultura em São Paulo, São Paulo, 15 (11/12): 4161, nov./dez. 1968.

BEMELMANS, P.F. Contabilidade agricola. Piracicaba, ESALQ/USP/ DESR, 1973. (Série didática, 33).

BEMELMANS, P.F. Análise dos rendimentos fisicos e económicos da empresa agropecuária. In: SEMINARIO NACIONAL DE ADMINISTRACAO DA EMPRESA AGROPECUARIA, 1., Curitiba, 1978. Anais. Curitiba, CEBRAE/PPTE, 1978. $58 \mathrm{p}$.

BEMELMANS, P.F. Métodos e técnicas de administrąão das empresas rurais. In: SEMINARIO DE MODERNIZACAO DA EMPRESA RURAL, 1., Rio de Janeiro, 1979. Anais. Brasilia, Binagri, 1979. v. 1., P. 63-7.

BIO, S.R. Sistemas de informacão: um enfoque gerencial. São Paulo, Atlas, 1985. 183p. 
BOEHLJE, M.D. \& EIDMAN, V.R. Farm management. New York, John Wiley \& Sons, 1984. 806 P.

BONETTI, M.A. Agricultura vai pagar mais imposto de renda em 91. O Estado de São Paulo, São Paulo, 28 mar. 1990. Suplemento Agricola, P.11.

BRANDT, S.A. \& OLIVEIRA, F.T.G. DE. Planejamento da nova empresa rural brasileira. Rio de Janeiro, Apec, 1973. 260 p.

BRANNEN, S.J. Contabilidade de custos no setor rural. In: SEMINARIO INTERNACIONAL DE ADMINISTRACAOO RURAL - Administração Contábil e Financeira na Empresa Agropecuária, 1., São Paulo, 1977. Anais. São Paulo, FUNDAP, 1979, 1v.

BURKE, T.J. Alguns problemas e possiveis rumos para a difusão de tecnologia gerencial entre produtores rurais. In: SEMINARIO NACIONAL DA ADMINISTRACAO DA EMPRESA AGROPECUARIA, 1., Curitiba, 1978. Anais. Curitiba, CEBRAE/PPTE, 1978.

CATI - Coordenadoria da Assistência Técnica Integral. Caderno de escriturạ̧ão agrícola. Campinas, CATI, 1980. 88p.

COPELAND, R.M.; DASCHER P.E.; DAVISON D.L. Financial Accounting. New York, John Wiley \& Sons, 1980. 517 P.

DELGADO, E. Experiência latino-americana em capacitação de administração rural, a nivel universitário, de pós-graduação e de produtores - Exame do sistema de capacitacão e sua articulação entre seus diferentes niveis. In: SEMINARIO DE MODERNIZACAO DA EMPRESA RURAL, 1., Rio de Janeiro, 1979. Anais. Brasilia, Binagri, 1979, v2., 252-58.

DIAS, W.F. O crédito rural e a contabilidade da empresa rural. In: SEMINARIO DE MODERNIZACAO DA EMPRESA RURAL, 1., Rio de Janeiro, 1979. Anais. Brasilia, Binagri, 1979. v.1, p. 226-7.

EMATER/RS - Empresa de Assistência Técnica e Extensão Rural do Rio Grande do Sul. Acompanhamento e análise técnico-econômicofinanceira da propriedade rural. Porto Alegre, COPER-UNICREA, 1987. 1v.

ESCOLA SUPERIOR DE AGRICULTURA "LUIZ DE QUEIROZ", Piracicaba. COMISSAO DE POS-GRADUAÇAO. Normas para a elaboração de dissertações e teses. Piracicaba, 1987. 64p.

ETTORI, O.J.T. Contabilidade agropecuária. 2a. ed. São Paulo, Editora dos Criadores, 1976. 244p.

FRANCO JUNIOR, C.F. Contabilidade agricola: Uma análise histórica e empirica para o sudoeste brasileiro. Piracicaba, 1984. 128p. (Mestrado - Escola Superior de Agricultura "Luiz de Queiroz"/USP). 
FREY, T.L. \& KLINIFELTER, D.A. Coordinated finanolal otatements for agriculture. Illinois, Agri Finance, 1978. 82p.

FROGOLI, L.E. Sistema contábil de informações. In: SEMINARIO INTERNACIONAL DE ADMINISTRAÇAO RURAL - Administrạ̧ão Contábil e Financeira na Empresa Agropecuária, 1., São Paulo, 1977. Ana1s. São Paulo, FUNDAP, 1979. 1v.

FUNDACAO DO DESENVOLVIMENTO ADMINISTRATIVO. Bibliografia de administracão rural. São Paulo, 1978. 104p.

GALVAO, A. Contabilidade agrícola global. 2a. ed. Lisboa, Fundação Calouste Gulbenkian, 1967. 265p.

GASTAL, E.F. Administração rural - planejamento a nivel de unidade de produção. In: SEMINARIO DE MODERNIZACAO DA EMPRESA RURAL, 1., Rio de Janeiro, 1979. Anais. Brasilia, Binagri, 1979. v.1., p. 111-123.

GARCIA, A.R. Plano elimina incentivos fiscais. Folha de São Paulo, São Paulo, 27 mar. 1990. Agrofolha.

GARCIA, A.R. Novo IR rural obriga produtor a se organizar. 0 Estado de São Paulo, São Paulo, 30 jan. 1991. Suplemento Agricola, P.11.

GOUVEIA,N. Contabilidade. 2a. ed. São Paulo, McGraw-Hill, 1982. 627p.

HOFFMANN, R. A evolução da desigualdade da distribuição da posse da terra no Brasil no período de 1960 a 1980. Reforma Agrária, 12 (6): 17-35, 1982.

HOFFMANN, R.; ENGLER, J.J. DE C.; SERRANO, O.; THAME, A.C. DE M.; NEVES, E.M. Administrạão da empresa agrícola. São Paulo, Pioneira, 1976. 323p.

IUDICIBUS, S. DE. Análise de balanços. 4a. ed. São Paulo, Atlas, 1982. 250p.

IUDICIBUS, S. DE, coord. Contabilidade introdutória. 6a. ed. Săo Paulo, Atlas, 1983. 300p.

IR agrícola terá BTN como base de cálculo. Folha de São Paulo, São Paulo, 07 de jan. 1991. Caderno de Economia, p.B-4.

IR-Atividades rurais-Apuração e tributação de resultadosAlteraç̃es. IOB - Textos Legais, São Paulo, p.430-431, dez. 1990 .

JAMES, S.C. \& STONEBERG, E. Farm accounting and business analysis. 2a. ed. Iowa, The Iowa State University Press, 1980. 271p. 
JAMES, S.C. \& STONEBERG, E. Farm accounting and business analysis. 3a. ed. Iowa, The Iowa State University Press, 1986. $312 \mathrm{P}$.

LEE, W.F.; BOEHLJE, M.D.; NELSON, A.G.; MURRAY, W.G. Agricultural Finance. 7a. ed. Iowa, The Iowa State University Press, 1980. 437p.

LEITE, H. DE P. Contabilidade para administradores. São Paulo, Atlas, 1988. $2 \mathrm{v}$.

MARION, J.C. Contabilidade da pecuária. 2a. ed. São Paulo, Atlas, 1985a. 181p.

MARION, J.C. Contabilidade rural. São Paulo, Atlas, 1985 b. $222 p$.

MARION, J.C. Contabilidade empresarial. 3a. ed. São Paulo, Atlas, 1986. 540p.

MARTINS, E. Contabilidade de custos. 3a. ed. São Paulo, Atlas, 1987. 357p.

MATTOS, Z.P. DE B.; NORONHA, J.F. DE; MARQUES, P.V. Introdução à administração rural. Piracicaba, ESALQ/USP/DESR, 1986. 205p.

MATTOS, Z.P. DE B.; DUARTE, L.P.; NORONHA, C.M.S. Fluxo de Caixa - Manual do Usuário do Projeto de Aplicacão de Microcomputador pela Extensão Rural na Assistência ao Agricultor. Piracicaba, ESALQ/USP/DESR, 1988. 19p.

NETTO, B.L. Experiência em capacitacão de recursos humanos para - setor rural - Transferência de tecnologia administrativa através da assistência técnica e extensão rural. In: SEMINARIO DE MODERNIZAÇO DA EMPRESA RURAL, 1., Rio de Janeiro, 1979. Anais. Brasilia, Binagri, 1979. v.2, p, 282336.

NOBRE, E.R. Necessidade da contabilidade e da escrituracão na agricultura. Coopercotia, Så Paulo, (140): 16-17, Jun. 1961.

NORONHA, J.F. DE. Projetos agropecuários - Administracão financeira, orcamento e viabilidade econômica. 2a. ed. São Paulo, Atlas, 1987. 270p.

NORONHA, J.F. DE. Informática na agricultura. Piracicaba, ESALQ/USP/FEALQ/DESR.

OLIVEIRA, J.A. DE. A contabilidade rural como instrumento de decisão gerencial. In: SEMINARIO DE MODERNIZACAO DA EMPRESA RURAL, 1., Rio de Janeiro, 1979. Anais. Brasilia, Binagri, 1979. v1, p. 111-23. 
PENSON, J.R. \& NIXON, C.J. Undergtandine finanolal statements in agriculture. Texas, College Station, Agri-Information Corporation, 1983. 121p.

PENSON, J.R. \& NIXON, C.J. How to analyze financial statements in agriculture. College Station, Texas, Agri-Information Corporation, 1985. 61p.

RECEITA divulga regras do IR para agricultor. Folha de São Paulo, São Paulo, 19 jan. 1991. Caderno de Economia, p.B-8.

RIBEIRO, J.P. Plano de administracão da propriedade rural como veículo da modernização da agricultura. Brasilia, EMBRATER, 1985. 58p. (Série Leituras Selecionadas, 14).

SANTOS, A.M. \& ANDRADE, J.G. Atividades essenciais para administrąão da empresa rural. In: CONGRESSO DE ECONOMIA E SOCIOLOGIA RURAL, 20., Curitiba, 1982. Anais. Curitiba, SOBER, 1982. P. 175-80.

SAO PAULO. Instrução Normativa No.138, de 28 de Dezembro de 1990. Diário Oficial da República Federativa do Brasil, Brasília-DF, 31 de dez. 1990. Sęão I, p.25782. Dispõe sobre a tributąão dos resultados da atividade rural (Lei no.8.023/90).

SCOTT, J. Análise das demonstrạ̃̃es financeiras. In: SEMINARIO INTERNACIONAL DE ADMINISTRACAO RURAL-ADMINISTRACAO CONTABIL E FINANCEIRA NA EMPRESA AGROPECUARIA, 1., São Paulo, 1977. Anais. São Paulo, FUNDAP, 1979. 1v.

SILVA, J.L. Curso de contabilidade agrícola. Vicosa, UFV/Departamento de Economia Rural, 1971. 112p.

TEIXEIRA, E.C.; MOURA, L.M. DE; RIBON, M. Escriturą̧ão da empresa rural. 2a. ed. Vicosa, UFV, 1981. 51p.

TEIXEIRA FILHO, A.R. Análise e avaliação das pesquisas em administração rural e economia da produção no Brasil. In: SEMINARIO DA SOBER, 10., Brasilia, 1972. Anais. São Paulo, SOBER, 1974. P. 13-36.

VALLE, F. Manual de contabilidade agricola. São Paulo, Atlas, 1983. 284p. 